\title{
AVALIAÇÃO DAS ALTERAÇÕES DENTOESQUELÉTICAS DECORRENTES DO TRATAMENTO DA MÁ OCLUSÃO DE CLASSE II, SUBDIVISÃO POR MEIO DAS RADIOGRAFIAS SUBMENTONIANA E PÓSTERO-ANTERIOR
}

\section{KARINA SANTANA CRUZ}

Dissertação apresentada à Faculdade de Odontologia de Bauru, da Universidade de São Paulo, como parte dos requisitos para obtenção do título de Mestre em Odontologia, área de Ortodontia. 


\title{
AVALIAÇÃO DAS ALTERAÇÕES DENTOESQUELÉTICAS DECORRENTES DO TRATAMENTO DA MÁ OCLUSÃO DE CLASSE II, SUBDIVISÃO POR MEIO DAS RADIOGRAFIAS SUBMENTONIANA E PÓSTERO-ANTERIOR
}

\section{KARINA SANTANA CRUZ}

\author{
Dissertação apresentada à Faculdade de \\ Odontologia de Bauru, da Universidade de São \\ Paulo, como parte dos requisitos para obtenção do \\ título de Mestre em Odontologia, área de \\ Ortodontia.
}

(Edição Revista)

Orientador: Prof. Dr. Guilherme R. P. Janson. 
CRUZ, Karina Santana

Avaliação das alterações dentoesqueléticas C889a decorrentes do tratamento da má oclusão de Classe II, subdivisão por meio das radiografias submentoniana e póstero-anterior / Karina Santana Cruz. - Bauru, 2000.

208p. mais apêndices: il.; $30 \mathrm{~cm}$

Dissertação. (Mestrado) - Faculdade de Odontologia de

Bauru. USP.

Orientador: Prof. Dr. Guilherme R. P. Janson.

Autorizo, exclusivamente para fins acadêmicos e científicos, a reprodução total ou parcial desta dissertação, por processos fotocopiadores e/ou meios eletrônicos.

Assinatura do autor (a):

Data: 


\section{KARI NA SANTANA CRUZ}

23 de Fevereiro de 1972

Aracaju-SE

1990-1994

1995-1997

1997-1999

$1998-2000$

ASSOCIAÇÕES
Nascimento

Curso de Graduação pela Universidade Federal de Sergipe.

Curso de Aperfeiçoamento em Ortodontia pela APCD Regional - Bauru.

Curso de Especialização em Ortodontia e Ortopedia Facial pela Faculdade de Odontologia de Bauru-USP.

Curso de Pós-graduação em Ortodontia, em nível de Mestrado, na Faculdade de Odontologia de Bauru, Universidade de São Paulo.

ABO - Associação Brasileira de Odontologia.

SPO - Sociedade Paulista de Ortodontia.

WFO - World Federation of Orthodontics. 


\section{Dedicatória}

Aos meus queridos pa is,

\section{JORGE RESENDE CRUZ e}

\section{MARI A HELENA SANTANA CRUZ}

pelo amor incondicional, a poio e incentivo irrestritos, em benefício da minha formação humana e profissional, sempre compreendendo meus ideais de vida e torcendo para que meus objetivos se concretizassem, duran te tod o o tempo.

A DEUS, por me fortalecer di a n te dos obstá culos en con tra dos n esta caminhada.

Minha eterna gratidão!!! 


\section{Meu profundo a feto}

Ao meu irmão, Jorge Flávio, pelo a poio, carinho e incentivo consta n tes.

À minha irmã Kátia, e aos meus sobrinhos, Gabriel Marcel e Pedro Jorge, pelo carinho e estímulo sempre presentes.

Ao meu tio Marcos, pela sua luta incansável em prol dos interesses da classe odontológica, a lém do a poi o e da a mizade constantes.

Aos meus tios, padrinhos e madrinhas João Antônio, Gilza e Tereza, pelas pala vras de conforto que sempre me brindaram. 


\section{Meu reconhecimento e admiração}

Ao Professor Doutor

\section{GUI LHERME DOS REI S PEREI RA J ANSON,}

Pela orientação criteriosa, rigor científico, a poio e incentivos constantes. Sobretudo, pela disponibilidade nas orientações quanto à obten ção das radiografias, utilização da Análise Estatística e do Erro do Método, a spectos fundamentais para a maior precisão da metodologia deste trabalho. Além da amizade e oportunidade em compartilhar conhecimentos transmitidos ao longo desta jornada, contribuindo para o aprofundamento da minha qualificação profissional. 


\section{Agradecimentos Especiais}

Ao Prof. Dr. José Fernando Castanha Henriques, Professor Titular e Coordenador do Curso de Pós-Graduação em Ortodontia, em nível de Doutorado, pelo incentivo profissional, pelas orientações e amizade transmitida, durante toda a minha trajetória acadêmica em Bauru.

Ao Coordenador do Curso de Pós-Graduação em Ortodontia, em nível de Mestrado e Chefe de Departamento, Prof. Dr. Marcos Roberto de Freitas, pelos ensinamentos e amizade transmitida.

Aos demais Professores do Departamento de Ortodontia, Prof. Dr. Arnaldo Pinzan, Prof. Dr. Décio Rodrigues Martins, Prof. Dr. Eduardo Alvares Dainesi, Prof. Dr. Renato Rodrigues de Almeida, pela valiosa contribuição para minha formação profissional.

À Prof ${ }^{a}$ Dr $^{\mathrm{a}}$ Izabel Maria Marchi de Carvalho, responsável pelo Setor de Radiologia do Hospital de Reabilitação de Lesões Labiopalatais, por ter permitido a utilização dos aparelhos de raios $\mathrm{X}$, para a obtenção das radiografias. Agradeço também ao Dr. Carlos Alberto Carvalho Pires, aos radiologistas, funcionários e residentes deste Setor, pelas orientações na utilização dos aparelhos e auxílio prestados.

Ao Prof. Dr. José Alberto de Souza Freitas, pela oportunidade em utilizar as dependências do Hospital de Reabilitação de Bauru.

Ao Prof. José Roberto Lauris, pelos esclarecimentos estatísticos.

Aos colegas e amigos do Curso de Mestrado em Ortodontia, Ana Carla Nahás, Ana Cláudia Conti, Daniela Garib, Danilo Siqueira, Fausto Bramante, Karyna Valle, Paulo Carvalho, Renata Almeida e Roberto Bombonatti pela convivência agradável e laços de amizade. 
Aos colegas do Doutorado, Acácio Fiuzy, Alexandre Moro, Liliana Brangeli, Márcio Almeida, Maria Helena Vasconcelos e Ricardo Takahashi pelo convívio e amizade.

Aos colegas do Curso de Especialização, pelos momentos de confraternização, além do convívio agradável.

Aos antigos colegas da Pós-graduação, Eduardo Dainesi, Graziela Canto, Jorge Toruño, Letícia Souza, Márcia Kawauchi, Pedro Paulo Gondim, pela amizade, atenção e cordialidade.

Aos colegas de Aracaju, Alaíde Oliveira, André Lucas, Anuska Nunes, Carlos Neanes, Candice Bittencourt, Lafaiete Brandão, Luciano Pacheco e Rosa Bragança, pelos laços de amizade e bons momentos de convivência em Bauru.

À grande amiga Valéria Barbosa, pelas palavras de conforto e apoio nos momentos mais difíceis.

À amiga Ivone Pinto e família, pela atenção e cordialidade.

Ao Guilherme Janson, uma pessoa singular, pelos momentos agradáveis e pelo encorajamento incessante, motivando-me na busca do saber. 


\section{Agradeco ainda}

Aos funcionários do Departamento de Ortodontia, Vera Lúcia Purgato, Maria José Formenti, Tereza Cristina Camaforte, Cristiane Cano e Luís Sérgio Vieira, pela colaboração e amizade.

Aos funcionários da ACOPEN, Sônia Pinzan, Simone Del Rio e César Formenti, pela cordialidade com que sempre me receberam.

Aos funcionários da biblioteca, pela atenção e serviços prestados.

Ao Prof. Valdir Afonso, pela revisão gramatical.

Aos técnicos Daniel Rascão Selmo e Josué Amancio, pela colaboração em vários aspectos do campo da informática.

Aos pacientes que muito contribuíram para o meu enriquecimento profissional.

A todos aqueles que me proporcionaram contribuições diretas e indiretas para o meu desenvolvimento profissional e pessoal.

\section{Agradecimentos Administrativos}

Ao Prof. Dr. Aymar Pavarini, Diretor da Faculdade de Odontologia de Bauru - USP.

Ao Prof. Dr. Luís Fernando Pegoraro, Presidente da Comissão de Pós-Graduação da Faculdade de Odontologia de Bauru - USP.

À Fundação de Amparo à Pesquisa do Estado de São Paulo (FAPESP), pela concessão da bolsa de estudo. 


\section{SUMÁRIO}

LISTA DE FIGURAS .............................................................................................iii

LISTA DE TABELAS ......................................................................................

RESUMO_..............................................................................................................

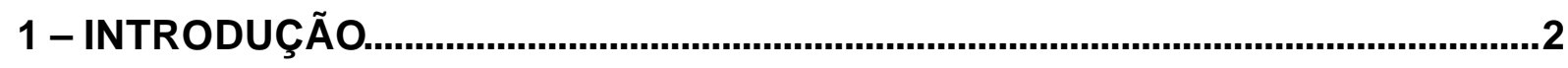

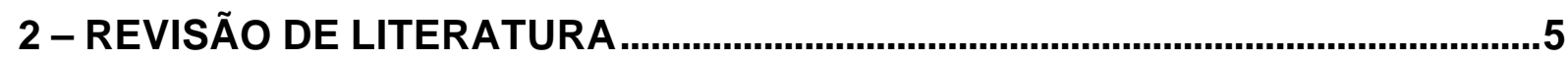

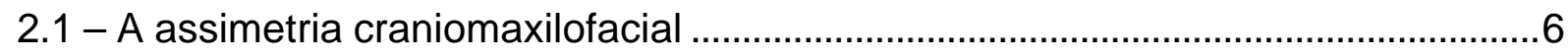

2.2 - O desenvolvimento da assimetria craniomaxilofacial e a oclusão dentária .......14

2.3 - Fatores etiológicos determinantes da assimetria dentofacial ...............................21

2.4 - A Classe II, subdivisão e sua relação com a assimetria …………………...........27

2.5 - Métodos de diagnóstico das más oclusões de Classe II, subdivisão....................34

2.6 - Modalidades de tratamento da Classe II, subdivisão ............................................53

2.6.1 - Tratamento ortopédico funcional da Classe II, subdivisão............................55

2.6.2 - Tratamento ortodôntico corretivo da Classe II, subdivisão ............................60

2.6.2.1 - Mecânicas assimétricas empregadas na correção da Classe II,

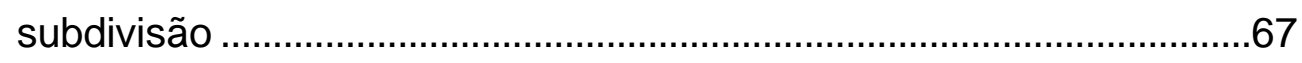

2.6.2.2 - Correção das discrepâncias de linha média ........................................71

2.6.3 - Tratamento combinado ortodôntico-cirúrgico da Classe II, subdivisão .......82

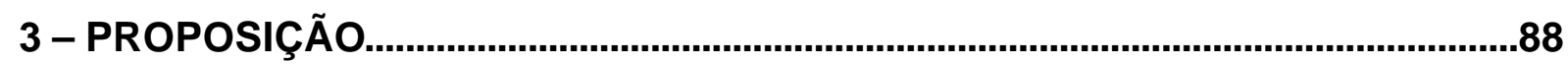

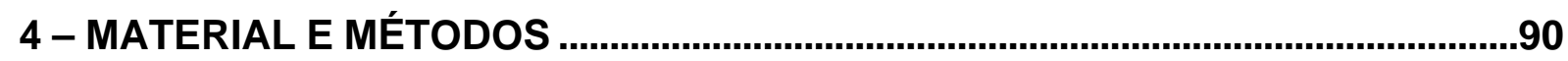

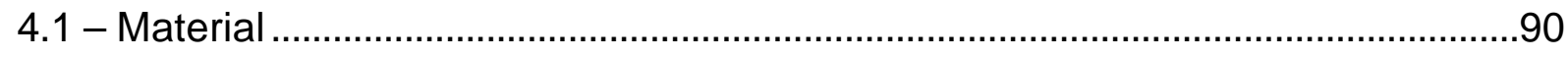

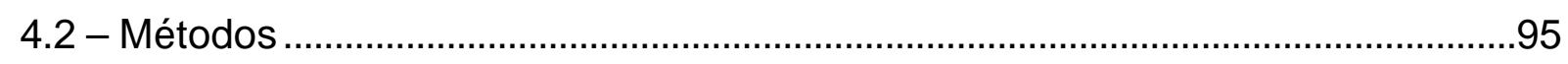

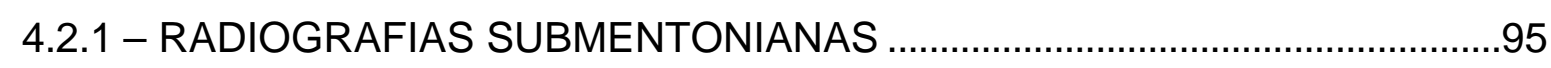

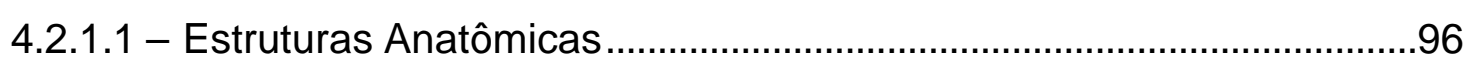

4.2.1.2 - Pontos de Referência .......................................................................96

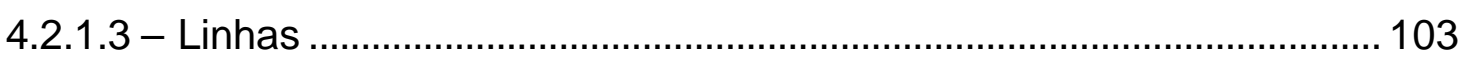

4.2.1.4 - Grandezas Cefalométricas........................................................... 105 
4.2.1.4.1 - Sistemas de Coordenadas Mandibulares. 106

4.2.1.4.1.1 - Ântero-posterior .................................................................... 106

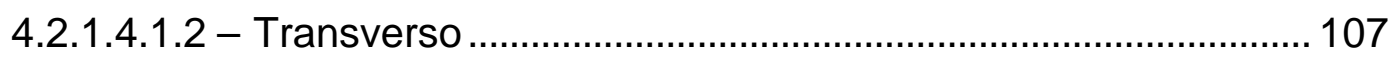

4.2.1.4.2 - Sistema de Coordenadas do Assoalho Craniano ...................... 107

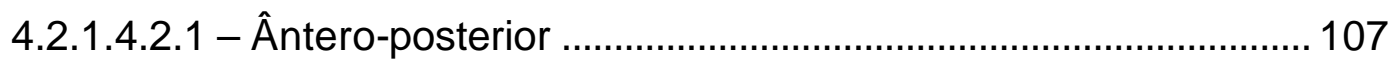

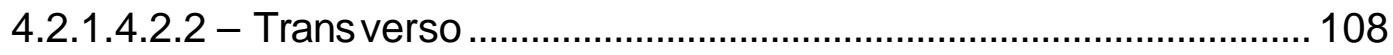

4.2.1.4.3 - Sistema de Coordenadas do Complexo Zigomaticomaxilar ... 113

4.2.1.4.3.1 - Ântero-posterior ................................................................... 113

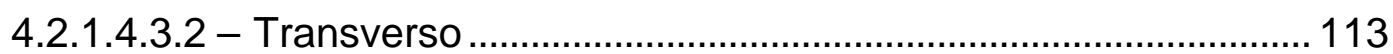

4.2.1.4.4 - Sistema de Coordenadas Dentárias .......................................... 113

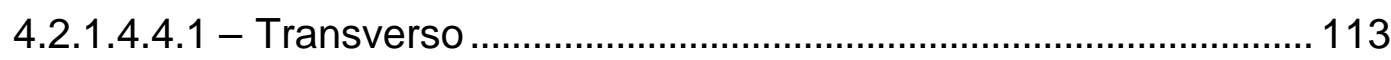

4.2.1.4.5 - Medidas Angulares entre as abscissas dos sistemas de coordenadas ........................................................................ 114

4.2.1.4.6 - Variáveis Adicionais .................................................................. 114

4.2.1.4.7 - Diferenças entre as medidas bilaterais ..................................... 115

4.2.1.4.7.1 - Coordenadas Mandibulares .................................................... 115

4.2.1.4.7.1.1 - Ântero-posterior .............................................................. 115

4.2.1.4.7.1.2 - Transverso .................................................................... 115

4.2.1.4.7.2 - Coordenadas do Assoalho Craniano ................................... 115

4.2.1.4.7.2.1 - Ântero-posterior ................................................................... 115

4.2.1.4.7.2.2 - Transverso .................................................................... 115

4.2.1.4.7.3 - Complexo Zigomaticomaxilar ............................................... 116

4.2.1.4.7.3.1 - Ântero-posterior .............................................................. 116

4.2.1.4.7.3.2 - Transverso ............................................................................ 116

4.2.1.4.7.4 - Variáveis Adicionais ..............................................................116

4.2.2. - RADIOGRAFIAS PÓSTERO-ANTERIORES …........................................ 122

4.2.2.1 - Estruturas Anatômicas ....................................................................... 122

4.2.2.2 - Pontos de Referência ........................................................................ 123

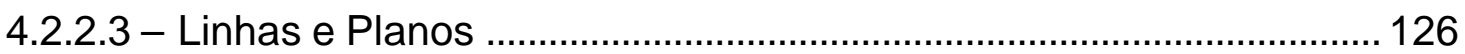

4.2.2.4 - Grandezas Cefalométricas.............................................................. 126

4.2.2.4.1 - Diferenças entre as medidas bilaterais ..................................... 129

4.2.3 - Análise Estatística................................................................................... 135 
4.2.3.1 - Erro do Método ........................................................................... 135

4.2.3.2 - Comparações entre os grupos ...................................................... 135

5 - RESULTADOS

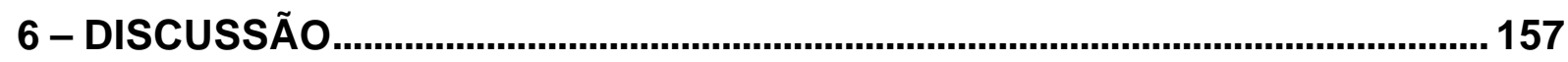

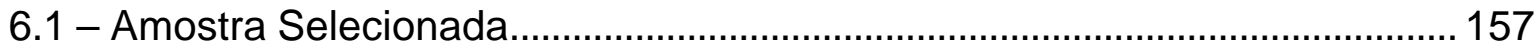

6.2 - Metodologia Empregada ……………………....................................... 160

6.3 - Considerações sobre a Mensuração das Grandezas Cefalométricas ........ 161

6.4 - Precisão da Metodologia............................................................................ 162

6.5 -Resultados Obtidos nas Radiografias Submentonianas ......................... 164

6.5.1 - Sistema de Coordenadas Mandibulares ................................................. 165

6.5.1 - Sistema de Coordenadas do Assoalho Craniano .................................. 169

6.5.2 - Sistema de Coordenadas Zigomaticomaxilares..................................... 170

6.5.3 - Sistema de Coordenadas Dentárias ....................................................... 172

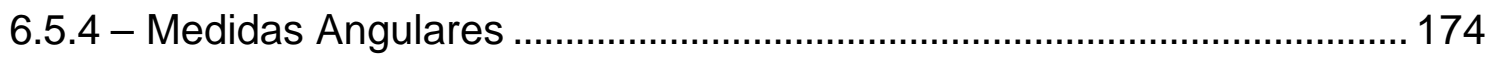

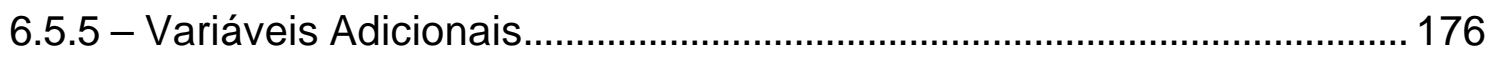

6.6-Resultados Obtidos nas Radiografias Póstero-Anteriores ..................... 177

6.7 - Considerações clínicas sobre o tratamento da Classe II, subdivisão. 179

6.7.1 - Considerações clínicas quanto às abordagens de tratamento empregadas nos casos de Classe II, subdivisão deste trabalho. 181

6.7.2 - Sugestões para Futuras Pesquisas 184

7 - CONCLUSÕES

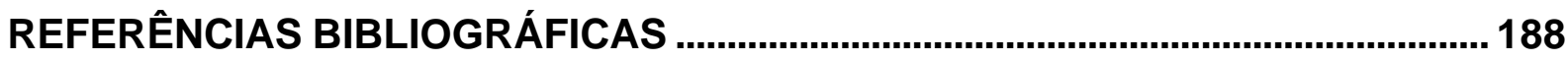

ABSTRACT

APÊNDICES 


\section{LISTA DE FIGURAS}

FIGURA 4.A1 - Vista frontal - Caso de Classe II, subdivisão, pré-tratamento . .93

FIGURA 4.A2 - Vista lateral direita - Caso de Classe II, subdivisão, prétratamento

FIGURA 4.A3 - Vista lateral esquerda - Caso de Classe II, subdivisão, prétratamento

FIGURA 4.A4 - Vista frontal - Caso de Classe II, subdivisão, tratado com extração de apenas um pré-molar superior

FIGURA 4.A5 - Vista lateral direita - Caso de Classe II, subdivisão, tratado com extração de apenas um pré-molar superior

FIGURA 4.A6 - Vista frontal - Caso de Classe II, subdivisão, tratado com extração de apenas um pré-molar superior

FIGURA 4.B1 - Vista frontal - Caso de Classe II, subdivisão, pré-tratamento 94

FIGURA 4.B2 - Vista lateral direita - Caso de Classe II, subdivisão, prétratamento

FIGURA 4.B3 - Vista lateral esquerda - Caso de Classe II, subdivisão, prétratamento

FIGURA 4.B4 - Vista frontal - Caso de Classe II, subdivisão, tratado com extrações de três pré-molares

FIGURA 4.B5 - Vista lateral direita - Caso de Classe II, subdivisão, tratado com extrações de três pré-molares

FIGURA 4.B6 - Vista frontal - Caso de Classe II, subdivisão, tratado com extrações de três pré-molares

FIGURA 4.1 - Estruturas Anatômicas da Radiografia Submentoniana 101

FIGURA 4.2 - Pontos de Referência da Radiografia Submentoniana 102

FIGURA 4.3 - Linhas da Radiografia Submentoniana 104

FIGURA 4.4 - Grandezas Cefalométricas da Radiografia Submentoniana Sistema de Coordenadas Mandibulares - Ântero-posterior 109

FIGURA 4.5 - Grandezas Cefalométricas da Radiografia Submentoniana Sistema de Coordenadas Mandibulares - Transverso 
FIGURA 4.6 - Grandezas Cefalométricas da Radiografia Submentoniana Sistema de Coordenadas do Assoalho Craniano - Ânteroposterior

FIGURA 4.7 - Grandezas Cefalométricas da Radiografia Submentoniana Sistema de Coordenadas do Assoalho Craniano - Transverso ..... 112

FIGURA 4.8 - Grandezas Cefalométricas da Radiografia Submentoniana Sistema de Coordenadas do Complexo Zigomaticomaxilar Ântero-posterior

FIGURA 4.9 - Grandezas Cefalométricas da Radiografia Submentoniana Sistema de Coordenadas do Complexo Zigomaticomaxilar Transverso

FIGURA 4.10 - Grandezas Cefalométricas da Radiografia Submentoniana -

Sistema de Coordenadas Dentárias - Transverso

FIGURA 4.11 - Grandezas Cefalométricas da Radiografia Submentoniana Medidas Angulares entre as Abscissas dos Sistemas de Coordenadas

FIGURA 4.12 - Grandezas Cefalométricas da Radiografia Submentoniana Variáveis Adicionais

FIGURA 4.13 - Estruturas Anatômicas da Radiografia Póstero-Anterior 130

FIGURA 4.14 - Pontos de Referência da Radiografia Póstero-Anterior 131

FIGURA 4.15 - Linhas e Planos da Radiografia Póstero-Anterior

FIGURA 4.16 - Grandezas Angulares da Radiografia Póstero-Anterior

FIGURA 4.17 - Grandezas Lineares da Radiografia Póstero-Anterior.

FIGURA 6.1- Médias das variáveis que apresentaram diferenças estatisticamente significantes no Sistema de Coordenadas Mandibulares, no sentido ântero-posterior

FIGURA 6.2 - Médias das variáveis que apresentaram diferenças estatisticamente significantes no Sistema de Coordenadas do Assoalho Craniano, nos sentidos ântero-posterior e transverso .... 170

FIGURA 6.3- Médias das variáveis que apresentaram diferenças estatisticamente significantes no Sistema de Coordenadas Zigomaticomaxilares, nos sentidos ântero-posterior e transverso . 171 
FIGURA 6.4 - Médias das variáveis do Sistema de Coordenadas Dentárias, no sentido transverso

FIGURA 6.5 - Médias das medidas angulares que apresentaram diferenças estatisticamente significantes ..........................................................176

FIGURA 6.6 - Médias dos valores absolutos das variáveis adicionais ................... 177

FIGURA 6.7 - Médias dos valores absolutos das variáveis que apresentaram diferenças estatisticamente significantes, na Radiografia

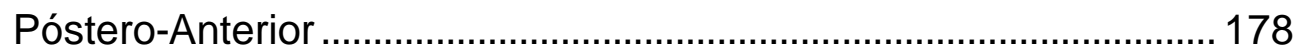




\section{LISTA DE TABELAS}

Médias reais e desvios padrão das variáveis

TABELA 1 - Sistema de Coordenadas Mandibulares ................................................ 138

TABELA 2 - Sistema de Coordenadas do Assoalho Craniano .................................... 139

TABELA 3 - Sistema de Coordenadas Zigomaticomaxilares .................................... 139

TABELA 4 - Sistema de Coordenadas Dentárias........................................................ 139

TABELA 5 - Medidas Angulares ………………………..................................... 140

TABELA 6 - Variáveis Adicionais ...................................................................... 140

TABELA 7 - Radiografia Póstero-Anterior............................................................... 140

Análise intra-examinador: apresentação dos erros casuais (DAHLBERG ${ }^{37}$ ), das médias, dos desvios padrão (D.P.) das diferenças e do nível de significância estatística dos erros sistemáticos (p), entre os pares dos traçados repetidos

TABELA 8 - Sistema de Coordenadas Mandibulares ................................................ 141

TABELA 9 - Sistema de Coordenadas do Assoalho Craniano ................................... 141

TABELA 10 - Sistema de Coordenadas Zigomaticomaxilares ................................. 142

TABELA 11 - Sistema de Coordenadas Dentárias................................................... 142

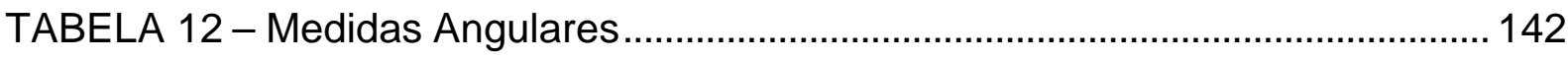

TABELA 13 - Variáveis Adicionais .......................................................................... 143

TABELA 14 - Radiografia Póstero-Anterior ............................................................. 143

Resultados do teste $t$ independente, entre os grupos de oclusão normal e de Classe II, subdivisão, não tratado (JANSON ${ }^{73}$ ) (Grupo 3 x Grupo 1)

TABELA 15 - Sistema de Coordenadas Mandibulares.............................................. 144

TABELA 16 - Sistema de Coordenadas do Assoalho Craniano ............................... 144

TABELA 17 - Sistema de Coordenadas Zigomaticomaxilares ................................... 145

TABELA 18 - Sistema de Coordenadas Dentárias.................................................... 145

TABELA 19 - Medidas Angulares....................................................................... 145

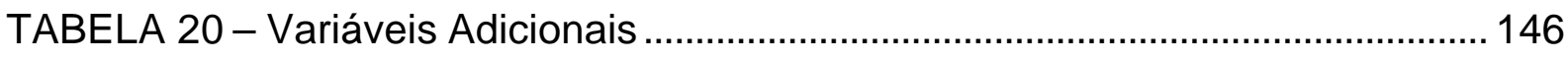

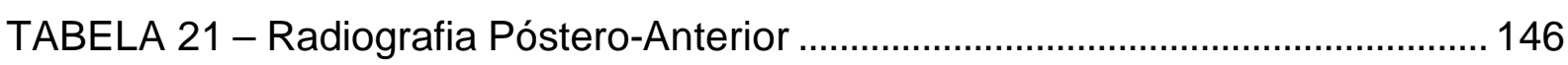


Resultados do teste $t$ independente, entre os grupos de oclusão normal e de Classe II, subdivisão, tratado com extrações assimétricas (Grupo 3 x Grupo 2)

TABELA 22 - Sistema de Coordenadas Mandibulares. 147

TABELA 23 - Sistema de Coordenadas do Assoalho Craniano 147

TABELA 24 - Sistema de Coordenadas Zigomaticomaxilares ................................... 148

TABELA 25 - Sistema de Coordenadas Dentárias..................................................... 148

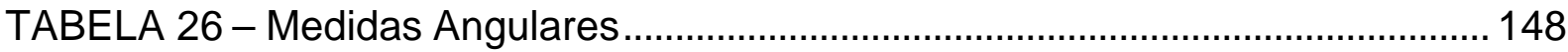

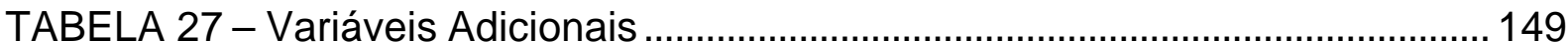

TABELA 28 - Radiografia Póstero-Anterior ............................................................ 149

Resultados do teste $t$ independente, entre os grupos de oclusão normal e de Classe II, subdivisão, tratado com extração de apenas um pré-molar superior (Grupo 3 x Subgrupo A)

TABELA 29 - Sistema de Coordenadas Mandibulares............................................. 150

TABELA 30 - Sistema de Coordenadas do Assoalho Craniano ................................. 150

TABELA 31 - Sistema de Coordenadas Zigomaticomaxilares ................................. 151

TABELA 32 - Sistema de Coordenadas Dentárias.................................................... 151

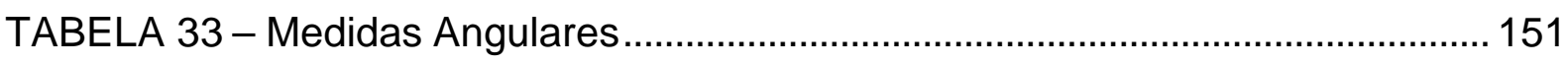

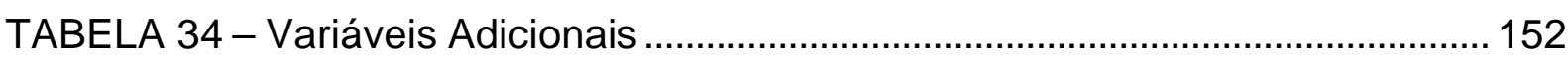

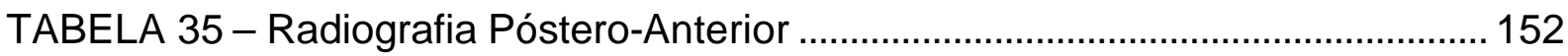

Resultados do teste $t$ independente, entre os grupos de oclusão normal e de Classe II, subdivisão, tratado com extrações de três pré-molares (Grupo 3 x Subgrupo B)

TABELA 36 - Sistema de Coordenadas Mandibulares............................................ 153

TABELA 37 - Sistema de Coordenadas do Assoalho Craniano ................................. 153

TABELA 38 - Sistema de Coordenadas Zigomaticomaxilares .................................. 154

TABELA 39 - Sistema de Coordenadas Dentárias................................................... 154

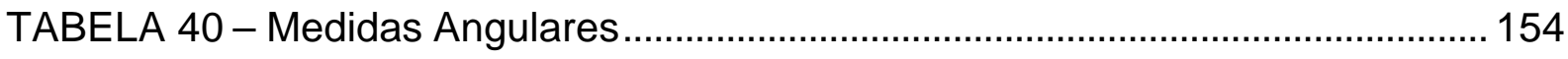

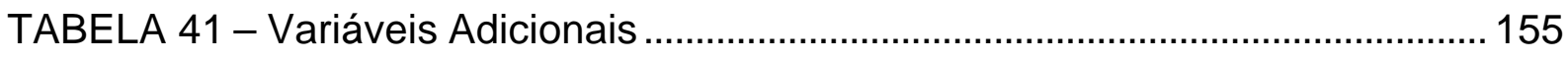

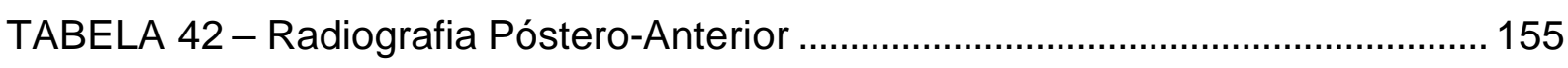




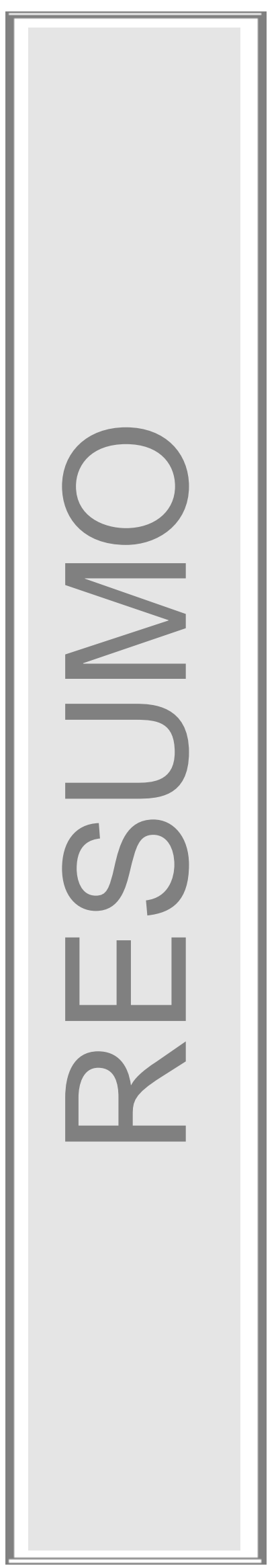




\section{RESUMO}

objetivo deste trabalho foi avaliar as alterações dentoesqueléticas decorrentes do tratamento ortodôntico com extrações assimétricas de pacientes com má oclusão de Classe II, subdivisão de Angle, em relação a um grupo controle de oclusão normal. A amostra consistiu de três grupos, com 30 pacientes cada, apresentando as seguintes características: grupo 1 - jovens com Classe II, subdivisão, não tratados; grupo 2 - jovens com Classe II, subdivisão, tratados com extrações assimétricas; grupo 3 - jovens com oclusão normal. Todos apresentavam os dentes permanentes superiores e inferiores, em ambos os arcos dentários, até os primeiros molares, no início do tratamento. A idade média da amostra foi de 15,76, 18,57 e 22,42 anos nos grupos de Classe II, subdivisão não tratado, Classe II, subdivisão tratado e oclusão normal, respectivamente. Medidas de diferenças relativas da posição espacial de pontos dentários e esqueléticos bilaterais foram obtidas nas radiografias submentoniana e póstero-anterior. $\mathrm{O}$ teste $\mathrm{t}$ para amostras independentes foi utilizado para comparar os grupos 1 e 2 com o grupo 3, em tempos diferentes. Considerou-se que o grupo 2 tinha apresentado uma melhora se as variáveis do grupo 1, que tiveram uma diferença estatisticamente significante com o grupo 3, não fossem estatisticamente diferentes do grupo com oclusão normal. Os resultados nas radiografias submentonianas demonstraram que as extrações assimétricas nas más oclusões de Classe II, subdivisão acentuaram as diferenças nas posições ântero-posteriores direita e esquerda, dos primeiros molares superiores e inferiores, como esperado com estes protocolos de extrações. Não houve alterações esqueléticas significantes que pudessem ser atribuídas às formas de tratamento investigadas e nem efeitos colaterais transversais com as mecânicas assimétricas empregadas. Também foi demonstrado que o tratamento da Classe II subdivisão com extrações assimétricas normaliza o posicionamento das linhas médias superior e inferior sem causar inclinação do plano oclusal ou de qualquer outro plano horizontal pesquisado, na análise da radiografia póstero-anterior. Portanto, concluiu-se que o tratamento da Classe II, subdivisão com extrações assimétricas constitui uma modalidade terapêutica válida para a solução deste problema. 


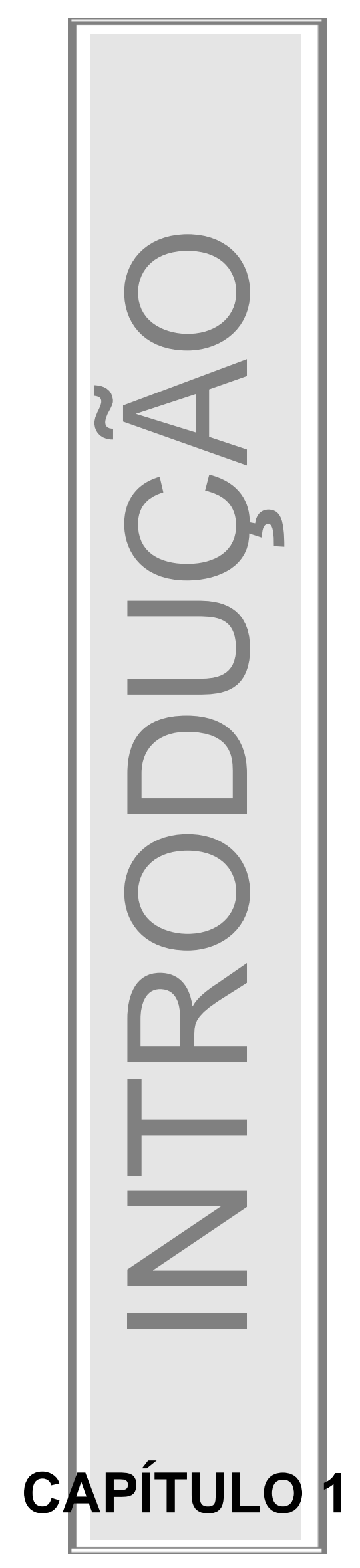




\section{1 - INTRODUÇÃO}

$$
\begin{aligned}
& \text { E 1988, ALAVI; BEGOLE; SCHNEIDER }{ }^{1} \text { verificaram que a Classe II, } \\
& \text { subdivisão resultaria principalmente de uma assimetria de posição }
\end{aligned}
$$
dos molares inferiores, embora não tenham discriminado se a origem do problema seria dentária, esquelética ou uma combinação de ambas as caracte rísticas. ROSE et al. ${ }^{137}$, em 1994, confirmaram que a Classe II, subdivisão era geralmente causada pela posição mais posterior do molar inferior, no lado da Classe II, do que no lado da Classe I. Mais tarde, JANSON ${ }^{73}$, em 1998, concluiu que os componentes mais freqüentes que contribuem para a relação ântero-posterior assimétrica na Classe II, subdivisão eram dentoalveolares, sendo que a principal diferença entre a má oclusão de Classe II, subdivisão e a oclusão normal consistiu numa posição mais para distal do primeiro molar inferior do lado da Classe II, em uma base óssea com assimetria normal. Uma diferença secundária consistiu na posição mais para mesial do primeiro molar superior, no lado da Classe II. Verificou-se também que $50 \%$ das más oclusões de Classe II constituem-se em subdivisões ${ }^{3,169}$.

Baseando-se nos resultados obtidos nestes trabalhos ${ }^{1,73,137}$, concluiurse que em grande parte dos casos de Classe II, subdivisão, a linha média dentária superior apresenta-se coincidente, ou com um mínimo desvio e a linha média dentária inferior se apresenta deslocada para o lado da Classe II, ambas em relação ao plano sagital mediano, devido à posição mais posterior do molar deste lado, em faces apresentando uma assimetria subclínica ${ }^{34}$. Nestes casos, uma das melhores opções de tratamento consiste na extração de dois pré-molares superiores e de um pré-

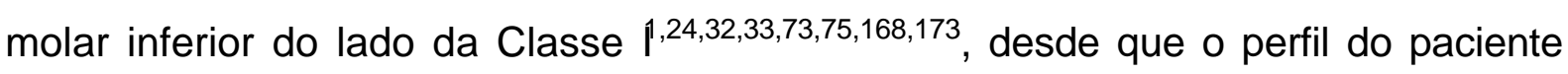
permita certa retração dos incisivos superiores e inferiores. Uma outra combinação de má oclusão de Classe II, subdivisão, que ocorre com menor freqüência e também evidenciada nestes estudos, consiste naquela em que há desvio da linha média dentária superior em relação ao plano sagital mediano e coincidência da linha média dentária inferior, em relação a esse plano, em casos sem apinhamento superior ou inferior $^{73}$. Nestes casos, os melhores resultados são proporcionados pela extração 
de apenas um pré-molar superior do lado da Classe $\mathbb{1}^{73,173}$. Entretanto, existem especulações ${ }^{24,25,41,131}$ de que estas formas de tratamento podem causar efeitos colaterais dentoalveolares indesejáveis, principalmente no plano frontal. Portanto, este trabalho objetivou estudar as alterações ocasionadas por esses dois protocolos de extrações, em relação a um grupo de oclusão normal, no tratamento da Classe II subdivisão, visando elucidar essas questões persistentes. 


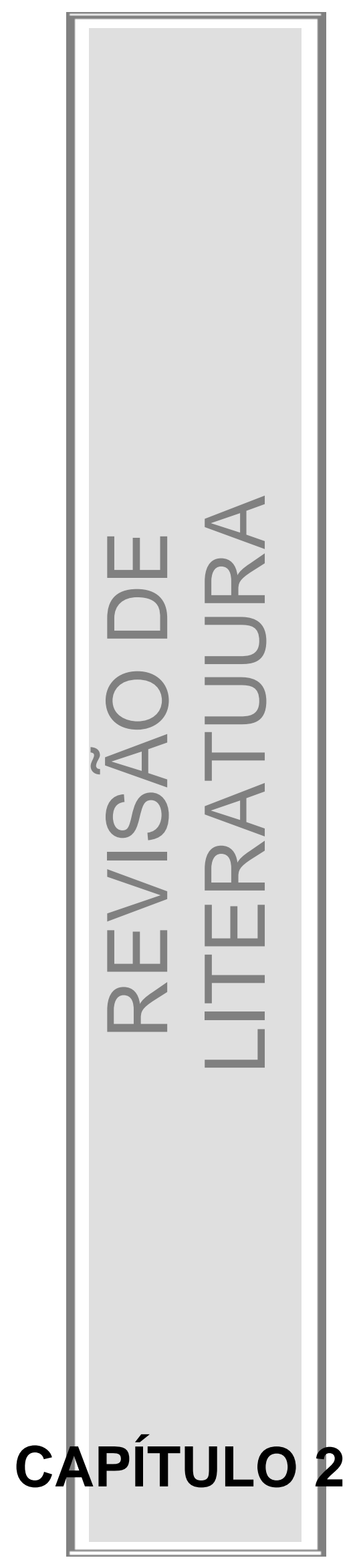




\section{2 - REVISÃO DE LITERATURA}

isando uma melhor interpretação dos resultados deste estudo e de suas principais implicações clínicas, este capítulo revisa a literatura concernente ao assunto desta pesquisa, de acordo com a seqüência de tópicos descritos a seguir:

2.1 - A assimetria craniomaxilofacial;

2.2 - O desenvolvimento da assimetria craniomaxilofacial e a oclusão dentária;

2.3 - Fatores etiológicos determinantes da assimetria dentofacial;

2.4 - A Classe II, subdivisão e sua relação com a assimetria;

2.5 - Métodos de diagnóstico das más oclusões de Classe II, subdivisão;

2.6 - Modalidades de tratamento da Classe II, subdivisão;

2.6.1 - Tratamento ortopédico funcional da Classe II, subdivisão;

2.6.2 - Tratamento ortodôntico corretivo da Classe II, subdivisão;

2.6.2.1 - Mecânicas assimétricas empregadas na correção da Classe II, subdivisão;

2.6.2.2 - Correção das discrepâncias de linha média,

2.6.3 - Tratamento combinado ortodôntico-cirúrgico da Classe II, subdivisão. 


\section{1 - A assimetria craniomaxilofacial}

A assimetria facial constitui-se num dos maiores problemas para os ortodontistas, pois apresenta um difícil diagnóstico. O reconhecimento da severidade da assimetria torna-se essencial no correto plano de tratamento. A assimetria ocorre em presença de um ou mais componentes cranianos ou faciais bilaterais (tecidos moles e ossos) não eqüidistantes da linha média ou quando o centro de cada estrutura ímpar não coincide com esta linha ${ }^{96}$. As assimetrias das estruturas craniofaciais podem ter efeitos secundários na dentição e na oclusão, podendo apresentar problemas clínicos maiores associados, quando são do tipo severo. As fissuras labiopalatais constituem-se num exemplo disto, porém existem muitas outras assimetrias craniofaciais que podem causar conseqüências dentárias, como as anomalias de desenvolvimento, patologias, traumatismos e iatrogenias ${ }^{34}$.

Analisando 63 medidas de cada um dos 800 crânios egípcios estudados, $W^{182}$, em 1931, verificou que os ossos do crânio do lado direito exibiam uma assimetria, denotando que este lado demonstrava um maior tamanho conseqüente ao maior desenvolvimento do hemisfério cerebral direito. O kdo contralateral do complexo facial exibia uma maior assimetria, apresentando um maior tamanho na região do arco zigomático e da hemimaxila esquerda, apesar do terço inferior do esqueleto facial não ter sido investigado.

Em 1932, LUDWIG ${ }^{94}$ citou em sua monografia que os destros apresentam-se numa freqüência de $95 \%$ e os sinistros em aproximadamente $5 \%$, na civilização humana. Para cada caso, há uma tendência de se utilizar o lado direito ou esquerdo do corpo, sugerindo que uma assimetria do sistema nervoso central faz-se presente. Para confirmar esta premissa, afirmou que o centro da fala situa-se no hemisfério cerebral esquerdo nas pessoas destras e no direito, nas sinistras. Quanto ao aspecto morfológico, as diferenças entre os lados direito e esquerdo se refletem no comprimento dos braços e das pernas; o braço direito geralmente é mais longo que o esquerdo e a perna direita mais curta que a esquerda. Desta forma, a assimetria 
sistemática consiste num fenômeno comum, mesmo em relação às partes do corpo que se assemelham essencialmente em estrutura em cada lado.

Estudando 149 crânios adultos do Peru, BJÖRK; BJÖRK ${ }^{17}$, em 1964, verificaram que a deformação occipital usualmente resultava em um menor tamanho da base do crânio no lado mais deformado, posicionando a cavidade glenóide mais anteriormente deste mesmo lado. Concluíram que a linha média facial não desenvolve uma assimetria de maneira análoga à base do crânio porque o crescimento maxilomandibular é inferior, no lado deformado. Este efeito, de acordo com estes autores, referiu-se a uma assimetria compensatória dos maxilares, diferentemente da assimetria displásica que promove uma hipo ou hiperplasia unilateral do côndilo mandibular.

Utilizando um sistema de medição ortogonal nos traçados das radiografias lateral e póstero-anterior, MULICK ${ }^{114}$, em 1965, estudou a assimetria craniofacial em seis conjuntos de trigêmeos. Pareando-se os trigêmeos de cada conjunto entre si, obtiveram-se seis pares de gêmeos idênticos e 12 pares de gêmeos fraternos. Os trigêmeos eram leucodermas, com idade entre 9 a 15 anos. As radiografias desta amostra foram obtidas em duas épocas distintas e separadas por um intervalo de três anos. Os dados obtidos permitiram a análise das diferenças entre os gêmeos idênticos e fraternos, entre os grupos com idades diferentes, entre os períodos de observação diferentes e entre as distintas regiões do complexo craniofacial. Para a análise estatística dos resultados, utilizou a análise de variância multifatorial. Os resultados demonstraram que não houve diferença significante entre os grupos de gêmeos idênticos e fraternos, concluindo-se que a hereditariedade não se constitui num fator regulador na produção da assimetria craniofacial, excetuando-se as síndromes hereditárias. O autor estabeleceu também variações de assimetria para os diversos pontos utilizados neste estudo. A avaliação transversal mostrou que existem diferenças significantes na quantidade de assimetria das várias regiões e pontos craniofaciais, enquanto que a avaliação longitudinal não mostrou diferenças significantes. Desta forma, embora inicialmente possam haver diferenças entre os lados direito e esquerdo, essas diferenças não se intensificam com as alterações 
dimensionais que ocorrem com a idade. Apesar de existirem diferenças, de acordo com a idade, na média de assimetria no sentido transversal, não há efeito da idade na assimetria média individual quando analisada longitudinalmente. $O$ autor estabeleceu também variações de assimetria para os diversos pontos utilizados neste estudo.

Diversas variáveis existentes na face foram demonstradas por ENLOW; KURODA; LEWIS ${ }^{40}$, em 1971. Estes autores afirmaram que uma alteração em alguma porção do complexo craniofacial produz uma alteração igual em outra parte e, algumas vezes, em sentido contrário. Devido à habilidade intrínseca individual para compensar alterações de crescimento regionais, uma alteração relevante em uma parte anatômica não impede necessariamente 0 desenvolvimento de proporções faciais harmoniosas.

As mensurações do esqueleto craniofacial em humanos, em crânios ou em radiografias cefalométricas costumam ser comumente utilizadas no estudo do crescimento e desenvolvimento facial, das bases apicais e dos arcos dentários. VIG; HEWITT $^{172}$, em 1975, desenvolveram uma metodologia para a análise da assimetria facial, comparando-se os lados direito e esquerdo, por meio de radiografias pósteroanteriores. Desta forma, os 63 jovens selecionados não poderiam apresentar nenhum grau de assimetria e nem desarranjos dentários. A faixa etária desta amostra variou entre 9 a 18 anos, com idade média de 14 anos, sendo que 20 jovens eram do sexo masculino e 43 do sexo feminino. Após a realização dos traçados cefalométricos, concluíram que as regiões da base do crânio e da maxila exibiam uma assimetria predominantemente maior do lado esquerdo, enquanto a mandíbula e as regiões dentoalveolares apresentavam um maior grau de simetria.

Avaliando a assimetria do complexo craniofacial normal, $\mathrm{SHAH}$; JOSHI ${ }^{151}$, em 1978, selecionaram 43 jovens clinicamente. A amostra constava de 29 pacientes do sexo masculino e 14 do sexo feminino, com idade média de 21 anos e seis meses. Para este estudo, utilizaram radiografias póstero-anteriores de pacientes com os dentes em oclusão cêntrica apresentando faces simétricas clinicamente e oclusão 
normal. Concluíram que a assimetria da face pode estar presente mesmo se os dentes apresentam um excelente contato oclusal, máxima intercuspidação e linhas médias dentárias superiores e inferiores coincidentes. Além disso, verificaram que as estruturas da face são significantemente maiores no lado direito do que no lado esquerdo e que uma das possíveis causas para a produção da assimetria relacionava-se ao hábito de mastigação unilateral. Como as forças mastigatórias são transmitidas aos dentes para os ossos do crânio e da face, estes autores observaram que a maioria dos jovens mastigava mais do lado direito do que do lado esquerdo, constituindo-se num dos possíveis fatores responsáveis pelo lado direito ser maior que o esquerdo, neste trabalho. Afirmaram também que faces simétricas e harmoniosas podem exibir uma assimetria esquelética, porém os tecidos moles minimizam esta assimetria.

Em 1981, CHEBIB; CHAMMA ${ }^{31}$, avaliaram a assimetria craniofacial de 64 adultos leucodermas de ambos os sexos por meio da radiografia póstero-anterior. Oito pontos ímpares localizados na linha mediana e 12 pontos pares laterais foram selecionados para o método matemático de mensuração da assimetria craniofacial pelo sistema de coordenadas $\mathrm{X}$ e $\mathrm{Y}$. Verificaram que a assimetria era menos freqüente na região mediana do que nas laterais e nenhuma diferença significante foi encontrada em relação ao sexo. As estruturas da região dentoalveolar mediana da maxila, a porção inferior do nariz e o mento mostraram grandes desvios estatísticos dentre todas as estruturas analisadas. Uma significante assimetria horizontal do lado esquerdo estava presente nas estruturas ósseas, com comprometimento muscular associado: temporal (músculo temporal), côndilo (pterigóideo lateral), maxila (bucinador), zigoma (músculos zigomáticos), osso mastóideo (esternocleidomastoideo) e região goníaca (masseter e pterigóideo medial). Desta forma, concluíram que existe uma diferença entre as estruturas craniofaciais dos lados esquerdo e direito, sendo que o lado esquerdo apresenta uma maior assimetria horizontal e menor assimetria vertical, apesar destes dados necessitaram de mais pesquisas para sua confirmação. 
Anos mais tarde, KANTOMAA ${ }^{80}$, em 1989, afirmou que o contorno da eminência articular mostra grande variação individual, podendo relacionar-se com a morfologia da face. A morfologia mandibular correlaciona-se com a inclinação da superfície articular da fossa glenóide, de modo que uma mandíbula retangular decorre de uma fossa profunda, enquanto que uma mandíbula triangular provém de uma fossa rasa. Desta forma, concluiu-se que a morfologia da fossa glenóide constitui-se num elemento essencial do crescimento mandibular, havendo um íntimo relacionamento entre sua posição e algumas discrepâncias esqueléticas e as más oclusões. A fossa glenóide, nas más oclusões de Classe I, localiza-se mais anteriormente do que na Classe II, enquanto que na Classe III, relaciona-se mais anteriormente em relação ao crânio.

PIRTTINIEMI; KANTOMAA; RONNING ${ }^{126}$, em 1990, compararam as dimensões da fossa glenóide e a morfologia craniofacial, utilizando telerradiografias laterais de 59 crânios, com dentição completa. Oito medidas angulares foram utilizadas para descrever a forma da base craniana, da mandíbula e da superfície articular da fossa glenóide e quatro medidas lineares descreveram a posição da fossa e somente uma descreveu o tamanho de todo o crânio. Verificaram uma relação próxima entre a morfologia da superfície articular da fossa glenóide e a morfologia mandibular. O ângulo da base do crânio associava-se com a posição da fossa glenóide de duas maneiras. Basicamente, a posição da fossa estava relacionada com as características da base do crânio, mas a localização da eminência articular em relação ao plano clivoso sugeriu que o côndilo mandibular pode causar uma remodelação da eminência anteriormente, quando a fossa glenóide, de modo contrário, transloca-se posteriormente em associação com a base do crânio.

Utilizando-se de radiografias póstero-anteriores, PECK; PECK; KATAJA ${ }^{122}$, em 1991, avaliaram a intensidade e a variabilidade morfológica da assimetria craniofacial subclínica. Estudaram uma amostra de 52 adultos leucodermas, apresentando bom equilíbrio facial, sendo 49 jovens do sexo feminino e três do sexo masculino, com idade média de 21 anos e dois meses. A determinação da 
assimetria esquelética foi realizada por meio de três medidas bilaterais esqueléticas que foram: órbita látero-superior, zygoma e gônio. A diferença entre os lados esquerdo e direito da hemiface foi quantificada em milímetros para que a largura total entre os pontos bilaterais fossem calculados. Os valores absolutos da diferença esquerda-direita foram utilizados para computar a média absoluta da assimetria entre cada uma das três dimensões estudadas. A órbita látero-superior demonstrou a menor assimetria e a menor variabilidade das três dimensões avaliadas, enquanto que a distância vertical entre o zygoma e o gônio revelou a mais forte diferença assimétrica na amostra. Já que estas duas últimas medidas relacionam-se com a oclusão dentária, concluíram que a posição dos dentes pode determinar um desenvolvimento significante da assimetria. Testes adicionais para determinar a dominância esquerda-direita dos dados também foram realizados. Os resultados revelaram que houve uma ligeira dominância para o lado direito, embora não tenha sido estatisticamente significante. Concluíram que o complexo craniofacial exibe uma menor assimetria e uma maior estabilidade dimensional à medida que se aproxima do crânio, validando o uso do ponto cefalométrico orbital látero-superior como ponto de referência craniano estável no cefalograma frontal.

Mais especificamente, a assimetria mandibular, em observações clínicas e radiográficas, resulta em um crescimento acelerado do côndilo mandibular de um lado ou o decréscimo do crescimento do lado oposto. TALLENTS et al. ${ }^{166}$, em 1991, comentaram que a assimetria mandibular geralmente relaciona-se com uma hiperplasia condilar unilateral associada a um crescimento acelerado. Comentaram que as conseqüências das assimetrias mandibulares poderiam ser a mordida aberta, o desvio da linha média mandibular em direção contrária ao maior lado, a inclinação do plano oclusal e a mordida cruzada do lado mais curto. As alterações faciais mais comuns são o desvio do mento, em sentido contrário ao lado mais longo ou proeminência ou achatamento da região goníaca. Concluíram que o ângulo goníaco geralmente se encontra mais agudo no lado mais comprido.

PIRTTINIEMI; KANTOMAA ${ }^{125}$, em 1992, estudaram a assimetria na forma e localização da articulação temporomandibular e sua relação com a assimetria 
mandibulofacial. Para tanto, analisaram 40 crânios adultos, de ambos os sexos, sem defeitos estruturais morfológicos, representando um grupo racial uniforme do século XIX, pertencente ao Departamento de Anatomia, da Universidade de Helsinki, na Finlândia. Utilizaram radiografias submentonianas, laterais e póstero-anteriores cuja configuração da fossa era claramente definida. Os resultados mostraram uma assimetria temporomandibular direcional generalizada. A fossa glenóide do lado direito estava mais posicionada lateral e posteriormente do que a esquerda, quando analisada na visão axial. A mandíbula estava geralmente mais comprida no lado esquerdo do que do lado direito, na visão frontal. A assimetria temporomandibular encontrada neste estudo relacionava-se com as características da base do crânio e as diferenças direita-esquerda do comprimento mandibular. A linha média dentária inferior estava mais desviada para a direita do que para a esquerda pela visão frontal, sugerindo uma tendência a uma oclusão normal, do lado direito e um comprimento mandibular maior para o lado esquerdo. Este aspecto relaciona-se com a assimetria condilar, uma vez que a superfície articular é mais íngreme no lado direito do que no esquerdo. Desta forma, a direção de crescimento condilar no lado direito favorece uma tendência pós-normal na oclusão. A razão básica para o relacionamento assimétrico direcional vinculourse com a interação recíproca entre o desenvolvimento assimétrico da base do crânio e a influência da função direcional.

A avaliação da morfologia craniofacial consiste numa indispensável ferramenta na prática clínica e em pesquisa, podendo ser obtida de diferentes maneiras, sendo as telerradiografias e as fotografias extrabucais freqüentemente utilizadas. Estes recursos promovem a mensuração dos pontos, oferecendo também uma avaliação analítica e completa do aspecto craniofacial do indivíduo que está sendo investigado. Em 1993, FERRARIO et al. ${ }^{43}$ utilizaram um protocolo padronizado para descrever quantitativamente a estrutura do tecido mole craniofacial, os relacionamentos entre as estruturas faciais e a postura da cabeça em relação ao solo. Para tanto, obtiveram fotografias frontais e laterais de 108 adultos jovens saudáveis ( 57 do sexo masculino e 51 do sexo feminino) registradas em duas posições: em pé e sentado. No sexo masculino, as faces mostraram-se, em média, mais largas e mais longas que as faces do sexo feminino, em ambas as 
fotografias, com as maiores diferenças nas regiões da boca e do mento. Ambos os sexos eram, de forma geral, simétricos. Os jovens que eram assimétricos, foram compensados pela alteração da postura da cabeça em relação ao solo, de tal forma que no plano frontal, o eixo interpupilar e o plano oclusal ficavam paralelos ao solo. A inclinação do plano de Frankfürt, em relação ao solo, dos pacientes avaliados neste estudo revelou algumas variações que dependeram da postura corporal e do gênero. Na posição de pé, o plano de Frankfürt posicionourse para cima e para frente, com um ângulo de $13^{\circ}$ em relação ao solo, enquanto que na posição sentada, apresentou-se mais horizontal (cinco graus no sexo masculino e oito graus, no feminino). Esse resultado confirma a necessidade de uma reavaliação cuidadosa dos protocolos padrões para a obtenção das radiografias e fotografias, quando os pacientes se posicionam em pé e sentado.

Pouco se sabe à respeito da prevalência das assimetrias ortodônticas. Em 1998, SHEATS et al. ${ }^{153}$ fizeram uma estimativa da magnitude de prevalência da assimetria dentária e facial em jovens americanos, sem história de tratamento ortodôntico prévio e compararam com os dados estatísticos de um grupo submetido ao tratamento ortodôntico. A amostra de pacientes sem tratamento foi selecionada numa escola pública da Flórida, sendo composta de dois grupos de jovens: 0 primeiro era constituído de 5.817 jovens, com média de idade entre $9,3 \pm 0,8$ anos e o segundo, de 861 adolescentes entre 14,4 \pm 0,5 anos. A assimetria sagital do molar era encontrada em $30 \%$ dos jovens do primeiro grupo e em $23 \%$ dos jovens do segundo grupo. Uma avaliação adicional da assimetria no segundo grupo mostrou $12 \%$ de assimetria facial e $21 \%$ de não coincidência das linhas médias dentárias. No grupo de pacientes em tratamento, verificaram que a assimetria mais comum era o desvio da linha média inferior em relação à linha média facial, ocorrendo em 62\% dos pacientes. Outras assimetrias ocorreram em ordem decrescente: falta de coincidência das linhas médias dentárias (46\%); desvio da linha média maxilar em relação à linha média facial (39\%); má oclusão assimétrica (22\%); assimetria oclusal maxilar (20\%); assimetria oclusal mandibular (18\%); assimetria facial (6\%); desvio do mento (4\%) e desvio nasal (3\%). Concluíram que não há associações significantes entre a assimetria facial e a não coincidência das 
linhas médias. Entretanto, associações estatisticamente significantes foram encontradas em relação à assimetria do molar e a assimetria facial, a assimetria do molar e a não coincidência das linhas médias e a assimetria do molar e o tipo racial. Os resultados desta pesquisa não puderam ser considerados precisos devido à deficiente metodologia para a avaliação da assimetria. Os autores comentaram que os examinadores não foram adequadamente calibrados e ainda, os pacientes avaliados não foram analisados quanto à presença de desvios da relação cêntrica para a oclusão cêntrica e nem mesmo, com relação à coincidência das linhas médias.

\section{2 - O desenvolvimento da assimetria craniomaxilofacial e a oclusão dentária}

Alguns pesquisadores ${ }^{17,33,121,175,182}$ mostraram que a assimetria craniofacial ocorre freqüentemente na maioria da população, sendo a assimetria uma condição que independe da má oclusão ${ }^{45,87,95}$.

Comentando sobre os vários tipos e combinações de desenvolvimento assimétrico, $\mathrm{CHENEY}^{32}$, em 1952, assegurou que há situações que podem envolver estruturas profundas das bases apicais ou dos arcos dentários, ou ainda, apresentar diferenças em tamanho e forma dos arcos dentários opostos. Afirmou também que cada problema apresenta uma natureza individual, não existindo regras fixas ou padrões de tratamento para a correção destas más oclusões. Em muitos pacientes, um lado da face difere do outro, devendo-se planejar o tratamento destes casos no sentido de resolver os problemas dentoesqueléticos, de acordo com a necessidade individual. Concluiu que nem todo tratamento ortodôntico deve ser realizado bilateralmente, ou seja, de maneira simétrica, pois há assimetrias intrínsecas das bases apicais, existindo também as assimetrias entre as bases apicais e as desarmonias entre as formas dos arcos dentários.

A assimetria facial, segundo $\mathrm{FISCHER}^{45}$, em 1954, não necessariamente interfere na obtenção da correta oclusão. Baseando-se nisto, pacientes com oclusão normal, apresentando as linhas médias superior e inferior coincidentes entre 
si apresentaram uma maior assimetria para o lado direito da face ${ }^{151}$. Entretanto, BRASH; MCKEAG ${ }^{19}$, em 1956, comentaram que a assimetria facial ocorre devido a uma assimetria de desenvolvimento do cérebro por razões funcionais ou devido a um hábito muscular assimétrico, como a mastigação unilateral.

Anos depois, CHENEY ${ }^{33}$, em 1961, pesquisando sobre as assimetrias e sua significância clínica, relatou que existem quatro tipos de assimetrias dentofaciais que seriam resultantes de diferenças ântero-posteriores unilaterais, diferenças de altura (desarmonia vertical); diferenças laterais horizontais (deslocamentos laterais) e rotações do complexo maxilar ou do ramo mandibular, associadas ou não à variações de tamanho unilaterais. Verificou que todas estas alterações assimétricas atuariam afetando o tamanho, a forma e a posição das duas hemifaces direita e esquerda. Desenvolveu um método de identificação e descrição das assimetrias faciais, estabelecendo pontos anatômicos de referência para comparação entre os lados direito e esquerdo. Para tanto, utilizou fotografias extrabucais frontais, de perfil e da região mandibular numa visão axial para a análise das assimetrias dos tecidos moles. Posteriormente, radiografias póstero-anteriores e modelos de estudo foram obtidos para se avaliar as assimetrias esqueléticas e dos arcos dentários, respectivamente.

Avaliando a inter-relação entre a oclusão dentária e a presença ou ausência de assimetria da base do crânio ou mandibular no plano frontal, LETZER; $\mathrm{KRONMAN}^{87}$, em 1967, compararam um grupo de 50 pacientes possuindo oclusão excelente com 50 pacientes apresentando más oclusões. O critério de determinação da oclusão excelente baseourse em um relacionamento ântero-posterior normal dos arcos dentários, uma sobremordida normal, uma tolerância de apinhamento de no máximo três milímetros dos arcos dentários e um espaço interproximal inexistente ou mínimo. A idade média da amostra variou de 9 a 11 anos e 11 meses, não considerando o sexo dos pacientes. Os traçados cefalométricos foram realizados, bem como a determinação dos pontos de referência nas radiografias pósteroanteriores. Uma análise angular simplificada envolvendo o mínimo número de dentes foi conduzida e os pontos orbitário bilateral, extensão lateral do gônio e as 
linhas médias da maxila e da mandíbula foram obtidas. Os resultados desta investigação revelaram que não houve uma relação estatisticamente significante entre a oclusão e a simetria ou a assimetria da face. Entretanto, um grau significante de simetria, tanto na base craniana anterior como na mandíbula foi encontrada no grupo com oclusão normal. De modo contrário, ambos os grupos demonstraram uma assimetria, sugerindo-se que a assimetria facial constitui-se numa característica normal nos pacientes, sendo independente do tipo da má oclusão.

Grande parte dos estudos de assimetria dentoalveolar utiliza modelos dos arcos dentários, e mais freqüentemente, apenas o arco superior. Mesmo em pacientes com oclusão normal, determinados estudos relataram um certo grau de assimetria do arco dentário ao se utilizar a rafe mediana como eixo de simetria. Analisando a assimetria dos arcos dentários em pacientes com oclusão normal e com má oclusão, HECHTER ${ }^{61}$, em 1975, encontrou uma maior assimetria no arco inferior em ambos os grupos. Entretanto, verificou um aumento da assimetria, em ambos os arcos, quando a má oclusão estava presente.

$\mathrm{COOK}^{34}$, em 1980, afirmou que a anatomia craniofacial normal pode demonstrar graus variados de assimetria, desde a assimetria subclínica, compatível com a oclusão normal, até as assimetrias acentuadas, resultantes de causas traumáticas, patológicas ou do desenvolvimento. Comentou que a deformação do crânio pode ocorrer no útero, durante o nascimento ou na infância. Além disso, uma forma de deformação craniofacial, a plagiocefalia, pode acontecer algumas semanas após o nascimento em bebês que eram simétricos ao nascer. Salientou que a associação entre a assimetria facial, a assimetria da base craniana, a plagiocefalia e a assimetria do esqueleto axial tem sido intensamente investigada. Sugeriu que a plagiocefalia pode ser revertida espontaneamente para uma situação mais simétrica, enquanto que a base do crânio pode sofrer uma deformação permanente que pode posteriormente se relacionar com uma assimetria facial clínica. Concluiu que provavelmente todos as estruturas craniofaciais demonstram algum grau de assimetria, sendo geralmente subclínica e compatível com a oclusão normal. 
Anos depois, PONYI; SZABÓ; NYILASI ${ }^{29}$, em 1991, objetivaram elucidar se havia diferenças entre os lados direito e esquerdo de 18 medidas mandibulares de crânios europeus, de ambos os sexos, pertencentes aos séculos $X$ e XII, que estavam soterrados no sudeste húngaro. Desenvolveram uma pesquisa em que encontraram uma diferença estatisticamente significante apenas para a menor dimensão sagital do pescoço mandibular, nos dois sexos. Concluíram que a assimetria dos lados esquerdo e direito foi encontrada entre as dimensões mandibulares medidas individualmente em $41,4 \%$ dos crânios masculinos e 40,4\% dos crânios femininos.

Uma amostra longitudinal de jovens com idades, variando entre 6, 9, 12, 14 e 16 anos, pertencente ao Centro de Crescimento de Burlington, Ontário, Canadá foi avaliada por MELNIK ${ }^{101}$, em 1992. Este autor objetivou analisar a assimetria mandibular e as medidas do ângulo goníaco de ambos os lados, de acordo com o sexo e a idade, por meio da comparação das diferenças obtidas entre os lados direito e esquerdo, nas radiografias oblíquas a 45․ Os resultados demonstraram que as assimetrias eram comuns em todas as idades. Um maior comprimento mandibular no lado direito, manifestando-se aos 12 anos no sexo feminino e somente aos 16 anos, no sexo masculino, idade em que cinco a $10 \%$ das jovens apresentavam assimetrias maiores do que $5 \mathrm{~mm}$. Embora o sexo masculino tenha demonstrado uma maior assimetria mandibular, apresentando maior comprimento em idades mais precoces, após os 14 anos não houve mais diferenças entre os sexos. De modo contrário, diferenças significantes não existiram entre os ângulos goníacos dos lados direito e esquerdo, em relação ao sexo e à idade da amostra estudada.

Utilizando radiografias póstero-anteriores e modelos de estudo, MARTINS de ARAÚJO; SCHIRMER; ALMEIDA ${ }^{97}$, em 1994, avaliaram as assimetrias esqueléticas e dentárias em 20 pacientes com oclusão normal, com idade média de 22,4 anos. Para descrever o complexo craniodentofacial, demarcaram-se nove triângulos bilaterais. Calcularam a área de cada triângulo e a freqüência das assimetrias ântero-posterior e transversa, nos modelos. Quando os lados direito e esquerdo das 
radiografias foram comparados, testes $t$ de Student não mostraram diferenças significantes nas áreas dos triângulos, embora estas áreas, não tenham se apresentado simétricas. Os pacientes dos sexos masculino e feminino mostraram resultados similares, quando as áreas radiográficas dos triângulos foram comparadas entre os sexos. As linhas médias dentárias superior e inferior, a rafe palatina dos modelos e o plano sagital mediano nas radiografias mostraram-se quase coincidentes. Além disso, a freqüência das assimetrias dos molares, nos modelos, não apresentou diferença estatisticamente significante entre os dois lados, embora tenha havido assimetrias dos molares, maiores do que $1 \mathrm{~mm}$, em $50 \%$ dos casos. Estes autores afirmaram também que a assimetria normal não se constitui numa situação muito comum, enquanto que a assimetria anormal ocorre freqüentemente.

Em 1995, O’BYRN et al. ${ }^{116}$ conduziram uma pesquisa objetivando determinar se a simetria mandibular em adultos com mordida cruzada posterior unilateral era diferente daquela de adultos com más oclusões de Classe I, não tratadas. Trinta adultos, acima de 18 anos, com mordida cruzada posterior unilateral foram comparados com 30 adultos com más oclusões de Classe I. Radiografias submentonianas foram obtidas para se avaliar as simetrias esquelética e dentária, enquanto as tomografias horizontais corrigidas serviram para avaliar a posição condilar dentro da fossa glenóide. Em relação ao sistema de coordenadas mandibulares, o primeiro molar inferior, do lado da mordida cruzada, apresentava-se mais lateral e distalmente, em comparação com 0 do lado oposto. Esqueleticamente, a mandíbula não demonstrou assimetria. A mandíbula apresentou-se rotacionada em relação ao assoalho craniano, de forma que o côndilo do lado da mordida cruzada estava posicionado posteriormente em relação ao lado oposto. Concluiu-se que havia uma posição posterior relativa da fossa glenóide, uma vez que não se observou nenhuma assimetria mandibular esquelética ou deslocamento condilar dentro da fossa, como evidenciado nas tomografias corrigidas no grupo com mordida cruzada, quando comparadas com as do grupo de Classe I. Os autores questionaram se seria correto corrigir mordidas cruzadas posteriores unilaterais em adultos apenas ortodonticamente, com a movimentação dentária, 
considerando-se que a remodelação óssea da fossa glenóide já possa ter ocorrido. Concluíram que as adaptações tanto na posição mandibular, relativas ao sistema de coordenadas do assoalho craniano, como na dentição, em relação ao sistema de coordenadas mandibulares, existem em adultos com mordida cruzada posterior não tratada. Com a correção do problema oclusal, há um aumento da possibilidade destas alterações ocorrerem dentro da fossa glenóide. As mudanças suaves da posição condilar relacionam-se com a capacidade adaptativa de alguns pacientes em tolerar o desconforto e a dor.

PIRTTINIEMI ${ }^{124}$, em 1998, relatou que a assimetria normal na região do esqueleto craniofacial pode ser direcional ou flutuante. A direcional pode ser encontrada em três dimensões: ântero-posterior; craniocaudal e assimetrias nas dimensões direita e esquerda. Quando ocorre por diferença bilateral, sua justificativa torna-se complexa, apesar de se manifestar freqüentemente. Em geral, concluiu que quando a assimetria funcional aumenta com a idade, há uma dificuldade em se determinar a contribuição exata de cada fator etiológico envolvido. Afirmou também que a influência da oclusão no desenvolvimento das estruturas faciais harmoniosas exerce suma importância durante os primeiros anos de vida.

Neste mesmo ano, LEGAN ${ }^{85}$ comentou que a mandíbula exerce uma contribuição dominante para a assimetria dentofacial já que forma o suporte esquelético dos tecidos moles da face inferior. De modo contrário, a maxila contribui com um suporte mínimo para os tecidos moles, apresentando pequena participação na assimetria. Afirmou também que a maioria das assimetrias maxilares é secundária ao crescimento mandibular assimétrico, podendo ser mensurada simplesmente pela localização da linha média dentária superior e pela inclinação do plano oclusal frontal.

Ainda em 1998, SHROFF; SIEGEL ${ }^{155}$ comentaram que a fratura condilar na infância associa-se a um crescimento limitado, contruibuindo, conseqüentemente, para o aparecimento da assimetria. À medida que o crescimento facial prossegue, a mandíbula progressivamente desvia-se para o lado afetado, ou, em alguns casos, 
pode ocorrer um crescimento compensatório excessivo no lado da fratura, hiperplasia condilar, produzindo uma assimetria com desvio mandibular para o lado oposto ao afetado. Quando a articulação temporomandibular sofre uma injúria, ocorre a formação de uma artrose intracapsular, apresentando grande potencial para produzir uma anquilose $\operatorname{articular~}^{132}$. Além da presença da assimetria, uma restrição na abertura bucal se manifesta devido à falta do movimento de translação condilar no lado afetado. Uma assimetria maxilar compensatória, uma inclinação do plano oclusal e uma disfunção temporomandibular podem estar associadas a estas assimetrias. As doenças degenerativas articulares unilaterais predispõem ao aparecimento da assimetria. A reabsorção condilar progressiva, quando ocorre bilateralmente, associa-se a uma mordida aberta anterior e a uma retrognatia mandibular progressiva. Nos casos de reabsorção condilar unilateral, a assimetria agrava-se paulatinamente e o lado afetado vai se tornando cada vez mais Classe II.

A maioria dos casos de mordida cruzada posterior ocorre quando a discrepância oclusal resulta da insuficiência da largura do arco superior em relação ao inferior. Em jovens, a mordida cruzada posterior unilateral usualmente acompanha o desvio funcional lateral mandibular do contato inicial até a máxima intercuspidação, resultando em uma intercuspidação deficiente e interferências oclusais. Este desvio funcional ocorre transversalmente, com a linha média dentária inferior desviada em direção ao lado cruzado em relação à linha média superior, bem como no sentido ântero-posterior, resultando geralmente numa má oclusão de Classe II, subdivisão no lado da mordida cruzada. LAM; SADOWSKY; OMERZA ${ }^{84}$, em 1999, verificaram a diferença entre a posição condilar em jovens com mordida cruzada funcional e jovens com má oclusão de Classe I, sem mordida cruzada. Além disso, avaliaram se havia uma alteração na posição condilar, após a correção da mordida cruzada pela expansão palatina. Trinta e um jovens entre 6 a 14 anos, com mordida cruzada posterior unilateral foram comparadas com uma amostra controle de 31 jovens entre 9 a 14 anos, exibindo Classe I de Angle, sem mordida cruzada. Radiografias submentonianas foram obtidas, antes do tratamento, para se estudar a assimetria esquelética, dentária e posicional com referência aos sistemas de coordenadas mandibulares e do assoalho craniano. Adicionalmente, os espaços 
condilares anterior, superior e posterior foram medidos para se determinar as diferenças entre os grupos com o uso de tomografias horizontais corrigidas da ATM, pré e pós-tratamento, além dos modelos de gesso. Finalmente, a distância entre a cúspide mesiovestibular do primeiro molar permanente à fossa vestibular do primeiro molar inferior foram medidas em ambos os grupos, antes do tratamento. Pela análise estatística, verificou-se que a mandíbula do grupo com mordida cruzada posterior funcional unilateral exibia uma assimetria nas dimensões ântero-posterior e transversa quando comparadas com o grupo de Classe I, sem mordida cruzada. Estas assimetrias provavelmente resultaram de um desvio funcional mandibular presente em todos os pacientes do grupo com mordida cruzada. Este desvio foi manifestado pela Classe II, subdivisão no lado da mordida cruzada como indicado na análise dos modelos. Os resultados das tomografias horizontais corrigidas não evidenciaram qualquer diferença na relação côndilo-fossa intra e intergrupos, pré e pós-tratamento.

\section{3 - Fatores etiológicos determinantes da assimetria dentofacial}

As causas das assimetrias dentofaciais geralmente incluem más formações genéticas ou congênitas, como a microssomia hemifacial; fatores ambientais, como o trauma; desvios funcionais; desvios mandibulares resultantes de interferências dentárias; fatores epigenéticos e adquiridos, como infecções ou patologias ${ }^{85}$. desenvolvimento da assimetria facial com desvio da linha média e do mento para um lado ocorre quando o crescimento mandibular de um lado aumenta ou diminui, comparando-se com o do lado oposto. Várias causas podem estar relacionadas, podendo a assimetria ser congênita ou adquirida.

Um dos objetivos do controle do desenvolvimento oclusal e da correção da má oclusão consiste no estabelecimento de uma simetria da forma dos arcos individualmente e do relacionamento oclusal maxilomandibular. A simetria da forma dos arcos relaciona-se com as inclinações axiais e rotações dos dentes individualmente. A oclusão não somente é afetada pela posição dos dentes, mas também pelo padrão de crescimento esquelético. As assimetrias mandibulares 
podem estar relacionadas não somente com uma posição assimétrica, como também em relação à morfologia assimétrica mandibular. Diferenças no comprimento do corpo mandibular, bem como, na altura do ramo podem estar relacionadas com as assimetrias. O desenvolvimento de uma assimetria pode se iniciar na vida fetal, podendo também ser resultante de distúrbios do desenvolvimento pós-natal, como o trauma do côndilo mandibular ${ }^{82}$.

WILLIAMSON $^{178}$, em 1981, comentou que a assimetria ocorre freqüentemente devido a fatores genéticos, funcionais e traumáticos. Quando uma assimetria existe, ocorre uma maior severidade da má oclusão de Classe II apenas de um lado, ocasionando uma Classe II, subdivisão. Afirmou também que quando o ortodontista trata em relação cêntrica, o plano de tratamento dos casos deve utilizar ancoragem máxima no arco superior, do lado deficiente. Em alguns casos severos, pode se chegar a uma relação de topo a topo, no lado mais curto da mandíbula, ao final do tratamento, considerando-se um sucesso. Quando se manipula a mandíbula em relação cêntrica, os dentes inferiores posicionam-se mais distalmente, comparandose com os superiores, causando uma discrepância de linha média, com desvio mandibular para o lado deficiente, quando o côndilo se assenta. Como exemplo clínico, este autor citou um caso em que os elásticos assimétricos foram utilizados, não corrigindo a linha média. Relatou que, de um modo geral, 32\% dos pacientes apresentam $3 \mathrm{~mm}$ ou mais de assimetrias mandibulares que podem ser verificadas em radiografias póstero-anterior e submentoniana ${ }^{179}$. Três milímetros equipara-se aproximadamente à largura de uma cúspide, levando uma Classe I, em máxima intercuspidação, para uma Classe II, em relação cêntrica. As assimetrias aparentemente podem ocorrer por deficiência do corpo mandibular de um lado, visualizadas pela radiografia submentoniana, ou pela deficiência de crescimento vertical, quando evidenciadas pela radiografia póstero-anterior. Em ambos os casos, o relacionamento de molar e de canino é mais Classe II, no lado deficiente, quando verificado em modelos de gesso articulados. Uma discrepância de linha média pode ser uma indicação de uma assimetria, sugerindo que um lado da oclusão pode ser mais Classe II que o outro. Se uma assimetria está presente e o caso está sendo tratado com o conceito de posição assentada no côndilo, o profissional deve 
terminar o caso com um lado mais Classe II que o outro. WILLIAMSON ${ }^{178}$ comentou que as forças dos elásticos intermaxilares podem empurrar o côndilo para frente e para fora da posição de repouso, no lado da Classe II, havendo a correção da discrepância de linha média, mas um côndilo não fica totalmente assentado. Se nenhum crescimento compensatório ocorre, a discrepância de linha média pode ser corrigida, porém um côndilo não fica assentado, havendo a produção de uma deflexão da oclusão de relação cêntrica até a máxima intercuspidação. Concluiu que nos problemas de linha média devido às discrepâncias de tamanho dentário, o plano de tratamento pode envolver extrações assimétricas, quando o caso permitir, ou aceitação do problema, em casos sem extração, com indicação de ajuste oclusal, ao final do tratamento.

Anos depois, PIRTTINIEMI et al. ${ }^{127}$, em 1991, objetivaram mensurar a assimetria sagital na posição bicondilar em relação à parede posterior da fossa glenóide e à base do crânio, sagital e transversalmente, por meio de tomografias axiais computadorizadas. Determinaram, também, a existência de uma correlação com certas assimetrias oclusais e associações entre as assimetrias oclusal e temporomandibular em adultos jovens com más formações, em tomografias computadorizadas. A amostra consistiu de 49 adultos dos 15 aos 33 anos, apresentando todos os dentes nos arcos. O côndilo esquerdo localizou-se mais anteriormente e mais próximo da linha média da base do crânio do que o direito. Encontraram um espaço articular entre o côndilo e a parede posterior da fossa glenóide maior do lado esquerdo. Correlacionourse a assimetria da posição bicondilar com a assimetria oclusal, desta forma, pacientes com más oclusões mostraram uma posição mais assimétrica dos côndilos em relação à parede posterior da fossa glenóide. Observourse a grande importância clínica deste resultado e se questionou a necessidade da correção precoce destas más oclusões, uma vez que uma completa adaptação não parece ocorrer nestes casos. Concluíram que a assimetria condilar foi encontrada em adultos jovens, sendo esta assimetria no plano sagital significantemente relacionada aos desvios de linha média dentária e relações oclusais. Nos casos de má oclusão subdivisão, a distância côndilo-fossa sofreu um aumento unilateral. 
SCHELLHAS; POLLEI; WILKES ${ }^{144}$, em 1993, relataram a relação entre a assimetria da linha média facial adquirida e o deslocamento de disco em jovens, enquanto WESTESSON ${ }^{174}$, em 1994, descreveu esta mesma questão, em adultos. Entretanto, em ambos os trabalhos, não foi relatado se a assimetria predispõe ao desenvolvimento de deslocamento de disco da articulação temporomandibular, ou se este deslocamento pode causar desvio mandibular, durante o crescimento.

Utilizando a radiografia póstero-anterior como método de identificação da assimetria mandibular, SKOLNICK et al. ${ }^{160}$, em 1994, avaliaram 56 casos cirúrgicos e 109 casos ortodônticos buscando a inter-relação entre o trauma pré-pubescente e o desenvolvimento da assimetria mandibular. Verificaram uma associação estatisticamente significante entre a história de trauma pré-pubescente e a assimetria mandibular, por meio das radiografias frontais tanto nos casos cirúrgicos como no grupo de pacientes ortodônticos. Nos casos cirúrgicos, a história de trauma facial pré-pubescente foi constatada em seis pacientes, sendo que todos apresentavam assimetria mandibular, enquanto que no grupo dos pacientes ortodônticos, 20 jovens apresentavam história de trauma e 11 apresentavam assimetria mandibular. Finalmente, concluíram que existe uma associação estatisticamente significante entre a evidência radiográfica de assimetria mandibular e a história de trauma facial pré-pubescente.

A microssomia hemifacial consiste numa síndrome muito freqüente que causa a assimetria da face, progredindo com o desenvolvimento pós-natal, caso não seja tratada. A condição caracteriza-se pela assimetria mandibular em diferentes graus de severidade, sendo a oclusão geralmente afetada. A distorção secundária do crescimento pode ser vista pelo crescimento mandibular vertical inadequado como conseqüência da falha do crescimento do terço médio da face ${ }^{104}$.

VARGERVIK $^{171}$, em 1998, conceituou a microssomia hemifacial como um defeito congênito unilateral pós-natal que atinge estruturas esqueléticas, neuromusculares e outros componentes do tecido mole do primeiro e segundo arcos branquiais. O termo microssomia hemifacial envolve um amplo espectro de 
anomalias, podendo incluir problemas oftálmicos, renais, da coluna vertebral e envolvimentos cardíacos. Considerou que a microssomia hemifacial seria a segunda anomalia cardíaca mais comum depois das fendas labiopalatais, apresentando uma maior predominância no sexo masculino e no lado direito. Os casos mais severos podem apresentar má formação auricular, envolvendo o osso temporal e a fossa glenóide, estruturas articulares ausentes, incluindo o ramo mandibular, os processos coronóide e condilar.

Em jovens pré-pubescentes, a maior causa da assimetria severa consiste na anquilose da ATM e limitação do seu movimento, resultante da fratura condilar unilateral. Quanto maior o grau de inibição da mobilidade associada ao crescimento ativo, mais rápida e severa será a assimetria. A anquilose óssea da ATM pode produzir uma assimetria tridimensional facial, envolvendo ambos os maxilares, sendo um grande desafio cirúrgico. Uma vez que a anquilose é liberada cirurgicamente, um material interposicional biocompatível deve ser colocado. Em adição, os desarranjos internos unilaterais da ATM com ou sem história prévia de fratura condilar mandibular pode ser a causa principal da assimetria facial. A microssomia hemifacial consiste numa causa comum da assimetria facial em jovens, apresentando uma deformação típica da orelha e do ramo mandibular, com côndilo e tecidos moles associados inadequados ou ausentes. A severidade desta condição pode ser variada e o tratamento deve ser iniciado precocemente para auxiliar na prevenção de uma maior expressão da assimetria. A distração osteogênica consiste numa excelente modalidade de tratamento do paciente em crescimento na tentativa de estimular o desenvolvimento dos tecidos mole e duro. Nos casos mais severos, há necessidade de uma reconstrução da ATM com enxerto costocondral, além das cirurgias ortognática e dos tecidos moles ${ }^{85}$.

A rotação e a inclinação axial anormal dos primeiros molares superiores permanentes, devido à perda prematura dos molares decíduos, constituem-se fatores determinantes da assimetria dentária. A mesialização com inclinação para anterior dos molares permanentes, resulta em perda significante de espaço na porção posterior do arco dentário. Outro fator desta rotação seria a erupção 
ectópica mesial do molar. Durante o desenvolvimento, as coroas dos molares superiores estão voltadas para distal e durante o crescimento, quando a maxila se desloca para frente e para baixo, os molares superiores se verticalizam, ficando suas coroas voltadas para oclusal. Comentaram que uma rotação mesial do molar superior resulta numa relação de molar de Classe II mais acentuada no lado afetado. Pela visão oclusal, os arcos podem ser avaliados quanto à simetria, pela rafe mediana e sua projeção no arco mandibular por meio de uma estrutura plástica transparente sobreposta à superfície oclusal dos dentes. A maneira mais eficiente de se avaliar a rotação dos molares consiste em desenhar uma linha ao longo da superfície mesial do molar em cada lado do arco e observar o ponto de intersecção destas duas linhas ${ }^{155}$.

Recentemente, LEGRELL; ISBERG ${ }^{86}$, em 1999, propuseram-se a pesquisar se o deslocamento de disco da ATM causa desvio mandibular e o desenvolvimento da assimetria da linha média mandibular em coelhos durante o período de crescimento. Estudos experimentais em coelhos ${ }^{59,166}$ devem ser considerados relevantes porque o mesmo padrão de desvio mandibular durante o crescimento após a restrição de movimento mandibular tem sido registrado em seres humanos ${ }^{69}$ e em macacos ${ }^{70}$, indicando que não há diferença entre estas espécies a respeito do impacto da função mandibular alterada no padrão de crescimento mandibular. Desta forma, concluíram que o deslocamento de disco, não tratado, em coelhos em período de crescimento provoca a assimetria do comprimento mandibular com desvio da linha média para o lado ipsilateral.

Ainda em 1999, SJURSEN; LEGAN; WERTHER ${ }^{159}$ publicaram um caso clínico de uma jovem de 28 anos com assimetria facial conseqüente a um trauma na infância, mencionando que este fator poderia ter implicado no desenvolvimento desta assimetria. Pela análise dentária, a paciente apresentava uma Classe II, com sete milímetros de sobressaliência, mordida aberta anterior, desvio da linha média dentária inferior para o lado esquerdo e deslocamento mandibular para a direita, durante o movimento de abertura de boca. Diagnosticou-se também um excesso vertical da maxila acompanhado de uma deficiência do arco superior, no sentido 
transverso e uma assimetria mandibular do lado esquerdo, além da presença de um desnivelamento da órbita esquerda, constatado pela análise facial. Como plano do tratamento, optou-se pela combinação da terapêutica cirúrgica-ortodôntica, corrigindo as discrepâncias de linha média, a má oclusão, as assimetrias mandibular e vertical e a inclinação do plano oclusal, obtendo-se uma oclusão funcional e estética facial satisfatórias, ao final do tratamento. Concluíram que o trauma prépubescente geralmente está vinculado como uma das causas do crescimento mandibular assimétrico.

\section{4 - A Classe II, subdivisão e sua relação com a assimetria}

Numa observação cuidadosa, pode-se verificar alguns graus de assimetria em todas as faces. Embora algumas destas assimetrias sejam principalmente encontradas nos tecidos moles, contribuições esqueléticas podem estar presentes. O relacionamento oclusal assimétrico pode ser resultante de arcos intrinsicamente assimétricos ou de um relacionamento esquelético assimétrico maxilomandibular ${ }^{82}$. Deve-se determinar se a origem dos fatores, que causam a assimetria, consiste num problema dentoalveolar ou esquelético ou combinação de ambos ${ }^{134}$.

A relação de má oclusão de Classe II decorre de uma protrusão maxilar ou uma retrusão mandibular ou combinação de ambas estas características. Entretanto, algumas vezes, o complexo maxilomandibular pode estar bem relacionado e a Classe II resulta de uma má posição dos dentes em suas bases esqueléticas, estando os dentes superiores vestibularizados e os inferiores lingualizados em suas respectivas bases ósseas, ou uma combinação de ambos os $\operatorname{arcos}^{100,113,173}$. Enquanto que a Classe II, subdivisão pode ser conseqüente, primeiramente, da posição mais distal do molar inferior do lado da Classe $11^{1,73,137}$, ou secundariamente, da posição mais mesial do molar superior deste mesmo lado ${ }^{73}$.

No início do século XX, $\mathrm{ANGLE}^{4}$, em 1907, classificou as más oclusões de Classe II unilaterais em casos de subdivisão. Acreditava que a relação molar de Classe II se desenvolvia como resultado da erupção distal do primeiro molar inferior em relação à posição normal do primeiro molar superior. Além disso, assegurou, 
mais especificamente, que a Classe II unilateral, ou subdivisão decorria da erupção distal do primeiro molar inferior em relação ao primeiro molar superior do lado da Classe II.

Com o propósito de investigar se existe uma diferença lateral sistemática entre os lados direito e esquerdo do arco superior, HUNTER ${ }^{68}$, em 1953, afirmou que a simetria maxilomandibular seria normal e sugeriu que a assimetria lateral associa-se à má formação de um dos arcos dentários. A amostra foi selecionada aleatoriamente seguindo alguns critérios: os arcos não deveriam apresentar mutilações, hipoplasia do esmalte, restaurações e erupção insuficiente. Para tanto, traçou 93 modelos de jovens do sexo masculino com 13 anos de idade, utilizando projeções ortogonais paralelas ao plano oclusal dos arcos dentários. Para cada traçado, quatro medidas foram obtidas - as distâncias em milímetros da rafe mediana até o ponto da cúspide mesiolingual de cada primeiro molar e da rafe até a cúspide lingual dos primeiros pré-molares. Concluiu que nenhuma diferença sistemática pode ser demonstrada em ambos os lados.

Anos depois, baseando-se em três casos de má oclusão de Classe II, subdivisão com etiologia e tratamento distintos, WERTZ ${ }^{173}$, em 1975, relatou a dificuldade em se diagnosticar e tratar pacientes com Classe II unilateral devido à sua origem multifatorial. Salientou a importância em verificar se a origem da assimetria é dentária ou esquelética. Além disso, comentou que tanto para a Classe II como para a Classe III, subdivisão, a sínfise encontra-se desviada para o menor lado da mandíbula em relação à linha média facial, havendo também desvio mandibular. Nos casos de discrepância severa do crescimento mandibular, necessitava-se de uma correção cirúrgica que dependia da quantidade de distorção facial presente. Nas assimetrias dentárias, os segmentos dos arcos dentários destes pacientes devem ser identificados individualmente para o estabelecimento do correto plano de tratamento. Nestes casos, utiliza-se um dispositivo como um dos métodos de determinação da assimetria dentária em modelos de estudo. Para a sua aferição, tem-se como parâmetro a rafe palatina mediana como eixo de simetria, transferindo-se para o modelo inferior, em oclusão. Nos modelos superior e inferior, 
traçam-se duas perpendiculares a esta linha palatina mediana, ou seja, uma passando pela distal do molar localizado mais posteriormente no arco dentário e a outra, pelos pré-molares. Desta forma, a posição ântero-posterior dos dentes em cada um dos quatro quadrantes, pode ser avaliada, assim como o segmento responsável pela relação ântero-posterior incorreta ${ }^{1}$. Enfatizou a raridade em se encontrar qualquer magnitude de desarmonia esquelética, nestes casos, concluindo que devem ser diagnosticados e tratados, baseando-se no problema individual específico e evitando o emprego do mesmo método de tratamento para todos os casos.

Utilizando radiografias submentonianas e póstero-anteriores, WILLIAMSON; SIMMONS ${ }^{179}$, em 1979, estudaram a assimetria mandibular relacionada à dor e à disfunção. Foram radiografados 53 pacientes com má oclusão pré-tratamento ortodôntico, sendo 27 do sexo feminino e 26 do sexo masculino, com idade média de 14,2 anos, com a mandíbula posicionada em relação cêntrica. As diferenças entre os lados direito e esquerdo da mandíbula foram mensuradas nas duas normas radiográficas. O relacionamento dentário foi observado nos modelos para ver se existia uma má oclusão de Classe II mais acentuada no lado mais curto da mandíbula. A quantidade de dor pré-tratamento durante a palpação muscular foi correlacionada com o grau de assimetria encontrada. Nenhuma correlação estatisticamente significante foi demonstrada entre a assimetria mandibular e a sensibilidade muscular. Os resultados demonstraram que a má oclusão de Classe II de molar e de canino pode ser mais difícil de ser corrigida de um lado do que do outro, caso não haja uma compensação da posição da fossa glenóide ou dos dentes superiores. Verificaram que a maioria dos casos da amostra apresentavam assimetria, devendo os clínicos estarem cientes da sua presença em todos os três planos de espaço quando se planeja previamente o tratamento.

Em 1981, WILLIAMSON ${ }^{177}$ definiu a assimetria mandibular como sendo a diferença entre o tamanho e a forma dos dois lados da mandíbula, podendo ocorrer no plano frontal, no horizontal (basilar), ou em ambos, e ser refletida no plano sagital. Como a posição do côndilo em relação cêntrica influencia a avaliação da 
desarmonia esquelética, deve-se sempre diagnosticar e finalizar os casos nesta posição. Para se evidenciar alguma assimetria mandibular, deve-se recorrer às radiografias frontais e submentonianas, sempre realizando-as em relação cêntrica. Considerou que a assimetria sempre vem acompanhada de uma má oclusão como a Classe II, subdivisão ou uma Classe II bilateral, apresentando menor desenvolvimento mandibular do lado mais severo. Concluiu que ao se adotar o conceito de relação cêntrica para estes casos, o arco superior deve ser sempre planejado com ancoragem máxima, no lado deficiente.

Objetivando investigar a presença de diferenças significantes em relação às assimetrias faciais e dos arcos dentários, ALAVI; BEGOLE; SCHNEIDER ${ }^{1}$, em 1988, desenvolveram um estudo entre pacientes apresentando más oclusões de Classe II, subdivisão e com oclusão normal. Cada grupo constava de 28 jovens, com idade média de 17,1 anos, apresentando a dentição permanente até os primeiros molares. As medidas lineares foram obtidas nas telerradiografias, nas radiografias pósteroanteriores e nos modelos de estudo, enquanto as medidas específicas foram agrupadas para produzir vários índices de assimetria. Como método estatístico, utilizaram uma análise discriminante multivariada e verificaram que a assimetria ântero-posterior das más oclusões de Classe II, subdivisão devia-se principalmente à posição mais distal do molar inferior, do lado da Classe II. De modo contrário, não foi possível determinar se a posição do molar inferior era devido a uma assimetria esquelética ou dentoalveolar. Além disso, verificaram uma contribuição secundária da assimetria na região dentoalveolar da maxila.

Utilizando-se radiografias submentonianas, ROSE et al. ${ }^{137}$, em 1994, compararam a simetria mandibular de 58 pacientes. Um grupo experimental de 28 pacientes com más oclusões de Classe II, subdivisão, apresentando idade média de 28,4 anos, foi comparado com um grupo controle de 30 pacientes com más oclusões de Classe I, com idade média de 24,9 anos. Quarenta e quatro pacientes eram do sexo feminino e 14 do sexo masculino. A simetria foi avaliada medindo-se a diferença espacial relativa de pontos mandibulares nas dimensões ântero-posterior e transversa, determinadas pelos sistemas de coordenadas que representavam a 
mandíbula, o assoalho craniano e os dentes inferiores. Este trabalho limitou-se somente ao estudo da mandíbula, uma vez que as radiografias submentonianas não são específicas para a análise dos pontos maxilares. Somente aquelas variáveis que representavam a diferença ântero-posterior entre as posições dos molares inferiores direito e esquerdo demonstraram diferença estatisticamente significante entre os grupos. O primeiro molar inferior, quando avaliado em relação à base craniana ou à própria mandíbula, estava localizado mais posteriormente no lado da Classe II, nas más oclusões com subdivisão, em uma mandíbula que não exibia nenhuma assimetria. Qualquer diferença encontrada na assimetria mandibular não excluiu a possibilidade da presença de assimetria dentoalveolar ou esquelética no arco superior contribuir para as más oclusões com subdivisão. Concluíram que a mandíbula na Classe II, subdivisão não exibe uma posição esquelética anormal nem mesmo assimetria esquelética, sendo esta má oclusão decorrente das assimetrias dentárias.

Em 1994, MARTINS de ARAÚJO; SCHIRMER; ALMEIDA ${ }^{98}$ avaliaram as assimetrias esqueléticas e dentárias em 30 pacientes com idade média de 11,6 anos, apresentando Classe II, divisão 1, subdivisão. Utilizaram radiografias pósteroanteriores para verificar a presença de assimetria entre os lados de Classe I e de Classe II, divisão 1, subdivisão, além de modelos de estudo para se determinar a freqüência destas assimetrias. Nove triângulos bilaterais foram demarcados nos traçados cefalométricos para descrever o complexo craniodentofacial. Calculou-se a área de cada triângulo, nas radiografias e a freqüência das assimetrias ânteroposterior e transversa, nos modelos. Os resultados não demonstraram diferenças estatisticamente significantes entre os lados de Classe I e II, nas radiografias, entretanto, a freqüência de assimetrias nos modelos foi estatisticamente significante em nível de 1\%, sendo que o arco inferior apresentou maior assimetria que 0 superior. Estas assimetrias foram mais evidentes no plano ântero-posterior do que no transverso e, nos arcos inferiores, do que nos superiores. Concluíram que as más oclusões de Classe II, divisão 1, subdivisão são caracterizadas por desvios dentários e não por displasias esqueléticas, no plano frontal. 
SEVERT; PROFFI ${ }^{148}$, em 1997, avaliaram a prevalência de assimetria facial em uma população com deformidades dentofaciais na Universidade da Carolina do Norte. Avaliando 1.460 pacientes, detectaram que a assimetria facial clinicamente aparente estava presente em 495 pacientes, totalizando 34\% da amostra. Quando presente, a assimetria facial afetava a porção superior da face em apenas 23 casos (5\%), o terço médio, primeiramente o nariz, em 178 casos (36\%) e o mento em 365 casos (74\%). O plano oclusal apresentava-se inclinado, indicando uma assimetria vertical, em 201 casos (41\%). Os pacientes com Classe II, devido ou não à deficiência mandibular, apresentaram $28 \%$ de prevalência de assimetria, enquanto os de más oclusões de Classe III e Classe I apresentaram $40 \%$ de prevalência, tornando-se significantemente mais elevado do que aqueles com más oclusões de Classe II. Quando o mento se apresentava desviado transversalmente, houve $80 \%$ de chance que este desvio fosse para o lado esquerdo. Somente nos pacientes com face longa, houve um deslocamento igual do mento tanto para a esquerda como para a direita. Nos outros grupos, a prevalência do desvio do mento para o lado esquerdo alcançou 90\%. Concluíram que estes resultados são significantes para os clínicos porque a assimetria pode ser identificada e planejada antes do início do tratamento.

Ainda neste mesmo ano, LIN et al. ${ }^{90}$, investigaram por meio de cefalogramas póstero-anteriores, as diferenças das estruturas craniofaciais do adulto com relação ao sexo e à má oclusão e determinaram a distribuição da assimetria presente. Foram inseridas os dados de cada uma das sete medidas de 117 pacientes do sexo masculino e 38 do sexo feminino, em um disquete portátil compatível com um microcomputador. O sistema de análise de dados foi utilizado para o cálculo dos valores estatísticos univariáveis e para a produção de gráficos bivariáveis. Os resultados do estudo demonstraram que os parâmetros póstero-anteriores exibiram diferenças estatísticas entre os sexos, especialmente no plano sagital e a dimensão do crânio masculino foi maior do que a do crânio feminino. O padrão facial sofreu um desvio para a esquerda e a assimetria diferiu de acordo com a má oclusão. 
Muitos ortodontistas avaliam clinicamente a assimetria dentária pela comparação de pontos específicos nas superfícies oclusais dos modelos de gesso. Em 1998, MAURICE; KULA ${ }^{99}$ quantificaram e descreveram as assimetrias intraarcos maxilomandibulares de 52 jovens leucodermas na dentadura mista, determinando se havia um relacionamento entre as assimetrias intra e interarcos. 0 plano palatino mediano foi utilizado como referência para as medidas transversais e um mesmo plano foi construído no computador para as medidas ântero-posteriores. As assimetrias transversais excederam as assimetrias ântero-posteriores em magnitude e prevalência. A alta associação entre as posições ântero-posteriores e transversais interarcos indicaram que os arcos apresentavam dimensões similares. Concluíram que muitos jovens na dentadura mista apresentam assimetrias intraarcos mais severas e constantes no plano transversal do que no ântero-posterior e sugeriram que quando se encontra uma assimetria em um arco geralmente também ocorre em seu antagonista.

Pouco se conhece a respeito da assimetria dos arcos dentários na dentadura mista. KULA; ESMAILNEJAD; $\mathrm{HASS}^{83}$, em 1998, propuseram-se a quantificar e descrever as assimetrias dos arcos dentários de 151 jovens, com faixa etária entre 7 a 11 anos, com sobressaliência acentuada, objetivando determinar se havia uma relação espacial entre os pontos dentários nos arcos entre si. O plano palatino mediano foi a referência para as medidas transversais, enquanto que um plano palatino mediano construído transversalmente no computador foi a referência para as medidas ântero-posteriores. Mais do que 30\% dos jovens apresentaram assimetrias transversais maiores que $2 \mathrm{~mm}$ nos primeiros molares superiores permanentes. As mais altas médias de assimetrias transversal e ântero-posterior ocorreram nos primeiros molares superiores permanentes. Uma grande quantidade de jovens com sobressaliência acentuada apresentava assimetrias intra-arco significantes em muitos pontos bilaterais. Somente $3 \%$ destes jovens exibiam assimetrias intra-arco dos molares. A posição dos pontos em cada arco variou em relação às medidas nos arcos opostos. Apesar do grande número de pacientes com sobressaliência acentuada, muitos exibiram assimetrias intra-arcos significantes e poucos apresentaram assimetrias interarcos. 
Ainda em 1998, JANSON ${ }^{73}$ avaliou tridimensionalmente as assimetrias dentoesqueléticas das más oclusões de Classe II, subdivisão por meio de radiografias submentonianas, póstero-anteriores e oblíquas corrigidas. Objetivou investigar a presença de assimetrias dentárias e/ou esqueléticas entre 30 pacientes com oclusão normal e 30 jovens com más oclusões de Classe II, subdivisão. A amostra constava de pacientes de ambos os sexos, com idade média de 15,76 anos, para o grupo de Classe II, subdivisão e 22,42 anos, para o grupo de oclusão normal, sendo que todos apresentavam os dentes permanentes até os primeiros molares. Na radiografia submentoniana, avaliou-se a assimetria, medindo-se a diferença relativa na posição espacial de pontos dentários e esqueléticos nas dimensões ântero-posterior e transversa, determinadas pelo sistema de coordenadas, representando a mandíbula, o assoalho craniano, o complexo zigomaticomaxilar e os dentes inferiores e superiores. As variáveis foram analisadas pelo teste te pela análise de regressão logística de multivariáveis. Os resultados demonstraram que a principal diferença entre a má oclusão de Classe II, subdivisão e a oclusão normal consistia numa posição mais distal do primeiro molar inferior do lado da Classe II, em uma mandíbula com assimetria subclínica e sem assimetria de posição. Uma diferença secundária entre os dois grupos consistiu na posição mais mesial do primeiro molar superior, no lado da Classe II. De acordo com estes resultados, a linha média dentária inferior também apresentou um desvio mais freqüente para o lado da Classe II, do que a linha média dentária superior, no sentido oposto, conforme evidenciado na avaliação bidimensional da radiografia frontal. Cefalometricamente, os arcos dentários nos casos de má oclusão de Classe II, subdivisão, apresentaram uma maior assimetria do que os de oclusão normal.

\section{5 - Métodos de diagnóstico das más oclusões de Classe II, subdivisão}

Muitos métodos têm sido utilizados para se identificar e quantificar a magnitude das assimetrias, incluindo avaliações nas proporções verticais e horizontais da face pelo uso de fotografias faciais, análises radiográficas ou observações clínicas diretas. 
BURSTONE $^{25}$, em 1998, comentou que o diagnóstico das assimetrias dentárias e esqueléticas pode ser realizado pela avaliação esquelética do paciente e pelo padrão do tecido mole facial. As radiografias submentoniana e póstero-anterior são, particularmente, aplicáveis para o diagnóstico das assimetrias. A radiografia submentoniana auxilia mais precisamente no diagnóstico da assimetria, principalmente quando o problema é mandibular. As radiografias especializadas, como as tomografias computadorizadas e a utilização da estereometria com ou sem implantes, oferecem mais informações, porém consistem em recursos excessivamente sofisticados para o diagnóstico. Além disso, o tecido mole da face, a observação clínica precisa do aspecto frontal e inferior, juntamente com as fotografias faciais contribuem no diagnóstico para a detecção da existência de um problema esquelético.

Ainda neste ano, LEGAN ${ }^{85}$ afirmou que o diagnóstico das assimetrias dentofaciais, a história médica e os exames clínico, radiográfico e de modelos de estudo tornam-se necessários para se determinar a extensão do envolvimento do tecido mole, dos componentes esquelético e dentário, além do aspecto funcional. Comentou também que o exame clínico deve incluir uma análise intrabucal com a avaliação dos dentes e das linhas médias faciais, além da detecção de disfunção temporomandibular. Devendo-se identificar também a presença de alteração do plano oclusal como resultado do aumento ou diminuição unilateral do comprimento do côndilo ou ramo mandibular. O exame facial, pelas vistas frontal e lateral, deve ser conduzido para avaliar as assimetrias na morfologia facial e analisar a posição natural da cabeça. A palpação da maxila e do osso temporal, que suportam a fossa glenóide, podem estar em diferentes níveis em cada lado da cabeça. A avaliação do plano oclusal pode ser diretamente visualizada ao solicitar que o paciente morda uma espátula abaixadora de língua, posicionada horizontalmente, para se determinar seu relacionamento com o plano interpupilar. Ainda quanto ao aspecto frontal, considerou que a vista inferior da mandíbula ou a análise da radiografia submentoniana, auxilia na determinação da extensão da assimetria mandibular em relação ao resto da face. Concluiu que as assimetrias esqueléticas verticais 
associadas às mordidas abertas unilaterais progressivas podem ser resultantes da hiperplasia condilar ou neoplasia.

Convém salientar a importância em se diagnosticar os casos de má oclusão de Classe II, subdivisão em relação cêntrica para se verificar a real discrepância ânteroposterior que o paciente apresenta $25,73,134,155$. Se existir um desvio mandibular da relação cêntrica para a oclusão cêntrica, a linha média dentária inferior e o pogônio devem ser comparados com outros pontos médios sagitais dentários, esqueléticos e dos tecidos moles nas posições de abertura, contato inicial e fechamento mandibular ${ }^{85}$. A oclusão cêntrica (máxima intercuspidação habitual) pode ser uma forma duvidosa de diagnóstico, pois muitos pacientes demonstram desvios mandibulares que podem mascarar ou acentuar a assimetria presente ${ }^{25}$. REBELLATO ${ }^{134}$, em 1998, comentou que a desprogramação da musculatura mastigatória com uma placa oclusal pode ser efetiva na obtenção do correto registro de mordida em relação cêntrica, antes de se realizar qualquer planejamento irreversível. A severidade da discrepância da linha média pode ser aumentada ou diminuída, dependendo de como a mandíbula se reposiciona ${ }^{134}$. Desta forma, a análise facial, o exame intrabucal e de modelos, bem como os exames radiográficos atuam na melhor elaboração da planificação do tratamento a ser implementado. Mais precisamente, a identificação do arco dentário que apresenta a assimetria facilita a previsão do número de dentes a serem extraídos ${ }^{25}$.

Desta forma, este tópico visa elucidar as várias metodologias e tecnologias disponíveis que possibilitam o diagnóstico prévio das assimetrias mandibulofaciais. Alguns comentários serão realizados quanto ao exame clínico, à avaliação das fotografias e à análise dos modelos. Além da citação de trabalhos que utilizaram as seguintes radiografias: ortopantomográfica, telerradiografia lateral, submentoniana, póstero-anterior, oblíquas corrigidas ou a $45^{\circ}$ e tomografias computadorizadas.

\section{- $\quad$ Avaliação clínica, fotográfica e em modelos de estudo}

O exame clínico constitui-se na avaliação mais importante das assimetrias, porém necessita ser complementado pelas fotografias e pelo estudo dos modelos, 
apresentando o registro de mordida cuidadosamente obtido pelo arco extrabucal de transferência para se localizar as estruturas envolvidas na assimetria ${ }^{85}$.

Em 1931, SVED ${ }^{165}$ considerou que o simples exame visual direto pode ser mais preciso do que um bom método científico para o reconhecimento das assimetrias faciais. MOORE; HUGHES ${ }^{111}$, em 1942, utilizaram a observação direta para analisar seus pacientes na cadeira odontológica. Apesar de CAMPBELL ${ }^{26}$, em 1950, ter salientado que a visão não consistia num método acurado na avaliação da assimetria facial; HERZBERG ${ }^{65}$, em 1952, afirmou que provavelmente, a melhor maneira de desenvolver a habilidade na avaliação das faces consistia numa observação direta, criteriosa e repetida, sendo este autor quem primeiro introduziu as fotografias no estudo das faces. Ainda neste mesmo ano, GAVAN; WASHBURN; LEWIS $^{47}$, afirmaram que se os pontos anatômicos fossem marcados nas faces, muitas medidas poderiam ser calculadas precisamente por meio das fotografias dos pacientes. As fotografias faciais e intrabucais constituem-se instrumentos indispensáveis para a documentação das condições iniciais, bem como para o estabelecimento da lista de problemas e do planejamento, sendo essenciais também na avaliação dos resultados do tratamento ${ }^{85}$.

A análise facial consiste num método de grande valia na detecção das alterações das estruturas faciais. O deslocamento superior do ponto orbitário, a altura e o deslocamento lateral do processo malar, a altura do ramo mandibular, os deslocamentos do ângulo mandibular e lateral do mento (em oclusão e em repouso) e a altura dentária maxilomandibular podem ser verificados no exame frontal. $\mathrm{Na}$ vista inferior da face, devem ser visualizadas a rotação e o comprimento do corpo mandibular, a rotação do palato e o deslocamento posterior do processo malar. $O$ exame frontal, inferior ou do perfil do paciente pode ser realizado diretamente ou com fotografias apropriadas. Estas avaliações faciais do tecido mole assemelhamse às avaliações esqueléticas realizadas nas radiografias ântero-posterior e submentoniana, respectivamente. Entretanto, a avaliação inferior da face dificilmente é utilizada, porém auxilia na estimativa das assimetrias faciais, especialmente as rotações e os deslocamentos ântero-posteriores ${ }^{33}$. 
As fotografias da face consistem num ótimo recurso auxiliar na determinação da assimetria ${ }^{173}$. Nas avaliações de perfil, pode-se utilizar o plano horizontal de Frankfürt e a linha vertical da glabela, superpostos na fotografia para avaliar a presença de desequilíbrio. As diferenças entre os perfis direito e esquerdo são características de assimetrias e podem ser expressas como diferenças na distância vertical dos ângulos goníacos do plano horizontal de Frankfürt, nas posições ânteroposteriores dos ângulos goníacos e dos processos malares e assim por diante ${ }^{32}$. Na avaliação frontal, o plano de Frankfürt, o plano sagital mediano (N-ENA) e o orbitário são demarcados na fotografia. Os lados direito e esquerdo são examinados para determinar assimetrias vertical ou lateral dos olhos, orelhas, processos malares, ângulos goníacos, pório, proeminência do mento e das partes dentofaciais relacionadas ${ }^{32}$.

Utilizando pontos determinados a partir da rafe palatina mediana em modelos de estudo, concluiurse que não havia diferença sistemática bilateral entre os lados direito e esquerdo no arco superior ${ }^{68}$. A rafe palatina mediana poderia ser considerada a linha de referência média mais confiável, devendo os modelos de gesso serem recortados, posteriormente, de modo a formar um ângulo de 90, com a rafe. Desta forma, a posição ântero-posterior de cada um dos quatro quadrantes dentários pode ser estudada para a detecção do segmento do arco que ocasiona a Classe II unilateral ${ }^{173}$. A utilização de um instrumento denominado simetroscópio para se estudar a simetria dos arcos dentários constitui-se num recurso simples e de fácil confecção para a determinação da assimetria dentária. Na avaliação dos casos de Classe II, subdivisão, verificou-se que o arco superior no lado da Classe II pode ser encontrado mais anteriormente ou, o inferior mais posteriormente, ou uma combinação de ambas as posições anormais ${ }^{173}$.

Pela análise dos modelos, podem ser determinadas as diferenças significantes dos arcos dentários. Para tanto, a porção distal da papila palatina e a borda posterior da rafe palatina próximo à fóvea centralis no arco superior podem ser utilizadas, transferindo estes dois pontos para o modelo inferior. As pontas de cúspides vestibulares dos dentes posteriores e os pontos incisais médios dos dentes 
anteriores são marcados nos modelos a lápis. Medidas lineares podem ser realizadas em cada um dos sete pontos bilaterais dentários na direção transversal até a rafe palatina mediana. O mesmo procedimento deve ser feito para computar os índices ântero-posteriores dos segmentos anteriores e vestibulares das assimetrias. Os desvios de linha média são avaliados por medidas lineares do ponto médio entre os incisivos centrais até a linha da rafe palatina mediana, realizando-se de modo análogo nos modelos inferiores ${ }^{1}$. Além disso, os modelos podem ser recortados com as superfícies distais num mesmo plano e perpendiculares a três pontos marcados na rafe palatina mediana ${ }^{97,98}$ para a análise das assimetrias dentárias referentes às posições dos molares.

O exame dos modelos promove uma melhor visão tridimensional do relacionamento dentário do que o exame clínico. A avaliação de cada arco dentário e de seus quadrantes devem ser examinados nos modelos de gesso, nos oclusogramas e/ou pela simetroscopia para se determinar precisamente a assimetria intra e interarcos. A assimetria do arco dentário pode ser resultante da rotação completa da maxila ou mandíbula. O diagnóstico deste deslocamento rotacional maxilar pode requerer uma avaliação cuidadosa com montagem dos modelos de estudo em um articulador anatômico semi-ajustável. Finalmente, os modelos montados e a predição do traçado cirúrgico constituem elementos essenciais no tratamento de pacientes que requerem a correção cirúrgica-ortodôntica das assimetrias faciais ${ }^{85}$.

\section{- Radiografia Ortopantomográfica e Cefalograma Lateral}

As técnicas radiográficas permitem a verificação da extensão do envolvimento do tecido esquelético subjacente. Nas assimetrias clínicas, uma avaliação radiográfica pode revelar uma base esquelética assimétrica em maior ou menor grau. A radiografia panorâmica consiste num instrumento valioso para o estudo das estruturas dentárias e ósseas da maxila e mandíbula. A presença de várias entidades patológicas, dentes perdidos, supranumerários e a obstrução das vias aéreas podem ser detectadas. O contorno, o formato e o tamanho da borda inferior 
da mandíbula, o ramo e os côndilos podem ser avaliados e comparados bilateralmente ${ }^{85}$.

A distorção e a magnificação imprevisíveis da imagem da radiografia panorâmica limitam a precisão da sua informação. Entretanto, há a possibilidade de se detectar a assimetria mandibular, como as diferenças na forma e posição condilar entre os lados direito e esquerdo, as diferenças entre a altura e a largura do ramo entre os dois lados, o grau de chanfradura antegoniana bilateral, a quantidade de desenvolvimento do corpo mandibular de ambos os lados, o desvio do ponto médio mandibular, a presença ou ausência de processo coronóide e a abertura do ângulo goníaco $^{123,140}$.

As radiografias panorâmicas, apesar de serem pouco precisas e confiáveis, servem para avaliar o espaço disponível no segmento póstero-superior antes de se implementar uma mecânica de movimentação distal do molar. A aplicação de forças de distalização, por meio de aparelhos removíveis, do expansor tipo pêndulo, das molas de distalização, da ancoragem extrabucal, do jasper jumper e do preparo de ancoragem com degraus distais, necessitam da confirmação da presença de espaço suficiente na região póstero-superior detectado pelas radiografias periapicais e ortopantomográficas $^{155}$.

Os cefalogramas laterais proporcionam informações valiosas, quanto às assimetrias verticais, por mostrarem falhas nas estruturas bilaterais, como as superposições dos dentes posteriores e das bordas inferiores direita e esquerda da mandíbula. Entretanto, deve-se ter certeza quanto à correta posição da cabeça, particularmente se os condutos auditivos encontram-se em diferentes níveis ${ }^{85}$.

\section{- Radiografia Submentoniana}

A radiografia submentoniana apresenta grande potencial para a avaliação das assimetrias quando comparada à póstero-anterior por permitir que pontos anatômicos na base do crânio, que se encontram distantes dos ossos da face, sejam utilizados para a determinação do eixo sagital mediano ${ }^{46}$. 
Em 1905, SCHUELLER ${ }^{147}$ descreveu pela primeira vez a radiografia submentoniana e mais tarde, MERRILL ${ }^{105}$, em 1949, reapresentoura.

Investigando sobre a precisão da radiografia submentoniana, GILBERT ${ }^{51}$, em 1960, utilizou um filme radiográfico paralelo ao plano horizontal de Frankfürt e perpendicular ao solo. Utilizou um aparelho de $\mathrm{Rx}$ que produzia $140 \mathrm{Kvp}$, para a obtenção de uma imagem nítida, sendo que o feixe de raios $X$ incidia no vértice do crânio. Este método foi considerado bastante útil na avaliação das assimetrias esqueléticas e nas deformações associadas às fissuras labiopalatais, apesar de nenhuma análise cefalométrica ter sido proposta. Apresentou também grande precisão para as mensurações de largura, entretanto, erros significantes foram encontrados nas medidas de comprimento das estruturas ${ }^{46}$.

Quem primeiro sugeriu a utilização da radiografia submentoniana na cefalometria foi BERGER ${ }^{12}$, em 1961, objetivando avaliar a assimetria. Para a obtenção desta projeção, determinou que a cabeça do paciente deveria estar posicionada num cefalostato, com o plano de Frankfürt, perpendicular ao solo. A distância entre o tubo e o filme deveria ser de 1,50m. Para a orientação da avaliação das estruturas anatômicas, demarcou e traçou diversos pontos, linhas e planos. O ponto buccale foi localizado na região anterior da superfície interna do arco zigomático e o ponto angulare, na ponta de uma densa área radiopaca de forma triangular, formada pela união das bordas superior e inferior da órbita com o arco zigomático. Comentou que a conexão dos pontos buccale determina o plano buccale que passa pelos primeiros molares superiores, enquanto que a conexão do pontos angulare determina o plano angulare que corta o arco dentário entre os caninos e pré-molares. O plano condilar passa pelos contornos mais distais de cada côndilo. Para a determinação de uma linha média sagital, BERGER ${ }^{12}$ utilizou, como orientação, os seguintes pontos: crista galli, crista frontalis, vômer, tubérculo do atlas, processo odontóide e crista occipital interna. Como a simetria absoluta do crânio consiste numa situação muito rara, não foi possível traçar uma linha reta unindo todos esses pontos, tornando-se necessária alguma interpolação. Para completar o sistema de coordenadas, foi utilizada uma linha, perpendicular à linha 
sagital mediana, cortando-a ao meio. Estas linhas e os planos de orientação permitiam uma melhor visualização das assimetrias dentoesqueléticas das más oclusões. Entretanto, o autor não testou a reprodutibilidade e validade dessa linha de referência.

Em 1964, BERGER ${ }^{13}$ demonstrou um método para determinar a linha média da radiografia submentoniana, desenhando uma linha passando pelo vômer, pela parte posterior do septo nasal e pela crista galli. Afirmou que a radiografia submentoniana poderia ser utilizada simultaneamente com as projeções lateral e frontal para a análise das deformidades dentofaciais. Sugeriu que a linha média basilar uma vez construída poderia ser utilizada no estudo da assimetria facial.

NAHOUM; FIASCONARO; DI SALVO ${ }^{115}$, ainda neste ano, afirmaram que a radiografia submentoniana poderia ser incorporada na análise tridimensional das deformidades cranianas, especialmente quando as assimetrias não são detectadas em projeções laterais comuns. Além disso, asseguraram que a radiografia basilar relaciona os dentes, bem como a maxila e a mandíbula com o esqueleto craniofacial.

O trabalho de MOSS; SALENTIJN ${ }^{112}$, em 1971, concluiu que a passagem e a localização dos feixes neuromusculares não podem ser violados durante 0 crescimento. Para tanto, basearam-se nos estudos da estabilidade e homogeneidade da localização do forame mentoniano que serviram de referência para o forame oval como pontos de construção para o eixo de referência sagital mediano. Advogaram que a radiografia submentoniana deve ser tomada com a cabeça posicionada de tal forma que o plano de Frankfürt esteja paralelo ao plano do filme e o plano sagital mediano pode ser derivado dos forames na base craniana. Em avaliações radiográficas de uma série relativamente grande de crânios em idades dentárias variadas, com implantes colocados no forame oval, mandibular e mentoniano, revelaram que suas posições foram estáveis durante o crescimento.

Em 1979, MARMARY; ZILBERMAN; MIRSKY ${ }^{96}$ avaliaram a confiabilidade na construção de uma linha de referência média, usando os forames espinhosos como 
pontos de referência, pela vista basilar, para o estudo da assimetria. Radiografias submentonianas de 86 crânios secos foram realizadas, obtendo-se uma linha média em cada traçado, da seguinte forma: os centros dos forames espinhosos foram unidos e uma linha perpendicular foi traçada para servir como linha média, mensurando-se várias estruturas pareadas e não pareadas até essa linha média. Os desvios médios de cada ponto estavam dentro dos limites do erro de medição. A reprodutibilidade dessa técnica foi conferida por meio de um segundo traçado de oito radiografias selecionadas aleatoriamente. Concluíram que esta linha média vertical, construída perpendicularmente à linha horizontal formada pelos forames espinhosos, realmente assemelha-se ao plano sagital mediano, apresentando grande confiabilidade na avaliação do grau de assimetria presente em radiografias submentonianas. Afirmaram que estes forames permaneceriam constantes durante o período de crescimento e desenvolvimento craniofacial.

Poucos trabalhos têm relatado sobre o desenvolvimento da radiografia basilar como método de diagnóstico na avaliação e tratamento dos pacientes com anomalias craniofaciais. Em 1985, GRAYSON et al. ${ }^{54}$ objetivaram aplicar o método de traçado cefalométrico multiplanos ${ }^{53}$, utilizando a radiografia submentoniana e discutindo sua participação no diagnóstico e plano do tratamento ortodôntico. Nesta análise, o cefalograma foi traçado três vezes, definindo-se os pontos e as estruturas de três planos basilares e apresentando as instruções para o seu traçado. Afirmaram que este método auxilia no reestabelecimento do relacionamento tridimensional que existe nos filmes radiográficos com duas dimensões. Descreveram também um método para orientar a construção da linha média ânteroposterior de estruturas da base craniana. Esta linha média construída foi transportada para cada plano, sendo crítica para relacionar a localização e extensão da deformidade craniana na análise tridimensional. Neste trabalho, a análise cefalométrica basilar foi aplicada para o estudo de um indivíduo normal e de três pacientes com anormalidades craniofaciais, tais como o hipertelorismo orbital, a sinostose craniofacial e a microssomia hemicraniofacial. Para cada caso, a análise cefalométrica foi aplicada e os resultados radiográficos discutidos. Concluíram que 
os traçados pré-cirúrgicos nas radiografias basilares podem ser manipulados para simular as alterações esqueléticas previstas na cirurgia, como nas telerradiografias.

ARNOLD; ANDERSON; LILYEMARK ${ }^{5}$, em 1994, utilizaram a radiografia submentoniana para avaliar 44 adultos, com a análise de assimetria desenvolvida por RITUCCI; BURSTONE ${ }^{136}$, em 1981, e publicada por FORSBERG; BURSTONE; HANLEY ${ }^{46}$, em 1984. Comentaram que esta análise de assimetria consiste na utilização de pontos anatômicos bilaterais, criando sistemas de coordenadas de referência que podem ser utilizados para avaliar outros pontos. Três componentes foram analisados: a base do crânio, o complexo zigomaticomaxilar e a mandíbula e cada componente apresentava estruturas que eram analisadas quanto à assimetria, em relação ao sistema de referência do forame espinhoso, assim como em relação ao sistema de referência na linha média, originário daquele componente. Os côndilos também foram analisados em relação ao eixo intercondilar (um eixo médio de referência derivado da própria mandíbula) para determinar sua posição simétrica em relação à mandíbula. Esse sistema de análise permite estabelecer se a mandíbula está assimetricamente posicionada em relação à base craniana, ou se a estrutura mandibular apresenta uma forma assimétrica. Portanto, a base craniana apresentou medidas de assimetria realizadas em relação ao sistema de coordenadas de referência mediosagital, derivado dos forames espinhosos bilaterais. O complexo zigomaticomaxilar utilizou a linha transpterigomaxilar e sua bissetriz perpendicular como linha de referência mediosagital para medir a assimetria na região facial média ${ }^{5,46}$. Finalmente, a mandíbula apresentava um sistema de referência de coordenadas baseado na linha transcondilar e sua bissetriz perpendicular, para medir a assimetria dentro da mandíbula ${ }^{5,46}$. Diversas estruturas pareadas e não pareadas foram então avaliadas por comparação com esse sistema de coordenadas. Mensuraram a distância até as linhas médias, para as estruturas bilaterais, enquanto as diferenças foram calculadas e, para as estruturas não pareadas, mediram a distância até o plano sagital médio. 


\section{- $\quad$ Radiografia Póstero-Anterior (PA)}

A assimetria diz respeito a uma variação na morfologia dos lados direito e esquerdo, sendo o exame em norma frontal, o método mais utilizado para a avaliação da assimetria craniofacial, pois compara o grau e a localização do problema esquelético, servindo, também, para a aferição das discrepâncias transversais. Entretanto, sua maior desvantagem encontra-se na localização dos pontos relacionados. Para o esclarecimento desta questão, alguns autores ${ }^{81,142}$ descreveram pontos facilmente identificáveis pela radiografia póstero-anterior, que foram: os contornos lateral e superior da órbita, a crista galli, o ponto gônio, a base craniana anterior e a asa menor do osso esfenóide.

JACKSON $^{71}$, em 1937, afirmou que a determinação do plano sagital mediano do crânio, em estudos com a radiografia PA, é complexa e nem sempre possível. Para tanto, alguns trabalhos procuraram aperfeiçoar este método de avaliação, propondo diferentes metodologias. Em 1951, HARVOLD ${ }^{57}$ conduziu diversos estudos de simetria do esqueleto facial, desenvolvendo o método da linha-X para estabelecer o plano sagital mediano. Esta linha foi construída por meio de uma perpendicular à linha horizontal que conecta as suturas frontozigomáticas direita e esquerda, passando pelo ápice da crista galli. Sua amostra consistia de 80 crânios secos, com idades variando dos três aos 20 anos. Determinou que freqüentemente a espinha nasal anterior estava muito próxima à linha-X $(<1,5 \mathrm{~mm})$ em mais de $90 \%$ das radiografias. Além disso, as distâncias foram medidas da linha-X aos lados das bordas temporais do osso zigomático e da sutura zigomaticomaxilar, no processo malar. O índice de simetria determinado por estas análises nas radiografias PA foi muito próximo dos resultados antropológicos realizados diretamente em crânios secos. Concluiu que era possível identificar com o auxílio da radiografia frontal, assimetrias do esqueleto facial com um considerável grau de precisão.

Conduzindo um estudo realizado em radiografias póstero-anteriores, SHORE ${ }^{154}$, em 1959, calculou vários graus de assimetria facial em humanos com oclusão normal e má oclusão. Propôs um método utilizando pontos facilmente 
discerníveis para construir dois pontos faciais médios e produzir uma linha de referência média facial nesta radiografia. O ponto 1 foi definido como ponto médio entre os aspectos mediais das órbitas, no nível do plano esfenóide e o ponto 2 foi determinado pelas estruturas anatômicas do nariz, projetando-se linhas tangentes às bordas laterais da parede nasal e perpendiculares ao eixo do cefalostato. As duas projeções foram interceptadas por uma linha tangente ao ponto mais inferior de cada uma das cavidades nasais e a distância entre as intersecções foi dividida ao meio para formar o ponto 2 .

MULICK ${ }^{114}$, em 1965, descreveu uma técnica para a obtenção de radiografias PA para utilização no diagnóstico ortodôntico. Durante o traçado anatômico para orientação no sentido horizontal, recomendou a utilização do eixo transporiônico, do eixo que passa pelos forames redondos ou do eixo das suturas frontozigomáticas direita e esquerda. Já no sentido vertical, a linha de referência pode ser construída de duas maneiras: 1- como uma perpendicular a qualquer um dos 3 eixos horizontais, passando pelo maior número de estruturas anatômicas centrais e 2 como uma linha vertical absoluta, passando pelo maior número de estruturas anatômicas centrais. As estruturas anatômicas centrais referem-se à crista galli, sutura palatina mediana e vômer. As aplicações das radiografias PA consistem na avaliação de desvios de linha média, inclinação do plano oclusal, assimetria facial, desvios funcionais da mandíbula, tipologia mandibular, avaliações dentárias e análises de deformidades faciais.

A técnica de se utilizar as olivas metálicas para determinar as posições dos centros dos meatos apresenta precisão duvidosa, pois podem haver diferenças na espessura nos dois meatos e na compressibilidade dos tecidos moles sobre os mesmos. Em 1968, SUTTON ${ }^{164}$ afirmou que a utilização dos meatos para estabelecer pontos fixos para se determinar o eixo transverso do crânio torna-se incrédulo devido à sua estrutura. Isto ocorre em função do desnível vertical e da posição mais a frente de um meato em relação ao outro. Também, como as extremidades das olivas podem não preencher os meatos, é possível que o paciente apresente ligeira rotação ou inclinação da cabeça. 
A avaliação da assimetria facial na radiografia $P A$, utilizando triângulos bilaterais objetiva determinar diversos pontos localizados nas radiografias e uma linha média determinada para a maxila e a mandíbula, separadamente. $\mathrm{O}$ eixo $\mathrm{X}$ (linha média do terço médio da face) pode ser delineado a partir de uma linha traçada do mentoniano, pelas bissetrizes das linhas que unem os pontos bilaterais condilares e goníacos. Considera-se o ângulo de divergência entre essas duas linhas como sendo o grau de assimetria entre a maxila e a mandíbula. A bissetriz destes dois eixos pode $æ r$ arbitrariamente definida como o eixo facial. Para a avaliação da assimetria das várias partes componentes da face, deve-se utilizar um método de construção de triângulos bilaterais, totalizando sete, sendo construídos para esta avaliação, com a área de cada um calculada para determinar a assimetria relativa de cada parte componente da face ${ }^{172}$.

Uma análise cefalométrica tridimensional com multiplanos foi proposta por GRAYSON; MCCARTHY; BOOKSTEIN ${ }^{53}$, em 1983, objetivando a visualização das linhas médias esqueléticas em níveis progressivos de profundidade do complexo craniofacial por meio de quatro traçados das radiografias PA. Esta técnica demonstrou um conceito tridimensional das deformidades do esqueleto craniofacial, proporcionando informações de diagnóstico muito úteis ao clínico, permitindo que a severidade da assimetria fosse avaliada de posterior para anterior e vice-versa. Estes dados podem ainda auxiliar na formulação do prognóstico, assim como na determinação da área onde a cirurgia pode ser realizada, caso seja necessária. A aplicação de uma fórmula matemática a um sistema biológico, como no cálculo das áreas dos triângulos direito e esquerdo na radiografia, não deve ser realizada, sendo mais válido observar as diferenças, em forma e posição, desses triângulos construídos bilateralmente.

A análise cefalométrica póstero-anterior foi desenvolvida com o intuito de fornecer informações clínicas relevantes sobre as localizações específicas e as dimensões das assimetrias faciais. Em 1987, GRUMMONS; VAN DE COPELLO ${ }^{55}$ apresentaram uma análise de assimetria frontal que consistia na construção de quatro linhas horizontais de referência para mostrar os diversos níveis de 
paralelismo das estruturas faciais. A linha de referência média sagital (LRM) foi traçada a partir da crista galli, tangenciando a espinha nasal anterior (ENA) até a região mentoniana, perpendicular ao plano horizontal (plano Z) que conecta as suturas frontozigomáticas. Consideraram a LRM como referência, pois se aproxima do plano visual formado pelo subnasal e os pontos médios entre os olhos e as sobrancelhas. A morfologia mandibular foi avaliada por meio de triângulos bilaterais a partir do côndilo, das chanfraduras antegonianas e do mentoniano e a comparação da assimetria maxilomandibular foi avaliada por meio de pares de triângulos. Concluíram que esta análise fornece um método prático e funcional de determinação da localização e quantidade de assimetria facial, apresentando grande valor clínico quando integrada com as informações das radiografias em norma lateral e submentoniana.

Em 1993, FERGUSON ${ }^{42}$ comentou sobre um outro método de mensuração das assimetrias por meio de radiografias frontais. Sua técnica baseava-se na utilização de uma linha de referência horizontal determinada nas margens superiores orbitárias e uma linha de referência vertical, no plano sagital mediano, construída em ângulo reto à linha supra-orbitária, passando pela crista galli. Determinou a assimetria esquelética neste trabalho pela medição dos ângulos entre o plano sagital mediano e uma linha da crista galli à ENA e outra linha da crista galli ao mentoniano.

Radiografias póstero-anteriores também podem ser obtidas com o plano de Frankfürt paralelo ao plano horizontal e a mandíbula na posição do primeiro contato oclusal. O plano médio sagital pode ser construído por uma linha vertical, conectando o centro da crista galli e o centro da espinha nasal anterior, estendendose até a mandíbula, avaliando-se a assimetria mandibular em relação a esta linha 160 .

Além de permitir o diagnóstico das más oclusões assimétricas, os cefalogramas frontais são úteis na avaliação da mordida cruzada posterior, auxiliando também na diferenciação da mordida cruzada esquelética, decorrente da atresia do palato, da mordida cruzada dentária devido à inclinação axial anormal do 
molar. Para a visualização da inclinação axial dos molares no plano frontal, uma linha horizontal pode ser desenhada ao longo das cúspides, conectando os molares direito e esquerdo do arco, comparando-se, posteriormente as inclinações axiais dos dois molares ${ }^{155}$.

A radiografia cefalométrica póstero-anterior constitui-se num recurso valioso para comparação das estruturas direita e esquerda da face, pois se encontram numa distância relativamente semelhante do filme e da fonte radiográfica. Podem ser obtidas em oclusão cêntrica, bem como em posição de repouso. Com a utilização de dois filmes radiográficos, pode-se determinar a extensão de um possível desvio funcional ${ }^{85}$.

A maioria dos ortodontistas ainda resiste quanto à solicitação da radiografia frontal devido às suas desvantagens. Esta técnica radiográfica parece dificultar a reprodução da postura da cabeça do paciente, na padronização de radiografias frontais subseqüentes, tornando-se limitada a sua utilização na clínica diária. Outra razão diz respeito à complexidade na identificação dos reparos anatômicos devido à superposição das estruturas, além da pobreza da técnica radiográfica. Por estas razões, outras técnicas radiográficas adicionais podem ser também utilizadas para avaliar a assimetria facial, como as radiografias oblíquas e as submentonianas ${ }^{55}$.

\section{- Radiografias Cefalométricas Oblíquas a 45 e Corrigida}

A mensuração da diferença entre os comprimentos mandibulares direito e esquerdo pode ser realizada pela radiografia oblíqua, devendo a projeção dos feixes de raios $X$ ser dirigida a $45^{\circ}$, em relação ao plano sagital mediano. A cabeça do paciente deve ser orientada de maneira que o plano de Frankfürt fique paralelo ao solo. A projeção oblíqua pode medir o comprimento mandibular bilateral ${ }^{27}$ e também mensurar a altura vertical do corpo mandibular e a altura dentoalveolar dos dentes de ambos os lados da mandíbula ${ }^{130}$. Além disso, avalia a assimetria da morfologia condilar e dos ramos direito e esquerdo, assim como, a pneumatização do processo mastóide, a forma da fossa glenóide, o ângulo goníaco (forma e posição de ambos 
os lados e forma da borda inferior da mandíbula) e a altura vertical do plano oclusal em relação ao desenvolvimento vertical dos processos alveolares. A medição do comprimento alveolar na radiografia oblíqua requer a identificação de dois pontos: a sínfise e o côndilo. O ponto sínfise consiste no ponto médio da borda inferior da mandíbula, na região da sínfise, considerado um ponto confiável uma vez que esta região da mandíbula parece ser estável ${ }^{184}$. A radiografia póstero-anterior pode facilitar a localização deste ponto, pelo exame do contorno da sínfise, relacionando-a à radiografia oblíqua. Ainda mais, a identificação das raízes dos incisivos e caninos, permite demarcar este ponto no meio das raízes dos incisivos centrais. Na porção externa mais distal e posterior da cabeça condilar está o ponto condílio e a determinação do comprimento mandibular consiste em se medir a maior distância do ponto sínfise ao condílio, com uma precisão de $0,5 \mathrm{~mm}$.

Utilizando radiografias oblíquas e laterais, HATTON; GRAINGER ${ }^{60}$, em 1958, avaliaram 15 jovens de três anos de idade. Realizaram os traçados das radiografias duas vezes, investigando um ponto de mensuração na telerradiografia e dois, na radiografia oblíqua direita, sendo uma medida vertical (altura do molar) e uma horizontal, medida mesiodistal mandibular, que conectava a distal do molar à mesial do canino. Testes estatísticos foram utilizados para avaliar as variações nos traçados e nas técnicas radiográficas e concluíram que os erros podem ser considerados desprezíveis em comparação às diferenças entre os pacientes.

Em 1961, BARBER; PRUZANSKY; KINDELSPERGER ${ }^{8}$ avaliaram a confiabilidade das medidas obtidas na radiografia oblíqua a 45ํㅡ em 10 crânios. Utilizaram marcadores de prata em 11 locais de cada metade da mandíbula e em oito locais de cada metade da maxila, permitindo a identificação destas áreas para posterior mensuração nos traçados. Realizaram-se 14 medidas mandibulares e 12 medidas maxilares nas radiografias oblíquas direita e esquerda e diretamente no crânio. As medidas nas radiografias, considerando o fator de magnificação, foram utilizadas para se calcular a predição das medidas realizadas diretamente no crânio. Concluíram que as medidas calculadas correlacionavam-se com as medidas reais em centésimos de milímetros na maioria delas e variaram não mais que $0,3 \mathrm{~mm}$ em 
qualquer medida. Mencionaram que esse pequeno grau de variação entre as medidas indicou boa confiabilidade das medições realizadas na projeção oblíqua.

Anos mais tarde, WOODSIDE ${ }^{183}$, em 1990, comentou que a medida dos comprimentos mandibulares nos cefalogramas oblíquos seria imprecisa. Afirmou que ao avaliar pacientes cirúrgicos, apresentando assimetria mandibular por meio de radiografias oblíquas a 45ำ, pode-se verificar grandes diferenças nas mensurações dos comprimentos mandibulares direito e esquerdo. Entretanto, quando se utiliza a radiografia submentoniana para a avaliação da posição mandibular, verificou-se que para estes casos, a angulação correta da projeção oblíqua raramente é de 45ํ․ Explicou que o mento encontra-se geralmente desviado para o lado em que o comprimento mandibular está mais curto, resultando em diferença significante entre a relação dos planos mandibulares direito e esquerdo e o plano do filme, podendo assim alongar e aumentar a imagem subseqüente. Afirmou que a posição do plano mandibular em relação ao plano do filme deve ser ajustada para a obtenção de uma medida mais precisa, utilizando-se radiografias submentonianas.

Objetivando eliminar as imprecisões das radiografias oblíquas a $45^{\circ}$, em casos com assimetrias acentuadas, METAXAS ${ }^{106}$, em 1993, desenvolveu e testou o método da radiografia oblíqua corrigida, visando aumentar a precisão da medição do tamanho da mandíbula em ambos os lados. Para tanto, afirmou que se deve realizar inicialmente a radiografia submentoniana para que a determinação do ângulo entre o corpo mandibular e o eixo transporiônico, dos lados direito e esquerdo. Comentou que após a obtenção destes ângulos, obtêm-se radiográficas oblíquas corrigidas, de cada lado individualmente, em vez de se utilizar o ângulo médio de 45ํ․ Verificou que este procedimento proporciona uma maior precisão da medição do comprimento mandibular. Desta forma, o autor estudou um crânio seco com vários graus de assimetria criados na mandíbula, objetivando avaliar e comparar os comprimentos mandibulares medidos nas radiografias oblíquas corrigidas, com os valores reais medidos diretamente no crânio seco. Colocou parafusos no corpo e ramo do lado esquerdo da mandíbula de maneira a simular 15 tipos de assimetrias. Radiografias oblíquas direita e esquerda foram obtidas para cada grau de assimetria mandibular, 
objetivando mensurar o comprimento mandibular em cada filme. Utilizou implantes no condílio e na sínfise, assim como em outros pontos, criando marcadores radiopacos nos filmes, eliminando-se a variabilidade nas medidas do comprimento mandibular. Realizou-se três repetições das medidas do comprimento mandibular para o teste intra-examinador, visando avaliar a precisão da metodologia empregada nesta pesquisa. Avaliou-se, também, as medidas calculadas e reais dos comprimentos mandibulares esquerdo e direito, nas 15 assimetrias simuladas. Concluiu-se que todas as medidas estavam dentro do padrão de precisão satisfatório e que para todas as assimetrias, a diferença entre os valores calculados e reais era menor que $1 \mathrm{~mm}$, demonstrando uma alta correlação neste estudo. Utilizando o centro geométrico dos lados mandibulares, GIAMBATTISTIN ${ }^{48}$, em 1997, avaliou a precisão da radiografia oblíqua corrigida, encontrando um valor menor do que foi verificado por METAXAS ${ }^{106}$. Isto decorreu devido à sua metodologia não ter utilizado a linha que passa pelos pontos médios condilares até o centro da sínfise mentoniana, apresentando resultados diferentes em sua pesquisa.

\section{- $\quad$ Tomografia Computadorizada (TC)}

Pelo fato de uma grande porcentagem de assimetrias dentofaciais envolverem a mandíbula, geralmente necessita-se da obtenção de um maior número de imagens da (ATM) articulação temporomandibular ${ }^{85}$. As tomografias convencionais, utilizadas na odontologia, devem ser realizadas dos lados direito e esquerdo do paciente, em máxima intercuspidação habitual ${ }^{84,116}$, mostrando objetos dispostos num plano de interesse distinto das estruturas anatômicas envolvidas ${ }^{85}$. Através dos parâmetros técnicos que geram o controle da distorção das estruturas acima e abaixo do plano de interesse, estruturas anatômicas podem ser visualizadas sem a superimposição percebida em outros tipos de radiografias. Embora as tomografias geralmente sejam mais preferidas do que as transcranianas e transfaringeanas, elas não podem ser diagnosticáveis, particularmente quando suspeita-se de desarranjos internos da $\mathrm{ATM}^{85}$. Os cortes tomográficos computadorizados da ATM, atualmente, mostram claras imagens dos tecidos esqueléticos. As vantagens são os múltiplos cortes obtidos com uma única 
escanerização, além do potencial da imagem dos tecidos moles. Considera-se a quantificação da radiação baixa para as múltiplas imagens da articulação que podem ser vistas nos cefalogramas frontais e laterais durante o mesmo escaneamento. A visualização dos tecidos moles da ATM, particularmente o disco, pode ser aumentada pela injeção de material de contraste dentro do espaço articular previamente à realização das tomografias ${ }^{85}$.

Imagens extremamente precisas dos tecidos moles e duros da ATM tornamse possíveis, requerendo radiação não ionizante. A ressonância magnética constitui-se num recurso não disponível no diagnóstico das formas do processo degenerativo e adaptativo osteocartilaginoso, bem como da osteoartrite, necrose avascular e remodelação regressiva envolvendo a ATM de pacientes com assimetrias faciais ${ }^{85}$.

Objetivando alcançar resultados estéticos e funcionais favoráveis no tratamento da assimetria facial, um diagnóstico adequado baseado em informações detalhadas torna-se essencial para o plano de tratamento ortodôntico-cirúrgico combinado. Para os casos mais severos, imagens escanerizadas e reconstruções tridimensionais da tomografias computadorizadas promovem mais informações do que as técnicas radiográficas convencionais para a análise do padrão individual. Combinando-se técnicas apropriadas de diagnóstico, há um melhor prognóstico das metas mais aceitáveis de tratamento para os pacientes com assimetrias ${ }^{85}$.

\section{6 - Modalidades de tratamento da Classe II, subdivisão}

A literatura ortodôntica encontra-se repleta de informações concernentes à má oclusão de Classe II e seu tratamento. Fatos e idéias a respeito deste tipo de má oclusão têm sido categorizados em tópicos distintos, guiando o diagnóstico, plano e mecânica de tratamento, contenção e, finalmente, a estabilidade dos resultados $^{173}$. O plano de tratamento, a correção e a contenção da Classe II subdivisão apresentam dificuldades, necessitando de uma proposta de planejamento e diagnóstico adequados, condição sine qua non para qualquer sucesso clínico ${ }^{173}$. 
O diagnóstico da assimetria realmente exerce suma importância no planejamento dos casos. A maioria das discrepâncias de linha média são causadas por assimetria esquelética e quando não diagnosticadas, estas assimetrias podem aparecer novamente na fase final do tratamento ${ }^{24}$.

Há uma variedade de maneiras de se tratar a Classe II, subdivisão. Diferentes formas de tratamento podem ser empregadas, dependendo das características associadas à má oclusão, como: a severidade da discrepância ântero-posterior, sua etiologia, ou seja, se é dentária ou esquelética, a idade ${ }^{167}$ e a

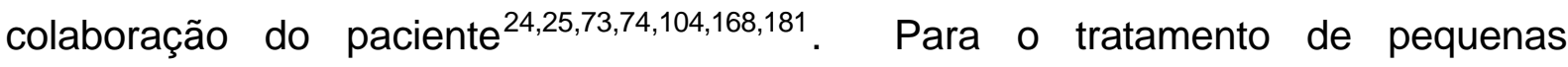
assimetrias de origem dentária, opta-se pela terapêutica assimétrica conservadora que consiste nos aparelhos extrabucais assimétricos ${ }^{181}$, nos dispositivos ortopédicos funcionais ${ }^{44,79,102,104,110,132,141,155}$ e nos aparelhos fixos associados aos elásticos de Classe $\|^{24,75,155}$ ou aos dispositivos intrabucais distalizadores ${ }^{18,35,50,155}$ sem envolver extrações. Nos casos de assimetrias dentárias severas, realizam-se as extrações assimétricas para se conseguir espaço necessário para que uma mecânica assimétrica possa ser conduzida, ou mesmo, para compensar algumas assimetrias esqueléticas $^{25,75,168}$. Entretanto, antes de se proceder com o planejamento de extração assimétrica, deve-se confirmar se realmente existe uma assimetria ou se é um desvio habitual ou funcional da mandíbula.

A utilização da ancoragem intra e extrabucal deve acompanhar o tratamento das extrações assimétricas para que se maximize a possibilidade de se realizar 0 tratamento com uma mecânica assimétrica, obtendo-se, como resultado final, uma relação simétrica dos dentes anteriores. Nos casos extremos de assimetria oclusal associada à assimetria facial, o tratamento mais adequado envolve uma combinação de ortodontia e cirurgia ortognática. Dependendo da quantidade de assimetria dentária, esquelética e facial presentes, o tratamento ortodôntico e/ou os movimentos cirúrgicos podem ser conduzidos assimetricamente, objetivando-se resultados simétricos. Entretanto, nos casos de assimetria de origem apenas esquelética, a mecânica ortodôntica pode ser simétrica, associada aos movimentos cirúrgicos destinados à correção da assimetria dentária e facial ${ }^{91}$. 


\subsection{1 - Tratamento ortopédico funcional da Classe II, subdivisão}

O sucesso do tratamento do crescimento facial assimétrico parece depender da severidade da anomalia. Entretanto, a avaliação do pré-tratamento das condições do perfil facial tegumentar e das bases apicais e suas mudanças durante o crescimento mostraram que a hipofunção muscular pode ser significantemente compensada durante a terapia ortopédica. Além disso, convém mencionar que os aparelhos funcionais devem ser utilizados em pacientes na fase ativa de crescimento, visando corrigir as discrepâncias ântero-posteriores, verticais e transversais pela restrição e/ou redirecionamento do crescimento das bases apicais. Entretanto, o tratamento somente com aparelhos funcionais nem sempre é eficaz, necessitando da terapia ortodôntica corretiva geralmente após a terapia funcional $^{36,63}$.

Segundo PROFFIT; VIG; TURVEY' ${ }^{132}$, em 1980, os pacientes pubescentes, que sofrem uma fratura condilar, devem se submetidos, inicialmente, ao tratamento ortopédico para estimular o crescimento condilar e o desenvolvimento dos tecidos envolvidos. Pode-se recorrer ainda aos aparelhos funcionais híbridos que amenizam as deformidades faciais, estimulando o crescimento do lado afetado.

Analisando os efeitos do tratamento com o aparelho funcional no crescimento facial, SARNAS et al. ${ }^{141}$, em 1982, analisaram um paciente com microssomia hemifacial, objetivando verificar o deslocamento da mandíbula e dos ossos maxilares, em relação ao osso frontal. As medidas foram realizadas com precisão de $0,1^{\circ}$ e $0,05 \mathrm{~mm}$. Antes do tratamento, as bases apicais estavam deslocadas para posterior e para o lado afetado pelo crescimento, aumentando o grau de retrognatia e assimetria facial. Durante o tratamento, o crescimento facial foi redirecionado e as bases apicais, deslocadas para anterior e para o lado não afetado, diminuindo o grau de retrognatia e assimetria. Entretanto, ao mesmo tempo, a inclinação da mandíbula para o lado afetado aumentou, possivelmente devido às condições morfológicas e funcionais das bases apicais, na microssomia hemifacial. A má 
oclusão dentária foi corrigida parcialmente tanto pelo deslocamento das bases apicais como pela adaptação dentoalveolar.

Demonstrando os efeitos do tratamento dos aparelhos funcionais, MELSEN; BJERREGAARD; BUNDGAARD ${ }^{104}$, em 1986, estudaram pacientes com côndilos anormais. Concluíram que a microssomia hemifacial não tratada causa a assimetria facial, progredindo durante o desenvolvimento pós-natal. A correta interação entre o músculo e o osso constitui-se na condição necessária para que ocorra a aposição óssea e conseqüente produção da simetria facial. Baseando-se nesta premissa, relataram o tratamento de três pacientes com côndilos anormais. O primeiro caso apresentava microssomia hemifacial, o segundo, fratura condilar unilateral, seguida de deslocamento e reabsorção secundária do côndilo e o último, perda bilateral de cartilagem condilar resultante de um trauma pré-pubescente. Todos foram tratados com o ativador, tendo seus resultados analisados radiográfica e clinicamente. Verificaram que o desenvolvimento de um equilíbrio muscular torna-se possível mesmo em pacientes com microssomia hemifacial, apresentando hipofunção muscular. Concluíram que a obtenção da aposição óssea para o estabelecimento de simetria ocorre se o tratamento for iniciado precocemente, pois o resultado depende do período correto de intervenção e da colaboração do paciente.

Em 1987, MONGINI; SCHMID ${ }^{110}$ utilizaram uma amostra de 11 pacientes em crescimento com uma assimetria mandibular e um desvio do mento, mostrando em todos os casos uma má oclusão com deslocamento mandibular ipsilateral em idade precoce. Radiografias póstero-anteriores, laterais oblíquas, telerradiografias e transcranianas da ATM foram obtidas em máxima intercuspidação habitual, objetivando investigar se algumas assimetrias mandibulares eram adaptações do deslocamento mandibular durante o crescimento. Nas radiografias pósteroanteriores, sete pontos foram selecionados para definir as áreas mandibular, craniana superior e craniomandibular, bilateralmente. A posição do mais alto ponto condilar dentro da fossa glenóide foi digitada e avaliada. Os dados radiográficos foram obtidos e analisados novamente após a instalação dos aparelhos funcionais e ao final de um período de observação de 37,6 meses. Radiografias controle foram 
obtidas com intervalos de seis a 12 meses, constatando-se, após o período de observação, uma melhora significante da assimetria mandibular em nove dos onze pacientes devido ao crescimento compensatório da mandíbula e do côndilo no lado afetado decorrente do deslocamento mandibular. Restabeleceram a normalização do padrão de crescimento por meio da terapia ortopédica. O avanço mandibular, promoveu um tensionamento dos músculos temporal e pterigóideo lateral, ocorrendo, conseqüentemente, uma remodelação óssea na região condilar e da fossa glenóide. Verificaram que dos 11 casos tratados, nove apresentaram uma mandíbula mais simétrica devido ao crescimento compensatório mandibular e condilar no lado ipsilateral que foi afetado devido ao deslocamento mandibular. Concluíram, portanto, que tais assimetrias devem ser tratadas pelo restabelecimento do padrão de crescimento normal.

Um ano mais tarde, MELSEN ${ }^{102}$ comentou a respeito do uso de aparelhos funcionais em pacientes com assimetria mandibular que necessitavam de cirurgia. Assegurou que a ortopedia funcional previamente à cirurgia pode evitar a assimetria secundária da maxila durante o período de crescimento, podendo estimular ou alterar o padrão neuromuscular favoravelmente de acordo com o procedimento cirúrgico.

Segundo LINDER-ARONSON ${ }^{92}$, em 1991, há vários regimes de tratamento para a microssomia hemifacial, incluindo, os aparelhos funcionais utilizados isoladamente e em conjunto com procedimentos cirúrgicos, visando melhorar a deficiência maxilomandibular; restaurar a oclusão dentária; aumentar a atividade muscular e o comprimento do ramo mandibular, tanto cirurgicamente por meio de distração osteogênica ou, gradualmente, com aparelhos ortopédicos funcionais ${ }^{30,92}$. Apesar dos objetivos do tratamento da microssomia hemifacial estarem bem definidos, uma controvérsia ainda paira a respeito de quando, como e se o procedimento cirúrgico poderia ser implementado e quando poderia ser possível estimular o crescimento mandibular por meio da terapia ortopédica funciona ${ }^{30}$. 
SCHMID; MONGINI; FELISIO ${ }^{145}$, em 1991, propuseram-se a quantificar os diferentes componentes que se relacionam com a assimetria mandibular em pacientes durante e ao final do crescimento. O grupo experimental era composto de três jovens do sexo masculino e 17 do sexo feminino, com idades entre oito a 21 anos, apresentando assimetria facial e desvio do mento. A amostra foi comparada por meio de traçados de superposição computadorizados em relação a um grupo controle de quatro jovens e um grupo de oclusão normal de cinco pacientes, sendo todos submetidos à radiografia póstero-anterior, com os dentes em máxima intercuspidação habitual. Em cada radiografia, três pontos mandibulares foram determinados (mento, gônio ou antegônio e ponto articular), além do eixo vertical de referência. Um programa de computador foi desenvolvido para avaliar o grau de simetria da mandíbula. Em dois pacientes, só o deslocamento mandibular estava presente, enquanto 14 pacientes mostraram várias características de assimetria estrutural. Os pacientes foram tratados com splints ortopédicos para manter a mandíbula numa posição de simetria. Posteriormente, um tratamento ortodôntico foi implementado até que a posição de máxima intercuspidação coincidisse com a posição de simetria. Uma nova verificação computadorizada foi realizada após um período médio de observação de 41,1 meses e o valores finais obtidos foram comparados aos iniciais ao tratamento. Em 11 pacientes, uma melhora da simetria foi observada nos dois sistemas analisados. Concluíram que, em casos de pacientes em crescimento, a assimetria craniomandibular, com desvio da mandíbula e do mento sem causa genética ou congênita ou história de trauma, infecção ou tumor pode ser resultante do deslocamento mandibular conseqüente às alterações oclusais. Se o deslocamento mandibular não é detectado e tratado precocemente, uma assimetria mandibular pode se desenvolver, tornando-se uma característica inerente na fase adulta.

HENRIQUES $^{62}$, em 1993, analisou cefalometricamente as estruturas dentoesqueléticas em pacientes com Classe II, 1a divisão numa amostra de telerradiografias em norma lateral de 75 jovens, de ambos os sexos, com idade média de dez anos, submetidos ao tratamento com o ativador associado à ancoragem extrabucal. Concluiu que houve uma restrição do crescimento maxilar e 
um crescimento mandibular significante, sem ocorrerem alterações no padrão de crescimento facial. Os incisivos superiores verticalizaram-se significantemente, enquanto os inferiores permaneceram inalterados; os molares superiores distalizaram-se e os inferiores extruíram significantemente.

O fechamento do espaço da extração no segmento posterior do arco mandibular torna-se um procedimento complexo, em qualquer circunstância, particularmente, nos casos de Classe II. Se o problema é unilateral, requerendo uma mecânica assimétrica, por não haver possibilidade de uma solução protética, pode ser ainda mais difícil estabelecer uma ancoragem tipo C, ou seja, evitar a retração dos incisivos e manter a coincidência das linhas médias ${ }^{24}$. FIORENTINO; MELSEN ${ }^{44}$, em 1996, relataram um caso clínico tratado com fechamento assimétrico do espaço da extração no segmento póstero-inferior. A paciente com 11 anos de idade apresentava uma Classe II esquelética, com os incisivos superiores apinhados e protruídos, além de uma sobressaliência de $7 \mathrm{~mm}$, uma sobremordida de $5,5 \mathrm{~mm}$ e desvio da linha média superior para o lado direito em relação à linha média facial. $\mathrm{Na}$ radiografia panorâmica, detectou-se uma agenesia do segundo pré-molar inferior esquerdo. Determinaram um avanço mandibular de $2,5 \mathrm{~mm}$ com o aparelho de Herbst que serviu como ancoragem intrabucal, monitorando a linha média, durante o fechamento do espaço do lado esquerdo. Após três meses de tratamento, ativourse mais $2 \mathrm{~mm}$, somente no lado esquerdo. Dez meses de tratamento foram suficientes para corrigir a sobressaliência, além do fechamento do espaço. O caso foi finalizado com a intrusão dos dentes ântero-superiores com o arco base e verticalização dos molares inferiores com um cantilever. Como contenção, utilizourse um ativador durante um ano, para a estabilidade dos resultados obtidos. Concluíram que esta forma de tratamento com o aparelho de Herbst possibilitou o fechamento do espaço assimétrico, sem provocar efeitos indesejáveis, em termos de assimetria, no arco dentário superior. Os diferentes níveis de força gerados pelo aparelho de Herbst nos dois lados não produziram um padrão de crescimento assimétrico na maxila, mas foi suficiente para evitar o desenvolvimento de uma assimetria do arco mandibular. 
Em 1998, KAHL-NIEKE; FISCHBACH ${ }^{79}$ propuseram-se a analisar clinicamente e por meio de tomografias computadorizadas os efeitos da intervenção ortopédica precoce em pacientes com microssomia hemifacial. Avaliaram as mudanças no tecido mole e duro da articulação temporomandibular pré e póstratamento ortopédico de cinco pacientes debilitados na região condilar. Concluíram que houve uma estabilidade e diminuição da diferença condilar esquerda e direita, além de uma melhora do volume muscular. Entretanto, um prognóstico a longo prazo não pode ser dado nos casos de deficiências musculares extremas após o crescimento ter se exaurido. Obtiveram também uma melhora na simetria facial, função mandibular, estética facial e oclusão dentária na maioria dos casos desta pesquisa. O princípio básico, na maior parte dos casos a serem tratados com aparelhos funcionais, consiste no estabelecimento de mudanças na atividade muscular para criar um novo sistema de estresse, favorecendo uma aposição óssea e uma readaptação muscular. Desta forma, nos casos simétricos, o avanço mandibular ocorre bilateralmente, enquanto que nos casos assimétricos, a indução do crescimento condilar ocorre, mais especificamente, no lado afetado. Apesar dos objetivos do tratamento da microssomia hemifacial serem bem definidos, ainda pairam dúvidas no que concerne à questão do momento ideal para se intervir cirurgicamente e também quanto à possibilidade de ocorrer a estimulação do crescimento mandibular com aparelhos funcionais.

\subsection{2 - Tratamento ortodôntico corretivo da Classe II, subdivisão}

Comumente, relacionamentos oclusais assimétricos, como uma oclusão de Classe II de um lado e uma Classe I ou Classe III, do outro, encontram-se em pacientes que procuram tratamento ortodôntico. Estes casos podem ainda apresentar uma falta de correspondência entre as linhas médias superior e inferior ou ambas as linhas médias não são coincidentes com o plano sagital mediano. As mordidas cruzadas, a forma assimétrica dos arcos, além da não coincidência dos arcos superior e inferior podem ser características de uma relação oclusal assimétrica $^{25}$. Nos casos das assimetrias dentárias, pode-se recorrer às extrações assimétricas, incluindo extração unilateral, ancoragem diferencial e mecânicas para 
o fechamento do espaço assimétrico. Nos casos sem extração, a manutenção do espaço disponível de Nance auxilia no reestabelecimento da simetria do arco. Nos casos envolvendo inclinação assimétrica e rotação do molar, uma variedade de aparelhos fixos ou removíveis podem ser utilizados, visando a correção da rotação do molar, sua verticalização e distalização para uma simetria dentro do $\operatorname{arco}^{155}$.

Desta forma, qualquer tratamento ortodôntico seja ele simétrico ou assimétrico objetiva a correção de ligeiros apinhamentos e dos desvios de linha média dentária, além da normalização da sobremordida e da sobressaliência. A finalização dos casos exige a ausência de disfunção temporomandibular, coincidência de oclusão cêntrica e relação cêntrica, paralelismo radicular e mínima reabsorção radicular.

De acordo com BURSTONE ${ }^{24}$, em 1979, a assimetria ocorre mais freqüentemente que a simetria, sendo seu diagnóstico de suma importância no planejamento. Afirmou que a maioria das discrepâncias de linha média é causada pela assimetria esquelética e muitas vezes este fator passa despercebido no plano de tratamento, provocando dificuldades na finalização dos casos. Tais assimetrias devem ser analisadas em quadrantes para que se planeje uma mecânica assimétrica detalhada, visando a correção da linha média. Além disso, considerou que, no início do tratamento, deve ser realizada a detecção de inclinações indesejáveis do plano oclusal, na vista frontal. Durante o tratamento, deve-se controlar a intrusão e a extrusão, para manter o plano oclusal nivelado corretamente. Deve-se evitar a utilização de elásticos de Classe II de um lado, de Classe III do outro e elástico cruzado anterior, pois provocam inclinações indesejáveis do plano oclusal esteticamente desfavoráveis. Nas assimetrias esqueléticas, as linhas médias da maxila e da mandíbula não coincidem, constituindo uma discrepância de linha média das bases apicais. As extrações assimétricas, com movimentações de corpo de um lado e inclinações do outro constituem-se recursos empregados na mecânica assimétrica com variação da perda de ancoragem em cada lado. Lembrou que se deve utilizar o mínimo possível elásticos unilaterais, uma vez que provocam efeitos colaterais no plano oclusal. Os oclusogramas podem ser utilizados no 
diagnóstico inicial dos casos, solucionando o problema de forma adequada e possibilitando um correto planejamento da mecânica.

SLAVICEK ${ }^{161}$, em 1988, afirmou que há uma grande quantidade de casos assimétricos e que seu diagnóstico apresenta suma importância. Quando se inicia precocemente um caso assimétrico esquelético, tem-se a oportunidade de conduzílo simetricamente. Quando se inicia o tratamento tardiamente, ou também, quando o paciente procura o ortodontista muito tarde, então deve-se estar consciente de que a terapêutica deve ser assimétrica. O complexo temporomandibular direito e esquerdo dos pacientes são diferentes, e verificourse que um grande número de casos parecem ser assimétricos. Nos casos que apresentam assimetria clínica, deve-se olhar o espaço aéreo faríngeo e a abertura nasal para ver se o lado direito e esquerdo são diferentes, avaliando-se sempre as linhas médias para a detecção de possíveis desvios. Algumas assimetrias podem ser vistas pelo exame radiográfico, quando os condutos auditivos não estão alinhados, ou quando se vê a diferença de altura do ramo e um plano oclusal oblíquo. Em alguns casos as assimetrias são verificadas em relação às diferenças entre os lados direito e esquerdo, na radiografia frontal. Finalmente, concluiu que é necessário estar ciente da presença da assimetria, especialmente a do movimento articular para se fazer um diagnóstico funcional de todos os casos assimétricos, especialmente os mais severos.

MELSEN; FIORELLI ${ }^{103}$, em 1994, desenvolveram uma mecanoterapia computadorizada, objetivando facilitar o entendimento e a aplicação da biomecânica de movimentação dentária dos casos simétricos e assimétricos. Comentaram que a interação entre o usuário e o computador vai aumentando à medida que a seqüência do aprendizado vai ocorrendo. O programa consiste de assuntos relacionados à mecânica do arco segmentado, sistema de forças, movimentação dentária, correção da sobremordida profunda, torque e inclinação, aparelhos extrabucais, oclusogramas, fechamento de espaços e, finalmente, a mecânica assimétrica. Concluíram que este programa fundamenta-se num sistema de três pilares representando o hipertexto, a multimídia e a interação, produzindo soluções biomecânicas e gerando desenhos adequados de aparelhos para cada caso. 
Em 1995, BERGAMINI; MELSEN ${ }^{11}$ afirmaram que a maioria dos casos de assimetria dentária apresenta uma história associada de perda precoce de molar decíduo com conseqüente migração mesial dos molares adjacentes. Comentaram que quando um dente se perde, o seu adjacente tende a migrar em direção ao espaço presente, e quando a perda ocorre unilateralmente, resulta numa assimetria dentária. Somente uma oclusão muito estável pode prevenir estas migrações secundárias. Descreveram um caso clínico em que foi realizada uma biomecânica com sistema assimétrico de força para a correção da linha média. A paciente de 24 anos apresentava uma relação de Classe II, subdivisão direita, uma sobressaliência de $11 \mathrm{~mm}$, uma sobremordida de $5 \mathrm{~mm}$ e um desvio de linha média dentária superior de $6 \mathrm{~mm}$ para a esquerda, além de um apinhamento nos incisivos inferiores. Pela análise cefalométrica, verificou-se um padrão braquicefálico, altura facial diminuída e um mau relacionamento entre as bases ósseas. Os incisivos superiores estavam suavemente vestibularizados e os inferiores lingualizados, apresentando interposição do lábio inferior. Como a paciente apresentava um odontoma envolvendo o incisivo lateral esquerdo, este elemento dentário foi perdido, colapsando o arco na região do canino inferior esquerdo. Como tratamento, utilizouse um arco segmentado para abertura de espaço para uma prótese adesiva na região do incisivo perdido, por meio de um sistema de forças assimétrico. Para tanto, forças de intrusão e inclinação nos incisivos inferiores foram utilizadas para correção da sobressaliência, finalizando-se o caso com as linhas médias dentárias coincidentes entre si. A paciente demonstrou grande satisfação com o resultado obtido com este planejamento.

Pesquisando sobre a técnica segmentada de intrusão simultânea com 0 fechamento de espaço, SHROFF et al. ${ }^{157}$, em 1995, comentaram que a correção da sobremordida profunda em pacientes com incisivos vestibularizados torna-se difícil com a mecânica ortodôntica convencional. Desta forma, propuseram-se a apresentar e discutir a biomecânica do aparelho com três segmentos de arco que permite a intrusão e a retração simultâneas dos dentes anteriores, bem como a correção de suas inclinações axiais. Mostraram também a seqüência de tratamento, o desenho do aparelho e o modo de contornar seus efeitos colaterais. Comentaram 
que o sistema de força aplicado no segmento anterior depende do ponto de aplicação da força intrusiva e de sua direção. A baixa taxa de deflexão deste aparelho expressa uma força constante, podendo-se manter o nível de força baixo. Concluíram que a técnica segmentada constitui-se num método vantajoso e preciso de controle dos movimentos dentários nos sentidos ântero-posterior e vertical, liberando um sistema de força estático com o mínimo de tempo gasto com o paciente.

Ainda neste ano, JANSON et al. ${ }^{75}$ discutiram as implicações da assimetria dentária no diagnóstico e plano de tratamento ortodôntico. Descreveram um caso clínico de má oclusão de Classe II, divisão 1, subdivisão com ligeiro apinhamento superior e inferior, desvio de linha média inferior para a direita e suave protrusão labial. A paciente foi tratada com extrações de dois pré-molares superiores e um pré-molar inferior, do lado da Classe I. Os resultados demonstraram que a correção de casos semelhantes com extrações assimétricas permitem a obtenção de uma relação de Classe I, de caninos, com ótimo relacionamento dos dentes anteriores e coincidência das linhas médias dentárias. Uma guia anterior imediata e um excelente perfil facial foram também obtidos, comprovando a eficiência desta opção de tratamento, nestes casos.

A mecânica de retração unilateral constitui-se num desafio, uma vez que causa inúmeros efeitos colaterais, durante o tratamento ortodôntico. SHROFF; LINDAUER; BURSTONE ${ }^{156}$, em 1997, comentaram sobre o diagnóstico diferencial e plano de tratamento das más oclusões de Classe II, subdivisão, baseando-se num tratamento biomecânico com momentos de inclinação. Preconizaram a correção da inclinação axial dos molares, utilizando a técnica do arco segmentado com momentos de retração unilateral no tratamento das assimetrias dentárias. Comentaram que esta técnica permite a aplicação de um sistema de forças diferenciado nos lados direito e esquerdo do arco, sem que ocorram efeitos indesejáveis, tais como: inclinação do plano oclusal, extrusão e mesialização das raízes dos molares e alterações no arco inferior decorrentes do uso de elásticos de Classe II. Utilizam a retração unilateral, principalmente, para corrigir a inclinação 
axial mesiodistal dos molares em casos de assimetrias dentárias e esqueléticas suaves, produzindo compensações dentárias.

Em 1998, WOHL; BAMONTE; PEARSON ${ }^{181}$, descreveram o caso de uma paciente de 13 anos e três meses com Classe II, divisão 1, subdivisão esquerda, apresentando as linhas médias dentárias coincidentes com o plano sagital mediano. O arco superior encontrava-se atrésico na região anterior, com ambos os incisivos laterais lingualizados. Pela análise cefalométrica, verificourse um padrão normodivergente da mandíbula em relação à base do crânio, o terço inferior da face ligeiramente diminuído, incisivos superiores protruídos e vestibularizados e incisivos inferiores bem posicionados no osso basal. O plano de tratamento permitiu 0 crescimento das bases ósseas, optando-se pela expansão do arco superior e uso da placa lábio-ativa no arco inferior. Posteriormente, realizoutse uma distalização assimétrica dos molares e retração dos caninos, para correção do trespasse horizontal de $7 \mathrm{~mm}$, com arco extrabucal assimétrico, apresentando maior força do lado esquerdo, além do uso dos elásticos de Classe II. Todo o tempo de tratamento levou 19 meses, obtendo-se uma relação de canino e de molar em Classe I. Concluíram que o sucesso e estabilidade destes casos se deve a uma ótima cooperação por parte da paciente.

O diagnóstico, o plano de tratamento ortodôntico e o tipo da mecânica assimétrica requerem diferenciação entre os problemas dentários e esqueléticos. Embora, muitas informações possam ser retiradas das análises cefalométricas, 0 exame clínico e os modelos de estudo oferecem importantes recursos para o estabelecimento do diagnóstico da discrepância esquelética. Inclinações axiais assimétricas e anormais podem produzir uma assimetria dentária, ou se a natureza compensar, pode mascarar um problema esquelético severo. O papel da inclinação axial no diagnóstico aplica-se às seguintes situações: casos de subdivisão, mordidas cruzadas unilaterais, discrepâncias de linha média, desvios da forma do arco e inclinações frontais do plano oclusal. A solução das inclinações axiais assimétricas depende do plano de tratamento. Os tratamentos sem extração requerem a manutenção das inclinações axiais assimétricas, compensatoriamente, entretanto, 
casos cirúrgicos e terapêuticas extracionistas devem ser realizados simetricamente ${ }^{25}$.

Pesquisando sobre o tratamento de pacientes com assimetrias, utilizando mecânica assimétrica, SHROFF; SIEGEL ${ }^{155}$, em 1998, consideraram que as correções ortodônticas das assimetrias dentárias geralmente constituem-se num processo complexo e desafiador. Um diagnóstico diferencial meticuloso, juntamente com um plano de tratamento preciso podem levar ao sucesso da correção destas más oclusões. Desta forma, descreveram que a rotação e a inclinação axial dos molares, a presença de mordida cruzada posterior e a perda prematura dos dentes decíduos, constituem-se elementos chaves do diagnóstico diferencial para a detecção das possíveis assimetrias. Comentaram que as más oclusões de Classes II, subdivisão podem ser corrigidas, conservadoramente, com elásticos de Classe II unilaterais, molas abertas superelásticas ou cursores, jasper jamper unilateral, aparelho removível de Shamy, expansor tipo pendulum, ancoragem extrabucal assimétrica e preparo de ancoragem, com dobras distais unilaterais.

Em 1999, TODD et al. ${ }^{168}$ descreveram um caso clínico de extração assimétrica da Classe II, divisão 1, subdivisão esquerda, acompanhado de uma mordida cruzada anterior e posterior. A paciente leucoderma apresentava 17 anos e três meses de idade, com assimetria dentária do arco inferior. Na análise facial, perceberam que a paciente apresentava um perfil facial reto e agradável, com proporções faciais verticais normais. A linha média dentária superior estava desviada um milímetro e a inferior, cinco milímetros, ambas para a esquerda, em relação ao plano sagital mediano. Pelo exame intrabucal e de modelos, a má oclusão do lado direito era de Classe I de molar e de canino, enquanto do lado esquerdo era Classe II de molar e de canino. Desta forma, o plano de tratamento implementado consistiu em extrações de dois primeiros pré-molares superiores e de um pré-molar inferior direito. A mecânica de edgewise empregada baseou-se na utilização de aparelhos fixos, com arcos ortodônticos para a expansão do arco superior e correção da mordida cruzada anterior e posterior, realizando-se simultaneamente o alinhamento e nivelamento dos arcos. O canino inferior direito foi 
retraído até a obtenção da simetria bilateral do arco inferior, com a correção das linhas médias superior e inferior. Utilizou-se de elásticos intermaxilares para a obtenção de uma melhor intercuspidação dentária, finalizando-se o caso com Classe I de molar e de canino do lado direito e Classe II de molar, no lado esquerdo, alcançando uma sobremordida e uma sobressaliência ideais e coincidência das linhas médias superior e inferior, além da eliminação da mordida cruzada.

\subsubsection{1 - Mecânicas assimétricas empregadas na correção da Classe II, subdivisão}

A ancoragem extrabucal unilateral também atua na correção da Classe II, subdivisão nos casos de pacientes em crescimento, em que o desvio ânteroposterior não seja tão acentuado ${ }^{73,155}$. Entretanto, HERSHEY; HOUGHTON; BURSTONE $^{64}$, em 1981, comentaram que apesar deste aparelho ser efetivo na produção da força de distalização unilateral, o braço interno do arco tende a criar uma mordida cruzada do lado onde se está recebendo a maior força. Além disso, este aparelho tem suas limitações, requerendo também uma colaboração por parte do paciente ${ }^{73,155}$.

Sobre as estratégias de tratamento com aparelhos removíveis, CETLIN; TEN HOEVE $^{29}$, em 1983, relataram que o aparelho de Shamy, para a correção unilateral da má oclusão de Classe II também apresenta vantagens e desvantagens. Similarmente aos elásticos de Classe II, os aparelhos removíveis dependem da cooperação por parte do paciente para se obter o sucesso ao final do tratamento. 0 aparelho de Shamy utiliza todo o arco dentário superior como ancoragem, possuindo uma mola de distalização unilateral que serve para corrigir a relação de Classe II, subdivisão. Afirmaram que um dos efeitos colaterais deste tratamento conservador implica na grande perda de ancoragem e conseqüente mesialização dos dentes ântero-superiores, podendo ser ou não um efeito desejável.

De acordo com GIANELLY; BEDNAR; DIETZ ${ }^{50}$, em 1991, a Classe II unilateral também pode ser corrigida com molas abertas ou cursores que distalizam 
o molar unilateralmente, corrigindo sua inclinação axial mesiodistal. Esta distalização do molar unilateral do arco superior torna-se mais aplicável antes da erupção dos segundos molares. As molas distribuem uma força distal para a coroa do molar, além de um momento distal e uma força mesial para os pré-molares e caninos, inclinando estes dentes para anterior. Para tanto, botões de Nance devem ser empregados para incrementar a ancoragem no arco superior, podendo ainda se utilizar elásticos de Classe II unilaterais, simultaneamente, visando contrabalancear a força mesial ocasionada pelas molas ${ }^{155}$. Novamente, como componente extrusivo dos elásticos de Classe II, surgem efeitos colaterais indesejáveis desta mecânica, como a descoordenação dos arcos e a abertura de diastemas nos incisivos inferiores $^{25,155}$. A utilização de cursores nos arcos contínuos servem para corrigir a inclinação axial mesiodistal dos molares, embora causem efeitos indesejáveis semelhantes aos elásticos de Classe $1 I^{155}$.

Em 1991, BLACKWOOD ${ }^{18}$ e COPE et al. $^{35}$, em 1994, comentaram que o aparelho tipo jasper jumper, quando ativado unilateralmente, tem sido empregado para a correção da Classe II, unilateral. Recomendaram que a utilização deste aparelho geralmente deve ser realizada com um fio redondo contínuo, no arco superior, e um fio retangular espesso, no arco inferior. O molar superior não somente sofre uma distalização, como também uma intrusão. Como resultado do ponto vestibular de aplicação da força intrusiva, o molar superior pode se inclinar vestibularmente, aumentando ainda mais a sobressaliência lateral. No arco inferior, a seção anterior do arco sofre uma força mesial e intrusiva. Isto promove uma inclinação do plano oclusal ântero-inferior, intruindo os dentes anteriores do lado em que há a correção da Classe II, abrindo diastemas nos incisivos inferiores. A falta de relacionamento entre os arcos ocorre devido à aplicação unilateral do sistema de forças, criando uma sobressaliência assimétrica e uma discrepância excessiva de linha média ${ }^{155}$. A utilização unilateral do jasper jumper pode ser vantajosa nestes situações clínicas, auxiliando na correção das linhas médias. O controle da posição dos incisivos inferiores e a ancoragem do arco inferior podem ser incrementadas pela inclusão dos segundos molares no arco retangular e pela incorporação de torque lingual de coroa nestes dentes ${ }^{155}$. 
Os casos mais simples em que o molar se apresenta rotado unilateralmente, pode-se recorrer aos arcos transpalatinos que produzem forças estáticas efetivas na correção de uma pequena rotação que ocasiona uma suave assimetria dentária. A colagem do aparelho fixo deve ser realizada, principalmente, no arco superior, pois os incisivos, caninos e pré-molares funcionam como ancoragem, controlando os efeitos indesejáveis do arco transpalatino. Quando se corrige a rotação do molar, ocorre uma melhora da oclusão deste lado do arco, entrando em chave de Classe I. No plano sagital, a inclinação axial do molar do lado oposto ao rotado mantem-se pela colocação de um segmento rígido de fio que funciona como ancoragem. No lado do molar rotado, um componente de força mesial pode ocorrer, entretanto a quantidade clinicamente visível de inclinação anterior dos dentes pode ser minimizada pela presença das unidades dentárias adjacentes. O expansor fixo tipo pendulum pode ser utilizado na correção das más oclusões suaves de Classe II, subdivisão. Este aparelho dentomucosuportado ancora-se no palato, apresentando molas de beta-titânio TMA desenvolvidas para distalizar os molares unilateralmente ou bilateralmente. Entretanto, apresenta o inconveniente de dificultar o controle da ancoragem na região anterior do $\operatorname{arco}^{155}$.

Para os casos suaves de Classe II, subdivisão, a utilização de elásticos de Classe II unilaterais causam efeitos indesejáveis que dependem da magnitude e do ponto de aplicação da força, bem como do tempo de duração da sua utilização ${ }^{25,155,156}$. Alterações significantes do plano oclusal maxilar anterior, resultantes do componente vertical dos elásticos de Classe II extruem o lado do arco onde o elástico está sendo utilizado. O plano oclusal do lado da correção sofre também uma inclinação acentuada em decorrência das forças verticais aplicadas nas porções ântero-superior e póstero-inferior, tornando a estabilidade do tratamento questionável, especialmente quando não ocorre um crescimento adequado. Uma descoordenação dos arcos pode se desenvolver, juntamente com uma abertura de diastemas nos incisivos inferiores ${ }^{25,155}$. Além disso, o aparecimento de uma sobressaliência assimétrica geralmente funciona como o primeiro sinal da ocorrência destes efeitos colaterais ${ }^{25,155,156}$. 
As discrepâncias menores de coordenação de linha média geralmente podem ser tratadas nos estágios finais, com elásticos de Classe II e Classe III, associados a um elástico diagonal anterior 2,73,89,131. Entretanto, se os arcos apresentarem formas assimétricas, talvez haja a necessidade de se utilizar elásticos intermaxilares cruzados nas regiões de caninos e pré-molares, com a forma do arco distorcida no sentido oposto ${ }^{158}$.

Nos casos de Classe II, subdivisão com sobremordida profunda, degraus distais unilaterais incorporados aos aparelhos fixos $4 \times 2$, ou mesmo, aos arcos contínuos, podem corrigir a inclinação unilateral do molar. Este sistema de força produz um momento distal no molar do lado em que foi realizado o degrau, promovendo, simultaneamente uma intrusão no segmento anterior do arco do mesmo lado. Isto ocasiona uma inclinação do plano oclusal anterior dificilmente corrigida $^{155}$.

A correção das inclinações axiais anormais dos molares pode ser realizada pelos momentos distais de forças unilaterais ${ }^{25,155}$. Como muitos casos de subdivisão apresentam-se associados a uma sobremordida profunda, pode-se corrigir 0 segmento anterior pelo movimento de intrusão e, simultaneamente, pela posição anterior destes molares, distalizando-os por meio de momentos de força ${ }^{155}$. Quando se deseja que forças de distalização assimétricas bilaterais sejam implementadas, pode-se recorrer à combinação de três segmentos de arcos-base $25,156,157$. As molas de distalização são acopladas bilateralmente nas extensões distais do segmento rígido anterior do arco conectado aos quatro dentes anteriores. Considera-se o ponto de aplicação de força no segmento anterior do fio, o centro de resistência dos dentes ântero-superiores, promovendo uma intrusão controlada na inclinação axial dos quatro incisivos, enquanto os molares sofrem distalização e extrusão bilateral e os pré-molares e caninos são encorajados a se movimentarem para distal, consecutivamente. À medida que os molares distalizam, os ganchos destas molas deslizam para trás da extensão do fio anterior, mudando o ponto anterior de aplicação de força, necessitando uma constante monitoração da posição destes ganchos, durante o tratamento. Em situações de inclinação axial do molar unilateral, 
pode-se combinar a técnica segmentada com a utilização dos arcos transpalatinos. Após a correção unilateral da inclinação axial do molar, estando a oclusão dos lados direito e esquerdo simétricas, o tratamento ortodôntico pode prosseguir com a mecânica simétrica nos quatro quadrantes ${ }^{155}$.

\subsubsection{2 - Correção das discrepâncias de linha média}

O alcance da coincidência das linhas médias dentárias superior e inferior consiste num objetivo a ser estabelecido no tratamento ortodôntico para que haja uma intercuspidação satisfatória e uma harmonia dentária ${ }^{49}$. Considera-se a disposição simétrica dos dentes um componente importante de um sorriso atraente $^{67,77,152}$, enquanto a assimetria compromete a estética dentária ${ }^{15}$. Por esta razão, a posição das linhas médias deve receber total atenção durante a terapia ortodôntica.

Os desvios da linha média constituem-se num dos problemas mais comuns e persistentes que os ortodontistas se deparam. Podem ser verificados em todos os tipos de casos, porém parecem ser vistos mais freqüentemente nas más oclusões de Classe II. A coordenação das linhas médias assume grande importância no plano de tratamento ortodôntico e a complexidade de sua correção aumenta de acordo com a duração da terapia ${ }^{89}$. As discrepâncias de linha média significantes geralmente se relacionam com a perda de ancoragem, entretanto, algumas vezes, podem ser corrigidas durante a última fase do tratamento ortodôntico. Embora os elásticos assimétricos intermaxilares sejam o recurso mais utilizado para resolver este problema, o vetor de força vertical e a possibilidade de má colaboração por parte do paciente podem produzir efeitos indesejáveis com a terapia fixa ${ }^{24}$.

Desde os primórdios da Ortodontia, há quase um século, ANGLE ${ }^{4}$, em 1907, utilizou o elástico de Classe III e o elástico diagonal anterior ambos associados a uma expansão do arco dentário, para a correção das discrepâncias de linha média. 
Anos mais tarde, STRANG; THOMPSON ${ }^{163}$, em 1958, recomendaram uma biomecânica para correção dos desvios de linha média que consistia numa alça vertical na mesial de cada canino, num arco de fio redondo de calibre 0.020 polegadas que movimentava, em bloco, os quatro incisivos em direção ao lado da correção do desvio de linha média. Este arco era segmentado em três partes, sendo uma anterior e duas posteriores, tendo um potencial de ativação limitado dentro das canaletas dos acessórios de 0.022 polegadas. Determinaram que os dentes anteriores deveriam ser individualmente amarrados na seção anterior do arco, enquanto os dentes posteriores deveriam ser conjugados como se fosse uma só unidade. As alças deveriam ser confeccionadas bem próximo à mesial dos caninos. Quando se adicionava helicóides a estas alças, havia uma maior flexibilidade e ativação, ocorrendo uma rápida correção da linha média, sem a necessidade da soldagem dos ganchos de retração. Geralmente, em apenas duas consultas, a correção era obtida, sendo o arco anterior removido e os segmentos posteriores permaneceriam amarrados para, posteriormente, mesializarem de acordo com a técnica individual do profissional.

BREAKSPEAR ${ }^{22}$, em 1963, comentou que a maioria dos casos que termina muito aquém de um resultado ideal decorrem de discrepâncias laterais entre as linhas médias dentárias superior e inferior. Nestes casos, deve-se realizar um ajuste oclusal que pode ou não corrigir a assimetria dentária ou facial. Portanto, sempre se deve priorizar a finalização dos casos com a coincidência das linhas médias do que se deparar com este problema após ter finalizado a terapia ativa.

Em 1967, BUCHIN²3 afirmou que as discrepâncias de linha média são fáceis de serem corrigidas e não constituem um grande problema. A correção torna-se difícil de ser mantida quando a discrepância for causada por uma assimetria esquelética. Quando em presença de desvios de linha média decorrentes de assimetrias dentárias a linha média inferior geralmente se encontra desviada para o lado da relação de Classe II. No tratamento da má oclusão de Classe II, divisão 1 subdivisão, utiliza-se um elástico de Classe II de um lado, um de Classe III do outro e um elástico cruzado anterior. Desta forma, com o nivelamento e remoção das 
interferências cuspídicas, a má oclusão passa a ser uma 1/2 Classe II, divisão 1 bilateral. A correção completa do caso, até a obtenção da chave de canino em Classe I, com a utilização dos elásticos intermaxilares pode ser obtida em 8 a 10 semanas, com ligeira sobrecorreção. Todos os elásticos devem se dispor paralelamente um ao outro, sendo o anterior o mais importante. Quando ocorre iatrogenia durante a mecânica ou rotação mandibular, a correção também se procede da mesma maneira.

Em 1970, GIANELLY; PAUL $^{49}$ divulgaram que durante 0 tratamento ortodôntico, os dentes devem ser posicionados em busca de uma harmonia dentoesquelética. As posições finais dos dentes devem assumir uma relação oclusal de Classe I, com um perfeito alinhamento, contato proximal, inclinações axiais adequadas e intercuspidação máxima. Assim como os dentes superiores e inferiores devem apresentar um perfeito relacionamento, as linhas médias superior e inferior devem estar coincidentes, havendo uma quantidade semelhante de material dentário em cada hemiarco. Comentaram que se as linhas médias não estão coincidentes, a intercuspidação máxima torna-se improvável, porque a posição das cúspides no lado em que está o desvio da linha média localiza-se mais posteriormente, enquanto que a do lado oposto, as cúspides situam-se mais anteriormente. Afirmaram que nos casos em que o arco superior apresenta coincidência de linha média dentária e o inferior apresenta desvio, ambos em relação ao plano sagital mediano; deve-se utilizar o arco superior como unidade de ancoragem, estabilizando-o com um arco retangular passivo para a correção do desvio de linha média dentária inferior. Concluíram que a utilização do sistema de elásticos de Classe II e III, propostos por BUCHIN ${ }^{23}$ corrige a discrepância de linha média em, no máximo, dois meses. Enfatizaram a necessidade do controle da inclinação das raízes para complementação dos casos, além da incorporação de dobras de segunda ordem nos caninos e nos molares.

Investigando sobre a influência das alterações do plano oclusal na oclusão dentária durante o tratamento ortodôntico, SIMONS; JOONDEPH ${ }^{150}$, em 1973, relataram que o plano oclusal sofre uma rotação para baixo e para trás, tornando 
uma Classe II dentária numa relação de Classe I, quando se utiliza elásticos de Classe II. De modo contrário, JACOBSON et al. ${ }^{72}$, em 1974, comentaram que quando o plano oclusal sofre uma rotação para cima e para frente, uma Classe III dentária tende a se tornar uma Classe I, quando na presença de elásticos de Classe III. O plano oclusal pode ser alterado pela utilização de forças extrabucais e mecânicas que se baseiam no preparo de ancoragem.

Anos mais tarde, LEWIS $^{89}$, em 1976, relatou que poucos trabalhos foram publicados a respeito das possíveis causas destas discrepâncias e como elas influenciam a má oclusão. Apresentou uma lista de fatores responsáveis pelo desvio da linha média: 1) mordida cruzada posterior associada ao desvio mandibular; 2) inclinação e/ou migração dos dentes anteriores superiores e/ou inferiores; 3) desvio lateral mandibular, sem mordida cruzada (rotação mandibular resultante de interferências oclusais); 4) arcos assimétricos; 5) discrepâncias de tamanho dentário e a combinação dos quatro primeiros itens. Desta forma, a assimetria, as discrepâncias de linha mediana e os desvios mandibulares jamais se autocorrigem, devendo ser analisados cuidadosamente e tratados, para a obtenção da estética e estabilidade dos casos. Argumentou que a correção de um desvio de linha média, causado pelo suave desvio da mandíbula, nos casos em que não há mordida cruzada, geralmente torna-se mais fácil nos estágios finais do tratamento. Deste modo, recorre-se à utilização simultânea de elásticos de Classe II, tracionando este lado anteriormente e elástico diagonal anterior, corrigindo a posição mandibular e dentária para o centro da face. Quando a mordida cruzada posterior está presente, indica-se primeiramente o seu descruzamento, corrigindo posteriormente a linha média desviada. Isto ocorre visto que o desvio indica que a oclusão não está bilateralmente correta. Nos casos de perda precoce de dentes decíduos ocorre migração dos dentes adjacentes para o espaço, ocasionando desvio da linha média em um ou ambos os arcos dentários. LEWIS $^{89}$ ainda recomenda a utilização de mecânica com molas de distalização em vez de dobras de segunda ordem, associadas a cursores e elásticos de Classe II, para distalizar os dentes pósterosuperiores em casos de arcos assimétricos. Comentou ainda que os dentes 
superiores, do lado de Classe II, devem ser distalizados um a um até que haja a coincidência das linhas médias.

Em relação ao equilíbrio dos elásticos de retração, BEGG; KESLING ${ }^{10}$, em 1977, comentaram que estes elásticos associados a uma tração de Classe II adequada, durante o estágio 2, mantêm as linhas médias coordenadas entre si. Afirmaram também que há a possibilidade de aumentar a ação dos elásticos de Classe II unilaterais, do diagonal anterior e de Classe III com molas de verticalização que promovem a movimentação dos dentes, efetuando mudanças na linha média.

Investigando sobre as implicações estéticas das más oclusões na aparência dentofacial, SHAW et al. ${ }^{152}$, em 1985, determinaram se a atratividade de jovens adultos seria modificada pela sua aparência estética. Utilizaram cinco diferentes disposições fotográficas, em preto e branco, de dois homens e duas mulheres, modificando-as de modo que, em cada versão a face era padronizada, excetuando o problema estético dentário. Os cinco tipos de face de cada paciente diagramadas artificialmente apresentaram os seguintes problemas: incisivos bem posicionados, incisivos proeminentes, incisivo lateral superior ausente, incisivos excessivamente apinhados e fenda labial unilateral. Oitocentos adultos foram convocados para julgar estas 20 faces, utilizando escores para estimar a característica individual social de cada face. Concluíram que as faces que apresentavam os incisivos alinhados e nivelados apresentaram mais atratividade, socialização, popularidade e sinônimo de inteligência. As faces com os incisivos proeminentes receberam conceitos de fidelidade e honestidade, enquanto que as faces com fissura unilateral receberam os menores pontos de estética facial. Desta forma, afirmaram que os pacientes que apresentavam dentes bem posicionados eram mais atraentes socialmente.

As discrepâncias significantes de linha média geralmente decorrem da perda de ancoragem, devendo ser corrigidas, na maioria das vezes, nas últimas fases do tratamento ortodôntico. Embora os elásticos intermaxilares assimétricos sejam o meio mais popular de se resolver este problema, os vetores de forças verticais e a possibilidade de falta de cooperação podem criar efeitos colaterais indesejáveis, com 
a mecânica dos aparelhos fixos. Em 1986, PROFFIT ${ }^{131}$ assegurou que as discrepâncias menores de coordenação de linha média podem ser tratadas nos estágios finais com elásticos assimétricos de Classe II e de Classe III, evitando-se ao máximo os elásticos unilaterais. Os elásticos intermaxilares de Classe II ou de Classe III associados a um elástico diagonal anterior podem ser necessários para a finalização ideal dos casos e comentou que a correção de discrepâncias acentuadas torna-se complexa, após o fechamento dos espaços de extração.

A utilização de elástico diagonal anterior associado aos elásticos de Classe II ou III foi recomendada por ALEXANDER ${ }^{2}$, em 1987, em más oclusões de Classe II ou III, respectivamente. Realiza-se este procedimento, na maioria dos casos, durante os estágios de finalização. Com exceção dos planejamentos com extração em que se deve utilizar durante o fechamento dos espaços, juntamente com o elástico diagonal anterior, quando uma discrepância significante de linha média estiver presente.

A coordenação das linhas médias e a simetria facial constituem a base para uma face harmoniosa e agradável. Em 1990, JERROLD; LOWENSTEIN ${ }^{77}$ salientaram que as três linhas médias do paciente: a facial, a maxilar e a mandibular devem ser avaliadas para o diagnóstico e o tratamento adequados dos casos. A máxima intercuspidação, a função e a estabilidade dos resultados, as estéticas facial e dentária anterior e a diminuição da potencialidade das disfunções temporomandibulares constituem-se as metas propostas para se obter o sucesso dos casos. O diagnóstico diferencial apropriado da discrepância permite que o profissional utilize mecânicas inter e intramaxilares para a resolução dos desvios da linha média. A correção da linha média deve começar desde o início do tratamento e após sua coordenação, devem ser mantidas como referencial para qualquer sistema de força utilizado na finalização dos casos. Quando a discrepância de linha média é suave entre um a dois milímetros, pode-se inclinar os dentes anteriores numa posição que coincida com a linha média facial. Se a linha média inferior se encontra desviada para o lado oposto, deve-se corrigí-la por inclinação. As molas de verticalização, juntamente com elásticos diagonais anteriores podem ser adaptadas 
para se obter uma coincidência das linhas médias, com a simetria dos incisivos em relação ao plano sagital mediano. A estética resultante deste procedimento é geralmente desfavorável, embora dependa da posição dos lábios do paciente, da linha do sorriso e da quantidade de dentes que foram inclinados. A retração acentuada dos caninos constitui-se numa causa do desvio de linha média, ocorrendo quando o profissional não fica atento à obtenção da coincidência das três linhas médias do paciente. Concluíram que a maioria das formas de tratamento parece associar a discrepância de linha média como sendo resultante de um desvio ou qualquer rotação mandibular. Entretanto, quando o desvio de linha média resulta de uma migração dentária, em uma face simétrica, o emprego dessas mecânicas pode alterar a posição mandibular, obtendo-se linhas médias dentárias coincidentes, porém uma face assimétrica.

Em relação à coordenação das linhas médias em arcos assimétricos, SINCLAIR ${ }^{158}$, em 1993, realizou um pesquisa clínica objetivando avaliar se normalmente os ortodontistas realizavam alguma modificação da forma dos arcos pré-fabricados nos casos assimétricos. Verificou que $73 \%$ dos profissionais consideraram ser necessário modificar as formas dos arcos nos casos de assimetria, enquanto que outros $27 \%$ negaram esta afirmação. Noventa e três por cento deles afirmaram, ainda, que coordenavam os arcos. Algumas respostas relataram que certos casos assimétricos requerem a correção das formas distorcidas dos arcos pela utilização de elásticos intermaxilares cruzados nas regiões de caninos e prémolares, com os arcos distorcidos na direção oposta.

Pesquisando sobre o tratamento do desvio de linha média em uma paciente adulta, SCHUDY ${ }^{46}$, em 1996, afirmou que a largura dos arcos superior e inferior determina a posição funcional mandibular. Se o arco mandibular é mais largo que o arco maxilar, o paciente oclue em habitual em um ou outro lado, podendo desenvolver uma mordida cruzada. Da mesma maneira ocorre com o arco maxilar. Quando os dentes posteriores ocluem cúspide-cúspide em vez de cúspide-fossa, até pequenos movimentos habituais da mandíbula para um lado ou outro podem induzir uma mordida cruzada. Desta forma, apresentou um caso de uma paciente com 42 
anos de idade, com má oclusão de Classe II, subdivisão, desvio da linha média inferior, discrepância do arco inferior, sobremordida profunda e sobressaliência severa. A má oclusão foi corrigida enquanto o côndilo direito foi deliberadamente movimentado para anterior com elásticos utilizados diariamente, durante dez meses. Após dez anos de tratamento, verificourse uma estabilidade do caso, apresentando uma Classe I de molar, com discrepância corrigida, além da correção da sobressaliência e da sobremordida acentuadas. O tecido periodontal apresentourse saudável e ambas as ATMs apresentaram espaços articulares adequados, suave contorno das superfícies ósseas e ausência de sintomatologia dolorosa. A estética e a função da má oclusão corrigida mostraram-se satisfatórias tanto para o paciente como para o autor.

A função, o relacionamento espacial maxilomandibular, a oclusão dentária e a estética facial são influenciados pela inclinação ou angulação do plano oclusal. BRAUN; LEGAN²1, em 1997, investigaram as alterações do plano oclusal com a utilização dos elásticos intermaxilares na oclusão dentária, durante o tratamento ortodôntico. Definiram o relacionamento geométrico e matemático entre a oclusão dentária e as rotações do plano oclusal, numa visão sagital. Como guia clínico geral, estabeleceram que cada grau de rotação do plano oclusal resultaria em uma alteração de meio milímetro no relacionamento oclusal dentário. Consideraram este aspecto de suma importância visto que as alterações de inclinação do plano oclusal podem ser ora intencionais, ora não intencionais, durante a terapia ortodôntica. Verificaram que o plano oclusal de Downs rota, naturalmente, para cima e para frente, aproximadamente seis graus, durante o crescimento e o desenvolvimento craniofacial. Este fenômeno tende a desenvolver uma relação dentária de Classe II com três milímetros de discrepância ântero-posterior, apresentando implicações no desenvolvimento da dentição. Além disso, verificaram que há três principais fatores que parecem determinar o relacionamento dentário oclusal: 1) o potencial diferencial de crescimento esquelético maxilomandibular expresso pelo plano oclusal; 2) a mudança inerente na inclinação do plano oclusal durante o crescimento e desenvolvimento e 3) o espaço disponível de Nance. Comentaram que deve haver um equilíbrio destes fatores para que o desenvolvimento da dentição atinja uma 
relação de Classe I. Finalmente, concluíram que quando o plano oclusal sofre uma rotação para baixo e para trás, uma Classe II dentária tende a se transformar em uma Classe I, numa mecânica que utiliza elásticos de Classe II. De modo contrário, quando o plano oclusal sofre rotação para cima e para frente, uma Classe III dentária tende a se tornar uma Classe I, quando se utiliza elásticos de Classe III. O plano oclusal pode ser alterado pela utilização de forças extrabucais e mecânicas que se baseiam no preparo de ancoragem.

Avaliando a correção das discrepâncias de linha média por meio da terapia combinada ortopédica-ortodôntica, ERDOGAN; ERDOGAN ${ }^{41}$, em 1998, descreveram dois casos clínicos que mostravam assimetria facial moderada, desvio mandibular para um dos lados, perfil mole e sorriso normais. Em ambos os casos, uma Classe II subdivisão estava presente, sendo necessária uma mecânica assimétrica para o tratamento. Afirmaram que os elásticos intermaxilares assimétricos podem corrigir a linha média até $3 \mathrm{~mm}$, porém forças extrusivas verticais dos elásticos de Classe III e diagonal anterior excedem o vetor de força do elástico de Classe II, do lado oposto. Portanto, o plano oclusal maxilar pode ficar mais baixo do lado da Classe II, causando dificuldades na mecânica com aparelhos fixos. Desta forma, utilizaram o jasper jumper assimetricamente, com a mecânica convencional de Classe II de um lado, e do outro, uma mecânica de Classe III, para corrigir a discrepância de linha média e um possível desvio mandibular, resultante de uma deficiência maxilar. Descreveram os efeitos dentoesqueléticos deste tipo de tratamento em um caso, na fase inicial da dentadura permanente, e outro, num paciente adulto. Os efeitos dentários deste sistema de força são recíprocos, ou seja, os incisivos movimentam-se de corpo em direções opostas, enquanto a direção e a quantidade do movimento são controlados pelo tamanho dos jumpers. Concluíram que em ambos os casos houve a correção das assimetrias dos arcos dentários e a estabilidade dos resultados. Os aparelhos foram bem aceitos pelos pacientes e nenhum índice de quebra foi registrado, mesmo tendo sido acoplados mesialmente aos tubos dos molares. Além de que houve menor manifestação de efeitos adversos em comparação com o uso dos elásticos intermaxilares. 
A avaliação da estética facial consiste num componente importante do plano de tratamento ortodôntico, enquanto a simetria consiste num dos mais relevantes fatores na definição de um sorriso atraente ${ }^{67}$. Considera-se a posição da linha média dentária superior como um dos mais importantes aspectos de diagnóstico no plano de tratamento ortodôntico. Dependendo do paciente, entretanto, a obtenção da coincidência das linhas médias dentárias com a linha média facial torna-se difícil de ser obtida. Ainda mais, a avaliação da posição da linha média dentária pode se tornar complexa, quando outras linhas médias faciais não estão alinhadas. Assim, BEYER; LINDAUER ${ }^{14}$, em 1998, propuseram-se a estudar duas implicações: 1 verificar até quanto a linha média dentária superior pode se desviar da linha média facial e ainda ser considerada esteticamente aceitável e 2 - determinar como as posições dos vários pontos faciais medianos afetam a estética facial, de um modo geral. Cento e vinte examinadores, incluindo 30 ortodontistas, 30 clínicos gerais e 30 pais de pacientes, avaliaram as imagens digitalmente alteradas de dois casos, para determinar a aceitabilidade dos desvios de linha média dentária e priorizar a importância da localização de várias estruturas da linha média facial. Tolerourse uma média de 2,2 \pm 1,5mm de desvio da linha média dentária aceitável. Houve uma diferença significante $(p<0,05)$ na aceitabilidade do desvio entre os dois casos. Os ortodontistas foram considerados mais críticos em relação à aceitabilidade do desvio da linha média do que os clínicos gerais e os pais. Quando os desvios das várias estruturas das linhas médias foram avaliados, fotografias apresentando desvios das linhas médias superior e/ou desvios nasais foram consideradas menos estéticas. Concluíram que as diferenças encontradas neste estudo mostraram grandes graus de aceitabilidade de desvio da linha média entre os pacientes. Além disso, o mesmo desvio de dois ou três milímetros pode ser considerado aceitável em uma pessoa e inaceitável em outra, dependendo da sua relação com outros pontos faciais.

Para se estudar a assimetria esquelética cuidadosamente, torna-se necessário fazer um traçado no cefalograma póstero-anterior, visando a identificação das linhas médias superior e inferior. Para tanto, pontos específicos são identificados aproximadamente no centro das raízes dos incisivos superiores e inferiores. Estes pontos no terço médio das raízes denominam-se pontos da base 
apical. Linhas perpendiculares ao plano oclusal são traçadas destes pontos para se avaliar a existência de discrepâncias das linhas médias das bases apicais, sendo estas discrepâncias relacionadas com alguns tipos de assimetrias esqueléticas maxilares e, principalmente, mandibulares. Casos de discrepâncias das bases apicais dificultam o tratamento, pois exigem movimentação dentária em ambos os arcos, ocasionando perda de ancoragem e efeitos indesejáveis, como a inclinação e rotação dos arcos. Pelo exame clínico ou pela análise dos modelos de estudo, as inclinações axiais dentárias podem ser utilizadas na determinação da presença de discrepâncias das bases apicais. Pode-se mentalizar a verticalização dos dentes, fazendo com que as inclinações axiais para os lados direito e esquerdo se igualem, ou mesmo, visualizar onde os centros das raízes podem estar localizados, traçandose uma linha perpendicular imaginária ao plano oclusal. Se uma discrepância da linha média superior e inferior está presente, sem a presença de discrepância apical, o tratamento torna-se simplificado, pois forças simples podem ser utilizadas para inclinar os dentes, corrigindo as linhas médias correspondentes, não produzindo efeitos colaterais quando aplicadas adequadamente. De modo contrário, quando há uma discrepância verdadeira da base apical, a mecânica torna-se mais complexa, ocorrendo uma movimentação dentária mesiodistal mais restrita ${ }^{25}$.

Vários trabalhos ${ }^{14,21,67,78,152}$ verificaram como o impacto da estética dentária pode influenciar na atratividade facial, como um todo. JOHNSTON; BURDEN; STEVENSON ${ }^{78}$, em 1999, investigaram a percepção das discrepâncias entre as linhas médias dentária e facial, por meio de uma análise visual realizada por 20 ortodontistas e 20 leigos jovens. Utilizaram uma imagem fotográfica do sorriso de uma jovem, com a mesma expressão facial, modificando-se a linha média dentária em relação à linha média facial. Assim, pôde-se julgar o grau de atratividade do sorriso desta imagem, utilizando-se notas com escala de escores de dez pontos. Como resultados, verificaram que as imagens menos atraentes tanto para os ortodontistas como para os leigos relacionaram-se com o aumento da discrepância entre as linhas médias dentária e a facial. Os escores não avaliaram se a direção do desvio da linha média era para o lado direito ou esquerdo, e nem mesmo, referiurse ao gênero do examinador. Concluíram que os ortodontistas eram mais sensíveis 
que as pessoas comuns no que concerne às discrepâncias menores entre as linhas médias dentária e facial. Além disso, calcularam que a probabilidade dos leigos considerarem um menor escore de atratividade era de $56 \%$, enquanto que para os ortodontistas era de $83 \%$, quando havia uma diferença de $2 \mathrm{~mm}$ entre as linhas médias dentária e a facial. Denotoutse que mesmo nos casos de discrepância mínima, havia um efeito negativo na estética dentofacial. Assim, afirmaram que todo tratamento ortodôntico deve incluir a correção completa das discrepâncias das linhas médias dentárias superior e inferior, tolerando-se para os casos mais severos, até no máximo $2 \mathrm{~mm}$ de discrepância entre estas linhas.

\subsection{3 - Tratamento combinado ortodôntico-cirúrgico da Classe II, subdivisão}

A assimetria facial ocorre freqüentemente e quando se apresenta de forma severa deve ser tratada por meio de uma intervenção cirúrgica-ortodôntica. As diversas etiologias da assimetria facial podem ser decorrentes de problemas congênitos, de desenvolvimento, de causas patológicas ou injúrias. Para o sucesso da correção da assimetria facial, deve-se fazer um exame, um diagnóstico e um plano de tratamento sistemáticos ${ }^{85}$.

Nos casos em que o crescimento já se exauriu, deformidades esqueléticas podem ser corrigidas pelo tratamento ortodôntico cirúrgico ou ortodontia compensatória $^{131}$. A depender do caso cirúrgico, diferentes cirurgias podem ser realizadas. O enxerto ósseo e o implante de silicone ${ }^{185}$ aplicam-se aos casos decorrentes da falta de desenvolvimento do ramo ascendente, enquanto a condilectomia pode ser implementada nos casos de hiperplasia condilar. As técnicas de Obwegeser II, de um lado e Obwegeser-Dal Pont, do outro, preconizadas por MIZUNO ${ }^{108}$ (1988), podem ser executadas nos casos de assimetrias mandibulares. As osteotomias Le Fort I e em L invertido ${ }^{185}$, aplicam-se aos casos de assimetria maxilar e mandibular, respectivamente. Já nos casos de mandíbula apresentando pequena assimetria, realiza -se apenas uma genioplastia. 
AZAZ; NITZAN; BRIN ${ }^{6}$, em 1991, comentaram que o tratamento de escolha para os casos de hiperplasia condilar em estágio ativo deve ser a condilectomia com a correção cirúrgica simultânea ou posterior da assimetria facial. O processo de remodelação espontânea das estruturas faciais após a eliminação do côndilo hiperplásico em crescimento ativo pode melhorar a simetria, sem a necessidade de intervenções futuras. Desta forma, os autores descreveram dois casos em que as condilectomias foram realizadas após a confirmação do diagnóstico por meio da cintigrafia. Após a cirurgia, observou-se uma melhora da simetria facial, bem como a correção do desvio do mento e dos dentes. A radiografia panorâmica revelou côndilos normais, enquanto a telerradiografia lateral expressou um perfil ortognático, na visão sagital. Concluíram que quando se planeja a condilectomia em pacientes com hiperplasia condilar, a correção simultânea da assimetria facial e da má oclusão devem ser levadas em consideração. A correção cirúrgica deve ser adiada a depender do grau da severidade da assimetria, além da própria opinião pessoal do paciente quanto à sua aparência facial.

Em um estudo retrospectivo com 28 pacientes, SEVERT; PROFFIT ${ }^{149}$, em 1997, utilizaram as radiografias póstero-anteriores para se determinar as alterações e a estabilidade pós-cirúrgica da correção da assimetria facial severa. Todos os pacientes apresentavam osteotomia do ramo mandibular; sendo que 18 adultos também exibiam uma osteotomia Le Fort I, e oito apresentavam osteotomia da borda inferior da mandíbula. Foram determinadas as alterações nas posições verticais e transversais em cefalogramas póstero-anteriores de 14 pontos nos períodos précirúrgico, pós-cirúrgico imediato e após um ano de controle. Devido ao desvio mandibular para a esquerda, na grande maioria dos pacientes, as alterações durante a cirurgia constituíram inicialmente no recolocação do mento para a direita e no nivelamento do plano oclusal. A cirurgia maxilar para nivelar a inclinação do plano oclusal foi bastante estável, assim como a nova posição transversal do mento por meio da osteotomia da borda inferior. A cirurgia do ramo para reposicionar transversalmente o mento foi menos estável, com uma recidiva média de aproximadamente $1 / 3$ do movimento cirúrgico. Um terço dos pacientes apresentaram mais de $4 \mathrm{~mm}$ de alteração pós-cirúrgica na posição transversal do 
mento. Também foram observadas alterações pós-cirúrgicas significantes nos ângulos goníacos, provavelmente relacionadas à remodelação óssea nesta área. $\mathrm{A}$ cirurgia dupla da mandíbula foi tão estável, ou talvez levemente mais estável do que a cirurgia mandibular simples. Visto que estes pacientes apresentaram problemas mais severos e alterações cirúrgicas mais extensas do que os pacientes com assimetria típica, provavelmente os resultados não se aplicam aos casos de assimetria mais moderada.

YAMASHIRO; OKADA; TAKADA ${ }^{185}$, em 1998, descreveram o tratamento cirúrgico de dois casos clínicos que exibiam assimetria dentofacial, incluindo desvio mandibular e inclinação da maxila. Suas histórias médicas iniciais relataram a ocorrência de fratura condilar em período pubescente. No primeiro caso, a paciente sofreu uma fratura condilar esquerda aos seis anos de idade, sendo controlada durante três anos. Aos 25 anos, com o crescimento cessado, procurou tratamento ortodôntico, pois apresentava dificuldade em realizar o movimento de abertura bucal, sendo submetida a um implante de silicone na região condilar. Para a correção da assimetria facial severa, do retrognatismo mandibular, do apinhamento superior e inferior, do desvio esquerdo do mento de sete milímetros e dos movimentos bordejantes mandibulares limitados, recorreurse a terapia combinada ortodônticacirúrgica para eliminar o problema dentário e amenizar o esquelético. O segundo caso apresentava uma suave assimetria facial e mandibular, mordida aberta anterior e apinhamento dentário em ambos os arcos, além de um desvio do mento de dois milímetros para o lado esquerdo. Como esta paciente apresentava 12 anos na consulta inicial, tendo história de fratura condilar aos nove anos, planejaram um tratamento ortopédico até o final do crescimento, posteriormente, os primeiros prémolares superiores e inferiores foram extraídos, durante o tratamento ortodôntico pré-cirúrgico. Mais tarde, um reposicionamento cirúrgico maxilomandibular foi implementado para a finalização do tratamento com a ortodontia pós-operatória. Em ambos os casos, houve uma melhora da assimetria e do perfil facial, além da correção dos arcos dentários. 
Neste mesmo ano, LEGAN comentou que a hiperplasia condilar, em seu estágio inicial, apresenta uma mordida aberta no lado afetado, pois a erupção dentária não acompanha o crescimento mandibular. Nos casos mais severos, os dentes geralmente ocluem bilateralmente, mas o plano oclusal frontal encontra-se inclinado e muitas regiões da maxila, da mandíbula e do mento apresentam assimetria. O tratamento destes casos consiste em uma osteotomia segmentada Le Fort I para diferenciar a impacção da maxila dos lados direito e esquerdo, além da expansão do arco. Comentou que a osteotomia bilateral do ramo e a condilectomia devem ser realizadas para rotacionar a mandíbula do lado hiperplásico e uma genioplastia deve ser implementada para a correção da posição do queixo. 0 diagnóstico e o tratamento precoce da hiperplasia condilar previne muitas deformidades secundárias, como a inclinação do plano oclusal frontal maxilar. Em pacientes adultos, a cirurgia intracapsular no côndilo mandibular geralmente não se torna necessária, mas as osteotomias maxilar e mandibular não são requeridas. A osteotomia Le Fort I para o reposicionamento superior do lado afetado e as osteotomias bilaterais do ramo mandibular corrigem a angulação do plano oclusal, além de servirem, simultaneamente para a correção das discrepâncias ânteroposterior, vertical e transversal associadas. A genioplastia para correção da assimetria do mento, a osteotomia da borda inferior da mandíbula para a correção do lado afetado e/ou o aumento do bordo inferior do lado contralateral devem ser indicadas. Muitos casos ortodôntico-cirúrgicos assimétricos constituem variações de outras deformidades hipoplásicas ou hiperplásicas da mandíbula, devendo ser tratados pelo movimento assimétrico do segmento distal mandibular, utilizando osteotomias bilaterais do ramo. Os dois procedimentos cirúrgicos mais freqüentes compõem-se do corte sagital do ramo mandibular e osteotomia do ramo vertical intrabucal. Às vezes, o paciente com o côndilo hiperplásico beneficia-se da condilectomia para corrigir a assimetria mandibular e, freqüentemente, a forma e a posição maxilar devem ser corrigidas, necessitando de osteotomias maxilar e mandibular. A genioplastia, a mandibuloplastia, o aumento ou a redução do tecido mole e do bordo inferior mandibular contribuem adicionalmente na correção das assimetrias. A terapia ortodôntica direciona idealmente os dentes no osso basal. O planejamento ortodôntico e o controle biomecânico como o alinhamento, o 
nivelamento, o fechamento do espaço, o controle da largura do arco, o torque e a inclinação devem ser monitorados como objetivos cirúrgicos. Indica-se a biomecânica do arco segmentado, particularmente, quando o planejamento cirúrgico necessita de osteotomia, bem como da precisão no nivelamento pela intrusão, retração com ancoragem máxima, torque segmentado e quando a inclinação e/ou controle das dimensões transversais tornam-se requeridas.

Pelo que foi demonstrado, existem diversos trabalhos que analisaram as alterações do tratamento da Classe II, bilateral, em radiografias cefalométricas laterais. Entretanto, há uma grande escassez de trabalhos que estudaram as alterações da correção da Classe II, subdivisão, especialmente nos planos horizontal e frontal. Portanto, com a finalidade de investigar as alterações do tratamento, com as extrações assimétricas, deste tipo específico de má oclusão nestes planos, desenvolveu-se este trabalho. 


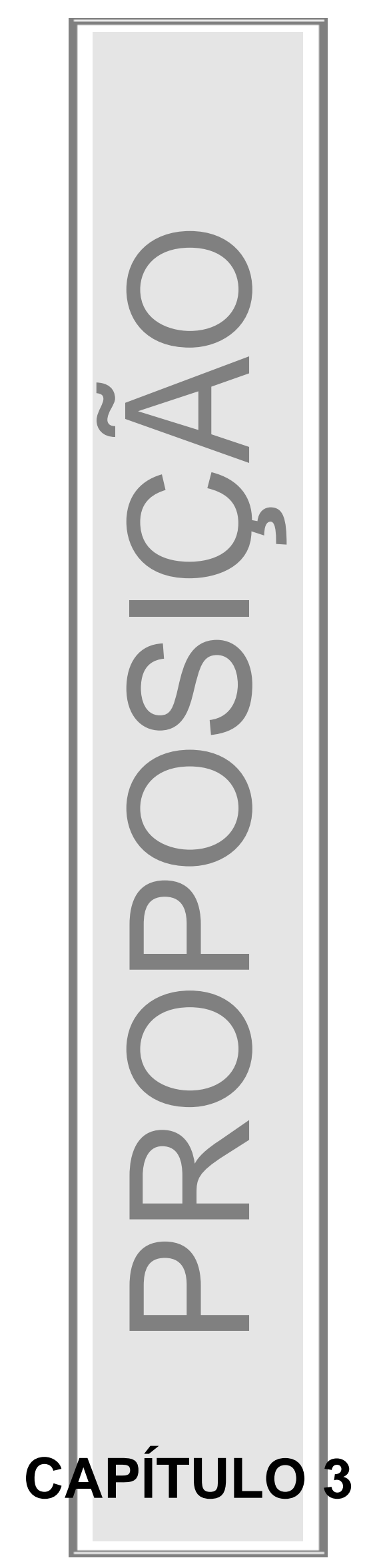




\section{3 - PROPOSIÇÃO}

objetivo deste trabalho consistiu em:

Avaliar por meio das radiografias submentoniana e póstero-anterior as alterações dentoesqueléticas decorrentes do tratamento ortodôntico da má oclusão de Classe II, subdivisão, com extrações assimétricas, em relação a um grupo controle de oclusão normal. 


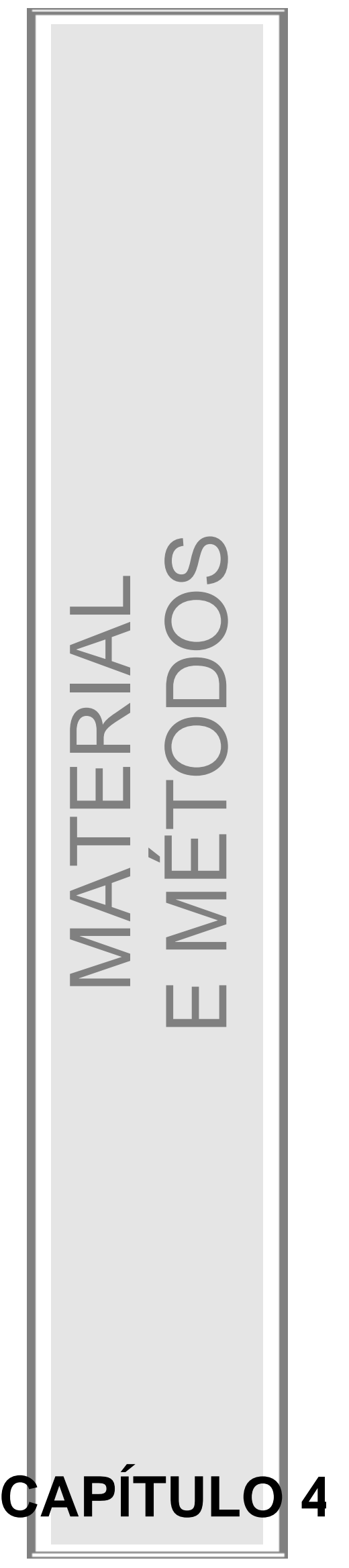




\section{4 - MATERIAL E MÉTODOS}

\section{1 - Material}

amostra consistiu de três grupos, com 30 pacientes cada, sendo dois
grupos experimentais e um controle de oclusão normal. A distribuição da amostra procedeu-se da seguinte maneira:

> grupo 1 - pacientes com Classe II, subdivisão, não tratados;

> grupo 2 - pacientes com Classe II, subdivisão, tratados com extrações assimétricas;

> grupo 3 - pacientes apresentando oclusão normal (controle).

Os pacientes do grupo experimental de número 1 apresentavam má oclusão de Classe II, subdivisão, selecionados dentre aqueles que procuraram tratamento ortodôntico na Disciplina de Ortodontia da Faculdade de Odontologia de Bauru USP. Dezesseis eram do sexo masculino e 14 do feminino, com idade média de 15,76 anos. Já os pacientes do grupo experimental 2 com má oclusão de Classe II, subdivisão tratados com extrações assimétricas foram selecionados dentre aqueles que haviam sido tratados na Disciplina de Ortodontia da Faculdade de Odontologia de Bauru-USP. Treze eram do sexo masculino e 17 do sexo feminino, com idade média de 18,57 anos. Dos 30 pacientes tratados, somente dez pertenceram ao grupo de má oclusão de Classe II, subdivisão não tratado. Os 30 jovens do grupo 3 apresentavam oclusão normal, sendo selecionados dentre estudantes e funcionários da Faculdade de Odontologia de Bauru - USP, que se dispuseram a participar do estudo. Dez eram do sexo masculino e 20 do sexo feminino, com idade média de 22,42 anos.

O grupo 1, de Classe II, subdivisão não tratado e o grupo 3, de oclusão normal já haviam sido selecionados e comparados em pesquisa realizada anteriormente $^{73}$. Desta forma, seus dados foram utilizados neste trabalho para 
auxiliar na interpretação das alterações ocorridas neste tipo de má oclusão, com as sistemáticas de extrações empregadas.

Como critério básico para a seleção da amostra, os pacientes dos grupos experimentais 1 e 2 (antes do tratamento) e os do grupo controle de oclusão normal, deveriam apresentar todos os dentes permanentes superiores e inferiores, em ambos os arcos dentários, até os primeiros molares ${ }^{1,73,98,137,151}$. Alguns critérios adicionais para a seleção dos pacientes dos grupos com má oclusão não tratado e tratado, previamente ao tratamento, foram adotados:

1. Apresentar uma má oclusão de Classe II, subdivisão com relação de Classe I de um lado e Classe II completa do outro;

2. Tolerância de, no máximo, três milímetros de apinhamento simétrico nos arcos dentários superior e/ou inferior;

3. Inexistência de histórico de trauma facial e deformidades craniomaxilofaciais que poderiam causar um crescimento assimétrico das bases ósseas ${ }^{73,98,132,137,159}$;

4. Não deveriam ter sido anteriormente submetidos a tratamento ortodôntico $^{73,98,137}$,

5. Não poderiam apresentar deslocamento mandibular lateral durante o fechamento bucal ${ }^{1,73,98,137,145,151}$.

Ainda para o grupo experimental 2, os casos selecionados foram aqueles submetidos a dois protocolos de extrações assimétricas mencionados a seguir:

Os elementos dentários extraídos assimetricamente deveriam ser um pré-molar superior do lado de Classe II (Figuras 4.A1, 4.A2, 4.A3, 4.A4, 4.A5 e 4.A6) ou dois pré-molares superiores e um pré-molar inferior do lado da Classe I (Figuras 4.B1, 4.B2, 4.B3, 4.B4, 4.B5 e 4.B6);

Todos os casos deveriam apresentar seus tratamentos ortodônticos bem finalizados. 
Estes critérios foram avaliados pela investigadora, por meio de anamnese e exames clínico e radiográfico.

Desta forma, para o grupo 2, selecionaram-se 17 casos tratados com extração de apenas um pré-molar superior e 13 casos com extração de três prémolares. Ambas as terapêuticas objetivaram a coincidência das linhas médias dentárias superior e inferior entre si e com o plano sagital mediano, obtendo-se uma oclusão final com o lado de Classe I, terminando em Classe I de molar e de canino, enquanto que no lado de Classe II, o molar terminou em Classe II e o canino em Classe I. Para os casos de extração de um pré-molar superior, utilizourse ancoragem extrabucal assimétrica que exercia uma maior força no lado da Classe II e para os casos de extração de dois pré-molares superiores e um pré-molar inferior, convencionourse uma ancoragem extrabucal simétrica no arco superior. Estes planejamentos minimizaram a utilização de elásticos intermaxilares de Classe II, Classe III e diagonal anterior, reduzindo o tempo de utilização das ancoragens extra e intrabucal, para a finalização do tratamento, simplificando a biomecânica e corrigindo as assimetrias dentárias ${ }^{73,134}$. 


\section{CASO DE CLASSE II, SUBDIVISÃO TRATADO COM EXTRAÇÃO DE APENAS UM PRÉ-MOLAR SUPERIOR}

INICIAL
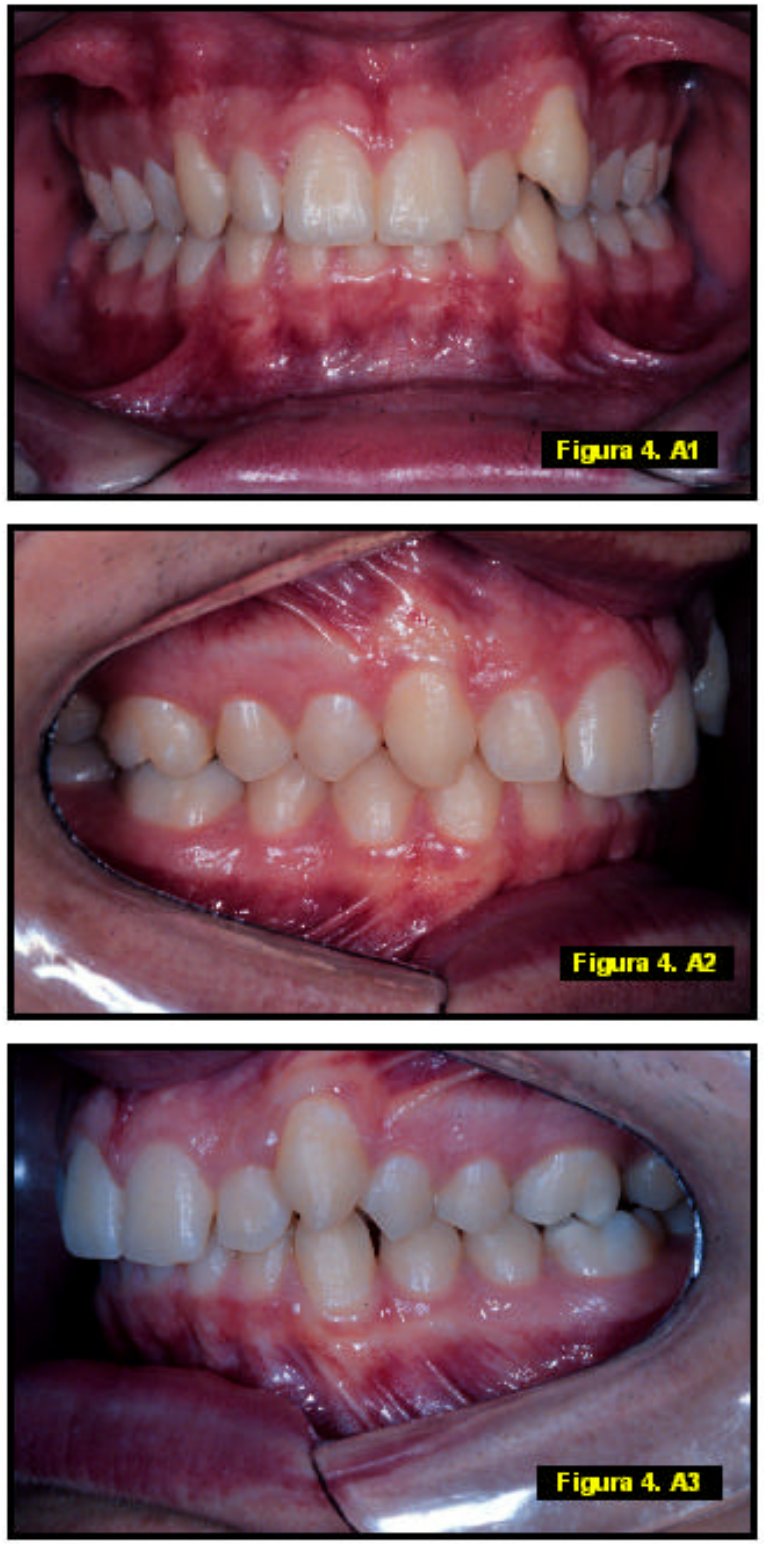

FINAL
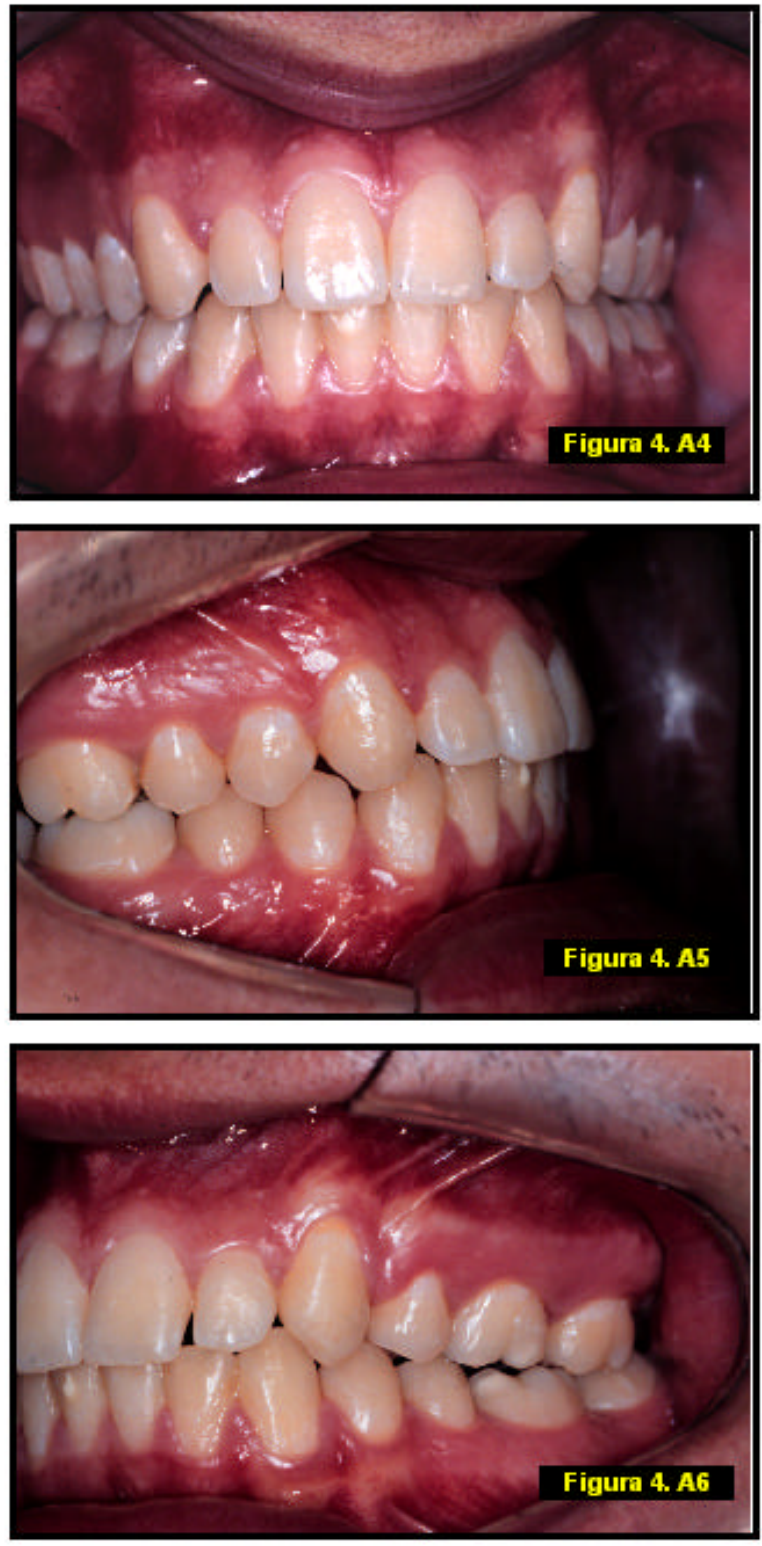


\section{CASO DE CLASSE II, SUBDIVISÃO TRATADO COM EXTRAÇÕES DE TRÊS PRÉ-MOLARES}

INICIAL
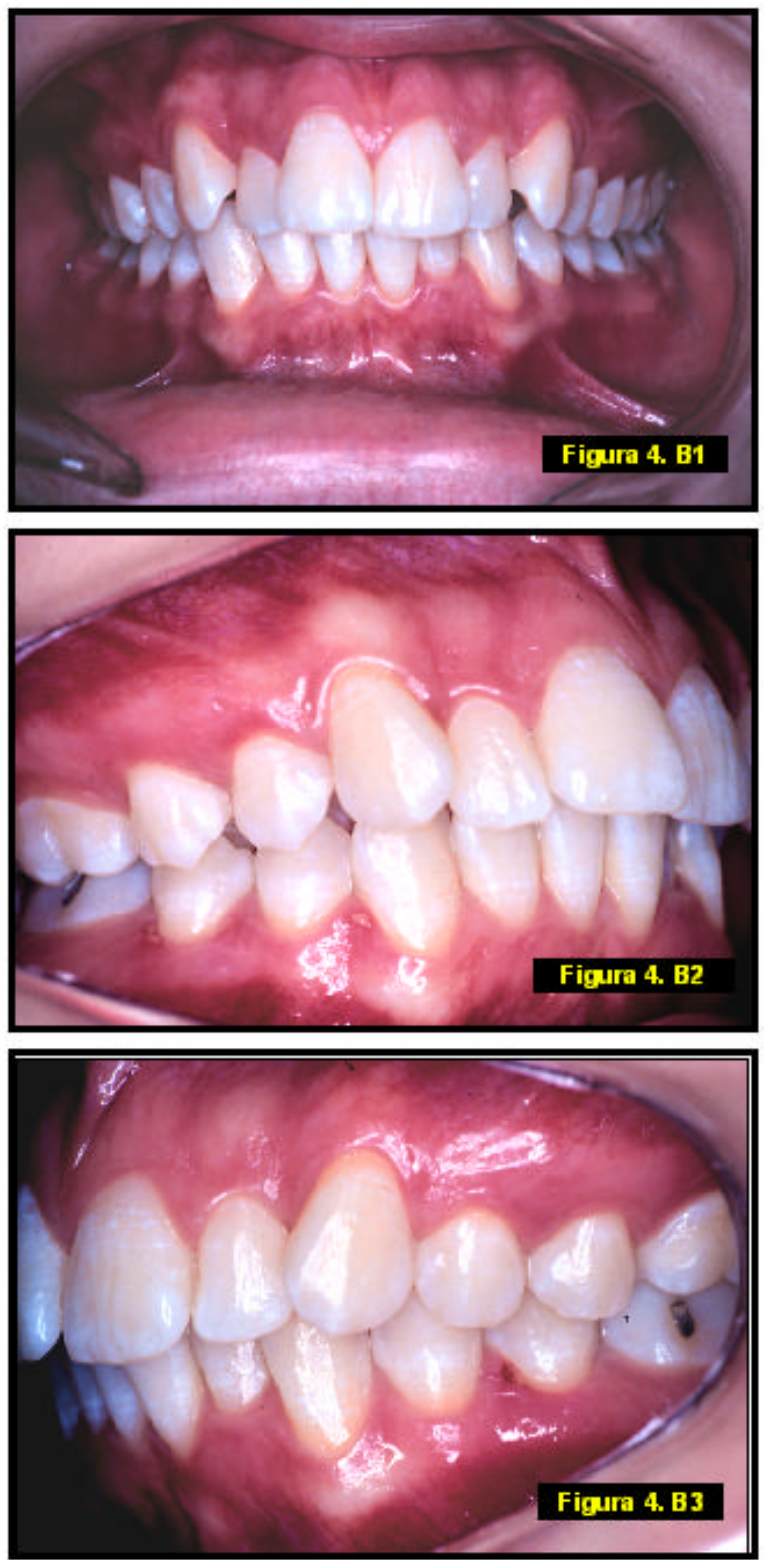

FINAL
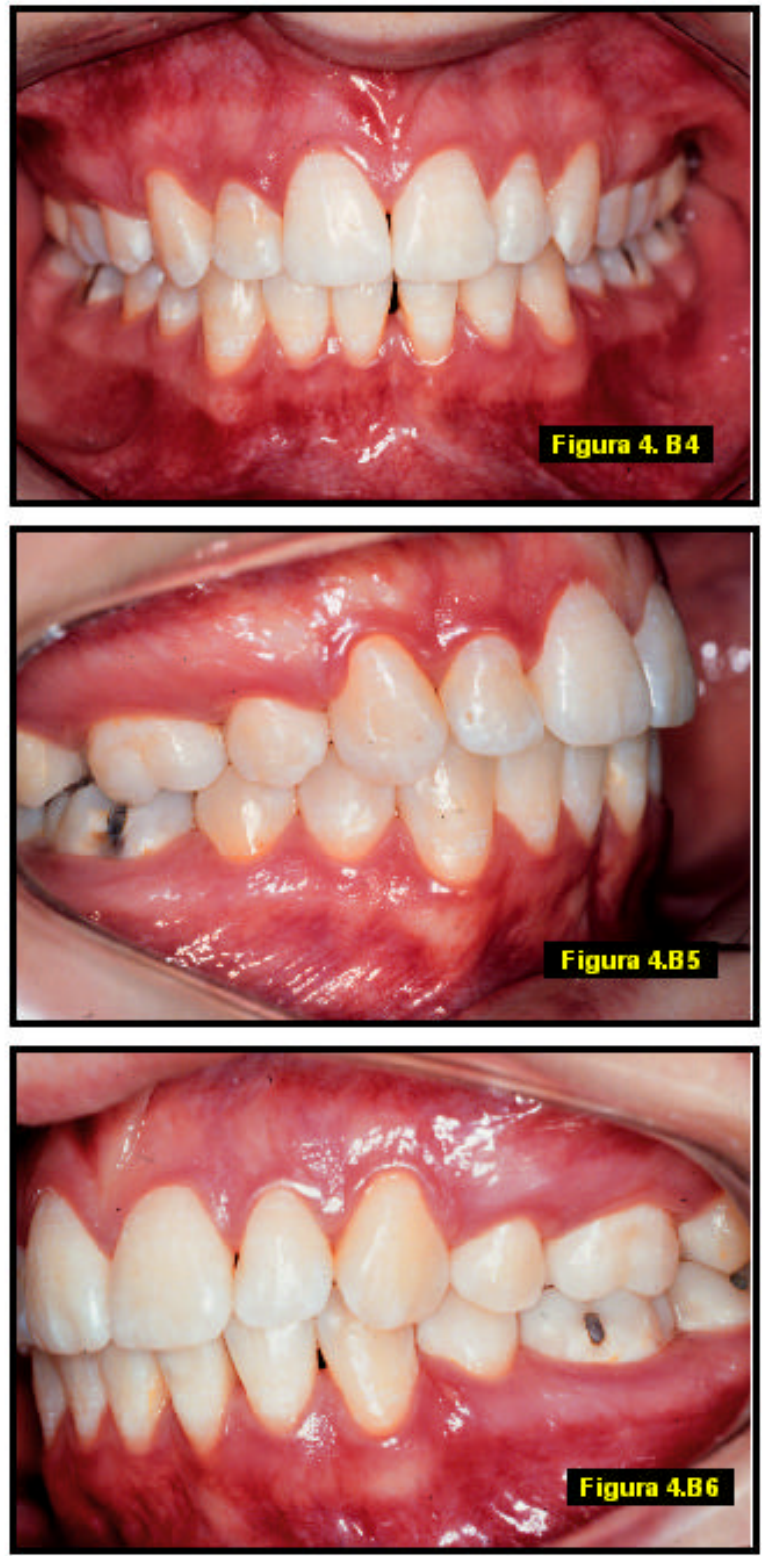


\section{2 - Métodos}

Duas radiografias, uma submentoniana e uma póstero-anterior, foram obtidas de cada indivíduo. As radiografias obtidas, bem como o seu processamento automático foram conduzidos pela investigadora, sendo os traçados anatômicos e a demarcação dos pontos realizados manualmente, em papel de acetato transparente "ultraphan", de tamanho $20,3 \mathrm{~cm} \times 25,4 \mathrm{~cm}$ e $0,07 \mathrm{~mm}$ de espessura, sobre um negatoscópio, em uma sala escurecida. Para melhor delimitação das estruturas anatômicas, adaptourse uma máscara de cartolina preta ao redor da radiografia, de modo a eliminar ao máximo a luminosidade lateral proveniente do negatoscópio. Os traçados cefalométricos e os pontos foram realizados com uma lapiseira provida com grafite $2 \mathrm{~B}$, de $0,5 \mathrm{~mm}$ de diâmetro. Todos os traçados e pontos foram posteriormente conferidos e corrigidos pelo orientador do trabalho, individualmente. Os pontos foram digitalizados por meio de uma mesa digitalizadora Hipad $D T-11^{a}$, conectada a um microcomputador Pentium II - 233 MMX, para a obtenção das grandezas cefalométricas. Para a realização das mensurações dos pontos digitalizados, utilizoutse o programa Dentofacial Planner $7.0^{b}$.

\subsection{1 - Radiografias Submentonianas}

A técnica das radiografias submentonianas baseourse em metodologias já citadas na literatura ${ }^{46,54,84,88,116,125}$. Cada indivíduo foi posicionado sentado em um banco sem encosto de forma que sua cabeça fosse rotacionada para trás, até que o plano de Frankfürt se apresentasse paralelo ao chassis. Como esta posição era bastante desconfortável, causando um certo desequilíbrio, o paciente foi orientado para segurar com as duas mãos, em uma mesa de apoio fixa, posicionada à sua frente. O aparelho utilizado para a radiografia foi o TUR $D 800^{\circ}$, com filme Kodak $X$ Omat $K$ (não interfoliado) e com tempo de exposição de $0,125 \mathrm{~s}$, a $70 \mathrm{kv}$ e $32 \mathrm{ma}$. A distância do ponto focal até as olivas metálicas foi padronizada em $152 \mathrm{~cm}$ e a distância das olivas metálicas até o filme, fixada em $16 \mathrm{~cm}$, o que forneceu um fator de magnificação de $9,55 \%$. Durante a tomada da radiografia, os pacientes deveriam manter os dentes em máxima intercuspidação habitual, sob ligeira pressão.

\footnotetext{
${ }^{a}$ Houston Instruments, Hous ton, Texas

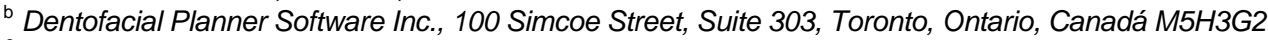

c Dresden, Alemanha (VEB Transformatoren - und Röntgenwerk < Hermann Matern >)
} 
Para o traçado das estruturas anatômicas de interesse, demarcação dos pontos e linhas e medição das grandezas cefalométricas, utilizou-se a análise de RITUCCI; BURSTONE ${ }^{46,136}$, com algumas modificações de interesse para esta pesquisa.

\subsubsection{1 - Estruturas Anatômicas (Figura 4.1):}

1 Forame Magno

2 Forames espinhosos

3 Olivas metálicas

4 Mandíbula (incluindo côndilos, ângulos goníacos e processos coronóides)

5 Abóbada craniana posterior

6 Arcos zigomáticos

7 Abóbada craniana anterior

8 Fissuras pterigomaxilares

9 Vômer

10 Primeiros molares superiores

11 Primeiros molares inferiores

12 Incisivos centrais superiores

13 Incisivos centrais inferiores

\subsubsection{2 - Pontos de Referência (Figura 4.2):}

1 O centro medial da oliva metálica direita.

2 O centro medial da oliva metálica esquerda.

3 Gônio direito (GOD) - Ponto médio mediolateralmente na borda posterior do ângulo goníaco direito.

4 Gônio esquerdo (GOE) - Ponto médio mediolateralmente na borda posterior do ângulo goníaco esquerdo.

5 Ponto condilar médio direito (PCMD) - Ponto médio de uma linha que conecta os pontos medial e lateral da cabeça condilar direita. 
6 Ponto condilar médio esquerdo (PCME) - Ponto médio de uma linha que conecta os pontos medial e lateral da cabeça condilar esquerda.

7 Ponto condilar medial direito (PCMD) - O ponto onde uma linha traçada paralelamente ao corpo mandibular toca a porção medial do côndilo direito.

8 Ponto condilar medial esquerdo (PCME) - O ponto onde uma linha traçada paralelamente ao corpo mandibular toca a porção medial do côndilo esquerdo.

9 Ponto condilar lateral direito (PCLD) - O ponto onde uma linha traçada paralelamente ao corpo mandibular toca a porção lateral do côndilo direito.

10 Ponto condilar lateral esquerdo (PCLE) - O ponto onde uma linha traçada paralelamente ao corpo mandibular toca a porção lateral do côndilo esquerdo.

11 Distal do primeiro molar inferior direito (DPMID) - O ponto mais distal, alinhado com o sulco mesiodistal central do primeiro molar inferior direito.

12 Distal do primeiro molar inferior esquerdo (DPMIE) - O ponto mais distal, alinhado com o sulco mesiodistal central do primeiro molar inferior esquerdo.

13 Processo coronóide direito (PCD) - O ponto mais anterior, em relação à linha condilar, no processo coronóide direito.

14 Processo coronóide esquerdo (PCE) - O ponto mais anterior, em relação à linha condilar, no processo coronóide esquerdo.

15 Linha média mandibular (LMM) - O ponto mais anterior do corpo da mandíbula, consistindo num ponto esquelético.

16 Linha média dentária inferior (LMDI) - O ponto de contato entre as superfícies mesiais das coroas dos incisivos centrais inferiores.

17 Forame espinhoso direito (FED) - O centro geométrico do forame espinhoso direito.

18 Forame espinhoso esquerdo (FEE) - O centro geométrico do forame espinhoso esquerdo.

19 Linha média dentária superior (LMDS) - O ponto de contato entre as superfícies mesiais das coroas dos incisivos centrais superiores.

20 Vômer anterior (NA) - Intersecção do vômer com uma linha que conecta os pontos angulares direito e esquerdo. 
21 Vômer posterior (VP) - Intersecção do vômer com uma linha que conecta os pontos das fissuras pterigomaxilar (PTM) direita e esquerda.

22 Angulare direito $(A D)^{12,13}$ - Ponto mais anterior, em relação à linha PTM, das opacidades triangulares presentes no ângulo orbital externo, onde as bordas superior e inferior da órbita se encontram e onde o arco zigomático se insere.

23 Angulare esquerdo $(A E)^{12,13}$ - Vide ponto 22.

24 Buccale direito $(B D)^{12,13}$ - Ponto na superfície interna do arco zigomático direito, onde o mesmo se curva mesialmente e, em seguida, para trás.

25 Buccale esquerdo $(\mathrm{BE})^{12,13}$ - Ponto na superfície interna do arco zigomático esquerdo, onde o mesmo se curva para medial e, em seguida, para trás.

26 Fossa craniana média direita (FCMD) - Ponto mais anterior, em relação à linha interespinhosos, na asa menor do osso esfenóide.

27 Fossa craniana média esquerda (FCME) - Vide ponto 26.

28 Fissura pterigomaxilar dreita (FPTMD) - Ponto mais medial e posterior da fissura pterigomaxilar direita. A linha PTM conecta os pontos PTMD e PTME.

29 Fissura pterigomaxilar esquerda (FPTME) - Ponto mais medial e posterior da fissura pterigomaxilar esquerda.

30 Zygion direito (ZD) - Ponto localizado na intersecção da borda lateral do arco zigomático direito, obtido pelo prolongamento da linha PTM e traçado pela secção de maior largura da distância bizigomática.

31 Zygion esquerdo (ZE) - Ponto localizado na intersecção da borda ateral do arco zigomático esquerdo, obtido pelo prolongamento da linha PTM e traçado pela secção de maior largura da distância bizigomática.

32 Abóbada craniana anterior direita (ACAD) - Ponto onde a borda lateral do crânio é interceptada por uma linha que conecta os pontos zygion direito e esquerdo.

33 Abóbada craniana anterior esquerda (ACAE) - Ponto onde a borda lateral do crânio é interceptada por uma linha que conecta os pontos zygion direito e esquerdo.

34 Básio $(\mathrm{Ba})$ - Ponto mais anterior, em relação à linha interespinhosos, na borda anterior do forame magno. 
35 Opístion (Op) - Ponto mais posterior, em relação à linha interespinhosos, na borda posterior do forame magno.

36 Abóbada craniana posterior direita (ACPD) - Ponto onde a borda lateral direita da abóbada craniana é interceptada por uma linha paralela à linha interespinhosos, traçada pela abóbada craniana, em sua secção de maior largura.

37 Abóbada craniana posterior esquerda (ACPE) - Ponto onde a borda lateral esquerda da abóbada craniana é interceptada por uma linha paralela à linha interespinhosos, traçada pela abóbada craniana, em sua secção de maior largura.

38 Contorno médio da mandíbula do lado direito (CMMD) - Ponto mais medial e posterior, no contorno médio do corpo da mandíbula, do lado direito.

39 Contorno médio da mandíbula do lado esquerdo (CMME) - Ponto mais medial e posterior, no contorno médio do corpo da mandíbula, do lado esquerdo.

40 Ponto médio do eixo transespinhosos (PMETE) - Ponto médio na linha que une o centro geométrico dos pontos dos forames espinhosos.

41 Ponto perpendicular ao eixo transespinhosos (PERPETE) - Ponto demarcado perpendicularmente ao eixo transforame espinhoso, à frente do mento, eqüidistante dos forames espinhosos (este e os outros pontos perpendiculares aos eixos das abscissas foram utilizados apenas para possibilitar o traçado dos eixos das ordenadas).

42 Ponto perpendicular ao eixo transcondilar (PERPETC) - Ponto demarcado perpendicularmente ao eixo transcondilar, à frente do mento, eqüidistante dos pontos médios condilares.

43 Ponto médio do eixo transcondilar (PMETC) - Ponto médio entre os dois pontos condilares médios, no eixo transcondilar.

44 Ponto médio do eixo transpterigomaxilar (PMETPTM) - O ponto médio entre os dois pontos FPTM (fissura pterigomaxilar, direita e esquerda), no eixo transpterigomaxilar.

45 Ponto perpendicular ao eixo transpterigomaxilar (PERPETPTM) - Um ponto demarcado perpendicularmente ao eixo transpterigomaxilar, à frente do mento, eqüidistante dos pontos FPTM. 
46 Ponto médio do eixo transmolar (PMETM) - Ponto médio entre os dois pontos DPMI (distal do primeiro molar inferior direito e esquerdo), no eixo transmolar.

47 Ponto perpendicular ao eixo transmolar (PERPETM) - Um ponto demarcado perpendicularmente ao eixo transmolar, à frente do mento, eqüidistante dos pontos DPMID e DPMIE.

48 Centro da face vestibular do primeiro molar inferior direito (CVPMID).

49 Centro da face vestibular do primeiro molar inferior esquerdo (CVPMIE).

50 Borda mandibular direita (BMD) - Ponto onde a linha perpendicular à face vestibular do primeiro molar inferior direito intercepta a borda mandibular.

51 Borda mandibular esquerda (BME) - Ponto onde a linha perpendicular à face vestibular do primeiro molar inferior esquerdo intercepta a borda mandibular.

52 Ponto na distal do primeiro molar superior direito (PDMSD) - Ponto mais distal, alinhado com o sulco principal do primeiro molar superior direito.

53 Ponto na distal do primeiro molar superior esquerdo (PDMSE) - Ponto mais distal, alinhado com o sulco principal do primeiro molar superior esquerdo.

54 Centro da face vestibular do primeiro molar superior direito (CVPMSD).

55 Centro da face vestibular do primeiro molar superior esquerdo (CVPMSE).

56 Borda mandibular superior direita (BMSD) - Ponto onde a perpendicular à face vestibular do primeiro molar superior direito intercepta a borda mandibular.

57 Borda mandibular superior esquerda (BMSE) - Ponto onde a perpendicular à face vestibular do primeiro molar superior esquerdo intercepta a borda mandibular.

58 Ponto médio do eixo transmolar superior (PMETMS) - Ponto médio entre os dois pontos nas distais dos primeiros molares superiores direito e esquerdo no eixo transmolar superior.

59 Ponto perpendicular ao eixo transmolar superior (PERPETMS) - Ponto demarcado perpendicularmente ao eixo transmolar superior, à frente do mento, eqüidistante dos pontos DPMSD e DPMSE. 


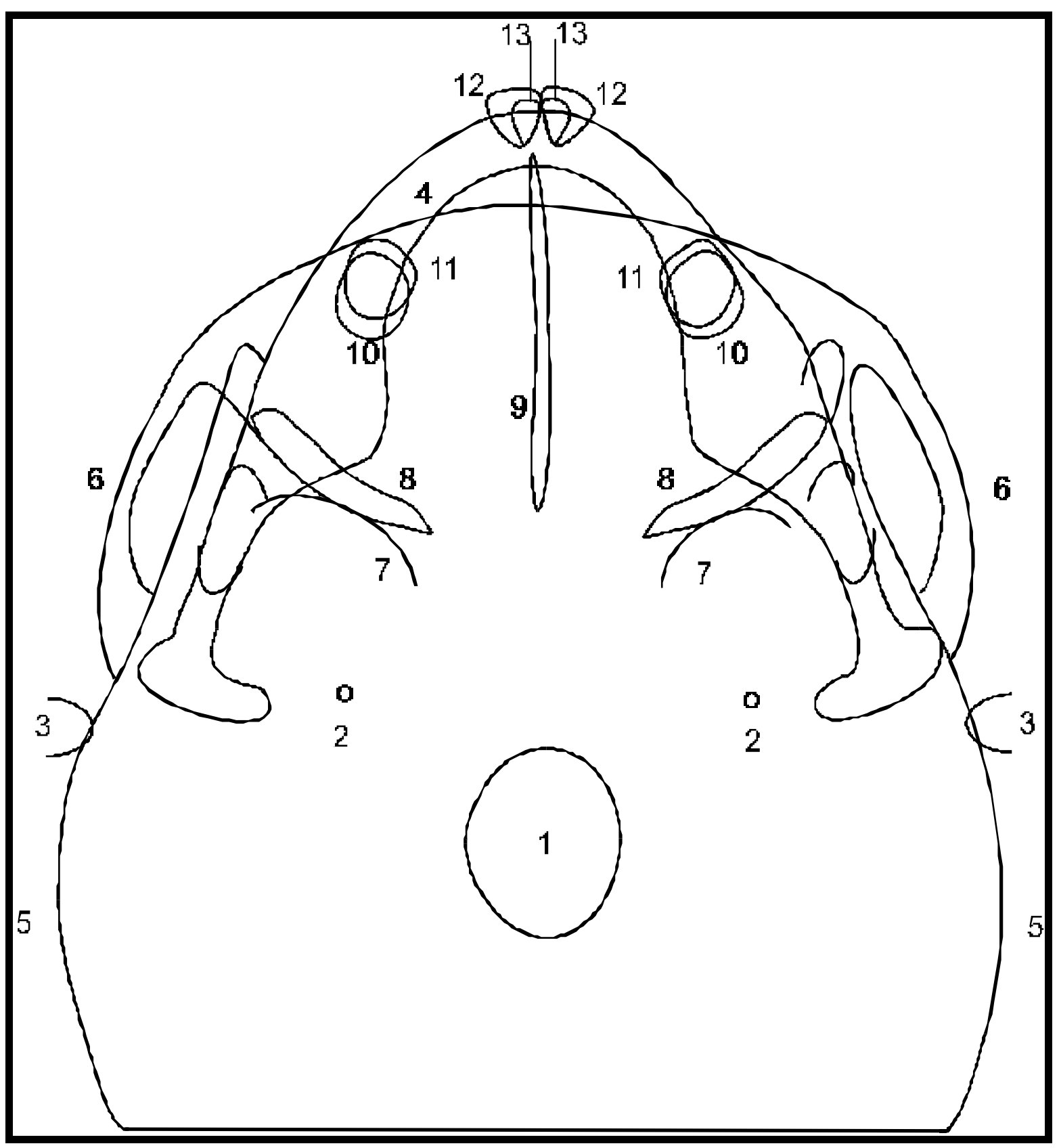

FIGURA 4.1 - Estruturas Anatômicas da Radiografia Submentoniana*

${ }^{*}$ FONTE: Figura reproduzida da pesquisa de JANSON ${ }^{73}$. 


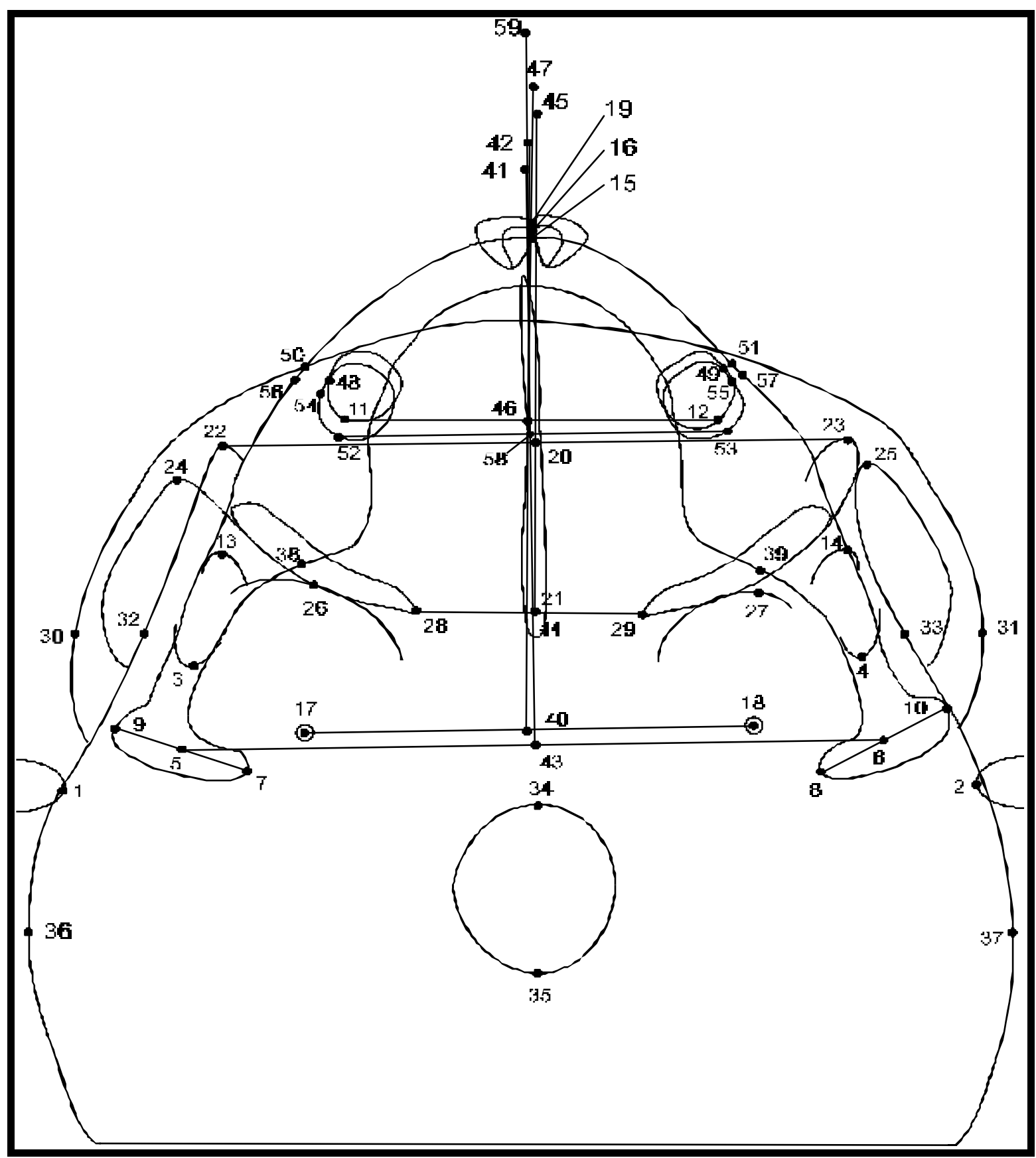

FIGURA 4.2 - Pontos de Referência da Radiografia Submentoniana*

\footnotetext{
* FONTE: Figura reproduzida da pesquisa de JANSON ${ }^{73}$.
} 


\subsubsection{3 - Linhas (Figura 4.3):}

A Eixo Transcondilar - ETC - linha que passa pelos pontos PCMD e PCME, 5-6.

B Eixo Transespinhosos - ETE - linha que passa pelos pontos FED e FEE, 1718.

C Eixo Transpterigomaxilar - ETPTM - linha que passa pelos pontos FPTMD e FPTME, 28-29.

D Eixo Transmolares Inferiores - ETMI - linha que passa pelos pontos DPMID e DPMIE, 11-12.

E Eixo Transmolares Superiores - ETMS - linha que passa pelos pontos DPMSD e DPMSE, 52-53.

F Eixo Intercondilar - EIC - linha perpendicular ao eixo transcondilar, passando pelo ponto médio do mesmo, 42-43.

G Eixo Interespinhosos - EIE - linha perpendicular ao eixo transespinhosos, passando pelo ponto médio do mesmo, 40-41.

H Eixo Interpterigomaxilar - EIPTM - linha perpendicular ao eixo transpterigomaxilar, passando pelo ponto médio do mesmo, 44-45.

I Eixo Intermolares inferiores - EIMI - linha perpendicular ao eixo transmolar inferior, passando pelo ponto médio do mesmo, 46-47.

J Eixo Intermolares superiores - EIMS - linha perpendicular ao eixo transmolar superior, passando pelo ponto médio do mesmo, 58-59. 


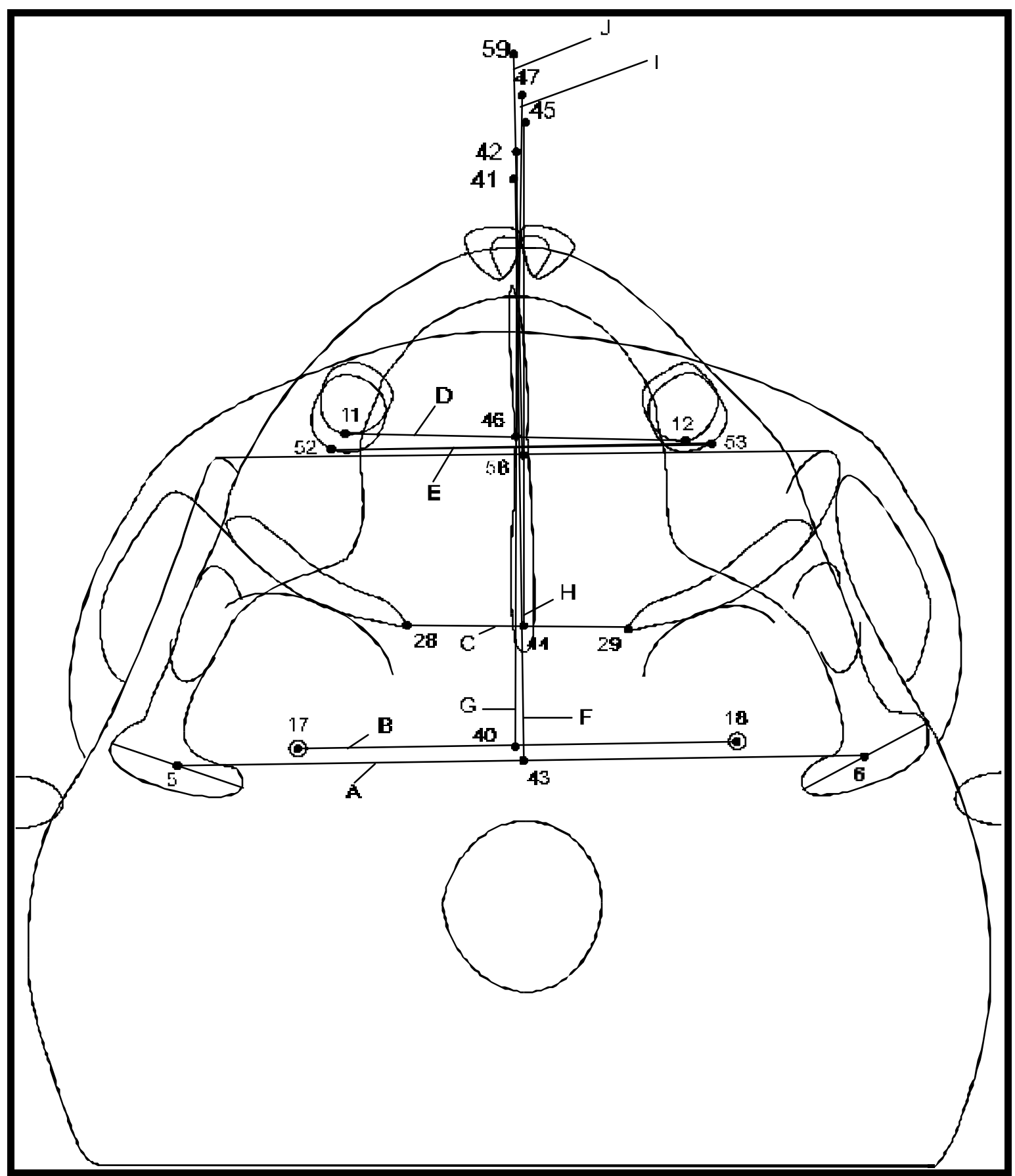

FIGURA 4.3 - Linhas da Radiografia Submentoniana*

\footnotetext{
* FONTE: Figura reproduzida da pesquisa de JANSON ${ }^{73}$.
} 


\subsubsection{4 - Grandezas Cefalométricas}

Para se avaliar a assimetria das estruturas craniodentárias em relação aos diferentes sistemas de coordenadas utilizourse, neste trabalho, o método proposto por RITUCCI; BURSTONE ${ }^{136}$, com algumas modificações. Os sistemas de coordenadas utilizados consistiram no sistema de coordenadas mandibulares, do assoalho craniano, zigomaticomaxilar e dentárias. Além disto, foram acrescidas as medidas angulares entre as abscissas dos sistemas de coordenadas e algumas variáveis adicionais.

Nos sistemas de coordenadas foram estabelecidos dois eixos perpendiculares entre si, para a avaliação da posição ântero-posterior e lateral das estruturas, em relação a estes eixos. Desta forma, no sistema de coordenadas mandibulares, estabeleceu-se o eixo transcondilar, passando pelo ponto médio condilar e servindo na avaliação da simetria da posição ântero-posterior das estruturas mandibulares, e o eixo intercondilar, perpendicular ao eixo transcondilar, a partir do ponto médio deste último, para a avaliação da simetria da posição transversal destas estruturas. De maneira análoga, foram construídos os eixos transespinhosos e interespinhosos, para o sistema de coordenadas do assoalho craniano; os eixos transpterigomaxilar e interpterigomaxilar, para o sistema de coordenadas zigomaticomaxilares e os eixos transmolares e intermolares superiores e inferiores, para o sistema de coordenadas dentárias. Após a obtenção das grandezas para as variáveis dos lados direito e esquerdo, obteve-se a diferença entre elas, sendo todas as variáveis discriminadas a seguir.

Em consonância com a metodologia adotada por $\mathrm{JANSON}^{73}$, as radiografias submentonianas e póstero-anteriores do grupo com oclusão normal foram sempre posicionadas com o lado direito do paciente coincidente com o lado esquerdo do observador, considerando que o profissional se encontrava posicionado à frente do paciente. Entretanto, as radiografias dos grupos 1 e 2 foram posicionadas de forma que o lado com Classe I estivesse sempre do lado esquerdo do observador. Realizou-se este procedimento para que o programa de cefalometria calculasse as diferenças entre as medidas bilaterais subtraindo sempre os valores do lado 
esquerdo, do caso em questão, dos valores do lado direito (nos casos de oclusão normal) e os valores do lado de Classe II, dos do lado da Classe I (nos casos de Classe II, subdivisão não tratados e tratados com extrações assimétricas). Os desvios das estruturas centrais, na radiografia submentoniana, foram calculados de forma que um valor positivo era atribuído se a estrutura estivesse localizada à direita (esquerda do observador) do eixo sagital e um valor negativo, se a estrutura estivesse à esquerda (direita do observador). Na radiografia póstero-anterior, adotou-se o critério contrário, por motivos técnicos do programa de cefalometria.

Tanto para as diferenças entre as medidas dos lados direito e esquerdo como para as distâncias horizontais aos planos de referência médios, utilizaram-se valores absolutos. Desta forma, eliminou-se a possibilidade de valores de diferença positivos e negativos se cancelarem no cálculo das médias para cada grupo 5 . Entretanto, os valores reais para cada variável foram calculados para elucidar a direção do desvio esquelético ou dentário, quando este estava presente ${ }^{73}$ (tabelas 1 a 7).

Realizou-se a disposição das radiografias, da forma anteriormente mencionada, para que as leituras dos valores reais, não fossem influenciadas, mas para o cálculo dos valores absolutos, este protocolo poderia ter sido dispensado.

\subsubsection{1 - Sistema de Coordenadas Mandibulares}

\subsection{1 - Ântero-posterior (Figura 4.4):}

1 Gônio direito ao eixo transcondilar (GOD-ETC).

2 Gônio esquerdo ao eixo transcondilar (GOE-ETC).

3 Ponto do processo coronóide direito ao eixo transcondilar (PCD-ETC).

4 Ponto do processo coronóide esquerdo ao eixo transcondilar (PCE-ETC).

5 Ponto distal do primeiro molar inferior direito ao eixo transcondilar (PDMID ETC).

6 Ponto distal do primeiro molar inferior esquerdo ao eixo transcondilar (PDMIE ETC). 
7 Ponto distal do primeiro molar superior direito ao eixo transcondilar (PDMSDETC).

8 Ponto distal do primeiro molar superior esquerdo ao eixo transcondilar (PDMSE-ETC).

\subsection{2 - Transverso (Figura 4.5):}

9 Gônio direito ao eixo intercondilar (GOD-EIC).

10 Gônio esquerdo ao eixo intercondilar (GOE-EIC).

11 Ponto do processo coronóide direito ao eixo intercondilar (PPCD-EIC).

12 Ponto do processo coronóide esquerdo ao eixo intercondilar (PPCE-EIC).

13 Ponto distal do primeiro molar inferior direito ao eixo intercondilar (PDMID $\mathrm{EIC)}$.

14 Ponto distal do primeiro molar inferior esquerdo ao eixo intercondilar (PDMIE EIC).

15 Ponto distal do primeiro molar superior direito ao eixo intercondilar (PDMSDEIC).

16 Ponto distal do primeiro molar superior esquerdo ao eixo intercondilar (PDMSE-EIC).

17 Linha média mandibular ao eixo intercondilar (LMM-EIC).

18 Linha média dentária inferior ao eixo intercondilar (LMDFEIC).

19 Linha média dentária superior ao eixo intercondilar (LMDFEIC).

\subsubsection{2 - Sistema de Coordenadas do Assoalho Craniano}

\subsection{1 - Ântero-posterior (Figura 4.6):}

20 Ponto condilar médio direito ao eixo transespinhosos (PCMD-ETE).

21 Ponto condilar médio esquerdo ao eixo transespinhosos (PCME-ETE).

22 Gônio direito ao eixo transespinhosos (GOD-ETE).

23 Gônio esquerdo ao eixo transespinhosos (GOE-ETE).

24 Ponto no processo coronóide direito ao eixo transespinhosos (PPCD-ETE).

25 Ponto no processo coronóide esquerdo ao eixo transespinhosos (PPCE-ETE). 
26 Ponto na distal do primeiro molar inferior direito ao eixo transespinhosos (PDMID-ETE).

27 Ponto na distal do primeiro molar inferior esquerdo ao eixo transespinhosos (PDMIE-ETE).

28 Ponto na distal do primeiro molar superior direito ao eixo transespinhosos (PDMSD-ETE).

29 Ponto na distal do primeiro molar superior esquerdo ao eixo transespinhosos (PDMSE-ETE).

\subsection{2 - Transverso (Figura 4.7):}

30 Ponto condilar médio direito ao eixo interespinhosos (PCMD-EIE).

31 Ponto condilar médio esquerdo ao eixo interespinhosos (PCME-EIE).

32 Gônio direito ao eixo interespinhosos (GOD-EIE).

33 Gônio esquerdo ao eixo interespinhosos (GOE-EIE).

34 Ponto no processo coronóide direito ao eixo interespinhosos (PPCD-EIE).

35 Ponto no processo coronóide esquerdo ao eixo interespinhosos (PPCE-EIE).

36 Ponto distal do primeiro molar inferior direito ao eixo inte respinhosos (PDMID EIE).

37 Ponto distal do primeiro molar inferior esquerdo ao eixo interespinhosos (PDMIE-EIE).

38 Ponto distal do primeiro molar superior direito ao eixo interespinhosos (PDMSD-EIE).

39 Ponto distal do primeiro molar superior esquerdo ao eixo interespinhosos (PDMSE-EIE).

40 Linha média mandibular ao eixo interespinhosos (LMM-EIE).

41 Linha média dentária inferior ao eixo interespinhosos (LMDHEIE).

42 Linha média dentária superior ao eixo interespinhosos (LMDS-EIE). 


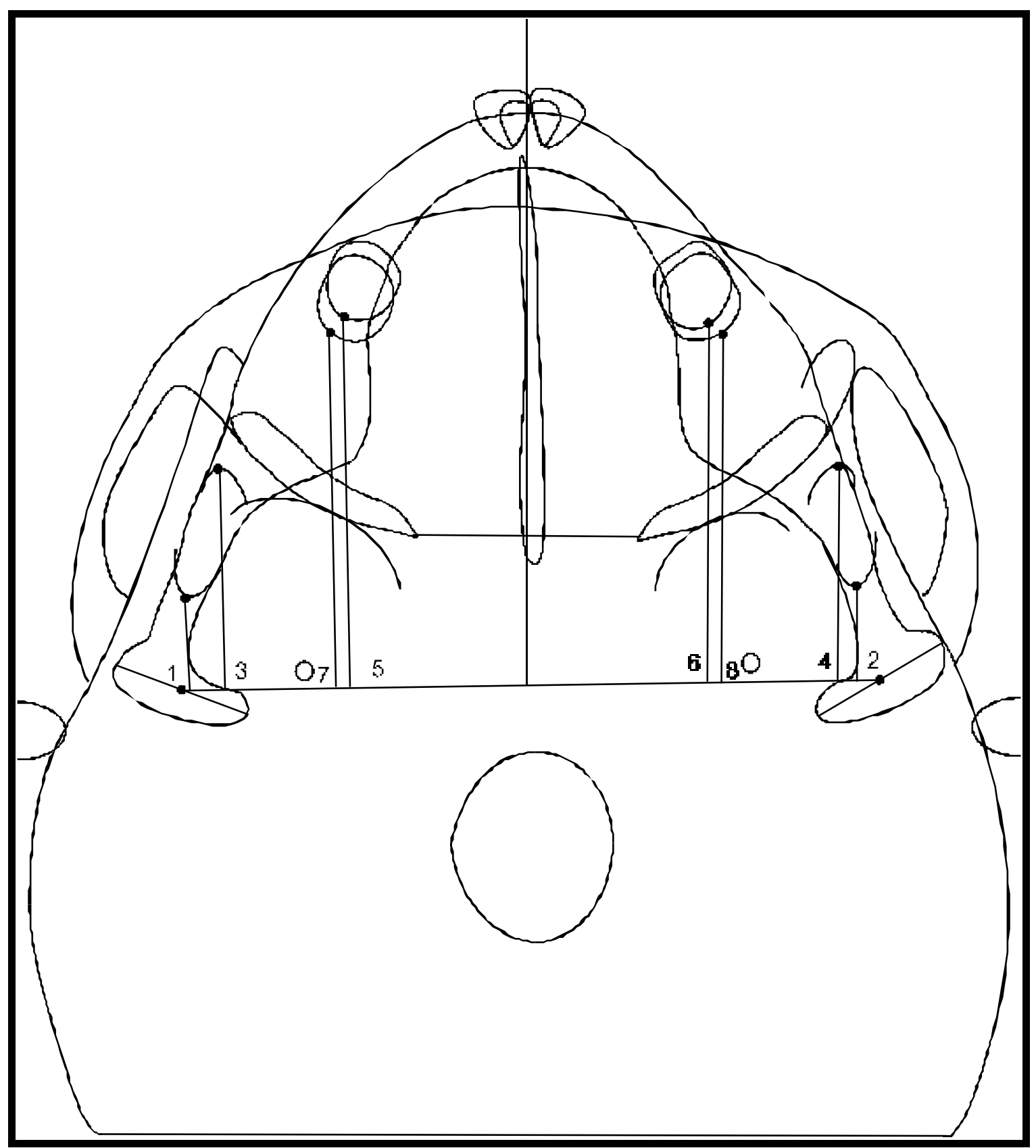

FIGURA 4.4 - Grandezas Cefalométricas da Radiografia Submentoniana*

Sistema de Coordenadas Mandibulares - Ântero-Posterior

\footnotetext{
* FONTE: Figura reproduzida da pesquisa de JANSON ${ }^{73}$.
} 


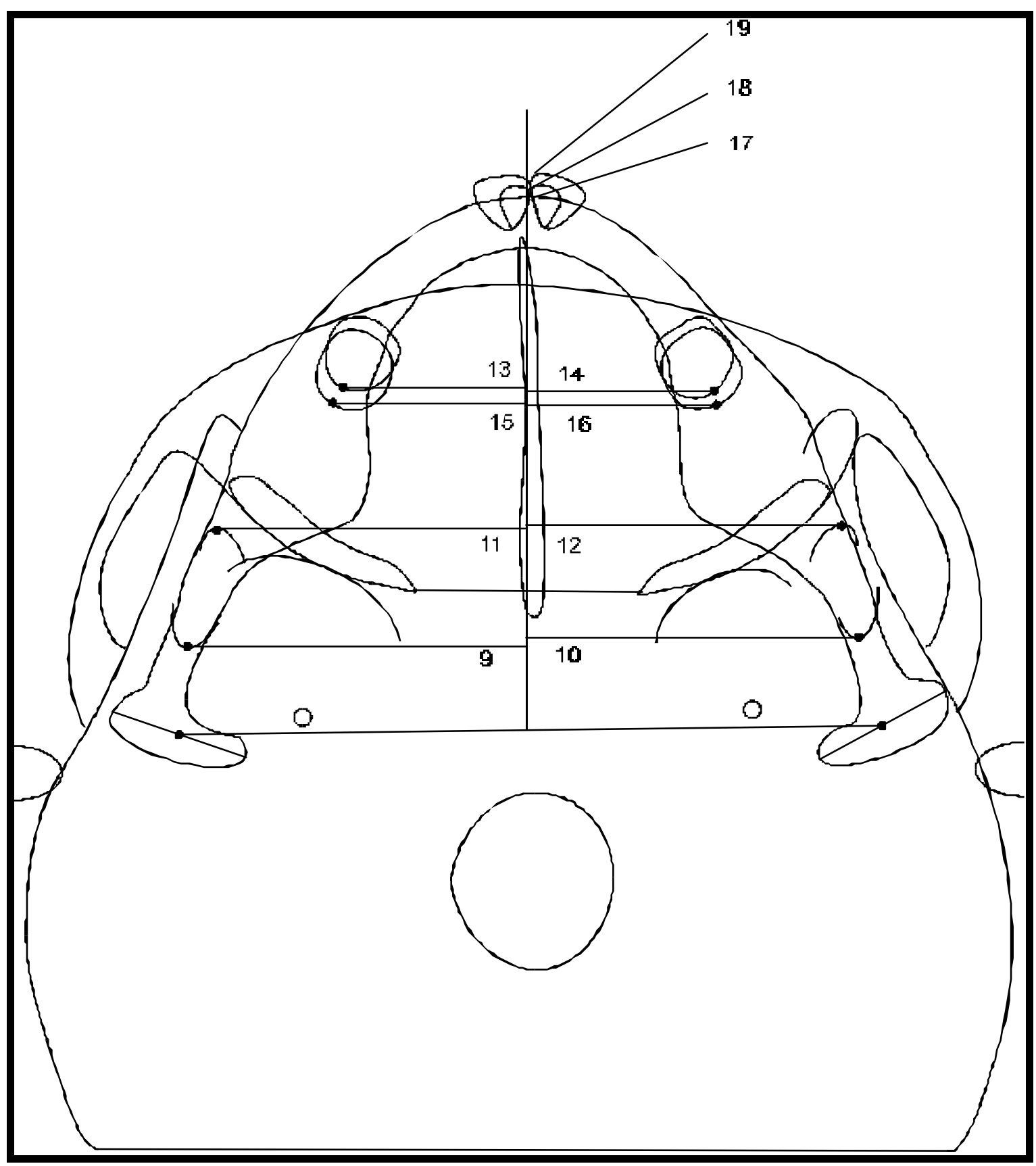

FIGURA 4.5 - Grandezas Cefalométricas da Radiografia Submentoniana* Sistema de Coordenadas Mandibulares - Transverso

\footnotetext{
* FONTE: Figura reproduzida da pesquisa de JANSON ${ }^{73}$.
} 


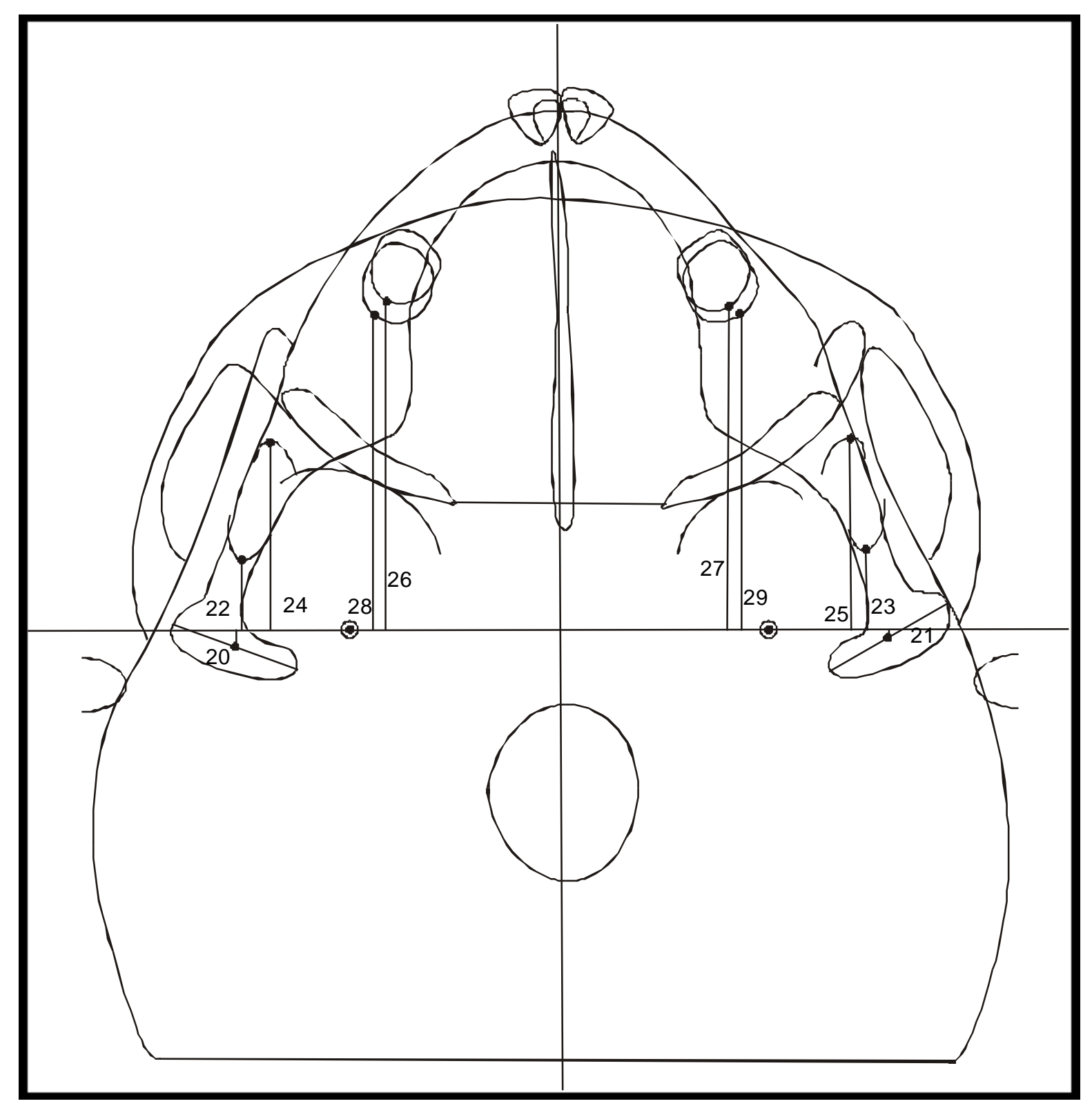

FIGURA 4.6 - Grandezas Cefalométricas da Radiografia Submentoniana*

Sistema de Coordenadas do Assoalho Craniano - Ântero-Posterior

* FONTE: Figura reproduzida da pesquisa de JANSON ${ }^{73}$. 


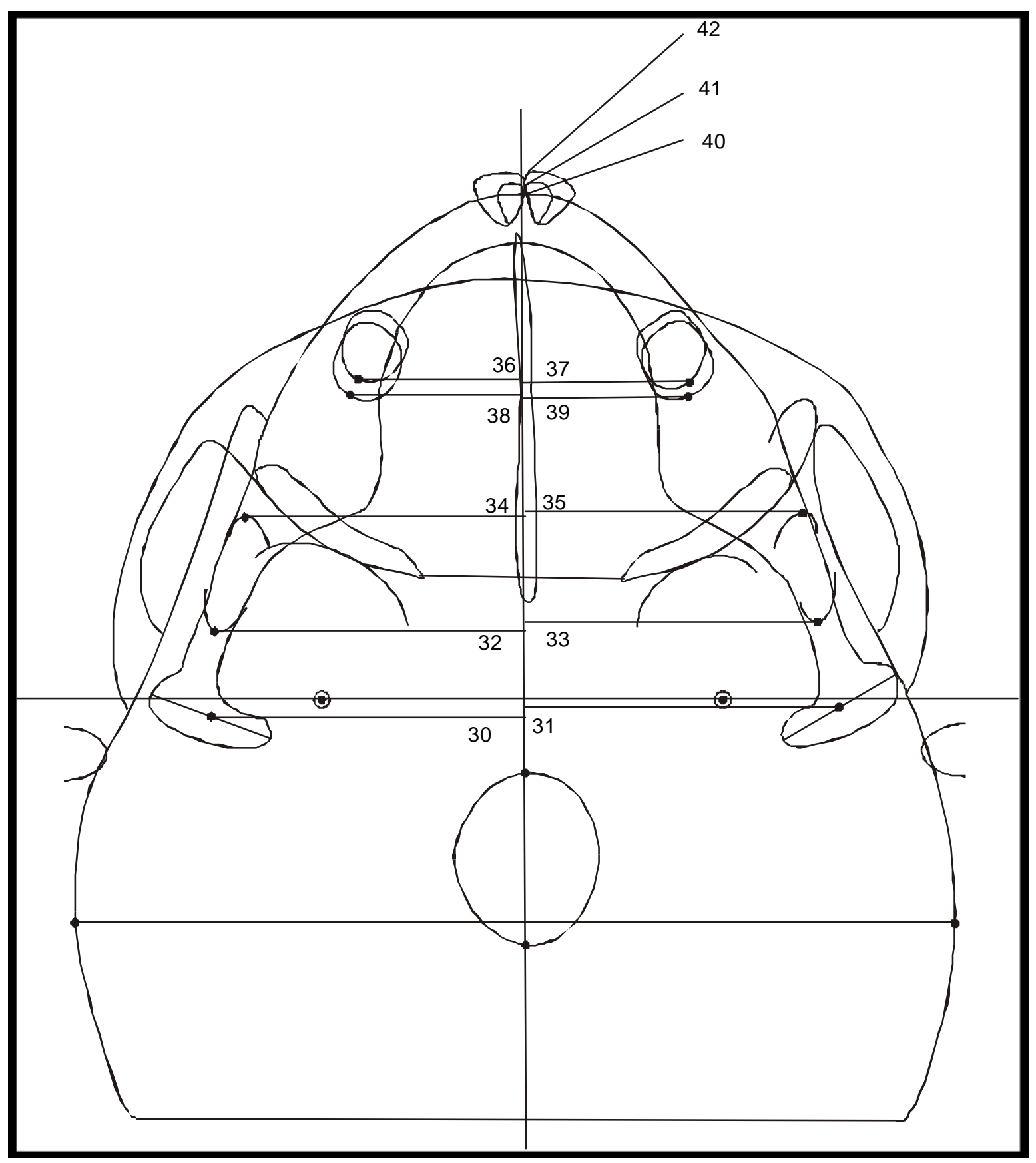

FIGURA 4.7 - Grandezas Cefalométricas da Radiografia Submentoniana* Sistema de Coordenadas do Assoalho Craniano - Transverso

\footnotetext{
* FONTE: Figura reproduzida da pesquisa de $\mathrm{JANSON}^{73}$.
} 


\subsubsection{3 - Sistema de Coordenadas do Complexo Zigomaticomaxilar}

\subsection{1 - Ântero-posterior (Figura 4.8):}

43 Ponto distal do primeiro molar inferior direito ao eixo transpterigomaxilar (PDMID-ETPTM).

44 Ponto distal do primeiro molar inferior esquerdo ao eixo transpterigomaxilar (PDMIE-ETPTM).

45 Ponto distal do primeiro molar superior direito ao eixo transpterigomaxilar (PDMSD-ETPTM).

46 Ponto distal do primeiro molar superior esquerdo ao eixo transpterigomaxilar (PDMSE-ETPTM).

\subsection{2 - Transverso (Figura 4.9):}

47 Ponto vômer anterior ao eixo interpterigomaxilar (PVA-EIPTM).

48 Ponto vômer posterior ao eixo interpterigomaxilar (PVP-EIPTM).

49 Ponto distal do primeiro molar inferior direito ao eixo interpterigomaxilar (PDMID-EIPTM).

50 Ponto distal do primeiro molar inferior esquerdo ao eixo interpterigomaxilar (PDMIE-EIPTM).

51 Ponto distal do primeiro molar superior direito ao eixo interpterigomaxilar (PDMSD-EIPTM).

52 Ponto distal do primeiro molar superior esquerdo ao eixo interpterigomaxilar (PDMSE-EIPTM).

53 Linha média dentária superior ao eixo interpterigomaxilar (LMDS-EIPTM).

54 Linha média mandibular ao eixo interpterigomaxilar (LMM-EIPTM).

55 Linha média dentária inferior ao eixo interpterigomaxilar (LMDFEIPTM).

\subsubsection{4 - Sistema de Coordenadas Dentárias (Figura 4.10):}

\subsection{1 - Transverso:}

56 Linha média dentária inferior ao eixo intermolares (LMDFEIMI).

57 Linha média mandibular ao eixo intermolares (LMM-EIMI).

58 Linha média dentária superior ao eixo intermolares (LMDS-EIMI).

59 Linha média dentária inferior ao eixo intermolares superiores (LMDIEIMS). 
60 Linha média dentária superior ao eixo intermolares superiores (LMDS-EIMS).

61 Linha média mandibular ao eixo intermolares superiores (LMM-EIMS).

\subsubsection{5 - Medidas angulares entre as abscissas dos sistemas de coordenadas} (Figura 4.11):

62 Ângulo entre os eixos interespinhosos e intercondilar (EIE.EIC).

63 Ângulo entre o eixo transespinhosos e o eixo transcondilar (ETE.ETC).

64 Ângulo entre o eixo transpterigomaxilar e o eixo transcondilar (ETPTM.ETC).

65 Ângulo entre o eixo transpterigomaxilar e o eixo transespinhosos (ETPTM.ETE).

66 Ângulo entre o eixo transmolar inferior e o eixo transespinhosos (ETM.ETE).

67 Ângulo entre o eixo transmolar inferior e o eixo transcondilar (ETM.ETC).

68 Ângulo entre o eixo transmolar inferior e o eixo transpterigomaxilar (ETMI.ETPTM).

69 Ângulo entre o eixo transmolar superior e o eixo transespinhosos (ETMS.ETE).

70 Ângulo entre o eixo transmolar superior e o eixo transcondilar (ETMS.ETC).

71 Ângulo entre o eixo transmolar superior e o eixo transpterigomaxilar (ETMS.ETPTM).

\subsubsection{6 - Variáveis Adicionais (Figura 4.12):}

72 Distância do ponto condilar médio direito à linha média mandibular (PCMDLMM).

73 Distância do ponto condilar médio esquerdo à linha média mandibular (PCMELMM).

74 Ponto condilar médio direito ao contorno médio da mandíbula direita (PCMDCMMD).

75 Ponto condilar médio esquerdo ao contorno médio da mandíbula esquerda (PCME-CMME).

76 Posição lateral do primeiro molar inferior direito (POSMD).

77 Posição lateral do primeiro molar inferior esquerdo (POSME). 
78 Posição lateral do primeiro molar superior direito (POSMSD).

79 Posição lateral do primeiro molar superior esquerdo (POSMSE).

\subsubsection{7 - Diferenças entre as medidas bilaterais}

\subsection{1 - Coordenadas Mandibulares}

\subsection{1 - Ântero-posterior:}

80 Diferença de GO ao ETC (1-2).

81 Diferença de PPC ao ETC (3-4).

82 Diferença de PDMI ao ETC (5-6).

83 Diferença PDMS ao ETC (7-8).

\subsection{2 - Transverso:}

84 Diferença de GO ao EIC (9-10).

85 Diferença de PPC ao EIC (11-12).

86 Diferença de PDMI ao EIC (13-14).

87 Diferença PDMS ao EIC (15-16).

\subsection{2 - Coordenadas do Assoalho Craniano}

\subsection{1 - Ântero-posterior:}

88 Diferença de PCM ao ETE (20-21).

89 Diferença de GO ao ETE (22-23).

90 Diferença de PPC ao ETE (24-25).

91 Diferença de PDMI ao ETE (26-27).

92 Diferença PDMS ao ETE (28-29).

\subsection{2 - Transverso:}

93 Diferença de PCM ao EIE (30-31).

94 Diferença de GO ao EIE (32-33).

95 Diferença de PPC ao EIE (34-35).

96 Diferença de PDMI ao EIE (36-37).

97 Diferença PDMS ao EIE (38-39). 


\subsection{3 - Complexo Zigomaticomaxilar}

\subsection{1 - Ântero-posterior:}

98 Diferença de PDMI ao ETPTM (43-44).

99 Diferença de PDMS ao ETPTM (45-46).

\subsection{2 - Transverso:}

100 Diferença de PDMI ao EIPTM (49-50).

101 Diferença de PDMS ao EIPTM (51-52).

\subsection{4 - Variáveis Adicionais:}

102 Diferença entre PCM-LMM (72-73).

103 Diferença entre PCM-CMM (74-75).

104 Diferença de POSM (76-77).

105 Diferença de POSMS (78-79). 


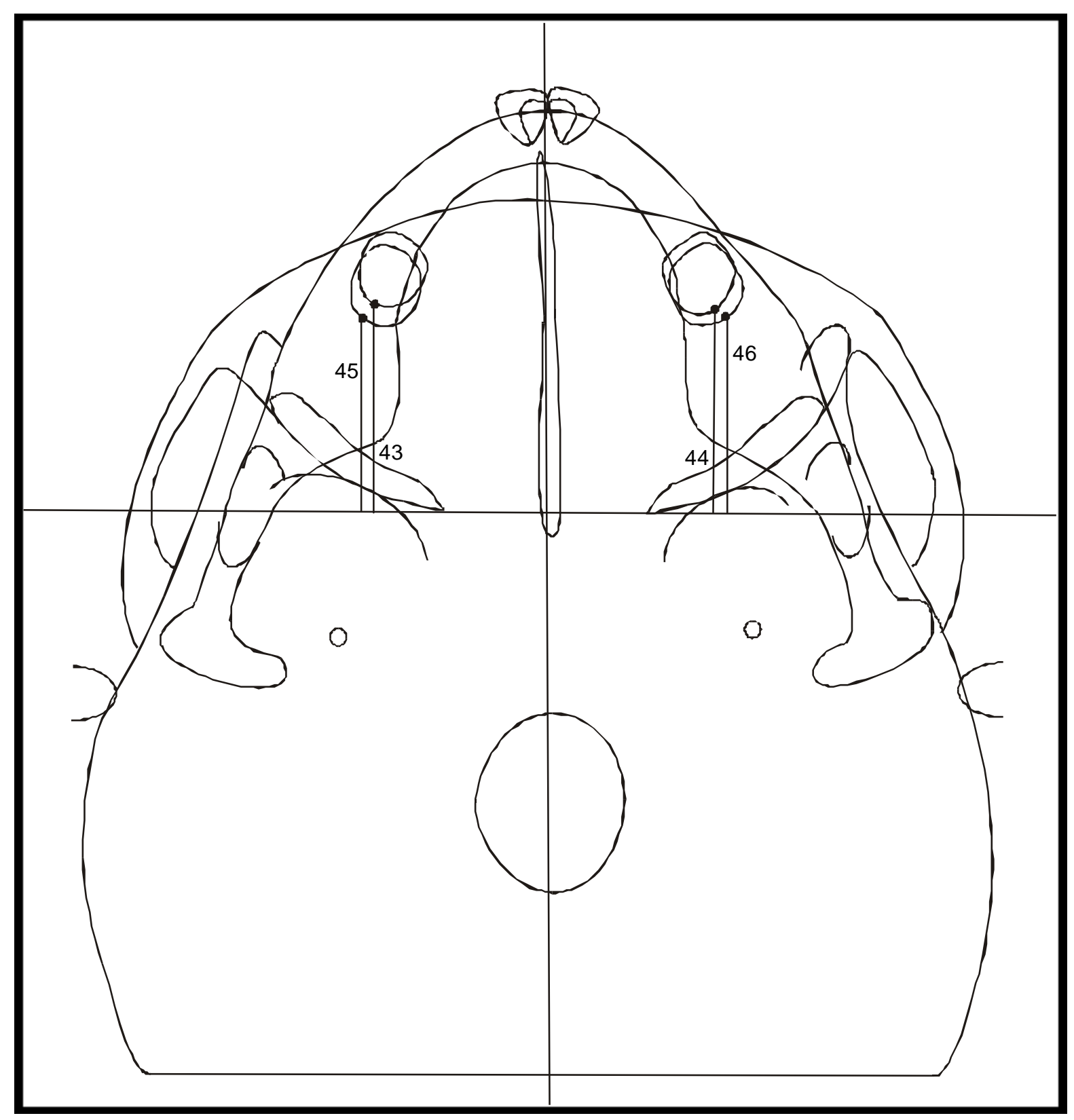

FIGURA 4.8 - Grandezas Cefalométricas da Radiografia Submentoniana*

Sistema de Coordenadas do Complexo Zigomaticomaxilar - Ântero-Posterior

\footnotetext{
* FONTE: Figura reproduzida da pesquisa de JANSON ${ }^{73}$.
} 


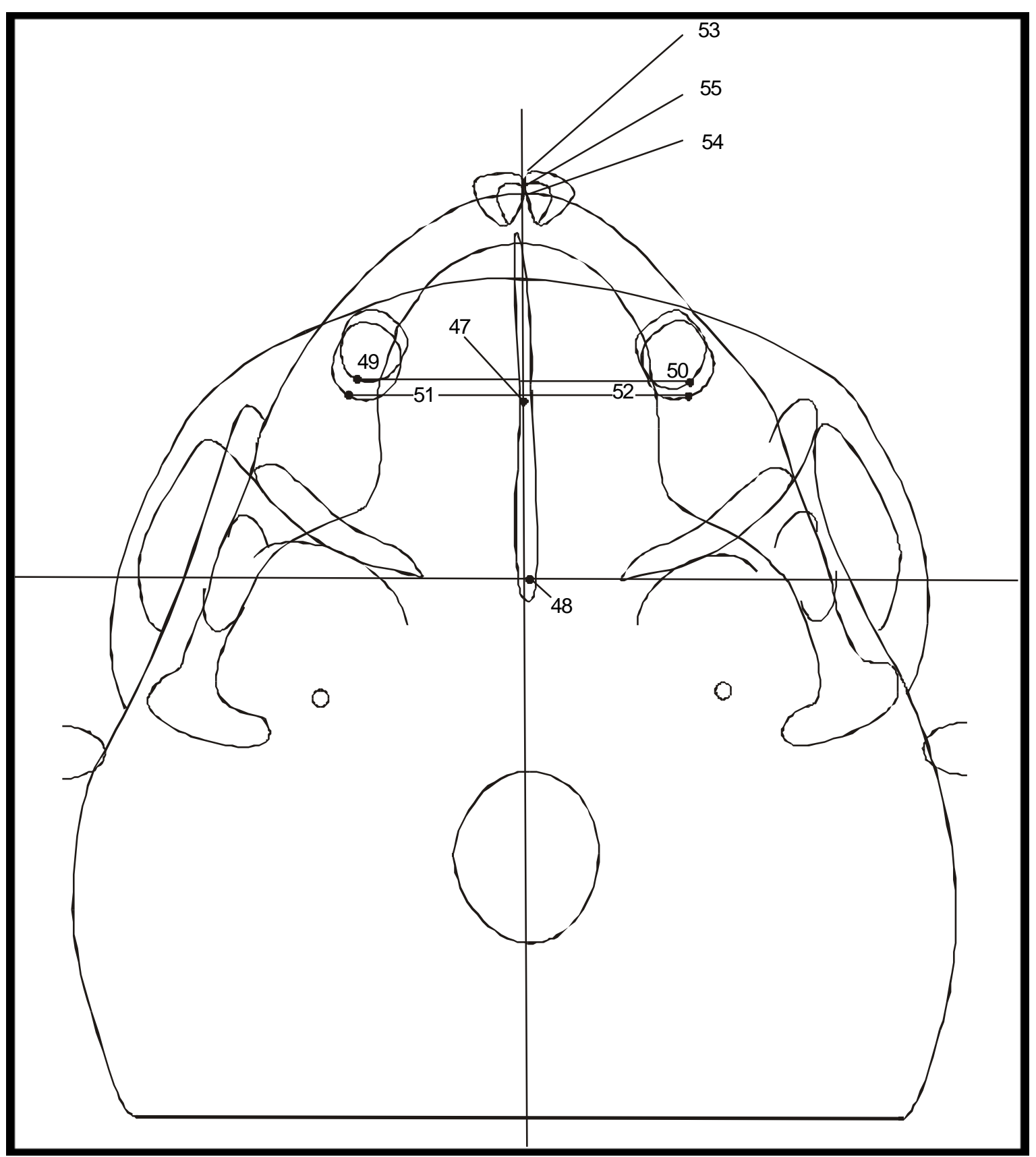

FIGURA 4.9 - Grandezas Cefalométricas da Radiografia Submentoniana* Sistema de Coordenadas do Complexo Zigomaticomaxilar - Transverso

\footnotetext{
* FONTE: Figura reproduzida da pesquisa de JANSON ${ }^{73}$.
} 


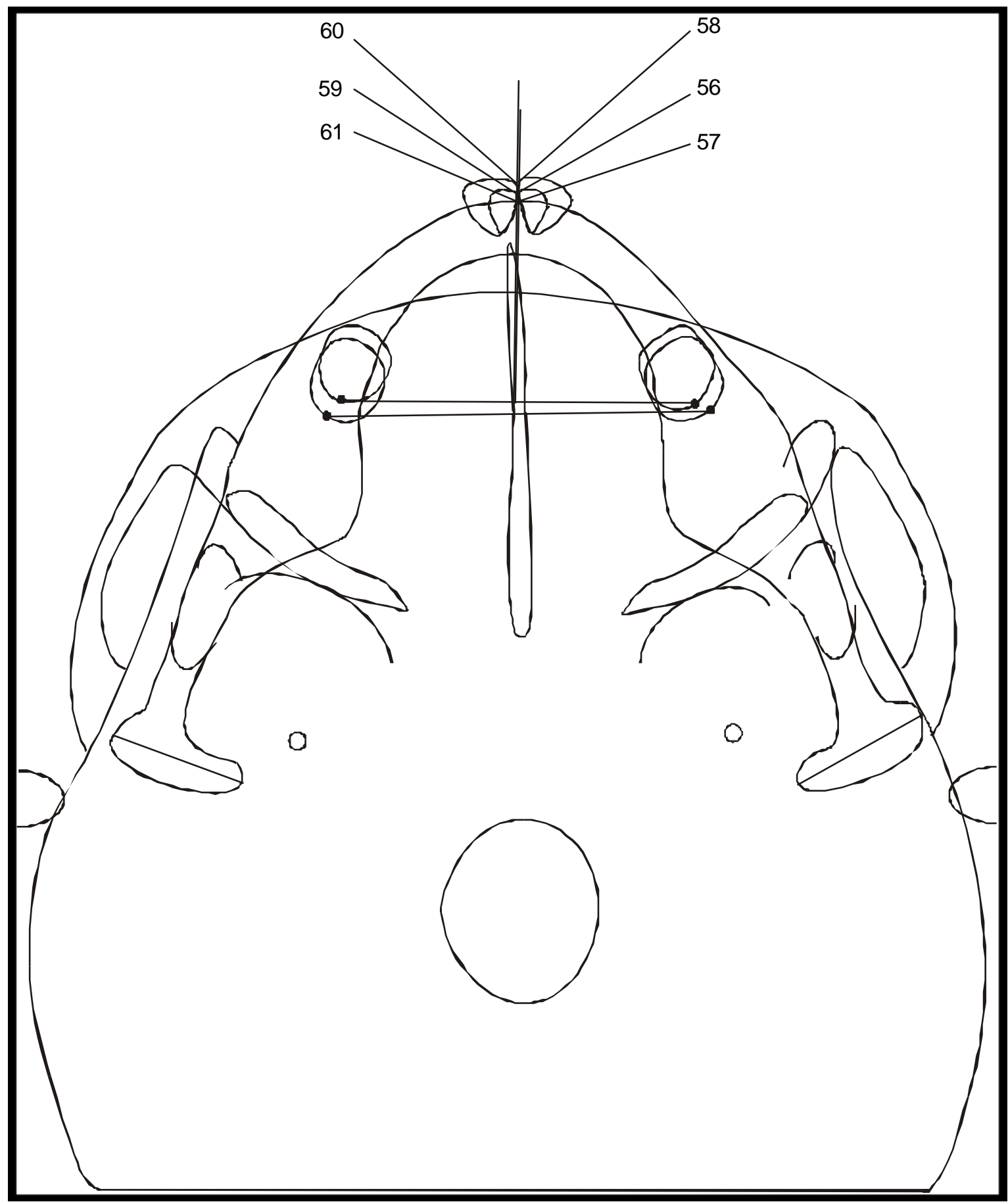

FIGURA 4.10 - Grandezas Cefalométricas da Radiografia Submentoniana* Sistema de Coordenadas Dentárias - Transverso

\footnotetext{
* FONTE: Figura reproduzida da pesquisa de $\mathrm{JANSON}^{73}$.
} 


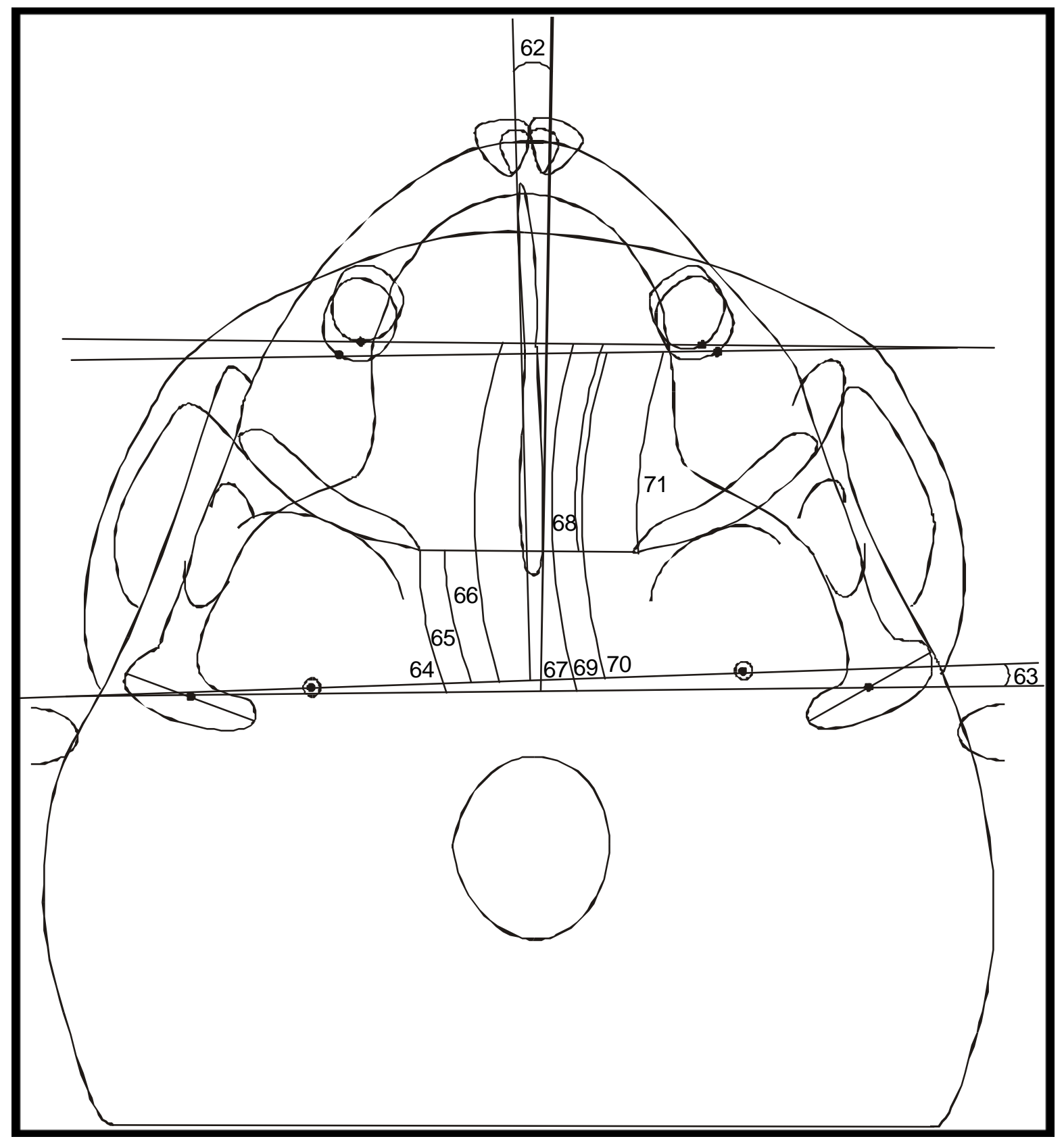

FIGURA 4.11 - Grandezas Cefalométricas da Radiografia Submentoniana* Medidas Angulares entre as Abscissas dos Sistemas de Coordenadas

\footnotetext{
* FONTE: Figura reproduzida da pesquisa de $\mathrm{JANSON}^{73}$.
} 


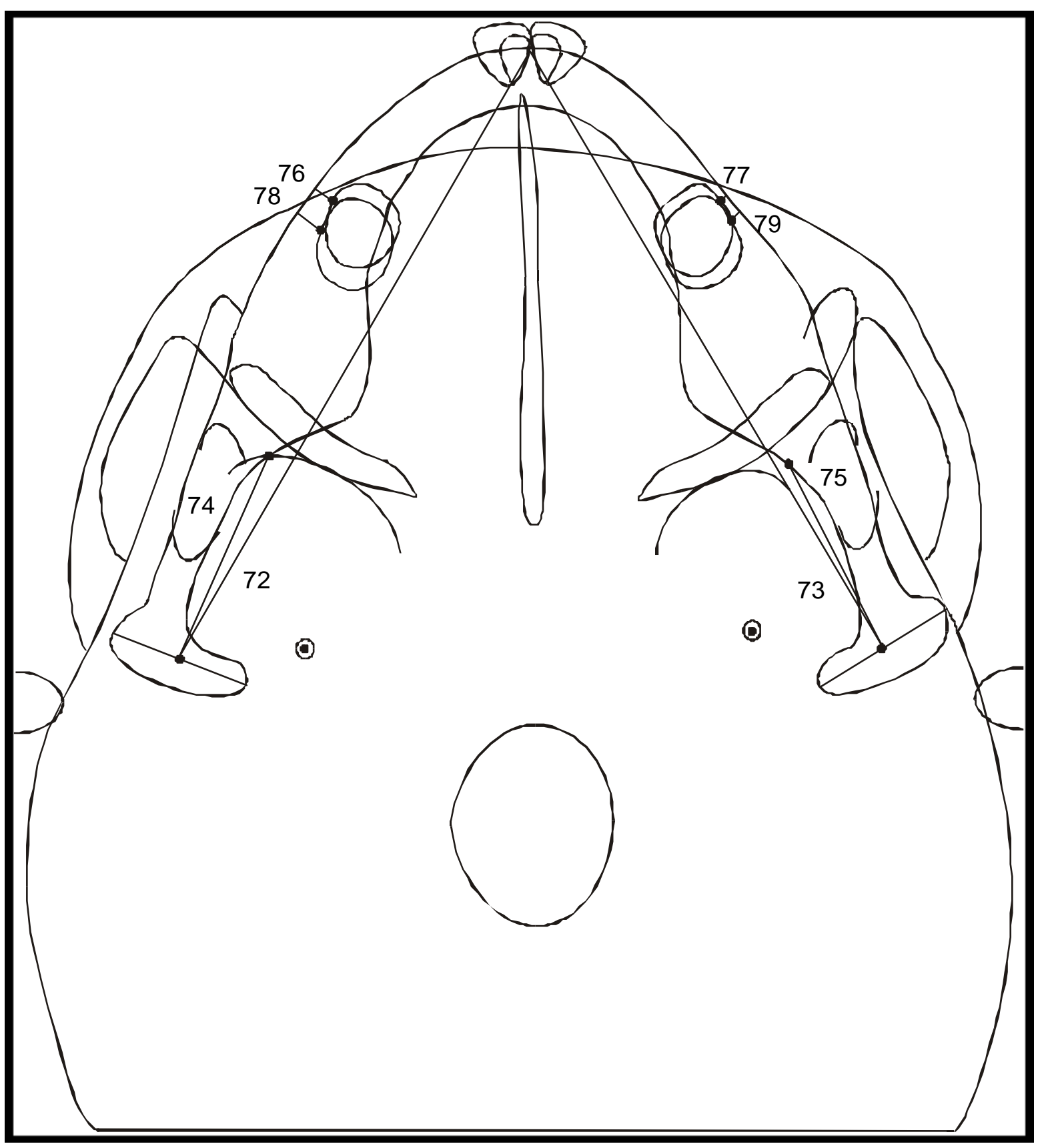

FIGURA 4.12 - Grandezas Cefalométricas da Radiografia Submentoniana* Variáveis Adicionais

\footnotetext{
* FONTE: Figura reproduzida da pesquisa de JANSON ${ }^{73}$.
} 


\subsection{2 - Radiografias Póstero-Anteriores (PA)}

As radiografias póstero-anteriores foram obtidas utilizando-se a seguinte técnica: cada indivíduo foi posicionado no cefalostato, com a testa e o nariz tocando levemente o chassis ${ }^{58}$. O aparelho utilizado para essas radiografias foi o ROENTAX $10090^{d}$, com filme Kodak X-Omat $K$ (não interfoliado) e tempo de exposição de 1s, a $90 \mathrm{kVp}$ e 25ma. A distância do ponto focal até as olivas metálicas foi padronizada em $152 \mathrm{~cm}$ e a distância das olivas metálicas até o filme foi fixada em $16 \mathrm{~cm}$, o que fornecia um fator de magnificação de 8,91\%. Durante a tomada das radiografias, os pacientes mantiveram os dentes em máxima intercuspidação habitual.

A delimitação das estruturas anatômicas, a demarcação dos pontos e linhas e a obtenção das grandezas cefalométricas foram realizadas nas radiografias, de acordo com GRUMMONS; VAN DE COPPELLO ${ }^{55}$.

\subsubsection{1 - Estruturas Anatômicas (Figura 4.13):}

Para as estruturas bilaterais os números referem-se às estruturas enumeradas e às suas homólogas, do lado oposto.

1 Órbitas

2 Contornos da cavidade nasal

3 Crista galli

4 Arcos zigomáticos

5 Contorno mandibular de um côndilo a outro

6 Contornos maxilares direito e esquerdo

7 Aspectos laterais do osso frontal

8 Aspectos laterais dos ossos zigomáticos

9 Incisivos centrais superiores

10 Incisivos centrais inferiores

11 Primeiros molares superiores

12 Primeiros molares inferiores

\footnotetext{
${ }^{d}$ EMIC (Eletro Medicina Indústria e Comércio LTDA - R. Paulo Franco, 195, São Paulo - SP - Brasil - Fone: 11 - 8321131 )
} 


\subsubsection{2 - Pontos de Referência (Figura 4.14):}

1 Ponto mais superior no contorno da margem da órbita direita, localizado à meia distância, entre as margens média e lateral.

2 Ponto localizado na borda lateral da órbita direita, na porção interna da sutura frontozigomática.

3 Ponto mais inferior do contorno da órbita direita, localizado aproximadamente à meia distância, entre as margens média e lateral.

4 Ponto mais medial do contorno da órbita direita, localizado aproximadamente à meia distância, entre as margens superior e inferior.

5 Ponto mais superior do contorno da órbita esquerda, localizado aproximadamente à meia distância, entre as margens média e lateral.

6 Ponto mais medial do contorno da órbita esquerda, localizado aproximadamente à meia distância, entre as margens superior e inferior.

7 Ponto mais inferior do contorno da órbita esquerda, localizado aproximadamente à meia distância, entre as margens medial e lateral.

8 Ponto localizado na borda lateral da órbita esquerda, na porção interna da sutura frontozigomática.

9 Ponto mais superior do contorno do orifício nasal.

10 Ponto mais lateral do contorno do orifício nasal, na região da abertura piriforme direita.

11 Ponto localizado na intersecção do septo nasal com o assoalho do nariz.

12 Ponto mais lateral do contorno do orifício nasal, na região da abertura piriforme esquerda.

13 Ponto de referência látero-superior direito: ponto localizado na porção lateral da sutura frontozigomática direita, ou na intersecção da asa maior direita do esfenóide e da margem orbitária.

14 Ponto na margem lateral do arco zigomático direito, centrado verticalmente.

15 Ponto localizado na profundidade da concavidade do contorno lateral do maxilar direito, na junção da maxila e do osso zigomático.

16 Ponto de referência látero-superior esquerdo: ponto localizado na porção lateral da sutura frontozigomática esquerda, ou na intersecção da asa maior esquerda do esfenóide e da margem orbitária. 
17 Ponto na margem lateral do arco zigomático esquerdo, centrado verticalmente.

18 Ponto localizado na profundidade da concavidade do contorno lateral do maxilar esquerdo, na junção da maxila e do osso zigomático.

19 Ponto localizado numa perpendicular à superfície oclusal do primeiro molar superior direito, através da cúspide vestibular, na altura da raiz vestibular (verticalmente).

20 Ponta de cúspide vestibular do primeiro molar superior direito.

21 Ápice radicular do incisivo central superior direito.

22 Ponto localizado no meio da borda incisal do incisivo central superior direito.

23 Ponto localizado apicalmente entre as raízes dos incisivos centrais superiores, distante aproximadamente $2 / 3$ do comprimento radicular ${ }^{25}$.

24 Ápice radicular do incisivo central superior esquerdo.

25 Ponto localizado no meio da borda incisal do incisivo central superior esquerdo.

26 Ponto localizado numa perpendicular à superfície oclusal do primeiro molar superior esquerdo, através da cúspide vestibular, na altura da raiz vestibular.

27 Ponta de cúspide vestibular do primeiro mola r superior esquerdo.

28 Ponta de cúspide vestibular do primeiro molar inferior direito.

29 Ponto localizado no ápice radicular, através de uma perpendicular traçada à superfície oclusal do primeiro molar inferior direito, a partir da cúspide vestibular.

30 Ponto centrado na borda incisal do incisivo central inferior direito.

31 Ápice radicular do incisivo central inferior direito.

32 Ponto localizado apicalmente entre as raízes dos incisivos centrais inferiores, distante aproximadamente $2 / 3$ do comprimento radicular ${ }^{25}$.

33 Ponto centrado na borda incisal do incisivo central inferior esquerdo.

34 Ápice radicular do incisivo central inferior esquerdo.

35 Ponta de cúspide vestibular do primeiro molar inferior esquerdo.

36 Ponto localizado no ápice radicular do primeiro molar inferior esquerdo, através de uma perpendicular traçada na sua superfície oclusal, a partir da cúspide vestibular. 
37 Ponto centrado na superfície superior da cabeça do côndilo direito.

38 Ponto localizado na borda lateral da cabeça do côndilo direito.

39 Ponto localizado na borda lateral do ramo mandibular direito, localizado aproximadamente à meia distância, entre a cabeça do côndilo e o ângulo goníaco.

40 Ponto localizado na junção da borda lateral do ramo mandibular direito com o início da convexidade do ângulo goníaco direito.

41 Ponto localizado no ângulo goníaco direito da mandíbula.

42 Ponto localizado na chanfradura antegoniana direita.

43 Ponto localizado na superfície inferior do corpo mandibular direito, entre o ângulo goníaco e a sínfise.

44 Ponto localizado na superfície inferior do corpo mandibular direito, representando o limite lateral direito da concavidade da sínfise (se existir).

45 Ponto mentoniano que consiste no ponto mais inferior na borda da mandíbula, na sínfise.

46 Ponto localizado na superfície inferior do corpo mandibular esquerdo, representando o limite lateral esquerdo da concavidade da sínfise (se existir).

47 Ponto na superfície inferior do corpo mandibular esquerdo, à meia distância entre o ângulo goníaco e a sínfise.

48 Ponto localizado na chanfradura antegoniana esquerda.

49 Ponto localizado no ângulo goníaco esquerdo da mandíbula.

50 Ponto localizado na junção da borda lateral do ramo mandibular esquerdo, com o início da convexidade do ângulo goníaco esquerdo.

51 Ponto na borda lateral do ramo mandibular esquerdo, aproximadamente à meia distância entre a cabeça do côndilo e o ângulo goníaco.

52 Ponto localizado na borda lateral da cabeça do côndilo esquerdo.

53 Ponto centrado na superfície superior da cabeça do côndilo esquerdo.

54 Ponto mais superior da crista galli, idealmente no meio do osso.

55 Espinha nasal anterior.

56 Ponto médio de intercuspidação das pontas de cúspides dos primeiros molares superior e inferior, do lado direito (construído). 
57 Ponto médio de intercuspidação das pontas de cúspides dos primeiros molares superior e inferior, do lado esquerdo (construído).

58 Ponto médio entre os incisivos superiores (construído).

59 Ponto médio entre os incisivos inferiores (construído).

\subsubsection{3 - Linhas e Planos (Figura 4.15):}

A Plano Z (linha) - formado pela conexão dos pontos 2 e 8.

B Linha- $X^{57}$ - linha perpendicular ao plano Z, passando pela crista galli.

C Plano oclusal - plano formado entre os pontos médios de intercuspidação das pontas de cúspides dos primeiros molares superior e inferior, de cada lado, respectivamente (pontos 56 e 57, construídos)

D Plano antegoniano - plano formado entre os pontos 42 e 48 (chanfradura antegoniana).

E Linha do ramo mandibular direito (formada pelos pontos 37 e 42)

F $\quad$ Linha do ramo mandibular esquerdo (formada pelos pontos 53 e 48)

G Linha do corpo mandibular direito (formada pelos pontos 42 e 45)

$\mathrm{H} \quad$ Linha do corpo mandibular esquerdo (formada pelos pontos 45 e 48)

\subsubsection{4 - Grandezas Cefalométricas (Figuras 4.16 e 4.17):}

Para a obtenção das medidas lineares bilaterais ou das estruturas não pareadas, a medição foi realizada da estrutura em questão até a linha de referência vertical média (Linha-X), paralelamente ao Plano Z.

1 Ângulo do plano Z (ÂPLANOZ) - Ângulo entre o plano Z (8 e 2) e a linha Cg (Crista galli) - ENA (54 e 55) (Fig. 4.16). 
2 Ângulo do plano oclusal (ÂPLOCLUSAL) - Ângulo entre o plano oclusal (pontos nํs 56 e 57, construídos) e a linha Cg (Crista galli) - ENA (54 e 55) (Fig 4.16).

3 Ângulo do plano antegoniano (ÂPLANTEG) - Ângulo entre 0 plano antegoniano (pontos nos 42 e 48) e a linha Cg (Crista galli) - ENA (54 e 55) (Fig 4.16).

4 Desvio da espinha nasal anterior (DESVENA) - Distância (ponto-linha) entre a espinha nasal anterior (55) e a Linha-X (Fig 4.17).

5 Desvio mandibular (DESMAND) - Distância (ponto-linha) entre o mentoniano (45) e a Linha-X (Fig 4.17).

6 Desvio da linha média superior (A1) - Distância (ponto-linha) entre a linha média dos incisivos superiores (58) e a Linha-X (Fig 4.17).

7 Desvio da linha média inferior (B1) - Distância (ponto-linha) entre a linha média dos incisivos inferiores (59) e a Linha-X (Fig 4.17).

8 Ângulo antegoniano direito (ÂANTD) - Ângulo entre o ramo mandibular (37 e 42) e o corpo mandibular direito (42 e 45) (Fig 4.16).

9 Ângulo antegoniano esquerdo (ÂANTE) - Ângulo entre o ramo mandibular (48 e 53) e o corpo mandibular esquerdo (45 e 48) (Fig 4.16).

10 Distância Z direita (DISTZD) - Distância horizontal entre a sutura frontozigomática (ponto Z) direita (2) e a Linha-X (Fig 4.17).

11 Distância Z esquerda (DISTZE) - Distância horizontal entre a sutura frontozigomática (ponto Z) esquerda (8) e a Linha-X (Fig 4.17).

12 Distância CO direita (DISTCOD) - Distância horizontal entre o condílio direito (37) e a Linha-X (Fig 4.17).

13 Distância CO esquerda (DISTCOE) - Distância horizontal entre o condílio esquerdo (53) e a Linha-X (Fig 4.17).

14 Distância ZA direita (DISTZAD) - Distância horizontal entre o zygoma direito (14) e a Linha-X (Fig 4.17).

15 Distância ZA esquerda (DISTZAE) - Distância horizontal entre o zygoma esquerdo (17) e a Linha-X (Fig 4.17).

16 Distância NC direita (DISTNCD) - Distância horizontal entre a parede lateral da abertura piriforme direita (10) e a Linha-X (Fig 4.17). 
17 Distância NC esquerda (DISTNCE) - Distância horizontal entre a parede lateral da abertura piriforme esquerda (12) e a Linha-X (Fig 4.17).

18 Distância J direita (DISTJD) - Distância horizontal entre o processo jugal direito da maxila (15) e a Linha-X (Fig 4.17).

19 Distância J esquerda (DISTJE) - Distância horizontal entre o processo jugal esquerdo da maxila (18) e a Linha-X (Fig 4.17).

20 Distância AG direita (DISTAGD) - Distância horizontal entre a chanfradura antegoniana direita (42) e a Linha-X (Fig 4.17).

21 Distância AG esquerda (DISTAGE) - Distância horizontal entre a chanfradura antegoniana esquerda (48) e a Linha-X (Fig 4.17).

22 Altura do primeiro molar superior direito (ALTㅌD) - Distância vertical entre o processo jugal direito (15) e a ponta de cúspide vestibular do primeiro molar superior direito (20) (Fig 4.17).

23 Altura do primeiro molar superior esquerdo (ALTㅌE) - Distância vertical entre o processo jugal esquerdo (18) e a ponta de cúspide vestibular do primeiro molar superior esquerdo (20) (Fig 4.17).

24 Distância CO-AG Direita (CO-AGD) - Tamanho do ramo mandibular direito, do condílio (37) até a chanfradura antegoniana (42) (Fig 4.17).

25 Distância CO-AG Esquerda (CO-AGE) - Tamanho do ramo mandibular esquerdo, do condílio (53) até a chanfradura antegoniana (48) (Fig 4.17).

26 Distância CO-ME Direita (CO-MED) - Tamanho do lado direito da mandíbula, do condílio (37) até o mentoniano (45) (Fig 4.17).

27 Distância CO-ME Esquerda (CO-MEE) - Tamanho do lado esquerdo da mandíbula, do condílio (53) até o mentoniano (45) (Fig 4.17).

28 Distância ME-AG Direita (ME-AGD) - Tamanho do corpo mandibular direito, da chanfradura antegoniana (42) até o mentoniano (45) (Fig 4.17).

29 Distância ME-AG Esquerda (ME-AGE) - Tamanho do corpo mandibular esquerdo, da chanfradura antegoniana (48) até o mentoniano (45) (Fig 4.17). 


\subsubsection{1 - Diferenças entre as medidas bilaterais:}

As diferenças entre as medidas bilaterais consistiram na assimetria dos casos avaliados.

30 Diferença ângulo antegoniano - ÂANT - (8-9).

31 Diferença distância Z - DISTZ - (10-11).

32 Diferença distância CO - DISTCO - (12-13).

33 Diferença distância ZA - DISTZA - (14-15).

34 Diferença distância NC - DISTNC - (16-17).

35 Diferença distância J - DISTJ - (18-19).

36 Diferença distância AG - DISTAG - (20-21).

37 Diferença altura do primeiro molar superior A6 - ALT6 - (22-23).

38 Diferença distância CO-AG - CO-AG - (24-25).

39 Diferença distância CO-ME - CO-ME - (26-27).

40 Diferença distância ME-AG - ME-AG - (28-29). 


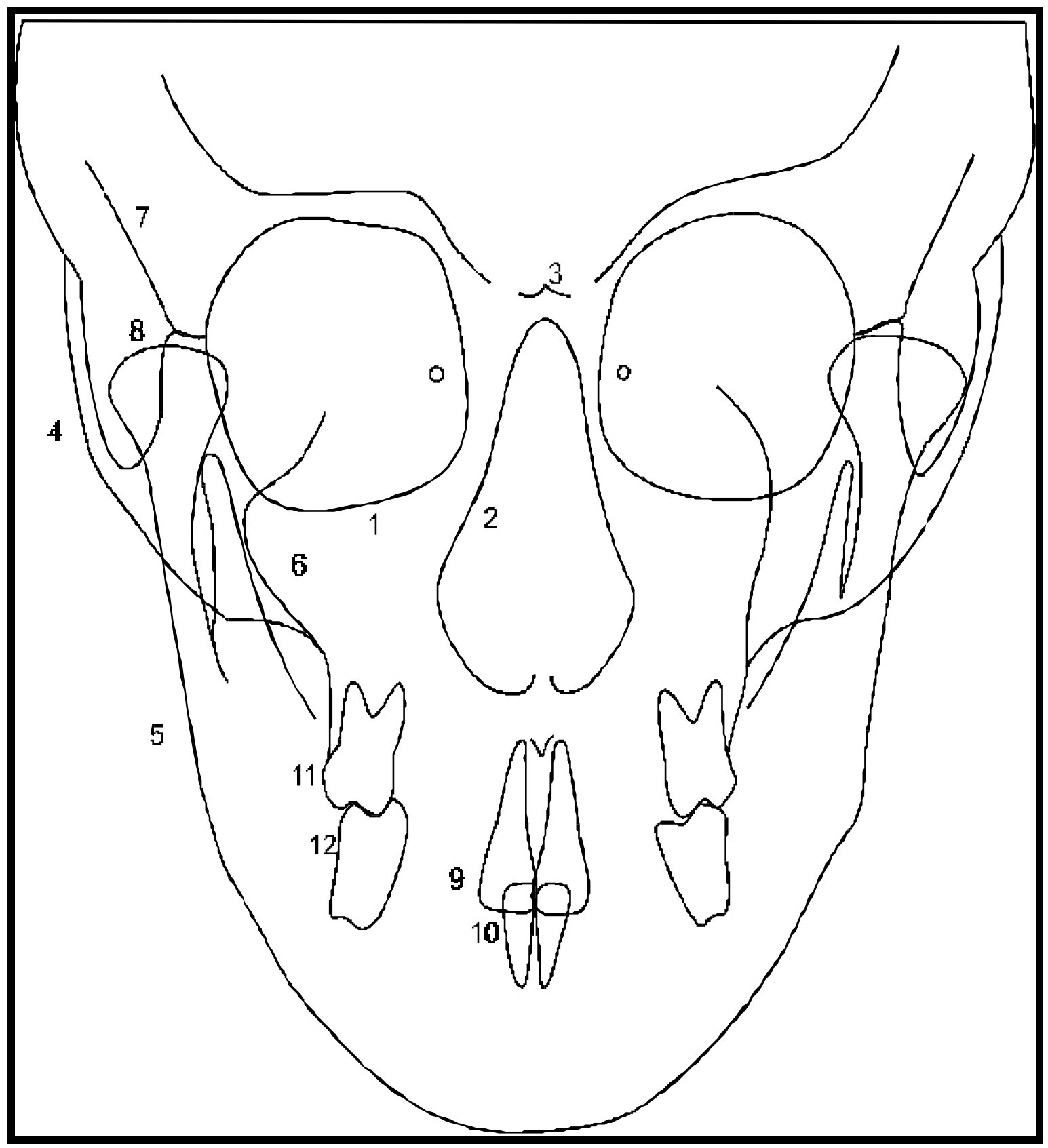

FIGURA 4.13 - Estruturas Anatômicas da Radiografia Póstero-Anterior*

\footnotetext{
* FONTE: Figura reproduzida da pesquisa de JANSON ${ }^{73}$.
} 


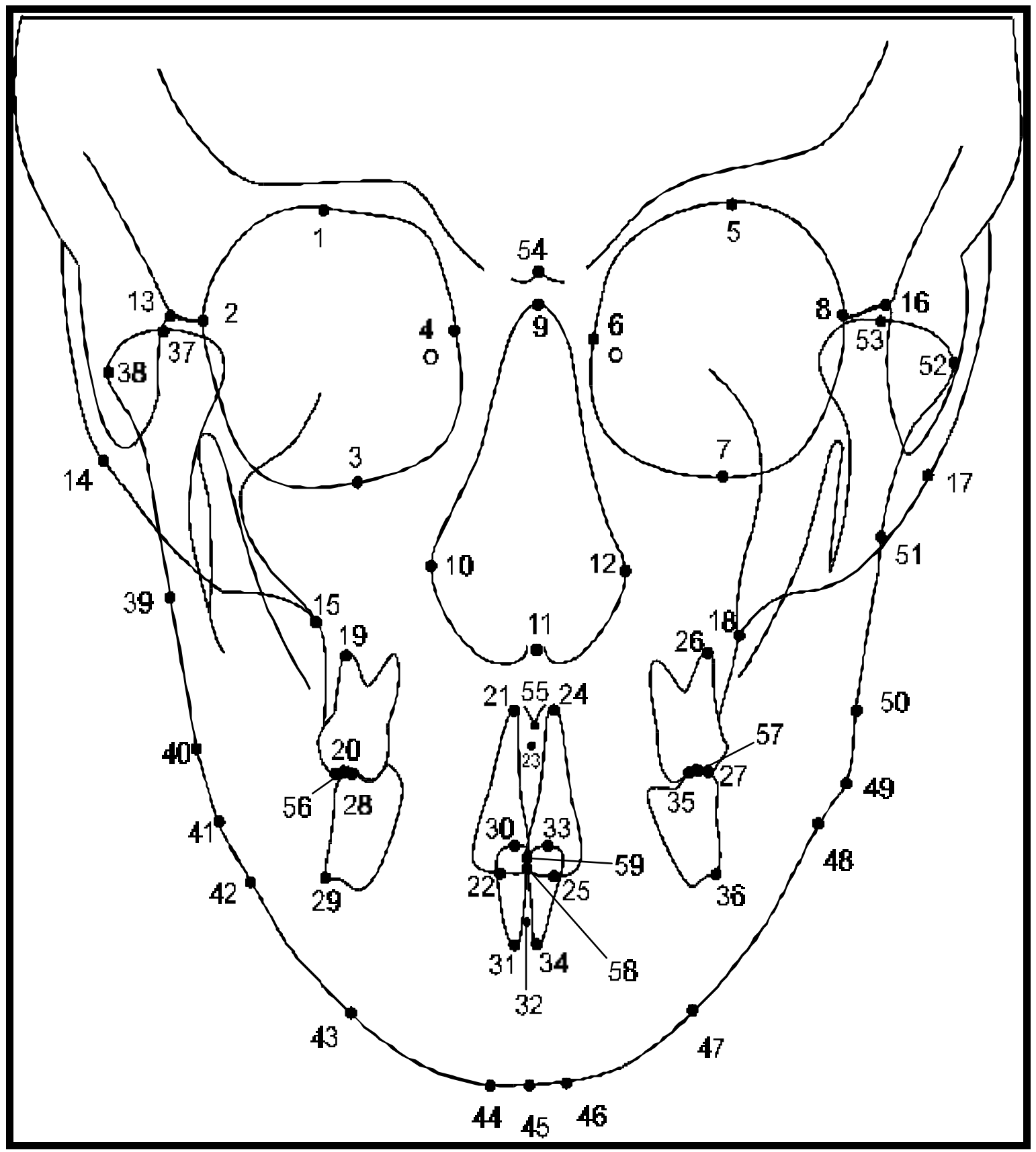

FIGURA 4.14 - Pontos de Referência da Radiografia Póstero-Anterior*

\footnotetext{
* FONTE: Figura reproduzida da pesquisa de $\mathrm{JANSON}^{73}$.
} 


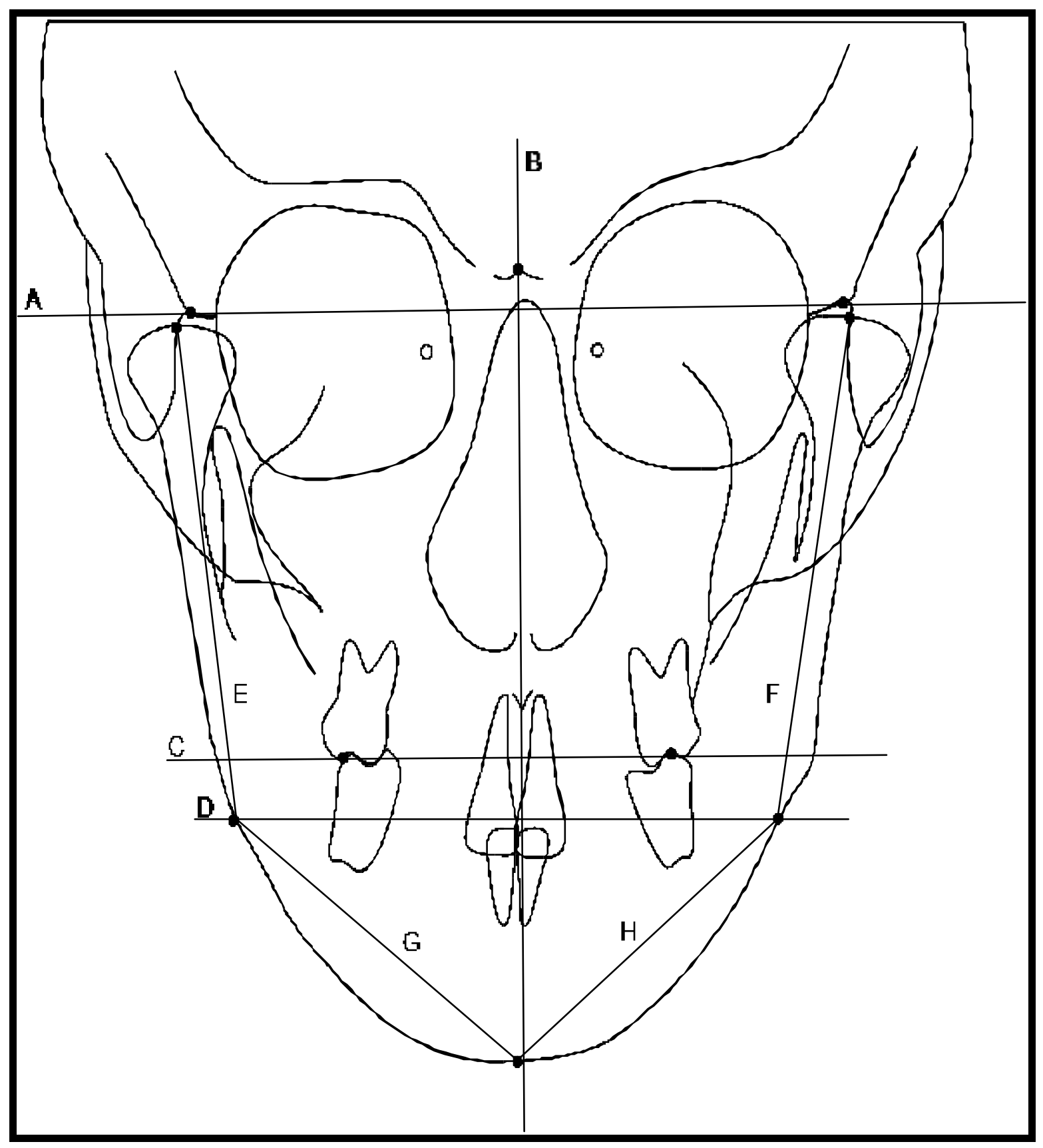

FIGURA 4.15 - Linhas e Planos da Radiografia Póstero-Anterior*

\footnotetext{
* FONTE: Figura reproduzida da pesquisa de JANSON ${ }^{73}$.
} 


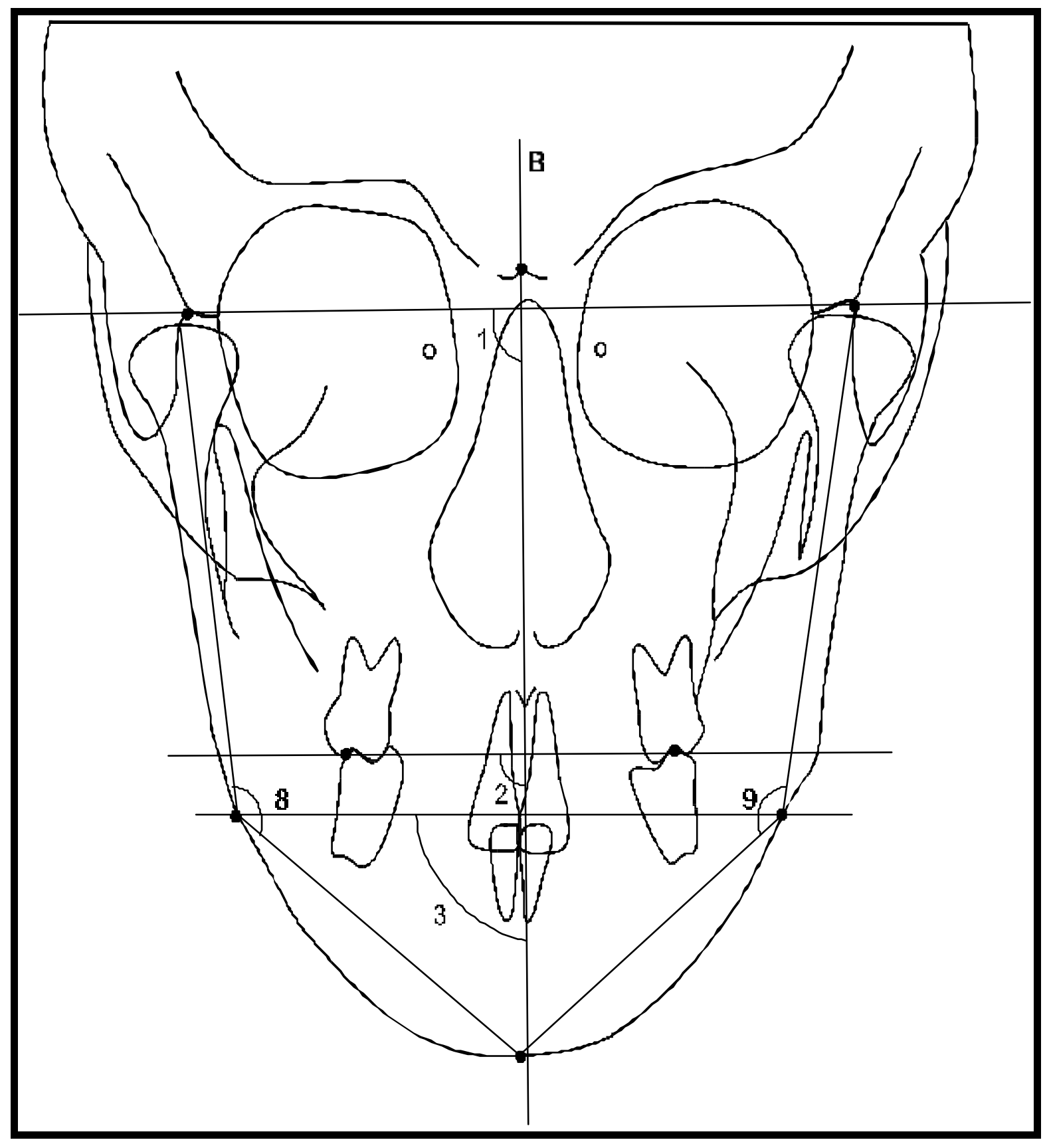

FIGURA 4.16 - Grandezas Angulares da Radiografia Póstero-Anterior*

\footnotetext{
${ }^{*}$ FONTE: Figura reproduzida da pesquisa de JANSON ${ }^{73}$.
} 


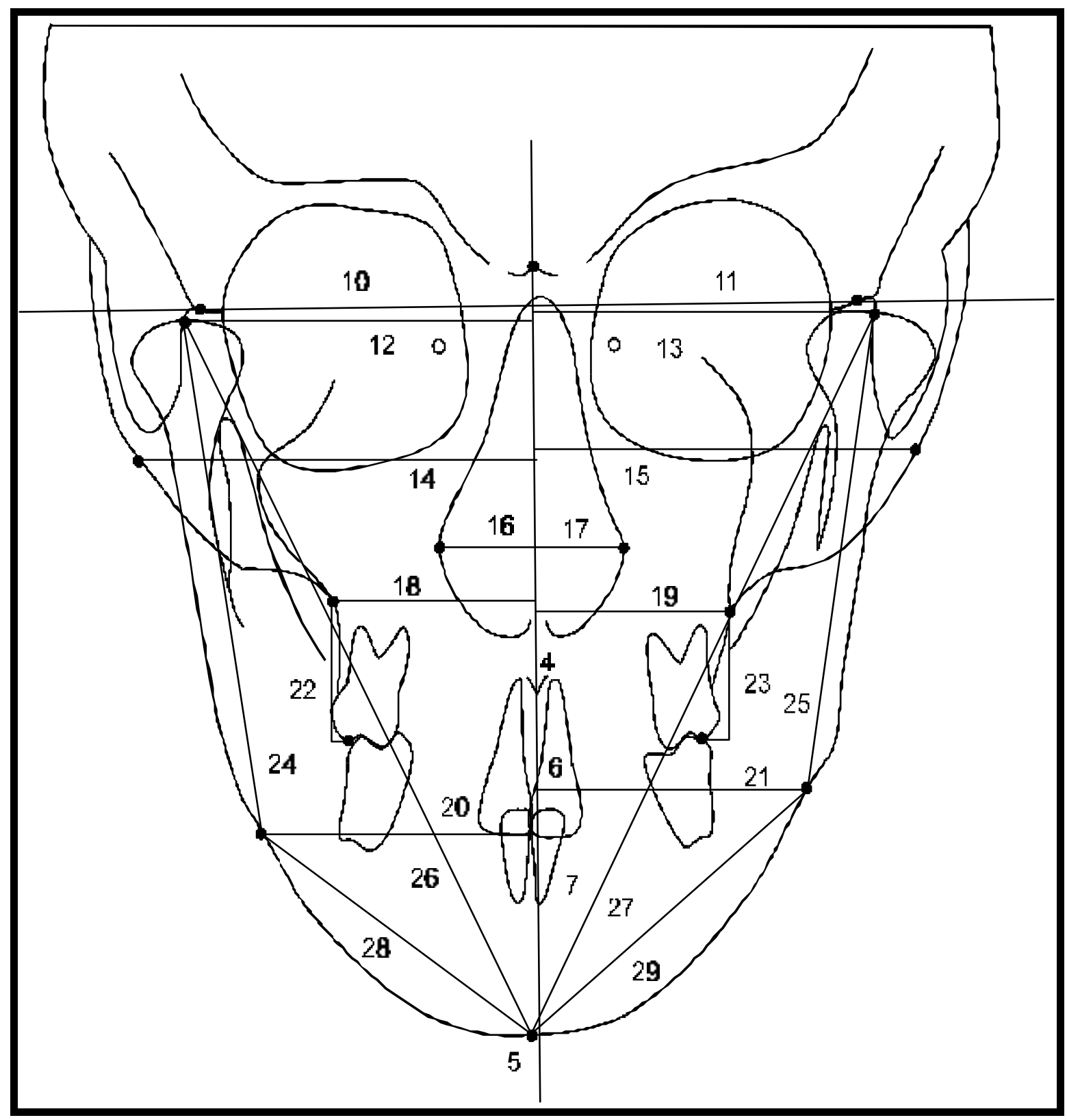

FIGURA 4.17 - Grandezas Lineares da Radiografia Póstero-Anterior

\footnotetext{
${ }^{*}$ FONTE: Figura reproduzida da pesquisa de JANSON ${ }^{73}$.
} 


\subsection{3 - Análise Estatística}

\subsubsection{1 - Erro do Método}

Para a avaliação do erro intra-examinador, foram traçadas, redigitalizadas e medidas novamente as radiografias submentoniana e póstero-anterior de dez pacientes do grupo de Classe II, subdivisão tratado, selecionados aleatoriamente, somando-se ao total, 20 radiografias. A aplicação da fórmula proposta por DAHLBERG $^{37}\left(\mathrm{Se}^{2}=\right.$ somatória ơ $\left./ 2 \mathrm{n}\right)$ permitiu estimar a ordem de grandeza dos erros casuais. A obtenção dos erros sistemáticos procedeurse pela aplicação do teste $t$ pareado de acordo com BAUMRIND; FRANTZ ${ }^{9}$ (1971), GRAVELY; BENZIES $^{52}$ (1974), HOUSTON ${ }^{66}$ (1983), RICHARDSON ${ }^{135}$ (1966), tabelas 8 a 14.

\subsubsection{2 - Comparações entre os Grupos ${ }^{176}$}

O teste t para variáveis independentes foi utilizado na comparação entre os dois grupos experimentais (grupos 1 e 2) com o grupo de oclusão normal (grupo 3) quanto às assimetrias entre os dois lados, nas duas radiografias, em tempos diferentes (tabelas 15 a 28 - capítulo de Resultados). Para a utilização do teste t, tornou-se necessária a distribuição normal das variáveis, que foi avaliada pelo teste de Kolmogorov-Smirnov, para cada uma das variáveis. Os resultados foram considerados estatisticamente significantes para $p<0,05$.

Como o grupo de Classe II, subdivisão tratado era constituído de 17 casos com extração de um pré-molar superior e de 13 casos com extrações de dois prémolares superiores e um pré-molar inferior, decidiu-se investigar, separadamente, qual a influência destes diferentes protocolos de extrações, no resultado final, em relação às características de oclusão normal. Portanto, subdividiu-se o grupo de Classe II, subdivisão tratado em dois subgrupos: o subgrupo A, composto de 17 pacientes tratados com extrações de apenas um pré-molar superior do lado da Classe II e o subgrupo $B$, constituído de 13 pacientes tratados com extrações de três pré-molares, sendo dois pré-molares superiores e um pré-molar inferior do lado da 
Classe I. Posteriormente, estes subgrupos foram comparados por meio de um teste t independente com o grupo 3, de oclusão normal, em tempos diferentes.

Todas estas análises foram realizadas com o programa Statistica ${ }^{e}$.

Considerou-se que o grupo 2 ou os subgrupos A e B tinham apresentado uma melhora se as variáveis do grupo 1, que tiveram uma diferença estatisticamente significante com o grupo 3, não fossem estatisticamente diferentes do grupo com oclusão normal.

$\overline{{ }^{e} \text { Statistica for Windows - Release 4.3B. }}$ - Copywright Statsoft, Inc. 1993. 


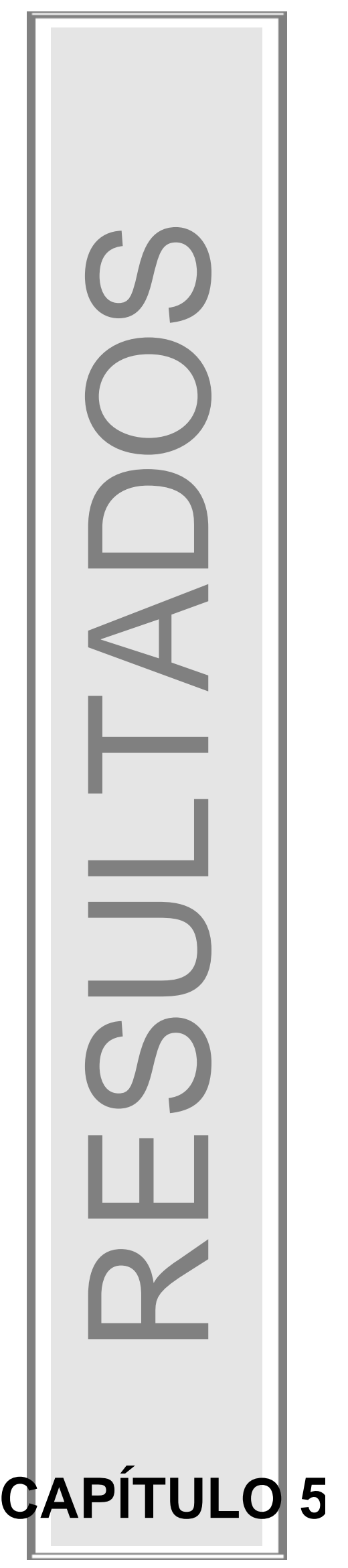




\section{5 - RESULTADOS}

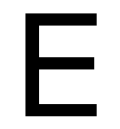

ste capítulo apresenta as avaliações estatísticas básicas. As tabelas de 1

a 7, referem-se às médias reais e aos desvios padrão das variáveis pesquisadas e nas tabelas 8 a 14 estão dispostos os valores dos erros casuais e sistemáticos. As tabelas 15 a 21 representam os resultados do teste t independente da comparação dos grupos de oclusão normal e de Classe II, subdivisão, não tratado ${ }^{73}$. As tabelas 22 a 28 revelam os dados obtidos entre os grupos de oclusão normal e Classe II, subdivisão, tratado com extrações assimétricas. Para uma melhor análise dos resultados obtidos quanto aos diferentes protocolos de extrações assimétricas, as tabelas 29 a 35 apresentam os resultados do teste t independente da comparação entre os grupos de oclusão normal e de Classe II, subdivisão, tratado com extração de um pré-molar superior (subgrupo A). Finalmente, as de número 36 a 42 revelam os dados do teste $t$ independente da comparação entre os grupos de oclusão normal e de Classe II, subdivisão, tratado com extrações de três pré-molares (subgrupo B). Os resultados em vermelho denotam uma diferença estatisticamente significante $(p<0,05)$.

Os resultados do teste de Kolmogorov-Smirnov não foram estatisticamente significantes para todas as variáveis, demonstrando, portanto, que houve uma distribuição normal e o teste t pôde ser aplicado.

TABELAS de 1 a 7 - Médias reais e desvios padrão das variáveis pesquisadas RADIOGRAFIA SUBMENTONIANA

TABELA 1 - Sistema de Coordenadas Mandibulares

\begin{tabular}{|c|c|c|c|c|c|c|}
\hline \multicolumn{7}{|c|}{ ANTERO-POSTERIOR } \\
\hline \multirow[b]{2}{*}{ VARIÁVEIS } & Médias & D.P. & Médias & D.P. & Médias & D.P. \\
\hline & $\begin{array}{l}\text { Oclusão } \\
\text { Normal }\end{array}$ & $\begin{array}{l}\text { Oclusão } \\
\text { Normal }\end{array}$ & $\begin{array}{c}\text { Classe II, } \\
\text { sub. }\end{array}$ & $\begin{array}{c}\text { Classe II, } \\
\text { sub. }\end{array}$ & $\begin{array}{c}\text { Classe II, } \\
\text { sub. } \\
\text { tratado }\end{array}$ & $\begin{array}{c}\text { Classe II, } \\
\text { sub. } \\
\text { tratado }\end{array}$ \\
\hline GO-ETC & $-0,10$ & 1,73 & 0,46 & 1,60 & $-0,02$ & 1,71 \\
\hline PPC-ETC & $-0,30$ & 1,56 & 0,15 & 1,92 & 0,51 & 2,22 \\
\hline PDMI-ETC & 0,05 & 1,17 & 2,59 & 1,61 & 3,19 & 3,07 \\
\hline PDMS-ETC & 0,02 & 1,22 & $-0,97$ & 1,47 & $-2,97$ & 2,43 \\
\hline \multicolumn{7}{|c|}{ TRANSVERSAL } \\
\hline GO-EIC & 0,52 & 2,28 & 0,13 & 3,50 & $-0,14$ & 3,15 \\
\hline PPC-EIC & $-0,37$ & 3,17 & 0,28 & 2,74 & 0,37 & 2,46 \\
\hline PDMI-EIC & 0,07 & 3,62 & $-1,03$ & 4,58 & $-1,39$ & 4,19 \\
\hline PDMS-EIC & 0,36 & 3,28 & 0,72 & 4,06 & 0,72 & 3,49 \\
\hline LMM-EIC & $-0,10$ & 2,43 & $-1,16$ & 3,66 & $-0,79$ & 2,24 \\
\hline LMDFEIC & 0,23 & 2,13 & $-1,32$ & 2,60 & $-0,32$ & 2,52 \\
\hline LMDS-EIC & 0,23 & 1,92 & 0,75 & 2,52 & $-0,43$ & 2,34 \\
\hline
\end{tabular}


TABELA 2 - Sistema de Coordenadas do Assoalho Craniano

ANTERO-POSTERIOR

\begin{tabular}{l|c|c|c|c|c|c}
\hline \multirow{2}{*}{ VARIÁVEIS } & Médias & D.P. & Médias & D.P. & Médias & D.P. \\
\cline { 2 - 7 } & $\begin{array}{c}\text { Oclusão } \\
\text { Normal }\end{array}$ & $\begin{array}{c}\text { Oclusão } \\
\text { Normal }\end{array}$ & $\begin{array}{c}\text { Classe II, } \\
\text { sub. }\end{array}$ & $\begin{array}{c}\text { Classe II, } \\
\text { sub. }\end{array}$ & $\begin{array}{c}\text { Classe II, } \\
\text { sub. } \\
\text { tratado }\end{array}$ & $\begin{array}{c}\text { Classe II, } \\
\text { sub. } \\
\text { tratado }\end{array}$ \\
\hline PCM-ETE & $-1,07$ & 1,75 & $-0,58$ & 2,00 & $-0,62$ & 2,29 \\
\hline GO-ETE & 0,94 & 1,96 & 1,04 & 2,14 & 0,56 & 2,38 \\
\hline PPC-ETE & 0,68 & 2,02 & 0,70 & 2,45 & 1,06 & 2,21 \\
\hline PDMI-ETE & 0,60 & 1,20 & 2,89 & 1,57 & 3,50 & 3,08 \\
\hline PDMS-ETE & 0,60 & 1,23 & $-0,67$ & 1,49 & $-2,67$ & 2,59 \\
\hline \multicolumn{7}{|c|}{ TRANSVERSAL } \\
\hline PCM-EIE & 0,19 & 1,17 & 0,09 & 1,86 & 0,28 & 1,85 \\
\hline GO-EIE & 0,37 & 2,20 & $-0,15$ & 3,43 & $-0,21$ & 3,33 \\
\hline PPC-EIE & $-1,12$ & 3,19 & $-0,25$ & 3,32 & $-0,05$ & 2,89 \\
\hline PDMI-EIE & $-0,96$ & 3,99 & $-1,71$ & 4,71 & $-1,97$ & 4,55 \\
\hline PDMS-EIE & $-0,64$ & 3,56 & 0,03 & 4,34 & 0,11 & 4,00 \\
\hline LMM-EIE & $-0,91$ & 2,71 & $-1,64$ & 3,91 & $-1,25$ & 2,47 \\
\hline LMDIEIE & $-0,55$ & 2,49 & $-1,80$ & 2,79 & $-0,80$ & 2,57 \\
\hline LMDS-EIE & $-0,58$ & 2,30 & 0,24 & 2,88 & $-0,94$ & 2,46 \\
\hline
\end{tabular}

TABELA 3 - Sistema de Coordenadas Zigomaticomaxilares

\section{ANTERO-POSTERIOR}

\begin{tabular}{l|c|c|c|c|c|c}
\hline \multirow{2}{*}{ VARIÁVEIS } & Médias & D.P. & Médias & D.P. & Médias & D.P. \\
\cline { 2 - 7 } & Oclusão & Oclusão & Classe II, & Classe II, & $\begin{array}{c}\text { Classe II, } \\
\text { sub. } \\
\text { sub. } \\
\text { sub. }\end{array}$ & $\begin{array}{c}\text { Classe II, } \\
\text { sub. } \\
\text { tratado }\end{array}$ \\
\hline PDMI-ETPTM & 0,21 & 1,58 & 2,98 & 2,19 & 2,98 & 3,61 \\
\hline PDMS-ETPTM & 0,19 & 1,53 & $-0,57$ & 1,57 & $-3,19$ & 3,03 \\
\hline \multicolumn{7}{|c}{ TRANSVERSAL } \\
\hline VA-EIPTM & $-0,32$ & 1,27 & 0,47 & 1,03 & 0,89 & 1,69 \\
\hline VP-EIPTM & 0,04 & 0,86 & 0,28 & 0,87 & 0,45 & 0,96 \\
\hline PDMI-EIPTM & 0,92 & 3,58 & $-1,28$ & 3,65 & $-0,68$ & 3,73 \\
\hline PDMS-EIPTM & 1,19 & 3,26 & 0,43 & 3,14 & 1,42 & 3,12 \\
\hline LMDS-EIPTM & 0,68 & 2,52 & 0,31 & 2,13 & 0,02 & 2,39 \\
\hline LMM-EIPTM & 0,33 & 2,73 & $-1,53$ & 2,99 & $-0,29$ & 2,51 \\
\hline LMDIEIPTM & 0,69 & 2,53 & $-1,71$ & 2,22 & 0,16 & 2,46 \\
\hline
\end{tabular}

TABELA 4 - Sistema de Coordenadas Dentárias

\begin{tabular}{l|c|c|c|c|c|c}
\hline \multirow{2}{*}{ VARIÁVEIS } & Médias & D.P. & Médias & D.P. & Médias & D.P. \\
\cline { 2 - 7 } & $\begin{array}{c}\text { Oclusão } \\
\text { Normal }\end{array}$ & $\begin{array}{c}\text { Oclusão } \\
\text { Normal }\end{array}$ & $\begin{array}{c}\text { Classe II, } \\
\text { sub. }\end{array}$ & $\begin{array}{c}\text { Classe II, } \\
\text { sub. }\end{array}$ & $\begin{array}{c}\text { Classe II, } \\
\text { sub. } \\
\text { tratado }\end{array}$ & $\begin{array}{c}\text { Classe II, } \\
\text { sub. } \\
\text { tratado }\end{array}$ \\
\hline LMDHEIMI & 0,24 & 0,79 & 1,04 & 1,00 & 2,81 & 3,02 \\
\hline LMM-EIMI & $-0,11$ & 1,12 & 1,19 & 2,14 & 2,22 & 2,48 \\
\hline LMDS-EIMI & 0,25 & 0,85 & 3,43 & 1,40 & 2,85 & 3,11 \\
\hline LMDHEIMS & 0,04 & 0,82 & $-2,28$ & 1,18 & $-2,72$ & 2,65 \\
\hline LMDS-EIMS & 0,05 & 0,73 & $-0,30$ & 1,18 & $-3,01$ & 2,66 \\
\hline LMM-EIMS & $-0,33$ & 1,12 & $-2,10$ & 2,01 & $-3,05$ & 1,97 \\
\hline
\end{tabular}


TABELA 5 - Medidas Angulares

\begin{tabular}{l|c|c|c|c|c|c}
\hline \multirow{2}{*}{ VARIÁVEIS } & Médias & D.P. & Médias & D.P. & Médias & D.P. \\
\cline { 2 - 7 } & $\begin{array}{c}\text { Oclusão } \\
\text { Normal }\end{array}$ & $\begin{array}{c}\text { Oclusão } \\
\text { Normal }\end{array}$ & $\begin{array}{c}\text { Classe II, } \\
\text { sub. }\end{array}$ & $\begin{array}{c}\text { Classe II, } \\
\text { sub. }\end{array}$ & $\begin{array}{c}\text { Classe II, } \\
\text { sub. } \\
\text { tratado }\end{array}$ & $\begin{array}{c}\text { Classe II, } \\
\text { sub. } \\
\text { tratado }\end{array}$ \\
\hline EIE.EIC & 0,45 & 0,93 & 0,23 & 1,06 & 0,32 & 1,21 \\
\hline ETE.ETC & 0,57 & 0,91 & 0,33 & 1,10 & 0,34 & 1,24 \\
\hline ETPTM.ETC & 0,18 & 1,49 & 0,41 & 1,52 & $-0,20$ & 2,02 \\
\hline ETPTM.ETE & $-0,40$ & 1,75 & 0,07 & 1,45 & $-0,55$ & 1,84 \\
\hline ETMI.ETE & $-0,61$ & 1,26 & $-3,03$ & 1,66 & $-3,82$ & 3,34 \\
\hline ETMI.ETC & $-0,04$ & 1,24 & $-2,69$ & 1,62 & $-3,47$ & 3,32 \\
\hline ETMI.ETPTM & $-0,23$ & 1,73 & $-3,09$ & 2,20 & $-3,26$ & 3,94 \\
\hline ETMS.ETE & $-0,60$ & 1,27 & 0,70 & 1,55 & 2,88 & 2,79 \\
\hline ETMS.ETC & $-0,02$ & 1,27 & 1,02 & 1,56 & 3,23 & 2,62 \\
\hline ETMS.ETPTM & $-0,19$ & 1,61 & 0,63 & 1,61 & 3,42 & 3,27 \\
\hline
\end{tabular}

TABELA 6 - Variáveis Adicionais

\begin{tabular}{l|c|c|c|c|c|c}
\hline \multirow{2}{*}{ VARIÁVEIS } & Médias & D.P. & Médias & D.P. & Médias & D.P. \\
\cline { 2 - 7 } & $\begin{array}{c}\text { Oclusão } \\
\text { Normal }\end{array}$ & $\begin{array}{c}\text { Oclusão } \\
\text { Normal }\end{array}$ & $\begin{array}{c}\text { Classe II, } \\
\text { sub. }\end{array}$ & $\begin{array}{c}\text { Classe II, } \\
\text { sub. }\end{array}$ & $\begin{array}{c}\text { Classe II, } \\
\text { sub. } \\
\text { tratado }\end{array}$ & $\begin{array}{c}\text { Classe II, } \\
\text { sub. } \\
\text { tratado }\end{array}$ \\
\hline PCM-LMM & 0,52 & 2,30 & 1,65 & 4,06 & 0,91 & 2,39 \\
\hline PCM-CMM & 0,97 & 2,54 & 1,92 & 3,11 & 1,15 & 2,49 \\
\hline POSM & 0,18 & 1,82 & $-0,83$ & 1,96 & $-0,92$ & 1,90 \\
\hline POSMS & 0,09 & 2,08 & 0,00 & 2,51 & 1,21 & 2,16 \\
\hline
\end{tabular}

TABELA 7 - RADIOGRAFIA PÓSTERO-ANTERIOR

\begin{tabular}{|c|c|c|c|c|c|c|}
\hline \multirow[b]{2}{*}{ VARIÁVEIS } & Médias & D.P. & Médias & D.P. & Médias & D. P. \\
\hline & $\begin{array}{l}\text { Oclusão } \\
\text { Normal }\end{array}$ & $\begin{array}{l}\text { Oclusão } \\
\text { Normal }\end{array}$ & $\begin{array}{c}\text { Classe II, } \\
\text { sub. }\end{array}$ & $\begin{array}{c}\text { Classe II, } \\
\text { sub. }\end{array}$ & $\begin{array}{c}\text { Classe II, } \\
\text { sub. } \\
\text { tratado }\end{array}$ & $\begin{array}{c}\text { Classe II, } \\
\text { sub. } \\
\text { tratado }\end{array}$ \\
\hline ÁPLANOZ & 89,90 & 1,27 & 89,69 & 1,94 & 90,04 & 1,33 \\
\hline ÁPLOCLUSAL & 89,34 & 1,74 & 89,84 & 2,14 & 89,72 & 2,53 \\
\hline AिPLANTEG & 88,63 & 1,51 & 88,47 & 2,48 & 89,25 & 2,49 \\
\hline DESVENA & $-0,18$ & 1,58 & $-0,32$ & 2,25 & $-0,09$ & 1,51 \\
\hline DESMAND & 0,78 & 3,10 & 2,00 & 3,30 & 0,68 & 2,90 \\
\hline A1 & $-0,08$ & 1,69 & $-0,35$ & 2,49 & 0,47 & 2,43 \\
\hline $\mathrm{B} 1$ & $-0,14$ & 1,87 & 1,63 & 2,54 & 0,20 & 2,61 \\
\hline ÁANT & $-0,51$ & 2,82 & $-3,05$ & 2,56 & $-2,28$ & 3,15 \\
\hline DISTZ & $-0,11$ & 2,18 & $-0,01$ & 2,71 & $-0,29$ & 2,59 \\
\hline DISTCO & 0,12 & 4,05 & $-0,07$ & 4,39 & 0,61 & 4,28 \\
\hline DISTZA & 0,34 & 3,49 & $-0,19$ & 4,58 & 0,76 & 4,02 \\
\hline DISTNC & 0,84 & 2,88 & 0,94 & 3,82 & 0,84 & 3,05 \\
\hline DISTJ & 0,41 & 2,98 & 0,57 & 4,23 & 1,14 & 3,18 \\
\hline DISTAG & $-1,49$ & 5,15 & $-0,86$ & 5,29 & 0,66 & 4,63 \\
\hline ALTA6 & 0,45 & 1,68 & $-1,30$ & 1,92 & 0,33 & 2,27 \\
\hline CO-AG & 2,48 & 2,36 & 2,01 & 3,77 & 1,30 & 4,17 \\
\hline CO-ME & 1,11 & 2,98 & 1,61 & 2,97 & 1,22 & 3,56 \\
\hline ME-AG & $-1,09$ & 2,80 & 1,12 & 3,49 & $-14,9$ & 4,26 \\
\hline
\end{tabular}


Análise intra-examinador da precisão da metodologia empregada: apresentação dos erros casuais (DAHLBERG ${ }^{37}$ ), das médias, dos desvios padrão (D.P.) das diferenças e nível de significância estatística dos erros sistemáticos $(p)$, entre os pares dos traçados repetidos

Houve diferenças estatisticamente significantes, para o teste $t$ dependente, para seis variáveis $(p<0,05)$.

RADIOGRAFIA SUBMENTONIANA

TABELA 8 - Sistema de Coordenadas Mandibulares

\begin{tabular}{l|c|c|c|c}
\hline \multicolumn{5}{c}{ ÁNTERO-POSTERIOR } \\
\hline VARIÁVEIS & DAHLBERG & $\begin{array}{c}\text { MÉDIA } \\
\text { DIFERENÇA }\end{array}$ & $\begin{array}{c}\text { D.P. } \\
\text { DIFERENÇA }\end{array}$ & $\mathbf{p}$ \\
\hline GO-ETC & 0,66 & 0,06 & 0,98 & 0,851796 \\
\hline PPC-ETC & 0,90 & 0,36 & 1,29 & 0,403568 \\
\hline PDMI-ETC & 0,43 & $-0,19$ & 0,62 & 0,361068 \\
\hline PDMS-ETC & 0,52 & $-0,46$ & 0,60 & 0,040796 \\
\hline \multicolumn{5}{|c|}{ TRANSVERSAL } \\
\hline GO-EIC & 0,73 & $-0,24$ & 1,06 & 0,496102 \\
\hline PPC-EIC & 1,20 & $-0,76$ & 1,61 & 0,170319 \\
\hline PDMI-EIC & 1,70 & $-0,02$ & 2,54 & 0,980713 \\
\hline PDMS-EIC & 0,98 & $-0,38$ & 1,40 & 0,415465 \\
\hline LMM-EIC & 1,02 & $-0,69$ & 1,34 & 0,139275 \\
\hline LMDI-EIC & 0,57 & $-0,50$ & 0,68 & 0,045893 \\
\hline LMDS-EIC & 0,55 & $-0,38$ & 0,72 & 0,129839 \\
\hline
\end{tabular}

TABELA 9 - Sistema de Coordenadas do Assoalho Craniano

\begin{tabular}{l|c|c|c|c}
\hline \multicolumn{5}{c}{ ÂNTERO-POSTERIOR } \\
\hline \multicolumn{1}{c|}{ VARIÁVEIS } & DAHLBERG & $\begin{array}{c}\text { MÉDIA } \\
\text { DIFERENÇA }\end{array}$ & $\begin{array}{c}\text { D.P. } \\
\text { DIFERENÇA }\end{array}$ & $\mathbf{p}$ \\
\hline PCM-ETE & 0,79 & 0,09 & 1,18 & 0,815226 \\
\hline GO-ETE & 0,59 & $-0,45$ & 0,74 & 0,087088 \\
\hline PPC-ETE & 0,57 & 0,33 & 0,79 & 0,219270 \\
\hline PDMI-ETE & 0,75 & $-0,41$ & 1,04 & 0,246545 \\
\hline PDMS-ETE & 0,70 & $-0,01$ & 1,04 & 0,976496 \\
\hline \multicolumn{5}{|c|}{ TRANSVERSAL } \\
\hline PCM-EIE & 0,60 & 0,05 & 0,89 & 0,863457 \\
\hline GO-EIE & 0,40 & $-0,08$ & 0,59 & 0,679264 \\
\hline PPC-EIE & 0,85 & $-0,70$ & 1,03 & 0,060474 \\
\hline PDMI-EIE & 1,12 & 0,04 & 1,68 & 0,941655 \\
\hline PDMS-EIE & 1,02 & $-0,20$ & 1,51 & 0,686995 \\
\hline LMM-EIE & 0,78 & $-0,32$ & 1,12 & 0,392724 \\
\hline LMDI-EIE & 0,55 & $-0,40$ & 0,70 & 0,107939 \\
\hline LMDS-EIE & 0,58 & $-0,34$ & 0,79 & 0,209086 \\
\hline
\end{tabular}


TABELA 10 - Sistema de Coordenadas Zigomaticomaxilares

\begin{tabular}{l|c|c|c|c}
\hline \multicolumn{5}{c}{$\hat{\text { ANTERO-POSTERIOR }}$} \\
\hline VARIÁVEIS & DAHLBERG & $\begin{array}{c}\text { MEDIA } \\
\text { DIFERENÇA }\end{array}$ & $\begin{array}{c}\text { D.P. } \\
\text { DIFERENÇA }\end{array}$ & $\mathbf{p}$ \\
\hline PDMI-ETPTM & 1,18 & $-0,55$ & 1,66 & 0,324140 \\
\hline PDMS-ETPTM & 0,90 & 0,74 & 1,10 & 0,063616 \\
\hline \multicolumn{5}{l}{ TRANSVERSAL } \\
\hline VA-EIPTM & 0,83 & 0,61 & 1,06 & 0,102960 \\
\hline VP-EIPTM & 0,59 & 0,32 & 0,82 & 0,250036 \\
\hline PDMI-EIPTM & 1,43 & $-0,34$ & 2,11 & 0,623620 \\
\hline PDMS-EIPTM & 1,81 & 0,66 & 2,61 & 0,445273 \\
\hline LMDS-EIPTM & 1,35 & 1,79 & 0,69 & 0,000020 \\
\hline LMM-EIPTM & 1,31 & 1,45 & 1,21 & 0,004408 \\
\hline LMDI-EIPTM & 1,28 & 1,66 & 0,77 & 0,000080 \\
\hline
\end{tabular}

TABELA 11 - Sistema de Coordenadas Dentárias

\begin{tabular}{|c|c|c|c|c|}
\hline \multicolumn{5}{|c|}{ TRANSVERSAL } \\
\hline VARIÁVEIS & DAHLBERG & $\begin{array}{c}\text { MÉDIA } \\
\text { DIFERENÇA }\end{array}$ & $\begin{array}{c}\text { D.P. } \\
\text { DIFERENÇA }\end{array}$ & $\mathbf{p}$ \\
\hline LMDI-EIMI & 0,44 & $-0,09$ & 0,66 & 0,677550 \\
\hline LMM-EIMI & 0,74 & $-0,14$ & 1,09 & 0,695062 \\
\hline LMDS-EIMI & 0,42 & $-0,07$ & 0,63 & 0,734425 \\
\hline LMDI-EIMS & 0,56 & $-0,24$ & 0,80 & 0,370866 \\
\hline LMDS-EIMS & 0,70 & $-0,38$ & 0,97 & 0,246947 \\
\hline LMM-EIMS & 0,74 & $-0,32$ & 1,05 & 0,362043 \\
\hline
\end{tabular}

TABELA 12 - Medidas Angulares

\begin{tabular}{l|c|c|c|c}
\hline \multicolumn{1}{c}{ VARIÁVEIS } & DAHLBERG & $\begin{array}{c}\text { MÉDIA } \\
\text { DIFERENÇA }\end{array}$ & $\begin{array}{c}\text { D.P. } \\
\text { DIFERENÇA }\end{array}$ & $\mathbf{p}$ \\
\hline EIE.EIC & 0,48 & $-0,08$ & 0,71 & 0,732036 \\
\hline ETE.ETC & 0,41 & 0,06 & 0,61 & 0,764711 \\
\hline ETPTM.ETC & 0,84 & 0,66 & 1,05 & 0,078606 \\
\hline ETPTM.ETE & 1,11 & 0,93 & 1,34 & 0,057061 \\
\hline ETMI.ETE & 0,81 & $-0,44$ & 1,12 & 0,249250 \\
\hline ETMI.ETC & 0,50 & $-0,20$ & 0,71 & 0,399361 \\
\hline ETMI.ETPTM & 1,36 & $-0,62$ & 1,93 & 0,336853 \\
\hline ETMS.ETE & 0,76 & 0,06 & 1,14 & 0,871535 \\
\hline ETMS.ETC & 0,52 & $-0,42$ & 0,65 & 0,071800 \\
\hline ETMS.ETPTM & 1,03 & 0,85 & 1,26 & 0,062565 \\
\hline
\end{tabular}


TABELA 13 - Variáveis Adicionais

\begin{tabular}{l|c|c|c|c}
\hline \multicolumn{1}{c|}{ VARIÁVEIS } & DAHLBERG & $\begin{array}{c}\text { MÉDIA } \\
\text { DIFERENÇA }\end{array}$ & $\begin{array}{c}\text { D.P. } \\
\text { DIFERENÇA }\end{array}$ & $\mathbf{p}$ \\
\hline PCM-LMM & 0,82 & $-0,38$ & 1,16 & 0,330007 \\
\hline PCM-CMM & 1,29 & $-0,01$ & 1,93 & 0,987308 \\
\hline POSM & 0,99 & $-0,29$ & 1,45 & 0,543513 \\
\hline POSMS & 1,11 & 0,04 & 1,66 & 0,941215 \\
\hline
\end{tabular}

TABELA 14 - RADIOGRAFIA PÓSTERO-ANTERIOR

\begin{tabular}{l|c|c|c|c}
\hline \multicolumn{1}{c|}{ VARIÁVEIS } & DAHLBERG & $\begin{array}{c}\text { MEDIA } \\
\text { DIFERENÇA }\end{array}$ & $\begin{array}{c}\text { D.P. } \\
\text { DIFERENÇA }\end{array}$ & $\mathbf{p}$ \\
\hline$\hat{\text { APLANOZ }}$ & 0,93 & 0,57 & 1,26 & 0,187913 \\
\hline$\hat{\text { ÂPLOCLUSAL }}$ & 1,26 & 0,67 & 1,74 & 0,254901 \\
\hline ÂPLANTEG & 0,98 & $-0,84$ & 1,16 & 0,048770 \\
\hline DESVENA & 1,18 & $-0,35$ & 1,29 & 0,415080 \\
\hline DESMAND & 1,72 & $-0,63$ & 2,47 & 0,442039 \\
\hline A1 & 1,21 & $-0,23$ & 1,79 & 0,695206 \\
\hline B1 & 1,30 & $-0,26$ & 1,92 & 0,679842 \\
\hline ÂNT & 1,15 & 0,32 & 1,68 & 0,563724 \\
\hline DISTZ & 1,44 & $-0,52$ & 2,08 & 0,450078 \\
\hline DISTCO & 1,21 & $-0,10$ & 1,80 & 0,864799 \\
\hline DISTZA & 0,94 & 0,44 & 1,32 & 0,321093 \\
\hline DISTNC & 1,42 & $-0,04$ & 2,12 & 0,953780 \\
\hline DISTJ & 1,79 & $-0,33$ & 2,65 & 0,703473 \\
\hline DISTAG & 2,38 & $-0,39$ & 3,53 & 0,734891 \\
\hline ALTA6 & 1,58 & $-0,51$ & 2,29 & 0,500022 \\
\hline CO-AG & 1,40 & 0,43 & 2,05 & 0,523857 \\
\hline CO-ME & 1,08 & $-0,11$ & 1,61 & 0,834734 \\
\hline ME-AG & 0,89 & 0,69 & 1,11 & 0,082971 \\
\hline
\end{tabular}


Resultados do teste $t$ independente, entre os grupos de oclusão normal e de Classe II, subdivisão, não tratado (JANSON ${ }^{73}$ )

(Grupo 3 x Grupo 1)

RADIOGRAFIA SUBMENTONIANA

TABELA 15 - Sistema de Coordenadas Mandibulares

ÁNTERO-POSTERIOR

\begin{tabular}{l|c|c|c|c|c|c|c}
\hline \multirow{2}{*}{ VARIÁVEIS } & Média & D.P. & Média & D.P. & Valor t & gl & p \\
\cline { 2 - 9 } & $\begin{array}{c}\text { Oclusão } \\
\text { Normal }\end{array}$ & $\begin{array}{c}\text { Oclusão } \\
\text { Normal }\end{array}$ & $\begin{array}{c}\text { Classe II, } \\
\text { sub. }\end{array}$ & $\begin{array}{c}\text { Classe II, } \\
\text { sub. }\end{array}$ & & & \\
\hline GO-ETC & 1,21 & 1,22 & 1,33 & 0,98 & $-0,39$ & 58 & 0,694501 \\
\hline PPC-ETC & 1,32 & 0,85 & 1,57 & 1,07 & $-0,99$ & 58 & 0,322679 \\
\hline PDMI-ETC & 0,96 & 0,64 & 2,62 & 1,56 & $-5,37$ & 58 & 0,000001 \\
\hline PDMS-ETC & 0,96 & 0,72 & 1,48 & 0,93 & $-2,40$ & 58 & 0,019511 \\
\hline \multicolumn{7}{|c|}{ TRANSVERSAL } \\
\hline GO-EIC & 1,95 & 1,25 & 2,59 & 2,30 & $-1,34$ & 58 & 0,185227 \\
\hline PPC-EIC & 2,58 & 1,82 & 2,05 & 1,80 & 1,11 & 58 & 0,269083 \\
\hline PDMI-EIC & 2,94 & 2,04 & 3,63 & 2,91 & $-1,06$ & 58 & 0,290079 \\
\hline PDMS-EIC & 2,69 & 1,84 & 3,31 & 2,39 & $-1,12$ & 58 & 0,265379 \\
\hline LMM-EIC & 1,88 & 1,50 & 2,68 & 2,70 & $-1,41$ & 58 & 0,162652 \\
\hline LMDI-EIC & 1,72 & 1,24 & 2,20 & 1,88 & $-1,17$ & 58 & 0,245243 \\
\hline LMDS-EIC & 1,55 & 1,12 & 1,93 & 1,75 & $-0,99$ & 58 & 0,322370 \\
\hline
\end{tabular}

TABELA 16 - Sistema de Coordenadas do Assoalho Craniano

\begin{tabular}{|c|c|c|c|c|c|c|c|}
\hline \multicolumn{8}{|c|}{ ÁNTERO-POSTERIOR } \\
\hline \multirow[b]{2}{*}{ VARIÁVEIS } & Média & D.P. & Média & D.P. & Valor t & gl & $p$ \\
\hline & $\begin{array}{c}\text { Oclusão } \\
\text { Normal }\end{array}$ & $\begin{array}{c}\text { Oclusão } \\
\text { Normal }\end{array}$ & $\begin{array}{c}\text { Classe II, } \\
\text { sub. }\end{array}$ & $\begin{array}{c}\text { Classe II, } \\
\text { sub. }\end{array}$ & & & \\
\hline PCM-ETE & 1,59 & 1,27 & 1,58 & 1,33 & 0,02 & 58 & 0,976412 \\
\hline GO-ETE & 1,63 & 1,42 & 1,90 & 1,40 & $-0,73$ & 58 & 0,462829 \\
\hline PPC-ETE & 1,68 & 1,28 & 2,08 & 1,42 & $-1,16$ & 58 & 0,249434 \\
\hline PDMI-ETE & 1,04 & 0,84 & 2,89 & 1,57 & $-5,65$ & 58 & 0,000000 \\
\hline PDMS-ETE & 1,02 & 0,90 & 1,27 & 1,00 & $-1,03$ & 58 & 0,303972 \\
\hline \multicolumn{8}{|c|}{ TRANSVERSAL } \\
\hline PCM-EIE & 0,95 & 0,68 & 1,45 & 1,13 & $-2,07$ & 58 & 0,041960 \\
\hline GO-EIE & 1,78 & 1,31 & 2,70 & 2,06 & $-2,06$ & 58 & 0,043724 \\
\hline PPC-EIE & 2,74 & 1,92 & 2,58 & 2,05 & 0,31 & 58 & 0,756546 \\
\hline PDMI-EIE & 3,26 & 2,41 & 3,96 & 2,99 & $-0,99$ & 58 & 0,325915 \\
\hline PDMS-EIE & 2,86 & 2,15 & 3,54 & 2,42 & $-1,14$ & 58 & 0,255508 \\
\hline LMM-EIE & 2,13 & 1,87 & 3,39 & 2,48 & $-2,21$ & 58 & 0,030549 \\
\hline LMDI-EIE & 1,90 & 1,67 & 2,52 & 2,14 & $-1,25$ & 58 & 0,215073 \\
\hline LMDS-EIE & 1,94 & 1,32 & 2,40 & 1,55 & $-1,23$ & 58 & 0,222254 \\
\hline
\end{tabular}


TABELA 17 - Sistema de Coordenadas Zigomaticomaxilares

\section{ÂNTERO-POSTERIOR}

\begin{tabular}{l|c|c|c|c|c|c|c}
\hline \multirow{2}{*}{ VARIÁVEIS } & Média & D.P. & Média & D.P. & Valor t & gl & P \\
\cline { 2 - 9 } & $\begin{array}{c}\text { Oclusão } \\
\text { normal }\end{array}$ & $\begin{array}{c}\text { Oclusão } \\
\text { normal }\end{array}$ & $\begin{array}{c}\text { Classe II, } \\
\text { sub. }\end{array}$ & $\begin{array}{c}\text { Classe II, } \\
\text { sub. }\end{array}$ & & & \\
\hline PDMI-ETPTM & $\mathbf{1 , 2 7}$ & $\mathbf{0 , 9 5}$ & $\mathbf{3 , 1 5}$ & $\mathbf{1 , 9 2}$ & $-4,81$ & 58 & $\mathbf{0 , 0 0 0 0 1 1}$ \\
\hline PDMS-ETPTM & 1,23 & 0,90 & 1,33 & 0,90 & 0,38 & 58 & 0,704767 \\
\hline \multicolumn{7}{|c|}{ TRANSVERSAL } \\
\hline VA-EIPTM & 1,08 & 0,72 & 0,89 & 0,69 & 1,03 & 58 & 0,305098 \\
\hline VP-EIPTM & 0,64 & 0,56 & 0,68 & 0,60 & $-0,21$ & 58 & 0,827028 \\
\hline PDMI-EIPTM & 2,52 & 2,66 & 3,17 & 2,16 & $-1,02$ & 58 & 0,309114 \\
\hline PDMS-EIPTM & 2,26 & 2,61 & 2,57 & 1,79 & $-0,54$ & 58 & 0,590546 \\
\hline LMDS-EIPTM & 1,82 & 1,85 & 1,75 & 1,21 & 0,17 & 58 & 0,863597 \\
\hline LMM-EIPTM & 1,94 & 1,92 & 2,41 & 2,30 & $-0,86$ & 58 & 0,392140 \\
\hline LMDI-EIPTM & 1,76 & 1,91 & 2,15 & 1,78 & $-0,80$ & 58 & 0,426225 \\
\hline
\end{tabular}

TABELA 18 - Sistema de Coordenadas Dentárias

\section{TRANSVERSAL}

\begin{tabular}{l|c|c|c|c|c|c|c}
\hline \multirow{2}{*}{ VARIÁVEIS } & Média & D.P. & Média & D.P. & Valor t & gl & p \\
\cline { 2 - 9 } & $\begin{array}{c}\text { Oclusão } \\
\text { Normal }\end{array}$ & $\begin{array}{c}\text { Oclusão } \\
\text { Normal }\end{array}$ & $\begin{array}{c}\text { Classe II, } \\
\text { sub. }\end{array}$ & $\begin{array}{c}\text { Classe II, } \\
\text { sub. }\end{array}$ & & & \\
\hline LMDI-EIMI & 0,63 & 0,52 & 1,18 & 0,82 & $-3,09$ & 58 & 0,002986 \\
\hline LMM-EIMI & 0,88 & 0,68 & 1,91 & 1,52 & $-3,35$ & 58 & 0,001410 \\
\hline LMDS-EIMI & 0,73 & 0,49 & 3,43 & 1,40 & $-9,91$ & 58 & 0,000000 \\
\hline LMDI-EIMS & 0,62 & 0,52 & 2,31 & 1,12 & $-7,41$ & 58 & 0,000000 \\
\hline LMDS-EIMS & 0,55 & 0,47 & 0,98 & 0,70 & $-2,75$ & 58 & 0,007907 \\
\hline LMM-EIMS & 0,89 & 0,74 & 2,26 & 1,82 & $-3,78$ & 58 & 0,000365 \\
\hline
\end{tabular}

TABELA 19 - Medidas Angulares

\begin{tabular}{l|c|c|c|c|c|c|c}
\hline \multirow{2}{*}{ VARIÁVEIS } & Média & D.P. & Média & D.P. & Valor t & gl & p \\
\cline { 2 - 9 } & $\begin{array}{c}\text { Oclusão } \\
\text { Normal }\end{array}$ & $\begin{array}{c}\text { Oclusão } \\
\text { Normal }\end{array}$ & $\begin{array}{c}\text { Classe II, } \\
\text { sub. }\end{array}$ & $\begin{array}{c}\text { Classe II, } \\
\text { sub. }\end{array}$ & & & \\
\hline EIE.EIC & 0,81 & 0,64 & 0,81 & 0,71 & $-0,01$ & 58 & 0,984947 \\
\hline ETE.ETC & 0,84 & 0,65 & 0,85 & 0,75 & $-0,05$ & 58 & 0,956529 \\
\hline ETPTM.ETC & 1,23 & 0,84 & 1,25 & 0,93 & $-0,08$ & 58 & 0,930867 \\
\hline ETPTM.ETE & 1,46 & 1,02 & 1,01 & 1,02 & 1,70 & 58 & 0,092745 \\
\hline ETMI.ETE & $\mathbf{1 , 0 9}$ & $\mathbf{0 , 8 7}$ & $\mathbf{3 , 0 3}$ & $\mathbf{1 , 6 6}$ & $-5,65$ & $\mathbf{5 8}$ & $\mathbf{0 , 0 0 0 0 0 1}$ \\
\hline ETMI.ETC & $\mathbf{1 , 0 2}$ & $\mathbf{0 , 6 7}$ & $\mathbf{2 , 7 2}$ & $\mathbf{1 , 5 6}$ & $-\mathbf{5 , 4 5}$ & $\mathbf{5 8}$ & $\mathbf{0 , 0 0 0 0 0 1}$ \\
\hline ETMI.ETPTM & $\mathbf{1 , 3 8}$ & $\mathbf{1 , 0 4}$ & $\mathbf{3 , 2 8}$ & $\mathbf{1 , 9 0}$ & $-\mathbf{4 , 7 8}$ & $\mathbf{5 8}$ & $\mathbf{0 , 0 0 0 0 1 2}$ \\
\hline ETMS.ETE & $\mathbf{1 , 0 4}$ & 0,92 & 1,33 & 1,04 & $-1,14$ & 58 & 0,258657 \\
\hline ETMS.ETC & $\mathbf{1 , 0 0}$ & $\mathbf{0 , 7 6}$ & $\mathbf{1 , 5 5}$ & $\mathbf{1 , 0 2}$ & $-\mathbf{2 , 3 6}$ & $\mathbf{5 8}$ & $\mathbf{0 , 0 2 1 3 7 3}$ \\
\hline ETMS.ETPTM & 1,27 & 0,97 & 1,37 & 1,04 & $-0,35$ & 58 & 0,721246 \\
\hline
\end{tabular}


TABELA 20 - Variáveis Adicionais

\begin{tabular}{l|c|c|c|c|c|c|c}
\hline \multirow{2}{*}{ VARIÁVEIS } & Média & D.P. & Média & D.P. & Valor t & gl & p \\
\cline { 2 - 9 } & $\begin{array}{c}\text { Oclusão } \\
\text { Normal }\end{array}$ & $\begin{array}{c}\text { Oclusão } \\
\text { Normal }\end{array}$ & $\begin{array}{c}\text { Classe II, } \\
\text { sub. }\end{array}$ & $\begin{array}{c}\text { Classe II, } \\
\text { sub. }\end{array}$ & & & \\
\hline PCM-LMM & 1,77 & 1,53 & 2,98 & 3,18 & $-1,87$ & 58 & 0,065832 \\
\hline PCM-CMM & 2,25 & 1,49 & 2,53 & 2,62 & $-0,50$ & 58 & 0,617556 \\
\hline POSM & 1,46 & 1,07 & 1,67 & 1,29 & $-0,68$ & 58 & 0,496056 \\
\hline POSMS & 1,69 & 1,16 & 1,96 & 1,52 & $-0,75$ & 58 & 0,455467 \\
\hline
\end{tabular}

TABELA 21 - RADIOGRAFIA PÓSTERO-ANTERIOR

\begin{tabular}{l|c|c|c|c|c|c|c}
\cline { 2 - 8 } VARIÁVEIS & Média & D.P. & Média & D.P. & Valor t & gl & p \\
\cline { 2 - 8 } & $\begin{array}{c}\text { Oclusão } \\
\text { Normal }\end{array}$ & $\begin{array}{c}\text { Oclusão } \\
\text { Normal }\end{array}$ & $\begin{array}{c}\text { Classe II, } \\
\text { sub. }\end{array}$ & $\begin{array}{c}\text { Classe II, } \\
\text { sub. }\end{array}$ & & & \\
\hline ÂPLANOZ & 89,90 & 1,27 & 89,69 & 1,94 & 0,50 & 58 & 0,617678 \\
\hline ÂPLOCLUSAL & 89,34 & 1,74 & 89,84 & 2,14 & $-0,98$ & 58 & 0,329981 \\
\hline ÂPLANTEG & 88,63 & 1,51 & 88,47 & 2,48 & 0,30 & 58 & 0,764147 \\
\hline DESVENA & 1,33 & 0,84 & 1,70 & 1,48 & $-1,20$ & 58 & 0,231228 \\
\hline DESMAND & 2,71 & 1,63 & 3,10 & 2,26 & $-0,76$ & 58 & 0,444504 \\
\hline A1 & 1,40 & 0,90 & 2,07 & 1,39 & $-2,18$ & 58 & 0,032774 \\
\hline B1 & 1,58 & 0,97 & 2,41 & 1,79 & $-2,23$ & 58 & 0,029382 \\
\hline ÂNT & 2,40 & 1,51 & 3,18 & 2,40 & $-1,49$ & 58 & 0,139202 \\
\hline DISTZ & 1,77 & 1,24 & 2,01 & 1,78 & $-0,60$ & 58 & 0,548703 \\
\hline DISTCO & 3,20 & 2,42 & 3,62 & 2,39 & $-0,68$ & 58 & 0,498654 \\
\hline DISTZA & 2,86 & 1,96 & 3,51 & 2,87 & $-1,03$ & 58 & 0,306876 \\
\hline DISTNC & 2,51 & 1,57 & 3,11 & 2,34 & $-1,16$ & 58 & 0,249333 \\
\hline DISTJ & 2,47 & 1,65 & 3,39 & 2,52 & $-1,66$ & 58 & 0,100728 \\
\hline DISTAG & 4,25 & 3,19 & 4,00 & 3,48 & 0,28 & 58 & 0,779126 \\
\hline ALTA6 & 1,37 & 1,05 & 1,72 & 1,54 & $-1,00$ & 58 & 0,318896 \\
\hline CO-AG & 2,70 & 2,10 & 3,31 & 2,65 & $-0,99$ & 58 & 0,325964 \\
\hline CO-ME & 2,26 & 2,21 & 2,51 & 2,24 & $-0,43$ & 58 & 0,665342 \\
\hline ME-AG & 2,28 & 1,92 & 2,90 & 2,18 & $-1,16$ & 58 & 0,248166 \\
\hline
\end{tabular}


Resultados do teste $t$ independente, entre os grupos de oclusão normal e de Classe II, subdivisão, tratado com extrações assimétricas

(Grupo 3 x Grupo 2)

RADIOGRAFIA SUBMENTONIANA

TABELA 22 - Sistema de Coordenadas Mandibulares

ÂNTERO-POSTERIOR

\begin{tabular}{l|c|c|c|c|c|c|c}
\hline \multirow{2}{*}{ VARIÁVEIS } & Média & D.P. & Média & D.P. & Valor t & gl & P \\
\cline { 2 - 9 } & $\begin{array}{c}\text { Oclusão } \\
\text { Normal }\end{array}$ & $\begin{array}{c}\text { Oclusão } \\
\text { Normal }\end{array}$ & $\begin{array}{c}\text { Classe II, } \\
\text { sub. } \\
\text { tratado }\end{array}$ & $\begin{array}{c}\text { Classe II, } \\
\text { sub. } \\
\text { tratado }\end{array}$ & & & \\
\hline GO-ETC & 1,21 & 1,22 & 1,31 & 1,08 & $-0,31$ & 58 & 0,755908 \\
\hline PPC-ETC & 1,32 & 0,85 & 1,73 & 1,46 & $-1,33$ & 58 & 0,185883 \\
\hline PDMI-ETC & $\mathbf{0 , 9 6}$ & $\mathbf{0 , 6 4}$ & $\mathbf{3 , 6 0}$ & $\mathbf{2 , 5 5}$ & $-5,48$ & $\mathbf{5 8}$ & $\mathbf{0 , 0 0 0 0 0 1}$ \\
\hline PDMS-ETC & $\mathbf{0 , 9 6}$ & $\mathbf{0 , 7 2}$ & $\mathbf{3 , 1 2}$ & $\mathbf{2 , 2 3}$ & $-5,01$ & $\mathbf{5 8}$ & $\mathbf{0 , 0 0 0 0 0 5}$ \\
\hline \multicolumn{7}{|c|}{ TRANSVERSAL } \\
\hline GO-EIC & 1,95 & 1,25 & 2,45 & 1,93 & $-1,18$ & 58 & 0,239315 \\
\hline PPC-EIC & 2,58 & 1,82 & 2,01 & 1,42 & 1,33 & 58 & 0,187369 \\
\hline PDMI-EIC & 2,94 & 2,04 & 3,55 & 2,56 & $-1,01$ & 58 & 0,315110 \\
\hline PDMS-EIC & 2,69 & 1,84 & 2,87 & 2,05 & $-0,35$ & 58 & 0,726908 \\
\hline LMM-EIC & 1,88 & 1,50 & 1,75 & 1,57 & 0,32 & 58 & 0,744940 \\
\hline LMDI-EIC & 1,72 & 1,24 & 1,99 & 1,53 & $-0,75$ & 58 & 0,452347 \\
\hline LMDS-EIC & 1,55 & 1,12 & 1,85 & 1,46 & $-0,86$ & 58 & 0,388665 \\
\hline
\end{tabular}

TABELA 23 - Sistema de Coordenadas do Assoalho Craniano

\begin{tabular}{|c|c|c|c|c|c|c|c|}
\hline \multicolumn{8}{|c|}{ ÂNTERO-POSTERIOR } \\
\hline \multirow[b]{2}{*}{ VARIÁVEIS } & Média & D.P. & Média & D.P. & Valor $\mathrm{t}$ & gl & $p$ \\
\hline & $\begin{array}{l}\text { Oclusão } \\
\text { Normal }\end{array}$ & $\begin{array}{l}\text { Oclusão } \\
\text { Normal }\end{array}$ & $\begin{array}{c}\text { Classe II, } \\
\text { sub. } \\
\text { tratado }\end{array}$ & $\begin{array}{c}\text { Classe II, } \\
\text { sub. } \\
\text { tratado }\end{array}$ & & & \\
\hline PCM-ETE & 1,59 & 1,27 & 1,84 & 1,46 & $-0,70$ & 58 & 0,484235 \\
\hline GO-ETE & 1,63 & 1,42 & 1,76 & 1,67 & $-0,34$ & 58 & 0,734869 \\
\hline PPC-ETE & 1,68 & 1,28 & 1,93 & 1,48 & $-0,70$ & 58 & 0,482498 \\
\hline PDMI-ETE & 1,04 & 0,84 & 3,73 & 2,78 & $-5,07$ & 58 & 0,000004 \\
\hline PDMS-ETE & 1,02 & 0,90 & 3,08 & 2,07 & $-5,00$ & 58 & 0,000006 \\
\hline \multicolumn{8}{|c|}{ TRANSVERSAL } \\
\hline PCM-EIE & 0,95 & 0,68 & 1,45 & 1,14 & $-2,04$ & 58 & 0,045443 \\
\hline GO-EIE & 1,78 & 1,31 & 2,52 & 2,13 & $-1,61$ & 58 & 0,111638 \\
\hline PPC-EIE & 2,74 & 1,92 & 2,25 & 1,78 & 1,03 & 58 & 0,303392 \\
\hline PDMI-EIE & 3,26 & 2,41 & 3,88 & 3,03 & $-0,87$ & 58 & 0,387599 \\
\hline PDMS-EIE & 2,86 & 2,15 & 3,29 & 2,19 & $-0,77$ & 58 & 0,443271 \\
\hline LMM-EIE & 2,13 & 1,87 & 2,22 & 1,61 & $-0,19$ & 58 & 0,842745 \\
\hline LMDI-EIE & 1,90 & 1,67 & 2,19 & 1,51 & $-0,71$ & 58 & 0,480135 \\
\hline LMDS-EIE & 1,94 & 1,32 & 2,15 & 1,48 & $-0,55$ & 58 & 0,578083 \\
\hline
\end{tabular}


TABELA 24 - Sistema de Coordenadas Zigomaticomaxilares ÂNTERO-POSTERIOR

\begin{tabular}{l|c|c|c|c|c|c|c}
\hline \multirow{2}{*}{ VARIÁVEIS } & Média & D.P. & Média & D.P. & Valor t & gl & P \\
\cline { 2 - 9 } & $\begin{array}{c}\text { Oclusão } \\
\text { Normal }\end{array}$ & $\begin{array}{c}\text { Oclusão } \\
\text { Normal }\end{array}$ & $\begin{array}{c}\text { Classe II, } \\
\text { sub. } \\
\text { tratado }\end{array}$ & $\begin{array}{c}\text { Classe II, } \\
\text { sub. } \\
\text { tratado }\end{array}$ & & & \\
\hline PDMI-ETPTM & $\mathbf{1 , 2 7}$ & $\mathbf{0 , 9 5}$ & $\mathbf{3 , 6 3}$ & $\mathbf{2 , 9 3}$ & $-\mathbf{4 , 2 0}$ & 58 & $\mathbf{0 , 0 0 0 0 9 1}$ \\
\hline PDMS-ETPTM & $\mathbf{1 , 2 3}$ & $\mathbf{0 , 9 0}$ & $\mathbf{3 , 7 5}$ & $\mathbf{2 , 2 6}$ & $-5,66$ & 58 & $\mathbf{0 , 0 0 0 0 0 0}$ \\
\hline \multicolumn{7}{|c|}{ TRANSVERSAL } \\
\hline VA-EIPTM & 1,08 & 0,72 & 1,51 & 1,14 & $-1,75$ & 58 & 0,083780 \\
\hline VP-EIPTM & 0,64 & 0,56 & 0,82 & 0,66 & $-1,08$ & 58 & 0,282401 \\
\hline PDMI-EIPTM & 2,52 & 2,66 & 2,81 & 2,49 & $-0,43$ & 58 & 0,665174 \\
\hline PDMS-EIPTM & 2,26 & 2,61 & 2,59 & 2,21 & $-0,52$ & 58 & 0,603872 \\
\hline LMDS-EIPTM & 1,82 & 1,85 & 1,97 & 1,29 & $-0,37$ & 58 & 0,706337 \\
\hline LMM-EIPTM & 1,94 & 1,92 & 2,02 & 1,47 & $-0,17$ & 58 & 0,863254 \\
\hline LMDI-EIPTM & 1,76 & 1,91 & 2,03 & 1,35 & $-0,62$ & 58 & 0,536510 \\
\hline
\end{tabular}

TABELA 25 - Sistema de Coordenadas Dentárias

\section{TRANSVERSAL}

\begin{tabular}{l|c|c|c|c|c|c|c}
\hline \multirow{2}{*}{ VARIÁVEIS } & Média & D.P. & Média & D.P. & Valor t & gl & p \\
\cline { 2 - 9 } & $\begin{array}{c}\text { Oclusão } \\
\text { Normal }\end{array}$ & $\begin{array}{c}\text { Oclusão } \\
\text { Normal }\end{array}$ & $\begin{array}{c}\text { Classe II, } \\
\text { sub. } \\
\text { tratado }\end{array}$ & $\begin{array}{c}\text { Classe II, } \\
\text { sub. } \\
\text { tratado }\end{array}$ & & & \\
\hline LMDI-EIMI & 0,63 & 0,52 & 2,93 & 2,90 & $-4,26$ & 58 & 0,000074 \\
\hline LMM-EIMI & 0,88 & 0,68 & 2,50 & 2,18 & $-3,87$ & 58 & 0,000278 \\
\hline LMDS-EIMI & 0,73 & 0,49 & 3,05 & 2,91 & $-4,29$ & 58 & 0,000068 \\
\hline LMDI-EIMS & 0,62 & 0,52 & 3,08 & 2,20 & $-5,94$ & 58 & 0,000000 \\
\hline LMDS-EIMS & 0,55 & 0,47 & 3,23 & 2,38 & $-6,05$ & 58 & 0,000000 \\
\hline LMM-EIMS & 0,89 & 0,74 & 3,09 & 1,91 & $-5,85$ & 58 & 0,000000 \\
\hline
\end{tabular}

TABELA 26 - Medidas Angulares

\begin{tabular}{l|c|c|c|c|c|c|c}
\hline \multirow{2}{*}{ VARIÁVEIS } & Média & D.P. & Média & D.P. & Valor t & gl & P \\
\cline { 2 - 8 } & Oclusão & $\begin{array}{c}\text { Oclusão } \\
\text { Normal }\end{array}$ & $\begin{array}{c}\text { Classe II, } \\
\text { sub. } \\
\text { tratado }\end{array}$ & $\begin{array}{c}\text { Classe II, } \\
\text { sub. } \\
\text { tratado }\end{array}$ & & & \\
\hline EIE.EIC & 0,81 & 0,64 & 0,96 & 0,79 & $-0,84$ & 58 & 0,403046 \\
\hline ETE.ETC & 0,84 & 0,65 & 1,00 & 0,80 & $-0,81$ & 58 & 0,420052 \\
\hline ETPTM.ETC & 1,23 & 0,84 & 1,57 & 1,26 & $-1,22$ & 58 & 0,226298 \\
\hline ETPTM.ETE & 1,46 & 1,02 & 1,55 & 1,10 & $-0,31$ & 58 & 0,753942 \\
\hline ETMI.ETE & 1,09 & $\mathbf{0 , 8 7}$ & $\mathbf{4 , 0 7}$ & $\mathbf{3 , 0 2}$ & $-5,18$ & 58 & $\mathbf{0 , 0 0 0 0 0 3}$ \\
\hline ETMI.ETC & $\mathbf{1 , 0 2}$ & $\mathbf{0 , 6 7}$ & $\mathbf{3 , 9 3}$ & $\mathbf{2 , 7 5}$ & $-5,60$ & 58 & $\mathbf{0 , 0 0 0 0 0 1}$ \\
\hline ETMI.ETPTM & $\mathbf{1 , 3 8}$ & $\mathbf{1 , 0 4}$ & $\mathbf{3 , 9 7}$ & $\mathbf{3 , 1 9}$ & $-4,22$ & 58 & $\mathbf{0 , 0 0 0 0 8 6}$ \\
\hline ETMS.ETE & $\mathbf{1 , 0 4}$ & $\mathbf{0 , 9 2}$ & $\mathbf{3 , 3 2}$ & $\mathbf{2 , 2 3}$ & $-5,16$ & 58 & $\mathbf{0 , 0 0 0 0 0 3}$ \\
\hline ETMS.ETC & $\mathbf{1 , 0 0}$ & $\mathbf{0 , 7 6}$ & $\mathbf{3 , 3 7}$ & $\mathbf{2 , 4 3}$ & $-5,08$ & $\mathbf{5 8}$ & $\mathbf{0 , 0 0 0 0 0 4}$ \\
\hline ETMS.ETPTM & $\mathbf{1 , 2 7}$ & $\mathbf{0 , 9 7}$ & $\mathbf{4 , 0 4}$ & $\mathbf{2 , 4 4}$ & $-5,75$ & $\mathbf{5 8}$ & $\mathbf{0 , 0 0 0 0 0 0}$ \\
\hline
\end{tabular}


TABELA 27 - Variáveis Adicionais

\begin{tabular}{l|c|c|c|c|c|c|c}
\hline \multirow{2}{*}{ VARIÁVEIS } & Média & D.P. & Média & D.P. & $\begin{array}{c}\text { Valor } \\
\mathbf{t}\end{array}$ & $\mathbf{g l}$ & $\mathbf{p}$ \\
\cline { 2 - 8 } & $\begin{array}{c}\text { Oclusão } \\
\text { Normal }\end{array}$ & $\begin{array}{c}\text { Oclusão } \\
\text { Normal }\end{array}$ & $\begin{array}{c}\text { Classe II, } \\
\text { sub. } \\
\text { tratado }\end{array}$ & $\begin{array}{c}\text { Classe II, } \\
\text { sub. } \\
\text { tratado }\end{array}$ & & & \\
\hline PCM-LMM & 1,77 & 1,53 & 1,81 & 1,79 & $-0,08$ & 58 & 0,932578 \\
\hline PCM-CMM & 2,25 & 1,49 & 2,28 & 1,47 & $-0,07$ & 58 & 0,937835 \\
\hline POSM & 1,46 & 1,07 & 1,68 & 1,25 & $-0,71$ & 58 & 0,475375 \\
\hline POSMS & 1,69 & 1,16 & 1,83 & 1,66 & $-0,35$ & 58 & 0,720279 \\
\hline
\end{tabular}

TABELA 28 - RADIOGRAFIA PÓSTERO-ANTERIOR

\begin{tabular}{l|c|c|c|c|c|c|c}
\cline { 2 - 8 } VARIÁVEIS & Média & D.P. & Média & D.P. & Valor t & gl & p \\
\cline { 2 - 8 } & $\begin{array}{c}\text { Oclusão } \\
\text { Normal }\end{array}$ & $\begin{array}{c}\text { Oclusão } \\
\text { Normal }\end{array}$ & $\begin{array}{c}\text { Classe II, } \\
\text { sub. } \\
\text { tratado }\end{array}$ & $\begin{array}{c}\text { Classe II, } \\
\text { sub. } \\
\text { tratado }\end{array}$ & & & \\
\hline ÂPLANOZ & 89,90 & 1,27 & 90,04 & 1,33 & $-0,41$ & 58 & 0,678851 \\
\hline$\hat{\text { APLOCLUSAL }}$ & 89,34 & 1,74 & 89,72 & 2,53 & $-0,67$ & 58 & 0,501709 \\
\hline$\hat{\text { APLANTEG }}$ & 88,63 & 1,51 & 89,25 & 2,49 & $-1,16$ & 58 & 0,247447 \\
\hline DESVENA & 1,33 & 0,84 & 1,20 & 0,90 & 0,56 & 58 & 0,577472 \\
\hline DESMAND & 2,71 & 1,63 & 2,33 & 1,81 & 0,84 & 58 & 0,398915 \\
\hline A1 & 1,40 & 0,90 & 1,92 & 1,52 & $-1,59$ & 58 & 0,116271 \\
\hline B1 & 1,58 & 0,97 & 2,03 & 1,61 & $-1,30$ & 58 & 0,196369 \\
\hline$\hat{\text { AANT }}$ & 2,40 & 1,51 & 3,08 & 2,35 & $-1,32$ & 58 & 0,190768 \\
\hline DISTZ & 1,77 & 1,24 & 2,04 & 1,58 & $-0,74$ & 58 & 0,461305 \\
\hline DISTCO & 3,20 & 2,42 & 3,27 & 2,76 & $-0,10$ & 58 & 0,917295 \\
\hline DISTZA & 2,86 & 1,96 & 2,98 & 2,76 & $-0,19$ & 58 & 0,847014 \\
\hline DISTNC & 2,51 & 1,57 & 2,54 & 1,83 & $-0,06$ & 58 & 0,094615 \\
\hline DISTJ & 2,47 & 1,65 & 2,72 & 1,95 & $-0,53$ & 58 & 0,595158 \\
\hline DISTAG & 4,25 & 3,19 & 3,63 & 2,88 & 0,78 & 58 & 0,433292 \\
\hline ALTA6 & 1,37 & 1,05 & 1,89 & 1,26 & $-1,70$ & 58 & 0,093299 \\
\hline CO-AG & 2,70 & 2,10 & 3,19 & 2,93 & $-0,74$ & 58 & 0,460636 \\
\hline CO-ME & 2,26 & 2,21 & 2,70 & 2,57 & $-0,72$ & 58 & 0,474077 \\
\hline ME-AG & 2,28 & 1,92 & 3,34 & 2,77 & $-1,71$ & 58 & 0,091869 \\
\hline
\end{tabular}


Resultados do teste $t$ independente, entre os grupos de oclusão normal e de Classe II, subdivisão, tratado com extração de um pré-molar superior

(Grupo 3 x subgrupo A)

RADIOGRAFIA SUBMENTONIANA

TABELA 29 - Sistema de Coordenadas Mandibulares

\begin{tabular}{l|c|c|c|c|c|c|c}
\hline \multicolumn{7}{c}{ ÁNTERO-POSTERIOR } \\
\hline \multirow{2}{*}{ VARIÁVEIS } & Média & D.P. & Média & D.P. & Valor t & gl & p \\
\cline { 2 - 10 } & $\begin{array}{c}\text { Oclusão } \\
\text { Normal }\end{array}$ & $\begin{array}{c}\text { Oclusão } \\
\text { Normal }\end{array}$ & $\begin{array}{c}\text { CI II, sub. } \\
\text { trat. 1PM }\end{array}$ & $\begin{array}{c}\text { CI II, sub. } \\
\text { trat. 1PM }\end{array}$ & & & \\
\hline GO-ETC & 1,21 & 1,22 & 1,12 & 1,05 & 0,24 & 45 & 0,806685 \\
\hline PPC-ETC & 1,32 & 0,85 & 1,43 & 1,53 & $-0,33$ & 45 & 0,740622 \\
\hline PDMI-ETC & $\mathbf{0 , 9 6}$ & $\mathbf{0 , 6 4}$ & $\mathbf{2 , 0 7}$ & $\mathbf{1 , 8 6}$ & $-2,97$ & $\mathbf{4 5}$ & $\mathbf{0 , 0 0 4 6 9 4}$ \\
\hline PDMS-ETC & $\mathbf{0 , 9 6}$ & $\mathbf{0 , 7 2}$ & $\mathbf{4 , 4 2}$ & $\mathbf{1 , 8 9}$ & $-8,95$ & $\mathbf{4 5}$ & $\mathbf{0 , 0 0 0 0 0 0}$ \\
\hline \multicolumn{7}{|c|}{ TRANSVERSAL } \\
\hline GO-EIC & 1,95 & 1,25 & 2,80 & 2,04 & $-1,76$ & 45 & 0,085061 \\
\hline PPC-EIC & 2,58 & 1,82 & 1,94 & 1,56 & 1,20 & 45 & 0,236323 \\
\hline PDMI-EIC & 2,94 & 2,04 & 3,47 & 2,48 & $-0,79$ & 45 & 0,430751 \\
\hline PDMS-EIC & 2,69 & 1,84 & 3,15 & 1,99 & $-0,79$ & 45 & 0,429547 \\
\hline LMM-EIC & 1,88 & 1,50 & 1,78 & 1,30 & 0,22 & 45 & 0,822456 \\
\hline LMDI-EIC & 1,72 & 1,24 & 2,17 & 1,44 & $-1,13$ & 45 & 0,264052 \\
\hline LMDS-EIC & 1,55 & 1,12 & 1,97 & 1,46 & $-1,08$ & 45 & 0,283376 \\
\hline
\end{tabular}

TABELA 30 - Sistema de Coordenadas do Assoalho Craniano

ÂNTERO-POSTERIOR

\begin{tabular}{l|c|c|c|c|c|c|c}
\hline \multirow{2}{*}{ VARIÁVEIS } & Média & D.P. & Média & D.P. & Valor t & gl & p \\
\cline { 2 - 9 } & $\begin{array}{c}\text { Oclusão } \\
\text { Normal }\end{array}$ & $\begin{array}{c}\text { Oclusão } \\
\text { Normal }\end{array}$ & $\begin{array}{c}\text { CI II, sub. } \\
\text { trat. 1PM }\end{array}$ & $\begin{array}{c}\text { Cl II, sub. } \\
\text { trat. 1PM }\end{array}$ & & & \\
\hline PCM-ETE & 1,59 & 1,27 & 1,76 & 1,75 & $-0,37$ & 45 & 0,706961 \\
\hline GO-ETE & 1,63 & 1,42 & 1,27 & 1,39 & 0,83 & 45 & 0,406451 \\
\hline PPC-ETE & 1,68 & 1,28 & 1,58 & 1,29 & 0,23 & 45 & 0,815432 \\
\hline PDMI-ETE & $\mathbf{1 , 0 4}$ & $\mathbf{0 , 8 4}$ & $\mathbf{1 , 8 8}$ & $\mathbf{1 , 5 9}$ & $-2,38$ & $\mathbf{4 5}$ & $\mathbf{0 , 0 2 1 2 7 8}$ \\
\hline PDMS-ETE & $\mathbf{1 , 0 2}$ & $\mathbf{0 , 9 0}$ & $\mathbf{4 , 3 0}$ & $\mathbf{1 , 7 9}$ & $-8,33$ & $\mathbf{4 5}$ & $\mathbf{0 , 0 0 0 0 0 0}$ \\
\hline \multicolumn{7}{|c|}{ TRANSVERSAL } \\
\hline PCM-EIE & 0,95 & 0,68 & 1,52 & 1,26 & $-2,00$ & 45 & 0,050702 \\
\hline GO-EIE & 1,78 & 1,31 & 2,89 & 2,50 & $-1,99$ & 45 & 0,052281 \\
\hline PPC-EIE & 2,74 & 1,92 & 2,49 & 1,63 & 0,45 & 45 & 0,650286 \\
\hline PDMI-EIE & 3,26 & 2,41 & 3,55 & 3,21 & $-0,34$ & 45 & 0,731047 \\
\hline PDMS-EIE & 2,86 & 2,15 & 3,21 & 2,55 & $-0,49$ & 45 & 0,621050 \\
\hline LMM-EIE & 2,13 & 1,87 & 1,75 & 1,45 & 0,71 & 45 & 0,480832 \\
\hline LMDI-EIE & 1,90 & 1,67 & 1,93 & 1,56 & $-0,07$ & 45 & 0,943651 \\
\hline LMDS-EIE & 1,94 & 1,32 & 1,95 & 1,57 & $-0,01$ & 45 & 0,988427 \\
\hline
\end{tabular}


TABELA 31 - Sistema de Coordenadas Zigomaticomaxilares

\begin{tabular}{l|c|c|c|c|c|c|c}
\hline \multicolumn{8}{c}{ ÂNTERO-POSTERIOR } \\
\hline \multirow{3}{*}{ VARIÁVEIS } & Média & D.P. & Média & D.P. & Valor t & gl & p \\
\cline { 2 - 9 } & $\begin{array}{c}\text { Oclusão } \\
\text { Normal }\end{array}$ & $\begin{array}{c}\text { Oclusão } \\
\text { Normal }\end{array}$ & $\begin{array}{c}\text { CI II, sub. } \\
\text { trat. 1PM }\end{array}$ & $\begin{array}{c}\text { CI II, sub. } \\
\text { trat. 1PM }\end{array}$ & & & \\
\hline PDMI-ETPTM & $\mathbf{1 , 2 7}$ & $\mathbf{0 , 9 5}$ & $\mathbf{2 , 0 3}$ & $\mathbf{1 , 6 3}$ & $\mathbf{- 2 , 0 3}$ & $\mathbf{4 5}$ & $\mathbf{0 , 0 4 7 3 4 1}$ \\
\hline PDMS-ETPTM & $\mathbf{1 , 2 3}$ & $\mathbf{0 , 9 0}$ & $\mathbf{4 , 8 8}$ & $\mathbf{2 , 1 3}$ & $-\mathbf{8 , 1 9}$ & $\mathbf{4 5}$ & $\mathbf{0 , 0 0 0 0 0 0}$ \\
\hline \multicolumn{7}{|c|}{ TRANSVERSAL } \\
\hline VA-EIPTM & $\mathbf{1 , 0 8}$ & $\mathbf{0 , 7 2}$ & $\mathbf{1 , 6 2}$ & $\mathbf{1 , 1 0}$ & $\mathbf{- 2 , 0 3}$ & $\mathbf{4 5}$ & $\mathbf{0 , 0 4 7 2 9 2}$ \\
\hline VP-EIPTM & 0,64 & 0,56 & 1,00 & 0,72 & $-1,88$ & 45 & 0,066275 \\
\hline PDMI-EIPTM & 2,52 & 2,66 & 2,62 & 2,34 & $-0,12$ & 45 & 0,901191 \\
\hline PDMS-EIPTM & 2,26 & 2,61 & 3,08 & 2,35 & $-1,06$ & 45 & 0,291507 \\
\hline LMDS-EIPTM & 1,82 & 1,85 & 1,79 & 1,27 & 0,05 & 45 & 0,959618 \\
\hline LMM-EIPTM & 1,94 & 1,92 & 2,01 & 1,47 & $-0,12$ & 45 & 0,899717 \\
\hline LMDI-EIPTM & 1,76 & 1,91 & 1,77 & 1,43 & $-0,00$ & 45 & 0,994176 \\
\hline
\end{tabular}

TABELA 32 - Sistema de Coordenadas Dentárias

\begin{tabular}{|c|c|c|c|c|c|c|c|}
\hline \multicolumn{8}{|c|}{ TRANSVERSAL } \\
\hline \multirow[b]{2}{*}{ VARIÁVEIS } & Média & D.P. & Média & D.P. & Valor t & gl & $p$ \\
\hline & $\begin{array}{c}\text { Oclusão } \\
\text { Normal }\end{array}$ & $\begin{array}{c}\text { Oclusão } \\
\text { Normal }\end{array}$ & $\begin{array}{l}\text { CI II, sub. } \\
\text { trat. 1PM }\end{array}$ & $\begin{array}{l}\text { CI II, sub. } \\
\text { trat. 1PM }\end{array}$ & & & \\
\hline LMDI-EIMI & 0,63 & 0,52 & 0,53 & 0,41 & 0,66 & 45 & 0,511269 \\
\hline LMM-EIMI & 0,88 & 0,68 & 0,94 & 1,02 & $-0,24$ & 45 & 0,809409 \\
\hline LMDS-EIMI & 0,73 & 0,49 & 0,67 & 0,64 & 0,37 & 45 & 0,710745 \\
\hline LMDI-EIMS & 0,62 & 0,52 & 4,86 & 0,92 & $-20,18$ & 45 & 0,000000 \\
\hline LMDS-EIMS & 0,55 & 0,47 & 5,20 & 0,77 & $-25,61$ & 45 & 0,000000 \\
\hline LMM-EIMS & 0,89 & 0,74 & 4,40 & 1,22 & $-12,24$ & 45 & 0,000000 \\
\hline
\end{tabular}

TABELA 33 - Medidas Angulares

\begin{tabular}{l|c|c|c|c|c|c|c}
\hline \multirow{2}{*}{ VARIÁVEIS } & Média & D.P. & Média & D.P. & Valor t & gl & p \\
\cline { 2 - 9 } & $\begin{array}{c}\text { Oclusão } \\
\text { Normal }\end{array}$ & $\begin{array}{c}\text { Oclusão } \\
\text { Normal }\end{array}$ & $\begin{array}{c}\text { CI II, sub. } \\
\text { trat. 1PM }\end{array}$ & $\begin{array}{c}\text { CI II, sub. } \\
\text { trat. 1PM }\end{array}$ & & & \\
\hline EIE.EIC & 0,81 & 0,64 & 0,95 & 0,91 & $-0,62$ & 45 & 0,533755 \\
\hline ETE.ETC & 0,84 & 0,65 & 0,95 & 0,95 & $-0,47$ & 45 & 0,636540 \\
\hline ETPTM.ETC & 1,23 & 0,84 & 1,79 & 1,30 & $-1,79$ & 45 & 0,078785 \\
\hline ETPTM.ETE & 1,46 & 1,02 & 1,59 & 1,10 & $-0,40$ & 45 & 0,684152 \\
\hline ETMI.ETE & $\mathbf{1 , 0 9}$ & $\mathbf{0 , 8 7}$ & $\mathbf{2 , 0 5}$ & $\mathbf{1 , 7 4}$ & $\mathbf{- 2 , 5 2}$ & $\mathbf{4 5}$ & $\mathbf{0 , 0 1 5 2 2 3}$ \\
\hline ETMI.ETC & $\mathbf{1 , 0 2}$ & $\mathbf{0 , 6 7}$ & $\mathbf{2 , 2 3}$ & $\mathbf{2 , 0 0}$ & $\mathbf{- 3 , 0 3}$ & $\mathbf{4 5}$ & $\mathbf{0 , 0 0 3 9 9 3}$ \\
\hline ETMI.ETPTM & $\mathbf{1 , 3 8}$ & $\mathbf{1 , 0 4}$ & $\mathbf{2 , 2 2}$ & $\mathbf{1 , 8 0}$ & $\mathbf{- 2 , 0 4}$ & $\mathbf{4 5}$ & $\mathbf{0 , 0 4 6 4 7 0}$ \\
\hline ETMS.ETE & $\mathbf{1 , 0 4}$ & $\mathbf{0 , 9 2}$ & $\mathbf{4 , 6 2}$ & $\mathbf{1 , 9 2}$ & $\mathbf{- 8 , 6 2}$ & $\mathbf{4 5}$ & $\mathbf{0 , 0 0 0 0 0 0}$ \\
\hline ETMS.ETC & $\mathbf{1 , 0 0}$ & $\mathbf{0 , 7 6}$ & $\mathbf{4 , 7 9}$ & $\mathbf{2 , 0 8}$ & $\mathbf{- 9 , 0 0}$ & $\mathbf{4 5}$ & $\mathbf{0 , 0 0 0 0 0 0}$ \\
\hline ETMS.ETPTM & $\mathbf{1 , 2 7}$ & $\mathbf{0 , 9 7}$ & $\mathbf{5 , 2 5}$ & $\mathbf{2 , 3 4}$ & $\mathbf{- 8 , 1 7}$ & $\mathbf{4 5}$ & $\mathbf{0 , 0 0 0 0 0 0}$ \\
\hline
\end{tabular}


TABELA 34 - Variáveis Adicionais

\begin{tabular}{l|c|c|c|c|c|c|c}
\hline \multirow{2}{*}{ VARIÁVEIS } & Média & D.P. & Média & D.P. & Valor t & gl & p \\
\cline { 2 - 9 } & $\begin{array}{c}\text { Oclusão } \\
\text { Normal }\end{array}$ & $\begin{array}{c}\text { Oclusão } \\
\text { Normal }\end{array}$ & $\begin{array}{c}\text { CI II, sub. } \\
\text { trat. 1PM }\end{array}$ & $\begin{array}{c}\text { CI II, sub. } \\
\text { trat. 1PM }\end{array}$ & & & \\
\hline PCM-LMM & 1,77 & 1,53 & 1,79 & 1,65 & $-0,04$ & 45 & 0,965599 \\
\hline PCM-CMM & 2,25 & 1,49 & 2,62 & 1,49 & $-0,81$ & 45 & 0,417796 \\
\hline POSM & 1,46 & 1,07 & 1,66 & 1,35 & $-0,55$ & 45 & 0,583246 \\
\hline POSMS & 1,69 & 1,16 & 1,92 & 2,10 & $-0,48$ & 45 & 0,626760 \\
\hline
\end{tabular}

TABELA 35 - RADIOGRAFIA PÓSTERO-ANTERIOR

\begin{tabular}{|c|c|c|c|c|c|c|c|}
\hline \multirow[b]{2}{*}{ VARIÁVEIS } & Média & D.P. & Média & D.P. & Valor t & gl & $p$ \\
\hline & $\begin{array}{c}\text { Oclusão } \\
\text { Normal }\end{array}$ & $\begin{array}{l}\text { Oclusão } \\
\text { Normal }\end{array}$ & $\begin{array}{l}\text { CI II, sub. } \\
\text { trat. 1PM }\end{array}$ & $\begin{array}{l}\text { CI II, sub. } \\
\text { trat. 1PM }\end{array}$ & & & \\
\hline ÂPLANOZ & 89,90 & 1,27 & 90,18 & 1,11 & $-0,75$ & 45 & 0,451597 \\
\hline ÂPLOCLUSAL & 89,34 & 1,74 & 89,64 & 2,62 & $-0,46$ & 45 & 0,642698 \\
\hline AिLANTEG & 88,63 & 1,51 & 89,35 & 2,40 & $-1,26$ & 45 & 0,211260 \\
\hline DESVENA & 1,33 & 0,84 & 1,19 & 0,90 & 0,51 & 45 & 0,608225 \\
\hline DESMAND & 2,71 & 1,63 & 2,37 & 2,15 & 0,60 & 45 & 0,546574 \\
\hline A1 & 1,40 & 0,90 & 2,12 & 1,51 & $-2,03$ & 45 & 0,047478 \\
\hline B1 & 1,58 & 0,97 & 2,10 & 1,48 & $-1,45$ & 45 & 0,153700 \\
\hline$\hat{\text { AANT }}$ & 2,40 & 1,51 & 3,12 & 2,81 & $-1,15$ & 45 & 0,254545 \\
\hline DISTZ & 1,77 & 1,24 & 2,21 & 1,36 & $-1,14$ & 45 & 0,260118 \\
\hline DISTCO & 3,20 & 2,42 & 3,25 & 2,54 & $-0,06$ & 45 & 0,947490 \\
\hline DISTZA & 2,86 & 1,96 & 3,10 & 2,58 & $-0,35$ & 45 & 0,722259 \\
\hline DISTNC & 2,51 & 1,57 & 2,74 & 2,01 & $-0,42$ & 45 & 0,673649 \\
\hline DISTJ & 2,47 & 1,65 & 2,75 & 2,21 & $-0,48$ & 45 & 0,629931 \\
\hline DISTAG & 4,25 & 3,19 & 2,95 & 2,91 & 1,37 & 45 & 0,176548 \\
\hline ALTA6 & 1,37 & 1,05 & 1,75 & 1,18 & $-1,14$ & 45 & 0,258694 \\
\hline COAG & 2,70 & 2,10 & 3,38 & 2,73 & $-0,95$ & 45 & 0,342229 \\
\hline COME & 2,26 & 2,21 & 2,38 & 2,65 & $-0,16$ & 45 & 0,866148 \\
\hline MEAG & 2,28 & 1,92 & 3,04 & 1,91 & $-1,30$ & 45 & 0,199982 \\
\hline
\end{tabular}


Resultados do teste $t$ independente, entre os grupos de oclusão normal e de Classe II, subdivisão, tratado com extrações de três pré-molares

(Grupo 3 x subgrupo B)

RADIOGRAFIA SUBMENTONIANA

TABEL A 36 - Sistema de Coordenadas Mandibulares

\section{ÂNTERO-POSTERIOR}

\begin{tabular}{l|c|c|c|c|c|c|c}
\hline \multirow{2}{*}{ VARIÁVEIS } & Média & D.P. & Média & D.P. & Valor t & gl & p \\
\cline { 2 - 9 } & $\begin{array}{c}\text { Oclusão } \\
\text { Normal }\end{array}$ & $\begin{array}{c}\text { Oclusão } \\
\text { Normal }\end{array}$ & $\begin{array}{c}\text { CI II, sub. } \\
\text { trat. 3PM }\end{array}$ & $\begin{array}{c}\text { CI II, sub. } \\
\text { trat. 3PM }\end{array}$ & & & \\
\hline GO-ETC & 1,21 & 1,22 & 1,54 & 1,11 & $-0,82$ & 41 & 0,411952 \\
\hline PPC-ETC & 1,32 & 0,85 & 2,12 & 1,32 & $-2,39$ & 41 & 0,021477 \\
\hline PDMI-ETC & 0,96 & 0,64 & 5,61 & 1,86 & $-12,25$ & 41 & 0,000000 \\
\hline PDMS-ETC & 0,96 & 0,72 & 1,40 & 1,29 & $-1,42$ & 41 & 0,161134 \\
\hline \multicolumn{7}{|c|}{ TRANSVERSAL } \\
\hline GO-EIC & 1,95 & 1,25 & 2,00 & 1,73 & $-0,09$ & 41 & 0,921301 \\
\hline PPC-EIC & 2,58 & 1,82 & 2,10 & 1,26 & 0,84 & 41 & 0,402052 \\
\hline PDMI-EIC & 2,94 & 2,04 & 3,64 & 2,76 & $-0,92$ & 41 & 0,358476 \\
\hline PDMS-EIC & 2,69 & 1,84 & 2,50 & 2,14 & 0,30 & 41 & 0,764896 \\
\hline LMM-EIC & 1,88 & 1,50 & 1,71 & 1,92 & 0,31 & 41 & 0,754580 \\
\hline LMDI-EIC & 1,72 & 1,24 & 1,76 & 1,68 & $-0,08$ & 41 & 0,934278 \\
\hline LMDS-EIC & 1,55 & 1,12 & 1,69 & 1,51 & $-0,32$ & 41 & 0,746247 \\
\hline
\end{tabular}

TABELA 37 - Sistema de Coordenadas do Assoalho Craniano

\section{ÁNTERO-POSTERIOR}

\begin{tabular}{l|c|c|c|c|c|c|c}
\hline \multirow{2}{*}{ VARIÁVEIS } & Média & D.P. & Média & D.P. & Valor t & gl & P \\
\cline { 2 - 9 } & $\begin{array}{l}\text { Oclusão } \\
\text { Normal }\end{array}$ & $\begin{array}{c}\text { Oclusão } \\
\text { Normal }\end{array}$ & $\begin{array}{c}\text { CI II, sub. } \\
\text { trat. 3PM }\end{array}$ & $\begin{array}{c}\text { CI II, sub. } \\
\text { trat. 3PM }\end{array}$ & & & \\
\hline PCM-ETE & 1,59 & 1,27 & 1,95 & 1,04 & $-0,88$ & 41 & 0,379875 \\
\hline GO-ETE & 1,63 & 1,42 & 2,41 & 1,84 & $-1,51$ & 41 & 0,136917 \\
\hline PPC-ETE & 1,68 & 1,28 & 2,38 & 1,64 & $-1,51$ & 41 & 0,136700 \\
\hline PDMI-ETE & 1,04 & 0,84 & 6,15 & 2,03 & $-11,73$ & 41 & 0,000000 \\
\hline PDMS-ETE & 1,02 & 0,90 & 1,50 & 1,12 & $-1,47$ & 41 & 0,146785 \\
\hline \multicolumn{7}{|c|}{ TRANSVERSAL } \\
\hline PCM-EIE & 0,95 & 0,68 & 1,36 & 1,01 & $-1,53$ & 41 & 0,131517 \\
\hline GO-EIE & 1,78 & 1,31 & 2,04 & 1,48 & $-0,57$ & 41 & 0,570443 \\
\hline PPC-EIE & 2,74 & 1,92 & 1,93 & 1,98 & 1,26 & 41 & 0,212185 \\
\hline PDMI-EIE & 3,26 & 2,41 & 4,31 & 2,85 & $-1,23$ & 41 & 0,222963 \\
\hline PDMS-EIE & 2,86 & 2,15 & 3,40 & 1,69 & $-0,80$ & 41 & 0,424917 \\
\hline LMM-EIE & 2,13 & 1,87 & 2,83 & 1,67 & $-1,15$ & 41 & 0,253958 \\
\hline LMDI-EIE & 1,90 & 1,67 & 2,53 & 1,44 & $-1,17$ & 41 & 0,245436 \\
\hline LMDS-EIE & 1,94 & 1,32 & 2,40 & 1,38 & $-1,03$ & 41 & 0,307001 \\
\hline
\end{tabular}


TABELA 38 - Sistema de Coordenadas Zigomaticomaxilares

\begin{tabular}{l|c|c|c|c|c|c|c}
\hline \multicolumn{8}{c}{ ÂNTERO-POSTERIOR } \\
\hline \multirow{2}{*}{ VARIÁVEIS } & Média & D.P. & Média & D.P. & Valor t & gl & p \\
\cline { 2 - 9 } & $\begin{array}{c}\text { Oclusão } \\
\text { Normal }\end{array}$ & $\begin{array}{c}\text { Oclusão } \\
\text { Normal }\end{array}$ & $\begin{array}{c}\text { CI II, sub. } \\
\text { trat. 3PM }\end{array}$ & $\begin{array}{c}\text { CI II, sub. } \\
\text { trat. 3PM }\end{array}$ & & & \\
\hline PDMI-ETPTM & $\mathbf{1 , 2 7}$ & $\mathbf{0 , 9 5}$ & $\mathbf{5 , 7 3}$ & $\mathbf{2 , 9 7}$ & $-\mathbf{7 , 4 7}$ & $\mathbf{4 1}$ & $\mathbf{0 , 0 0 0 0 0 0}$ \\
\hline PDMS-ETPTM & $\mathbf{1 , 2 3}$ & $\mathbf{0 , 9 0}$ & $\mathbf{2 , 2 7}$ & $\mathbf{1 , 4 3}$ & $\mathbf{- 2 , 8 8}$ & $\mathbf{4 1}$ & $\mathbf{0 , 0 0 6 2 7 5}$ \\
\hline \multicolumn{7}{|c|}{ TRANSVERSAL } \\
\hline VA-EIPTM & 1,08 & 0,72 & 1,37 & 1,24 & $-0,98$ & 41 & 0,329838 \\
\hline VP-EIPTM & 0,64 & 0,56 & 0,57 & 0,50 & 0,38 & 41 & 0,705138 \\
\hline PDMI-EIPTM & 2,52 & 2,66 & 3,06 & 2,75 & $-0,60$ & 41 & 0,547429 \\
\hline PDMS-EIPTM & 2,26 & 2,61 & 1,94 & 1,91 & 0,39 & 41 & 0,696608 \\
\hline LMDS-EIPTM & 1,82 & 1,85 & 2,21 & 1,33 & $-0,69$ & 41 & 0,493524 \\
\hline LMM-EIPTM & 1,94 & 1,92 & 2,03 & 1,54 & $-0,14$ & 41 & 0,885759 \\
\hline LMDI-EIPTM & 1,76 & 1,91 & 2,37 & 1,22 & $-1,05$ & 41 & 0,297731 \\
\hline
\end{tabular}

TABELA 39 - Sistema de Coordenadas Dentárias

\begin{tabular}{l|c|c|c|c|c|c|c}
\hline \multicolumn{9}{c}{ TRANSVERSAL } \\
\hline \multirow{2}{*}{ VARIÁVEIS } & Média & D.P. & Média & D.P. & Valor t & gl & p \\
\cline { 2 - 9 } & $\begin{array}{c}\text { Oclusão } \\
\text { Normal }\end{array}$ & $\begin{array}{c}\text { Oclusão } \\
\text { Normal }\end{array}$ & $\begin{array}{c}\text { CI II, sub. } \\
\text { trat. 3PM }\end{array}$ & $\begin{array}{l}\text { CI II, sub. } \\
\text { trat. 3PM }\end{array}$ & & & \\
\hline LMDI-EIMI & $\mathbf{0 , 6 3}$ & $\mathbf{0 , 5 2}$ & $\mathbf{6 , 0 6}$ & $\mathbf{1 , 1 6}$ & $-21,26$ & 41 & $\mathbf{0 , 0 0 0 0 0 0}$ \\
\hline LMM-EIMI & $\mathbf{0 , 8 8}$ & $\mathbf{0 , 6 8}$ & $\mathbf{4 , 5 4}$ & $\mathbf{1 , 4 9}$ & $-11,13$ & 41 & 0,000000 \\
\hline LMDS-EIMI & $\mathbf{0 , 7 3}$ & $\mathbf{0 , 4 9}$ & $\mathbf{6 , 1 6}$ & $\mathbf{1 , 2 1}$ & $-\mathbf{2 1 , 0 7}$ & $\mathbf{4 1}$ & $\mathbf{0 , 0 0 0 0 0 0}$ \\
\hline LMDI-EIMS & 0,62 & 0,52 & 0,76 & 0,53 & $-0,77$ & 41 & 0,444136 \\
\hline LMDS-EIMS & 0,55 & 0,47 & 0,66 & 0,54 & $-0,70$ & 41 & 0,483773 \\
\hline LMM-EIMS & 0,89 & 0,74 & 1,37 & 1,11 & $-1,66$ & 41 & 0,103075 \\
\hline
\end{tabular}

TABELA 40 - Medidas Angulares

\begin{tabular}{l|c|c|c|c|c|c|c}
\hline \multirow{2}{*}{ VARIÁVEIS } & Média & D.P. & Média & D.P. & Valor t & gl & p \\
\cline { 2 - 8 } & $\begin{array}{c}\text { Oclusão } \\
\text { Normal }\end{array}$ & $\begin{array}{c}\text { Oclusão } \\
\text { Normal }\end{array}$ & $\begin{array}{c}\text { CI II, sub. } \\
\text { trat. 3PM }\end{array}$ & $\begin{array}{c}\text { CI II, sub. } \\
\text { trat. 3PM }\end{array}$ & & & \\
\hline EIE.EIC & 0,81 & 0,64 & 0,98 & 0,62 & $-0,82$ & 41 & 0,414498 \\
\hline ETE.ETC & 0,84 & 0,65 & 1,05 & 0,56 & $-0,99$ & 41 & 0,327414 \\
\hline ETPTM.ETC & 1,23 & 0,84 & 1,27 & 1,19 & $-0,14$ & 41 & 0,883878 \\
\hline ETPTM.ETE & 1,46 & 1,02 & 1,49 & 1,15 & $-0,08$ & 41 & 0,935053 \\
\hline ETMI.ETE & $\mathbf{1 , 0 9}$ & $\mathbf{0 , 8 7}$ & $\mathbf{6 , 7 0}$ & $\mathbf{2 , 1 7}$ & $-\mathbf{- 1 2 , 1 8}$ & 41 & 0,000000 \\
\hline ETMI.ETC & $\mathbf{1 , 0 2}$ & $\mathbf{0 , 6 7}$ & $\mathbf{6 , 1 4}$ & $\mathbf{1 , 8 9}$ & $\mathbf{- 1 3 , 1 4}$ & $\mathbf{4 1}$ & $\mathbf{0 , 0 0 0 0 0 0}$ \\
\hline ETMI.ETPTM & $\mathbf{1 , 3 8}$ & $\mathbf{1 , 0 4}$ & $\mathbf{6 , 2 5}$ & $\mathbf{3 , 2 2}$ & $-\mathbf{7 , 5 1}$ & 41 & $\mathbf{0 , 0 0 0 0 0 0}$ \\
\hline ETMS.ETE & 1,04 & 0,92 & 1,62 & 1,24 & $-1,68$ & 41 & 0,099595 \\
\hline ETMS.ETC & 1,00 & 0,76 & 1,50 & 1,36 & $-1,56$ & 41 & 0,126279 \\
\hline ETMS.ETPTM & $\mathbf{1 , 2 7}$ & $\mathbf{0 , 9 7}$ & $\mathbf{2 , 4 5}$ & $\mathbf{1 , 5 0}$ & $-3,06$ & 41 & $\mathbf{0 , 0 0 3 8 3 8}$ \\
\hline
\end{tabular}


TABELA 41 - Variáveis Adicionais

\begin{tabular}{l|c|c|c|c|c|c|c}
\hline \multirow{2}{*}{ VARIÁVEIS } & Média & D.P. & Média & D.P. & Valor t & gl & p \\
\cline { 2 - 9 } & $\begin{array}{c}\text { Oclusão } \\
\text { Normal }\end{array}$ & $\begin{array}{c}\text { Oclusão } \\
\text { Normal }\end{array}$ & $\begin{array}{c}\text { CI II, sub. } \\
\text { trat. 3PM }\end{array}$ & $\begin{array}{c}\text { CI II, sub. } \\
\text { trat. 3PM }\end{array}$ & & & \\
\hline PCM-LMM & 1,77 & 1,53 & 1,83 & 2,03 & $-0,10$ & 41 & 0,919389 \\
\hline PCM-CMM & 2,25 & 1,49 & 1,83 & 1,38 & 0,85 & 41 & 0,397123 \\
\hline POSM & 1,46 & 1,07 & 1,70 & 1,16 & $-0,65$ & 41 & 0,513211 \\
\hline POSMS & 1,69 & 1,16 & 1,70 & 0,85 & $-0,00$ & 41 & 0,992652 \\
\hline
\end{tabular}

TABELA 42 - RADIOGRAFIA PÓSTERO-ANTERIOR

\begin{tabular}{l|c|c|c|c|c|c|c}
\multirow{4}{*}{ VARIÁVEIS } & Média & D.P. & Média & D.P. & Valor t & gl & p \\
\cline { 2 - 8 } & $\begin{array}{c}\text { Oclusão } \\
\text { Normal }\end{array}$ & $\begin{array}{c}\text { Oclusão } \\
\text { Normal }\end{array}$ & $\begin{array}{c}\text { CI II, sub. } \\
\text { trat. 3PM }\end{array}$ & $\begin{array}{c}\text { CI II, sub. } \\
\text { trat. 3PM }\end{array}$ & & & \\
\hline ÂPLANOZ & 89,90 & 1,27 & 89,86 & 1,59 & 0,09 & 41 & 0,921812 \\
\hline$\hat{\text { ÂPLOCLUSAL }}$ & 89,34 & 1,74 & 89,83 & 2,51 & $-0,73$ & 41 & 0,467838 \\
\hline$\hat{\text { ÂPLANTEG }}$ & 88,63 & 1,51 & 89,12 & 2,71 & $-0,76$ & 41 & 0,449411 \\
\hline DESVENA & 1,33 & 0,84 & 1,21 & 0,94 & 0,39 & 41 & 0,695032 \\
\hline DESMAND & 2,71 & 1,63 & 2,27 & 1,33 & 0,83 & 41 & 0,407108 \\
\hline A1 & 1,40 & 0,90 & 1,66 & 1,56 & $-0,67$ & 41 & 0,503834 \\
\hline B1 & 1,58 & 0,97 & 1,93 & 1,83 & $-0,83$ & 41 & 0,406056 \\
\hline AANT & 2,40 & 1,51 & 3,01 & 1,68 & $-1,17$ & 41 & 0,245271 \\
\hline DISTZ & 1,77 & 1,24 & 1,81 & 1,86 & $-0,09$ & 41 & 0,925702 \\
\hline DISTCO & 3,20 & 2,42 & 3,30 & 3,13 & $-0,10$ & 41 & 0,913147 \\
\hline DISTZA & 2,86 & 1,96 & 2,82 & 3,07 & 0,04 & 41 & 0,962429 \\
\hline DISTNC & 2,51 & 1,57 & 2,29 & 1,62 & 0,42 & 41 & 0,673326 \\
\hline DISTJ & 2,47 & 1,65 & 2,69 & 1,63 & $-0,39$ & 41 & 0,696361 \\
\hline DISTAG & 4,25 & 3,19 & 4,50 & 2,70 & $-0,25$ & 41 & 0,801023 \\
\hline ALTA6 & 1,37 & 1,05 & 2,06 & 1,40 & $-1,76$ & 41 & 0,084299 \\
\hline CO-AG & 2,70 & 2,10 & 2,93 & 3,27 & $-0,28$ & 41 & 0,778813 \\
\hline CO-ME & 2,26 & 2,21 & 3,13 & 2,51 & $-1,13$ & 41 & 0,261703 \\
\hline ME-AG & 2,28 & 1,92 & 3,73 & 3,66 & $-1,70$ & 41 & 0,096176 \\
\hline
\end{tabular}




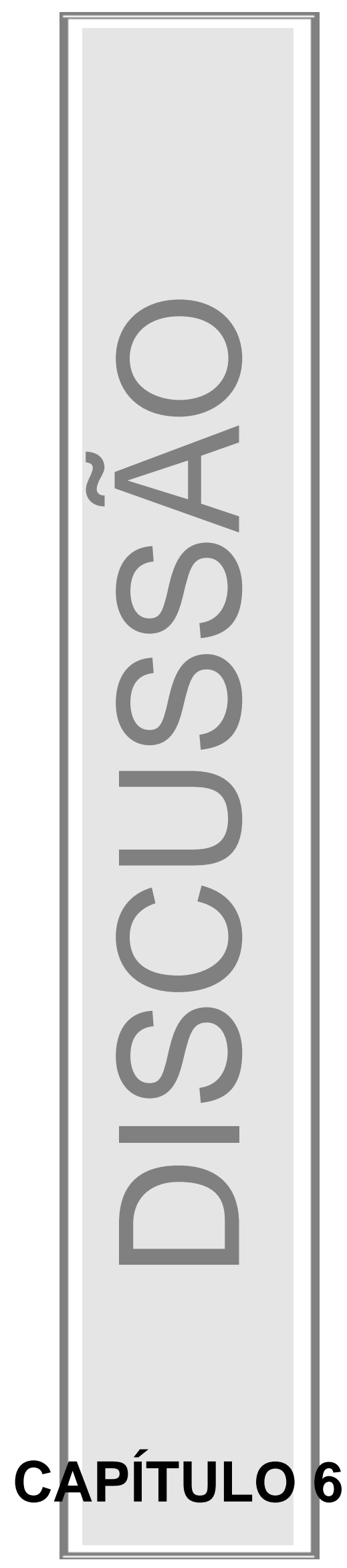




\section{6 - DISCUSSÃO}

om 0 intuito de facilitar o entendimento e a interpretação dos
resultados alcançados neste trabalho, serão discutidos inicialmente os aspectos referentes à amostra e `a metodologia empregadas. Posteriormente, serão realizadas considerações pertinentes à mensuração das grandezas cefalométricas, sobre a precisão da metodologia e a interpretação dos resultados obtidos nas radiografias submentoniana e póstero-anterior. Ao final, algumas considerações clínicas serão efetuadas quanto às alterações dentoesqueléticas decorrentes do tratamento da Classe II, subdivisão.

\section{1 - Amostra Selecionada}

Alguns critérios já citados no capítulo de Material e Métodos foram adotados para a seleção da amostra. A avaliação da presença destes critérios foi realizada pela investigadora, por meio de exame clínico e anamnese. Como regra geral, todos os pacientes pertencentes ao grupo experimental, previamente ao tratamento, e ao grupo de oclusão normal deveriam apresentar todos os dentes permanentes superiores e inferiores, em ambos os arcos dentários, até os primeiros molares ${ }^{1,73,88,98,137,151}$. Assim, eliminaram-se possíveis movimentações dentárias que ocasionariam desarranjos no relacionamento dos dentes e influenciariam o aparecimento de assimetrias dentárias ${ }^{73}$. Este procedimento foi adotado, pois já se demonstrou que mutilações nos arcos dentários e ausência de dentes, durante o desenvolvimento mandibular, podem provocar uma assimetria esquelética ${ }^{7,138} \mathrm{e}$ uma remodelação condilar ${ }^{109}$.

O grupo experimental, previamente ao tratamento, consistiu de pacientes que apresentavam relação molar de Classe II completa unilateral e de Classe I do lado oposto, detectada por meio de exame clínico. Alguns critérios adicionais foram implementados na seleção destes pacientes, anteriormente ao tratamento. Convencionou-se que estes jovens não deveriam ter sido submetidos a tratamento ortodôntico, pois assim poderiam mascarar o verdadeiro relacionamento dos dentes com as bases apicais ${ }^{73,94,98,137}$. 
Considerou-se que o deslocamento mandibular lateral durante o fechamento bucal, detectado durante o exame clínico deveria estar ausente 1,73,98,116,137,145,151. Este pré-requisito baseou-se nos trabalhos de WILLIAMSON ${ }^{178}$ e SLAVICEK $^{161}$ que asseguravam que a presença de um deslocamento mandibular lateral devido a algum contato prematuro, causa uma alteração da relação ântero-posterior do lado contrário ao desvio, ocasionando um diagnóstico errôneo da oclusão daquele lado. Este critério concordou com os pensamentos de SHROFF; SIEGEL ${ }^{155}$ que afirmavam que "as assimetrias resultantes de desvios funcionais mandibulares geralmente decorrem de contatos prematuros em cêntrica, causando um desvio mandibular lateral na máxima intercuspidação habitual".

A ausência de histórico de trauma facial ou condições médicas que poderiam ter alterado o crescimento das bases apicais ${ }^{73,98,132,137}$ foi adotada como outro prérequisito para a seleção da amostra, pois já se demonstrou que as respostas compensatórias a uma injúria podem induzir um desequilíbrio no crescimento do côndilo e do ramo como um todo ${ }^{6,39,40}$ e já se constatou que há uma associação entre o trauma e o crescimento assimétrico da mandíbula $85,132,155,159,160,166,185$.

O apinhamento não deveria exceder três milímetros nos arcos dentários superior e/ou inferior, nos casos de Classe II, subdivisão. Entretanto, este apinhamento deveria ser simétrico, pois assim não ocasionaria as assimetrias dentoalveolares evidentes, decorrentes de problemas de falta de espaço em um quadrante. Permitiurse a presença deste pequeno apinhamento porque as más oclusões sem nenhum apinhamento são difíceis de serem encontradas ${ }^{1,73,97}$.

Os pacientes que se submeteram ao tratamento ortodôntico apresentavam, inicialmente, uma má oclusão de Classe II, devido a uma posição mais mesial do molar superior ou devido a uma posição mais distal do molar inferior do lado da Classe $\|^{1,73,137}$. Portanto, de acordo com a etiologia desta má oclusão, foram considerados dois tipos de terapêutica assimétrica. Realizou-se a extração de um pré-molar superior do lado da Classe II, nos casos de em que o molar superior situava-se mais para mesial deste mesmo lado, com desvio da linha média dentária 
superior em sentido contrário ao lado da Classe II e coincidência da linha média dentária inferior em relação ao plano sagital mediano. As extrações de dois prémolares superiores e um pré-molar inferior do lado da Classe I foram realizadas nos casos do molar inferior situado mais distalmente, no lado da Classe II e, concomitante, desvio da linha média dentária inferior para este lado, além da linha média dentária superior se apresentar coincidente em relação ao plano sagital mediano. Portanto, neste aspecto, a amostra não se apresentava totalmente uniforme. Deste modo, este grupo foi dividido em dois subgrupos para auxiliar na interpretação dos resultados. O ideal, evidentemente, seria uma amostra totalmente uniforme quanto à sistemática das extrações. Entretanto, como estes protocolos de extrações não eram tão freqüentes anteriormente e que só recentemente passaram a ser mais utilizados, não foi possível encontrar um número estatisticamente satisfatório de casos bem terminados, com apenas um dos protocolos de extrações.

Quanto ao gênero, não houve problemas referentes à falta de proporcionalidade entre os sexos masculino e feminino nos dois grupos estudados, visto que ARNOLD; ANDERSON; LILYEMARK ${ }^{5}$, ao estabelecerem padrões de normalidade nas radiografias submentonianas, não verificaram diferenças estatisticamente significantes entre os sexos, quanto às assimetrias. MELNIK ${ }^{101}$ corroborou com esta conclusão quando avaliou as assimetrias por meio de radiografias oblíquas a $45^{\circ}$ em pacientes de ambos os sexos, acima de 14 anos de idade. Realizando medições diretas em mandíbulas de crânios europeus de séculos passados, PONYI; SZABÓ; NYILASI ${ }^{29}$, também não detectaram diferenças significantes entre os sexos. Da mesma maneira, CHEBIB; CHAMMA ${ }^{31}$ estudando índices de assimetria craniofacial em cefalogramas póstero-anteriores, e SHEATS et al. ${ }^{153}$, pesquisando sobre a prevalência da assimetria dentária e facial em escolares americanos de ambos os sexos, não verificaram uma associação entre o gênero e a assimetria.

Com relação às idades entre os grupos, verificou-se que os grupos de Classe II, subdivisão tratado e de oclusão normal apresentavam idades médias de 18,57 e 22,42 anos, respectivamente. Considerou-se esta diferença desprezível para os 
pacientes do sexo feminino, pois nesta faixa etária, a maior parte da maturação já tinha ocorrido. Quanto aos pacientes do sexo masculino, verificou-se que sua maturação estava quase completa. Além disso, MELNIK ${ }^{101}$ estudando a assimetria mandibular, verificou que existe uma probabilidade semelhante de ocorrer uma acentuação ou diminuição desta assimetria com o crescimento, podendo-se, dentro de certos limites, fazer uma analogia em relação ao crescimento craniofacial, de uma forma geral. Desta maneira, a diferença de idade entre os grupos não interferiu na avaliação.

\section{2 - Metodologia Empregada}

As radiografias submentonianas e póstero-anteriores foram obtidas em máxima intercuspidação habitual de acordo com LAM; SADOWSKY; OMERZA ${ }^{84}$ (1999), MONGINI; SCHMID ${ }^{110}$ (1987), O'BYRN et al. ${ }^{116}$ (1995), SCHMID; MONGINI; FELISIO $^{145}$ (1991), SHAH; JOSHI ${ }^{151}$ (1978). De modo contrário, FORSBERG; BURSTONE; HANLEY ${ }^{46}$ (1984), RITUCCI; BURSTONE ${ }^{136}$ (1981), WILLIAMSON ${ }^{177}$ (1981), WILLIAMSON; SIMMONS ${ }^{179}$ (1979), WILLIAMSON; WILSON ${ }^{180}$ (1976) recomendam sua obtenção em relação cêntrica quando se deseja detectar qualquer desvio mandibular funcional que possa interferir na avaliação da assimetria mandibular, em relação à maxila e à base do crânio. Isto se aplica, principalmente, aos casos de Classe II, pois estes geralmente apresentam um maior desvio, para anterior, que aqueles com Classe $1^{133}$. Entretanto, neste trabalho, um dos critérios adotados no momento da seleção da amostra consistiu na ausência de desvio funcional mandibular lateral em todos os pacientes ${ }^{1,73,98,116,137,151}$. Desta forma, objetivourse uma maior precisão na correta avaliação da assimetria mandibular, em relação à maxila e à base do crânio $^{73}$. Baseando-se nos princípios de DAWSON ${ }^{38}$ (1974) e OKESON ${ }^{119}$ (1989), adotourse a manipulação bilateral da mandíbula em relação cêntrica para a avaliação de qualquer desvio funcional mandibular. Considerou-se este tipo de manipulação suficiente para levar os côndilos em relação cêntrica, desde que os pacientes não apresentassem nenhum sintoma de distúrbios temporomandibulares ${ }^{139}$. 
Como já mencionado anteriormente neste trabalho, no capítulo de Material e Métodos, utilizaram-se valores absolutos, visando eliminar a possibilidade de que os valores de diferença, positivos ou negativos se cancelassem no cálculo das médias para cada grupo ${ }^{5}$. Também, realizou-se este procedimento devido ao fato de que pacientes que não apresentam assimetria facial ou dentária evidentes, demonstram diferenças esqueléticas de tamanho entre os lados direito e esquerdo da maxila e da mandíbula ${ }^{151,172}$. Além disso, MELNIK ${ }^{101}$ demonstrou que a mandíbula se apresenta assimétrica em jovens em crescimento, em diferentes idades. Ainda mais, pesquisas ${ }^{56,95}$ demonstraram que mesmo em pacientes com oclusão normal, existia um certo grau de assimetria presente no arco dentário. Para completar este pensamento, de acordo com algumas teorias de assimetria direcional| $\left.\right|^{31,122,124,125,129,172,182}$, verificaram-se desvios dentários ou esqueléticos, predominantemente para um dos lados. Portanto, se os valores reais fossem utilizados, os grupos poderiam apresentar uma assimetria direcional que influiria nos resultados obtidos, levando a conclusões distorcidas ${ }^{73}$.

\section{3 - Considerações sobre a Mensuração das Grandezas Cefalométricas}

Com o surgimento da informática, a ciência e a tecnologia puderam evoluir em todos os campos de atuação. Aproveitando-se deste recurso, recorreutse à utilização do computador para a medição das grandezas cefalométricas, trabalhando-se com um maior número de dados em um menor período de tempo. programa Dentofacial Planner 7.0, disponível na Disciplina de Ortodontia, proporcionou a medição com precisão de $0,1 \mathrm{~mm}$ ou $0,1 \mathrm{grau}$, tendo sido já utilizado em diversos trabalhos, assegurando sua fidedignidade ${ }^{16,20,28,73,74,93,117,118,120,128,162,170}$. Permitiu, também, a exportação dos resultados obtidos para um programa de estatística, garantindo uma maior precisão na transferência de dados de um programa para outro. Portanto, o método manual seria menos prático, não só por ser mais lenta a obtenção dos valores das variáveis, como também haveria uma maior possibilidade de erros durante a manipulação dos dados. Deste modo, a utilização do método computadorizado facilitou o trabalho, além de diminuir a possibilidade de erros na fase de mensuração das medidas cefalométricas ${ }^{135}$. 
Nesta pesquisa foram utilizadas 145 variáveis no total, sendo 34 variáveis ímpares e 37 pares, representando, na verdade, 74 variáveis referentes aos lados direito e esquerdo de cada paciente, sendo somente utilizadas as diferenças entre as mesmas. Desta forma, no sumário dos resultados nas tabelas analisadas, somente 71 variáveis podem ser vistas.

\section{4 - Precisão da Metodologia}

Os traçados anatômicos, a demarcação dos pontos e, posteriormente, sua digitalização, foram realizados duas vezes para dez pacientes $\left(\mathrm{HOUSTON}^{66}\right.$ ), objetivando-se avaliar a precisão e a reprodutibilidade da investigadora. Desta maneira, neste estudo, selecionaram-se, aleatoriamente, dez radiografias submentonianas e dez póstero-anteriores, totalizando-se 20 radiografias da amostra geral, para se calcular os erros casuais e sistemáticos.

Em se tratando dos erros casuais (DAHLBERG ${ }^{37}$ ), verificou-se pelas tabelas 8 a 14 que os maiores valores foram referentes às variáveis do sistema de coordenadas zigomaticomaxilares, na radiografia submentoniana, em consonância com o trabalho de JANSON $^{73}$. A maior magnitude destes erros pode ser justificada pelo fato dos pontos mais mediais e posteriores de cada fissura pterigomaxilar serem de difícil visualização nesta radiografia conforme já mencionado por ROSE et al. ${ }^{137}$, LEW; TAY ${ }^{88}$ e O'BYRN et al. ${ }^{116}$ que utilizaram a radiografia submentoniana e não avaliaram estruturas da maxila. Segundo HOUSTON ${ }^{66}$, os erros casuais advêm das dificuldades na identificação dos pontos cefalométricos e também devido à imprecisão nas definições de certos pontos. A situação ideal é aquela em que a média das diferenças iguala-se a zero, para uma determinada medida cefalométrica repetida numa série de cefalogramas duplicados, pois isto indica que os erros casuais ocorreram de modo equilibrado nos dois sentidos, isto é, tanto para mais como para menos. Por outro lado, caso a média das diferenças seja diferente de zero, talvez tenha havido uma tendência ao direcionamento dos resultados, de modo consciente ou inconsciente, seja subestimando-os ou superestimando-os, reiteradamente $^{143}$. Na radiografia póstero-anterior, 13 variáveis mostraram valores de magnitude acima de $1 \mathrm{~mm}$, entretanto estes erros não afetaram a precisão das 
medidas realizadas. Desde que haja um equilíbrio entre os valores subestimados e os superestimados, as médias obtidas no erro sistemático não são afetadas, conforme pode ser verificado pela ausência de significância estatística na avaliação destas variáveis pelo teste $t$ pareado ${ }^{73,143}$.

Com relação à análise dos erros sistemáticos ${ }^{9,52,66,135}$, para 0 teste $\mathrm{t}$ dependente (tabelas 8 a 14), percebe-se que somente cinco variáveis apresentaram significância estatística, na radiografia submentoniana e uma variável, para a radiografia $\mathrm{PA}$. Percebe-se que as variáveis que demonstraram diferenças significantes entre os pares dos traçados repetidos consistiram de estruturas de difícil visualização e padronização ${ }^{73}$. Desta forma, no sistema de coordenadas mandibulares, duas variáveis apresentaram diferença estatisticamente significante. A primeira variável consistiu do ponto distal do molar superior ao eixo transcondilar, para o sentido ântero-posterior (PDMS-ETC) e a segunda variável foi a linha média dentária inferior ao eixo intercondilar (LMDLEIC), para o sentido transverso deste mesmo sistema de coordenadas (tabela 8). Entretanto, apesar destas variáveis apresentaram diferenças estatisticamente significantes $(p<0,05)$, constituíram-se em valores isolados, apresentando médias muito próximas ao normal. A concentração maior de diferenças ocorreu com as três variáveis pertencentes ao sistema de coordenadas zigomaticomaxilares, sendo a linha média dentária superior, a linha média mandibular e a linha média dentária inferior ao eixo interpterigomaxilar (LMDS-EIPTM, LMM-EIPTM, LMDHEIPTM - tabela 10). A justificativa para estas diferenças deveu-se aos pontos que originam o eixo transpterigomaxilar e, conseqüentemente, o eixo interpterigomaxilar uma vez que as estruturas mais mediais e posteriores de cada fissura pterigomaxilar apresentam visualização reduzida $^{73}$. Para a radiografia $P A$, a única variável que apresentou diferença estatisticamente significante foi o ângulo do plano antegoniano (ÂPLANTEG - tabela 14). Esta variável refere-se ao ponto situado na chanfradura antegoniana cuja localização apresenta grande dificuldade na visualização frontal. 


\section{5 - Resultados Obtidos nas Radiografias Submentonianas}

Baseando-se na metodologia dos trabalhos de JANSON ${ }^{73}$ e ROSE et al. ${ }^{137}$, utilizourse a análise de RITUCCI; BURSTONE ${ }^{46,136}$, também nesta pesquisa, objetivando avaliar a assimetria das estruturas dentoesqueléticas em relação aos sistemas de coordenadas da mandíbula, do assoalho craniano, do complexo zigomaticomaxilar, complementando-se com as variáveis adicionais. Adicionou-se à avaliação das assimetrias o sistema de coordenadas dentárias e as avaliações angulares entre as abscissas dos três sistemas de coordenadas da análise de RITUCCI; BURSTONE ${ }^{136}$, de acordo com ROSE et al. ${ }^{137}$, acrescidas ainda das avaliações das abscissas dentárias em relação às outras abscissas mencionadas. Desta forma, objetivou-se conseguir um maior número possível de informações em relação às características do grupo de Classe II, subdivisão tratado, para comparação com o grupo de oclusão normal. Esta análise, bastante citada na literatura $^{46,136}$, utiliza os forames espinhosos para estabelecer o eixo sagital de simetria da base do crânio, pois se constituem em estruturas de grande estabilidade, fácil localização e boa reprodutibilidade ${ }^{96}$. Apesar de nenhum ponto cefalométrico ser imutável, estas estruturas apresentam grande estabilidade e fácil localização.

Estudando as radiografias submentonianas, GILBERT ${ }^{51}$ relatou erros significantes em medidas ântero-posteriores e precisão nas medidas transversais. Apesar desta contradição, a avaliação do tamanho das estruturas durante a realização dos traçados não foi afetada, pois neste trabalho, as avaliações foram referentes às diferenças entre os dois lados, que sofreram a mesma distorção.

A discussão dos resultados obtidos da comparação das assimetrias dentoesqueléticas do grupo 2 e dos subgrupos $A$ e $B$ com o grupo de oclusão normal foi conduzida, tendo-se em mente as assimetrias que os casos de Classe II, subdivisão apresentavam antes do tratamento $\left(\right.$ JANSON $\left.^{73}\right)$, e que estão dispostos nas tabelas 15 a 21 . 


\subsection{1 - Sistema de Coordenadas Mandibulares}

Verificou-se que houve uma diferença significante para a variável PPC-ETC, na tabela $36(p<0,05)$, sugerindo uma suave assimetria esquelética do processo coronóide mandibular no subgrupo $B$, após o tratamento. É pouco provável que a forma de tratamento utilizada possa ter influenciado o aparecimento dessa assimetria, que não estava presente no grupo inicialmente (tabela 15). Essa diferença nesse grupo pode ser atribuída a uma característica inerente neste subgrupo, uma vez que os pacientes não eram os mesmos que foram avaliados antes do tratamento.

Analisando as tabelas de números 15, 22, 29 e 36, verificourse que as variáveis que se apresentaram estatisticamente diferentes foram as referentes às posições ântero-posteriores dos molares inferiores e superiores, em relação à posição do eixo transcondilar (PDMLETC e PDMS-ETC). Entretanto, estas variáveis apresentaram um comportamento diferente nestas tabelas, já que se referem aos resultados entre os grupos de oclusão normal (grupo 3) com os seguintes grupos: má oclusão de Classe II, subdivisão, não tratado (grupo 1 - tabela 15); má oclusão de Classe II, subdivisão tratado (grupo 2 - tabela 22); má oclusão tratado com extração de um pré-molar superior (subgrupo A - tabela 29) e má oclusão tratado com extrações de três pré-molares (subgrupo B - tabela 36) (figura 6.1).

Pôde-se perceber que, na tabela 22, a diferença manifestourse mais fortemente na posição ântero-posterior dos molares inferiores (PDMLETC), sendo facilmente visualizada pelo aumento das médias ao final do tratamento. Convém lembrar que o grupo experimental, constituiurse de uma combinação de duas modalidades de tratamento distintas. Isto ocorreu devido à presença de casos tratados com extrações de três pré-molares, constando de 13 pacientes (subgrupo $B$ - tabela 36), que se submeteram à extração de dois primeiros pré-molares superiores e do primeiro pré-molar inferior do lado da Classe I. Portanto, a terapêutica, destes casos, contribuiu para que houvesse até um aumento da diferença entre os pontos distais dos molares inferiores ao eixo transcondilar, em comparação ao resultado apresentado pelo grupo 1 com o grupo de oclusão normal. 
Raciocínio semelhante aplica-se para explicar a diferença para a variável PDMSETC (tabela 22). A presença de casos tratados somente com a extração de um prémolar superior (subgrupo A - tabela 29) contribuiu para a permanência da diferença que já existia entre os grupos de oclusão normal e de Classe II subdivisão, antes do tratamento (tabela 15). Isto era esperado pelos dois tipos de tratamento a que foram submetidos os pacientes. Como já mencionado, o ideal seria ter escolhido um grupo maior, que tivesse sido submetido a somente uma das abordagens terapêuticas. Entretanto, a inclusão aleatória destas duas formas de tratamento decorre das características que são normalmente encontradas em grupos de Classe II selecionados aleatoriamente. O mesmo raciocínio poderia ter sido aplicado quando foram selecionados grupos de Classe II subdivisão não tratados, para comparação com grupos de oclusão normal, em pesquisas anteriores ${ }^{1,73,137}$. Ou seja, escolher os casos de Classe II subdivisão, causados por uma posição mais para distal do molar inferior de um dos lados (que estabeleceria a Classe II), ou por uma posição mais mesial do molar superior de um dos lados (que causaria a Classe II). Logicamente isto não foi realizado porque, no início, não se conhecia exatamente a natureza da Classe II, subdivisão. Portanto, o presente trabalho, talvez o primeiro que realizou este tipo de investigação nas radiografias submentoniana e póstero-anterior, poderá fornecer subsídios para futuras investigações mais específicas.

Analisando mais detalhadamente os subgrupos de acordo com os diferentes protocolos de extração, percebeurse que a variável PDMI-ETC (tabela 29) apresentou uma diferença estatisticamente significante, sugerindo que mesmo quando a Classe II, subdivisão é provocada pela posição mais mesial do molar superior de um lado, ainda há participação de diferenças de posição ântero-posterior entre os molares inferiores. A variável PDMS-ETC (tabela 29) apresentou uma diferença significante e em valores absolutos, a diferença entre os molares superiores, ao final do tratamento, neste grupo (4,42 - tabela 29), foi maior do que o do grupo de má oclusão de Classe II, previamente ao tratamento (1,48 - tabela 15). Esta diferença era esperada uma vez que houve extração de apenas um pré-molar superior para a correção da Classe II de canino e da linha média superior. Os primeiros molares superiores sofreram uma mesialização devido à extração do 
primeiro pré-molar do lado da Classe II, terminando-se os casos com uma relação de Classe II deste lado, mas com as linhas médias coincidentes entre si e com o plano sagital mediano. Entretanto, esta maior diferença entre as posições ânteroposteriores dos primeiros molares superiores após o tratamento, em relação ao início ocorreu justamente porque o grupo de Classe II, subdivisão não tratado era constituído de casos com diferentes etiologias, ou seja, parte era devido a uma posição mais para distal do molar inferior de um dos lados (que estabeleceria a Classe II), e outra parte decorrente da posição mais para mesial do molar superior de um dos lados (que causaria a Classe II), sem excluir evidentemente algum caso que apresentasse uma combinação das duas características. Se as características de um grupo de Classe II, subdivisão, ocasionado por uma posição mais mesial do molar superior de um dos lados, previamente ao tratamento fossem comparadas com esse mesmo grupo, após o tratamento, com extração de um pré-molar superior do lado da Classe II, o comportamento desta variável em relação ao grupo de oclusão normal seria praticamente o mesmo.

$\mathrm{Na}$ tabela 36, a variável PDMI-ETC, apresentou uma diferença estatisticamente significante entre os grupos de Classe II, subdivisão, tratado com extrações de três pré-molares e o de oclusão normal. Isto ocorreu devido a uma maior mesialização dos molares inferiores conseqüente à extração do primeiro prémolar inferior do lado da Classe I, para a correção do desvio da linha média inferior, nesta direção. Analogamente ao caso anterior, este resultado também era lógico e esperado. A variável PDMS-ETC não expressou diferença estatisticamente significante visto que foram realizadas extrações bilaterais simétricas no arco dentário superior devido à ausência de desvio de linha média superior que estes casos de Classe II, subdivisão, causados por uma posição mais para distal do molar inferior do lado da Classe II, geralmente apresentam. Diferentemente do que ocorreu com o subgrupo anterior, esta ausência de diferença estatística para esta variável demonstra que a participação de uma posição assimétrica dos primeiros molares superiores na Classe II, subdivisão é menos freqüente, como já salientado em trabalhos anteriores ${ }^{1,73}$. Isto demonstra que estes casos foram corretamente diagnosticados porque a linha média dentária superior estava coincidente com o 
plano sagital mediano no início do tratamento e permaneceu coincidente após a finalização dos casos. Interessante é interpretar o resultado obtido quando foram comparados o grupo de oclusão normal com o de Classe II, subdivisão, previamente ao tratamento, com relação ao comportamento destas variáveis (PDMLETC e PDMS-ETC - tabela 15). Houve diferenças estatisticamente significantes para estas duas variáveis porque esse grupo era composto por casos de Classe II com os dois tipos de etiologia anteriormente mencionados.

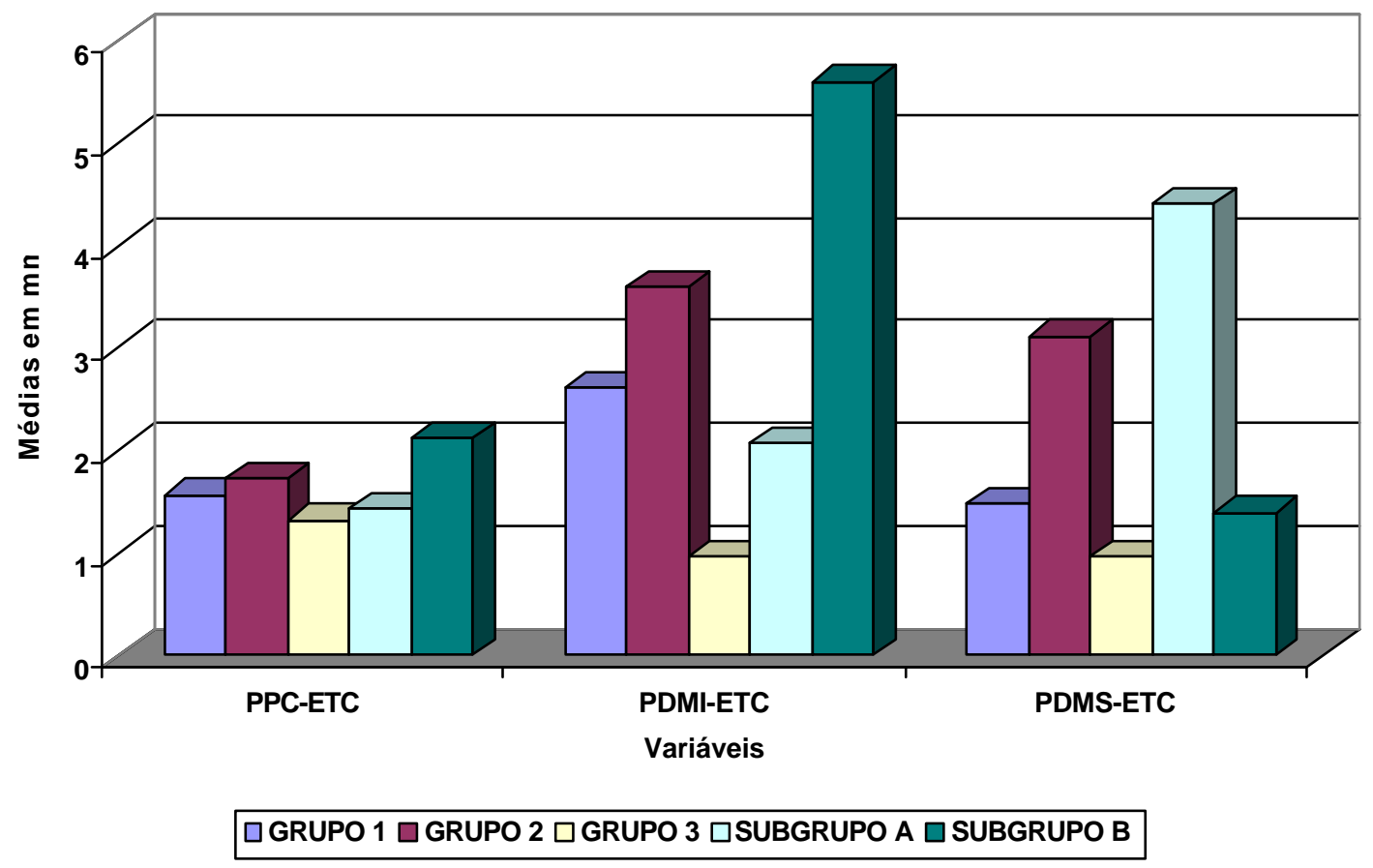

FIGURA 6.1 - Médias das variáveis que apresentaram diferenças estatisticamente significantes no sistema de coordenadas mandibulares, no sentido ântero-posterior

De forma geral, no sentido transversal do sistema de coordenadas mandibulares, a mecânica empregada, independentemente do tipo de planejamento assimétrico realizado, não afetou as variáveis, em relação ao eixo intercondilar. 


\subsection{2 - Sistema de Coordenadas do Assoalho Craniano}

Neste sistema de coordenadas, para a medição das diversas estruturas dentárias e esqueléticas, adotaram-se como parâmetro os forames espinhosos, baseando-se nos trabalhos de MOSS; SALENTIJN ${ }^{112}$ que demonstraram que a passagem e a localização dos feixes neuromusculares, durante o crescimento, não podem ser violadas. Várias outras pesquisas seguiram esta linha de pensamento, como o de MARMARY; ZILBERMAN; MIRSKY ${ }^{96}$ que utilizaram a bissetriz perpendicular de uma linha unindo os dois forames espinhosos com a linha média craniana. Estes estudos, juntamente com os publicados por FORSBERG; BURSTONE; HANLEY ${ }^{46}$ e JANSON ${ }^{73}$, contribuíram na adoção do plano sagital mediano, da base craniana, neste trabalho.

Como os resultados neste sistema de coordenadas (tabelas 16, 23, 30 e 37 / figura 6.2), no sentido ântero-posterior, foram semelhantes aos do sistema de coordenadas mandibulares, as considerações pertinentes são basicamente as mesmas.

No sentido transversal, a única variável que demonstrou uma diferença estatisticamente significante foi a do ponto condilar médio ao eixo interespinhosos (PCM-EIE, tabela 23). As demais variáveis não apresentaram diferença estatisticamente significante, como demonstrado nas tabelas 23, 30 e 37 . Por esse motivo, considerou-se que o componente esquelético apresentou uma manifestação pouco expressiva, mesmo após o tratamento de casos de Classe II, subdivisão. Aliás, a assimetria dessa variável já havia sido demonstrada no grupo de subdivisão, antes do tratamento (tabela 16). Portanto, pode-se concluir que os tipos de tratamento empregados praticamente não apresentam o potencial de causar alterações esqueléticas na má oclusão original. $\mathrm{Na}$ análise isolada dos casos tratados, nos subgrupos A e B (tabelas 30 e 37), a explicação para a inexistência de diferenças, no sentido transverso deste sistema de coordenadas, baseourse nas médias e nos desvios padrão obtidos. Na tabela 30, não houve diferença estatisticamente significante para a variável PCM-EIE porque, embora a média obtida após o tratamento tenha sido maior do que previamente ao mesmo, o desvio 
padrão também foi maior. Em contrapartida, na tabela 37, não houve diferença significante porque a média obtida após o tratamento foi menor, em relação ao período antes do tratamento, apesar do desvio padrão também ter sido menor.

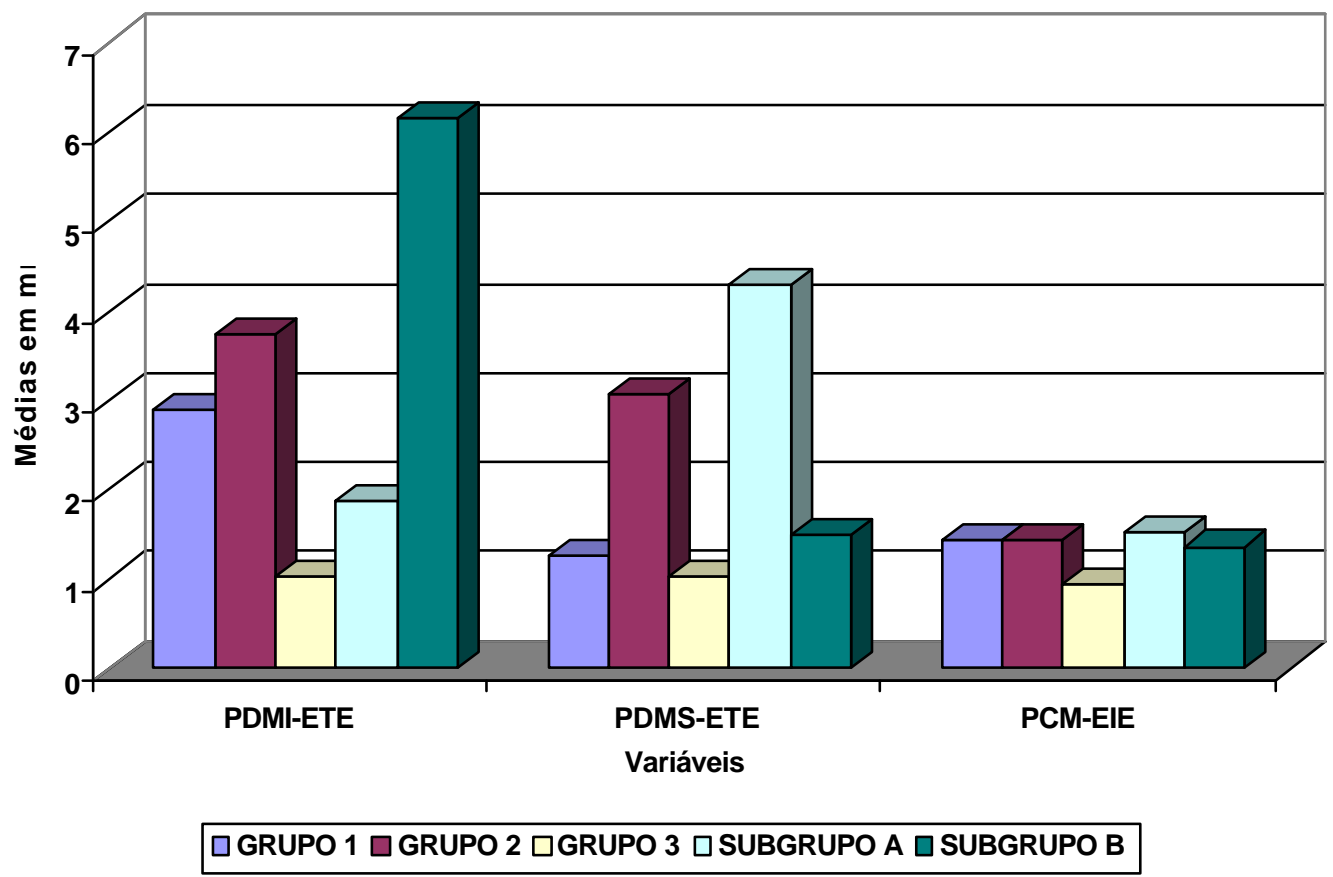

FIGURA 6.2 - Médias das variáveis que apresentaram diferenças estatisticamente significantes no sistema de coordenadas do assoalho craniano, nos sentidos ântero-posterior e transverso

\subsection{3 - Sistema de Coordenadas Zigomaticomaxilares}

De maneira análoga ao sistema de coordenadas do assoalho craniano, como os resultados neste sistema de coordenadas, no sentido ântero-posterior, foram semelhantes, as considerações pertinentes são basicamente as mesmas, com exceção do comportamento da variável PDMS-ETPTM que demonstrou uma diferença estatisticamente significante quando o grupo de oclusão normal foi comparado com o subgrupo B, tratado com três extrações (tabela 38 / figura 6.3). Nos dois sistemas de coordenadas anteriores isso não havia ocorrido. Este resultado demonstra pequena participação da diferença de posição ântero-posterior dos molares superiores na formação da Classe II, subdivisão, mesmo naqueles casos em que o fator preponderante é a diferença de posição ântero-posterior dos 
molares inferiores. Entretanto, como só ocorreu neste sistema de coordenadas, sua contribuição parece ser pequena.

Em relação ao sentido transversal, as variáveis deste sistema de coordenadas não se apresentaram estatisticamente significantes entre os grupos, com exceção da variável do ponto vômer anterior ao eixo interpterigomaxilar (VAEIPTM) para os casos de extração de apenas um pré-molar (tabela 31). Isto confirma a pequena participação dos componentes esqueléticos, uma vez que somente uma variável esquelética denotou significância estatística. Além do mais, como o grupo de Classe II, subdivisão, sem tratamento (tabela 17) não apresentou diferença estatisticamente significante para esta variável em relação ao grupo de oclusão normal e devido à impossibilidade da mecânica ortodôntica afetar esta estrutura, não há motivos para se considerar que haja uma grande participação esquelética na constituição da Classe II, subdivisão, nem antes e nem após o tratamento, com estes protocolos de extrações.

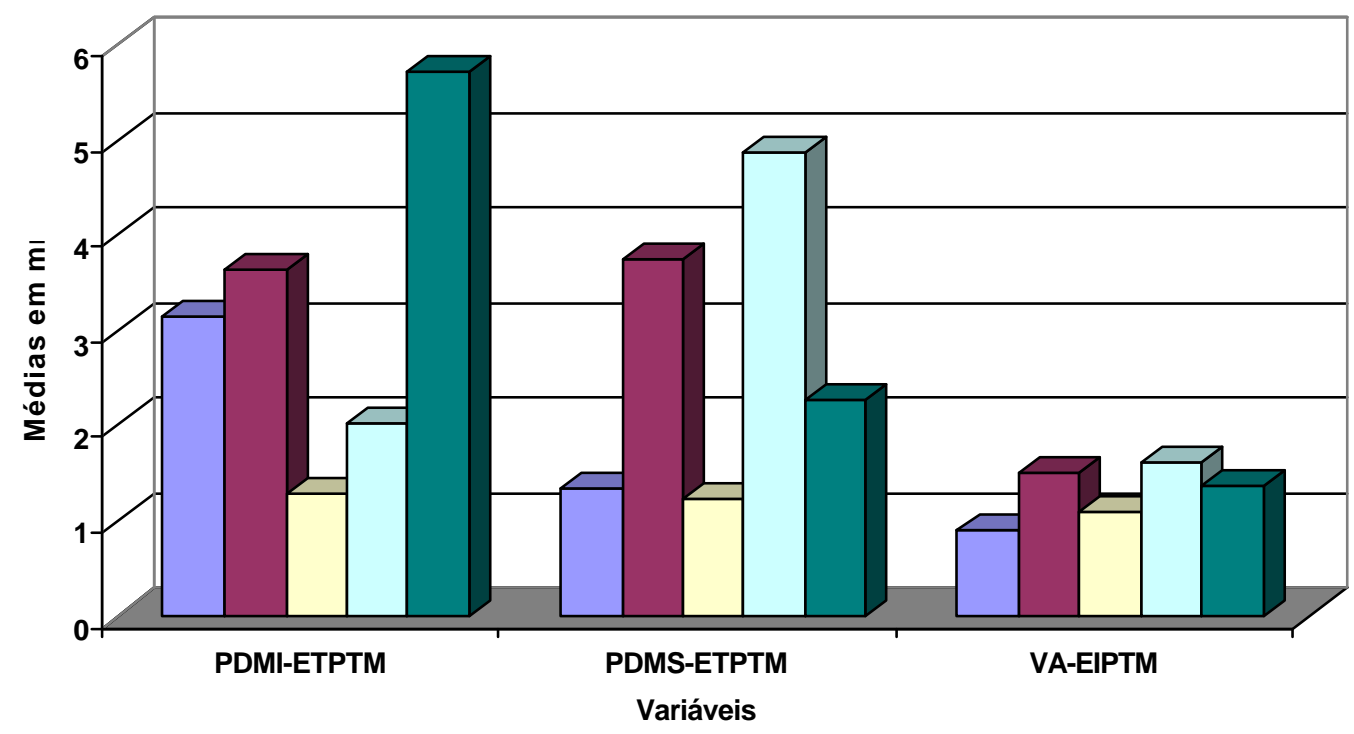

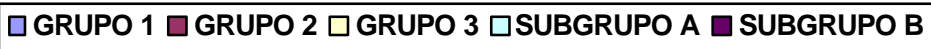

FIGURA 6.3 - Médias das variáveis que apres entaram diferenças estatisticamente significantes no sistema de coordenadas zigomaticomaxilares, nos sentidos ântero-posterior e transverso 


\subsection{4 - Sistema de Coordenadas Dentárias}

Todas as variáveis do grupo tratado (tabela 25) apresentaram diferenças estatisticamente significantes, em relação ao grupo controle de oclusão normal, com aumento das médias ao final do tratamento, quando comparadas com as médias do grupo de Classe II, subdivisão, previamente ao tratamento (tabela 18). Como houve uma combinação de dois diferentes tipos de tratamento (uma extração e três extrações), estas variáveis se comportaram de maneira análoga aos resultados das mesmas, quando comparado o grupo de Classe II, subdivisão, não tratado com o de oclusão normal (tabela 18). Após o tratamento, houve, de uma forma geral, até aumento das médias, porque ocorreu uma movimentação assimétrica dos molares, ocasionando uma rotação do eixo intermolares, e assim, aumentando a distância das estruturas centralizadas até eles.

Após o tratamento, nos casos de extração de um pré-molar superior do lado da Classe II (tabela 32), percebe-se que as medições ao eixo intermolares superiores (EIMS) apresentaram diferenças estatisticamente significantes, enquanto que aquelas ao eixo intermolares inferiores, não. Logicamente que, devido à extração de apenas um pré-molar superior de um dos lados, houve um deslocamento do eixo intermolares superiores, o que provocou uma maior distância das estruturas centrais até os molares. A ausência de diferenças estatisticamente significantes para as variáveis relacionadas ao eixo intermolares inferiores demonstra que quando o grupo de Classe II subdivisão é selecionado de acordo com sua etiologia, no caso, com uma posição mais para mesial dos molares superiores do lado da Classe II, as estruturas centrais apresentam uma maior simetria em relação aos dentes inferiores. Se comparados estes resultados com os obtidos na tabela 18 , nota-se que nesta última, houve diferenças estatisticamente significantes para as variáveis relacionadas ao eixo intermolares inferiores. Novamente, isto reflete a natureza composta dos casos de Classe II, subdivisão previamente ao tratamento. Em outras palavras, o que contribuiu para as diferenças significantes foi a assimetria ântero-posterior dos molares inferiores nos casos de Classe II ocasionados por uma posição mais para distal do molar inferior de um dos lados. 
$\mathrm{Na}$ tabela 39 ocorreu justamente o inverso, ou seja, houve diferenças estatisticamente significantes para as variáveis relacionadas ao eixo intermolares inferiores e não para aquelas relacionadas ao eixo intermolares superiores. A explicação para isso segue um raciocínio análogo ao anteriormente mencionado. Os molares superiores após o tratamento sofreram uma mesialização simultânea com a extração bilateral, permitindo que seus pontos distais ficassem aproximadamente eqüidistantes transversalmente, apresentando médias finais em direção à normalidade. No arco inferior, realizourse a extração assimétrica do lado de Classe I, no sentido de corrigir a linha média dentária inferior desviada para o lado da Classe II e alguma outra discrepância presente no arco. Assim, os molares superiores direito e esquerdo e o molar inferior do lado da Classe I posicionaram-se mais à frente ao final do tratamento, enquanto que o molar inferior do lado da Classe II não se movimentou. Portanto, as maiores diferenças vinculam-se às variáveis relacionadas ao eixo intermolares inferiores, uma vez que um de seus pontos distais localizou-se mais anteriormente, assumindo uma maior diferença sagital, após o tratamento.

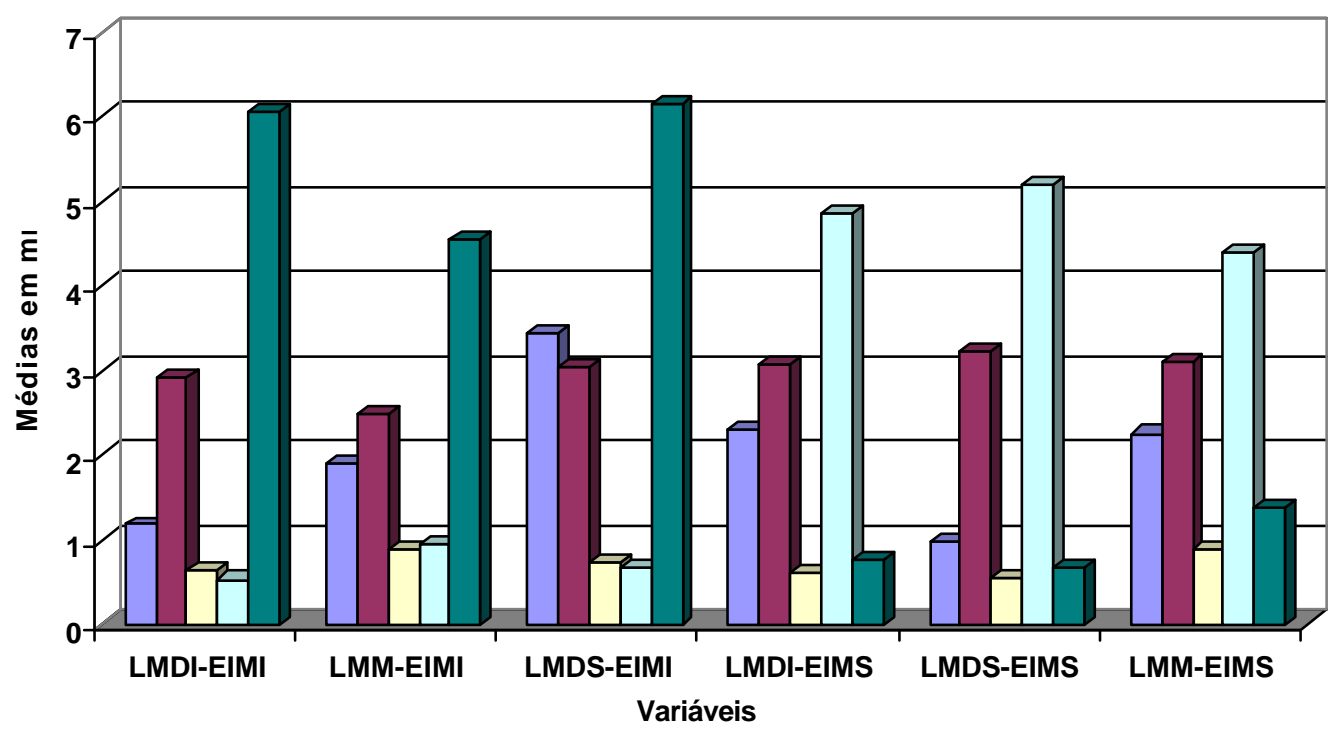

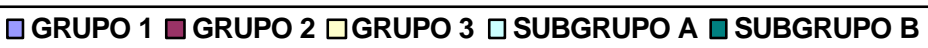

FIGURA 6.4 - Médias das variáveis do sistema de coordenadas dentárias, no sentido transverso 


\subsection{5 - Medidas Angulares}

Os ângulos entre os eixos condilares aos eixos dos forames espinhosos e os ângulos referentes aos eixos transcondilar e transespinhoso ao eixo transpterigomaxilar (EIE.EIC, ETE.ETC, ETPTM.ETC e ETPTM.ETE) não mostraram diferenças estatisticamente significantes entre os grupos, nem antes e nem após o tratamento da Classe II, subdivisão (tabelas 19, 26, 33 e 40). Desta forma, concluiur se que não houve alteração da posição angular esquelética mandibular, na Classe II, subdivisão, em relação à base do crânio ou à maxila, e nem da maxila em relação à base do crânio, com as mecânicas empregadas. Isto demonstra que o uso dos elásticos intermaxilares de Classe II, de Classe III ou diagonais anteriores não tiveram o potencial de causar um desvio funcional mandibular.

Os ângulos entre o eixo transmolar inferior aos eixos transespinhosos, transcondilar e transpterigomaxilar (ETMI.ETE, ETMI.ETC, ETMI.ETPTM) apresentaram diferenças estatisticamente significantes entre o grupo tratado e 0 grupo de oclusão normal (tabelas 26, 33 e 40 / figura 6.5). A explicação para as semelhanças nas tabelas 19 e 26 baseourse no fato de que estes grupos apresentavam más oclusões de Classe II, com diferentes tipos de etiologia, que evidentemente causavam um desvio angular dos eixos intermolares inferiores em relação aos outros eixos. Isto é especialmente válido para a tabela 40 , composta pelos casos de Classe II, subdivisão tratados com extração de três pré-molares, sendo somente um inferior. Por outro lado, na tabela 33, no subgrupo A, que foi tratado somente com a extração de um pré-molar superior devido à sua etiologia ser decorrente da posição do molar superior mais para mesial do lado da Classe II, era de se esperar que os molares inferiores estivessem apresentando uma maior simetria de posição no sentido ântero-posterior. Entretanto, como ainda assim houve essas diferenças, fica demonstrado que mesmo nos casos de Classe II, subdivisão causados principalmente pela posição mais para mesial do molar superior, ainda há uma certa participação da posição assimétrica dos molares inferiores. Já na tabela 40, nos casos de Classe II, subdivisão ocasionados por uma posição mais para distal do molar inferior do lado da Classe II e tratados com 
extrações de três pré-molares, as diferenças estatisticamente significantes para estas variáveis eram previsíveis porque a extração unilateral de um pré-molar inferior causou um desvio do eixo intermolares inferiores em relação aos demais.

Todas as medidas angulares ETMS.ETE, ETMS.ETC e ETMS.ETPTM manifestaram uma diferença significante na análise geral dos casos tratados (tabela 26 / figura 6.5) e, mais especificamente, no subgrupo A (tabela 33). Novamente, na tabela 26, isto se explica pela associação de casos de Classe II, subdivisão, aos diferentes tipos de tratamento neste grupo. O tratamento com extração de somente um pré-molar do lado da Classe II fez com que houvesse um desvio do eixo dos molares superiores em relação aos demais, e assim, houve um aumento deste ângulo, que ao ser comparado com o de oclusão normal apresentou uma diferença estatisticamente significante. Foi isto que ocorreu na tabela 33. Como no grupo total da tabela 26 estes casos também estavam presentes, isto fez com que houvesse uma diferença significante em relação ao grupo de oclusão normal. $\mathrm{Na}$ tabela 40, a única diferença significante foi para a variável ETMS.ETPTM, o que, de certa forma não seria esperado, porque estes casos apresentavam uma Classe II, subdivisão devido principalmente a uma posição mais para distal dos primeiros molares inferiores. Entretanto, isto demonstrou que mesmo nestes casos, pode haver uma pequena participação dos molares superiores, na composição da má oclusão, se bem que em um grau menor do que a dos molares inferiores, nos casos devido principalmente a uma posição mais para mesial dos molares superiores, do lado da Classe II. Esta pequena participação dos molares superiores também pode ser verificada na tabela 19. A única diferença é que a variável diferente estatisticamente é a ETMS.ETC. Esta dessemelhança deste resultado com a tabela 40 pode estar baseada nos diferentes pacientes dos grupos. 


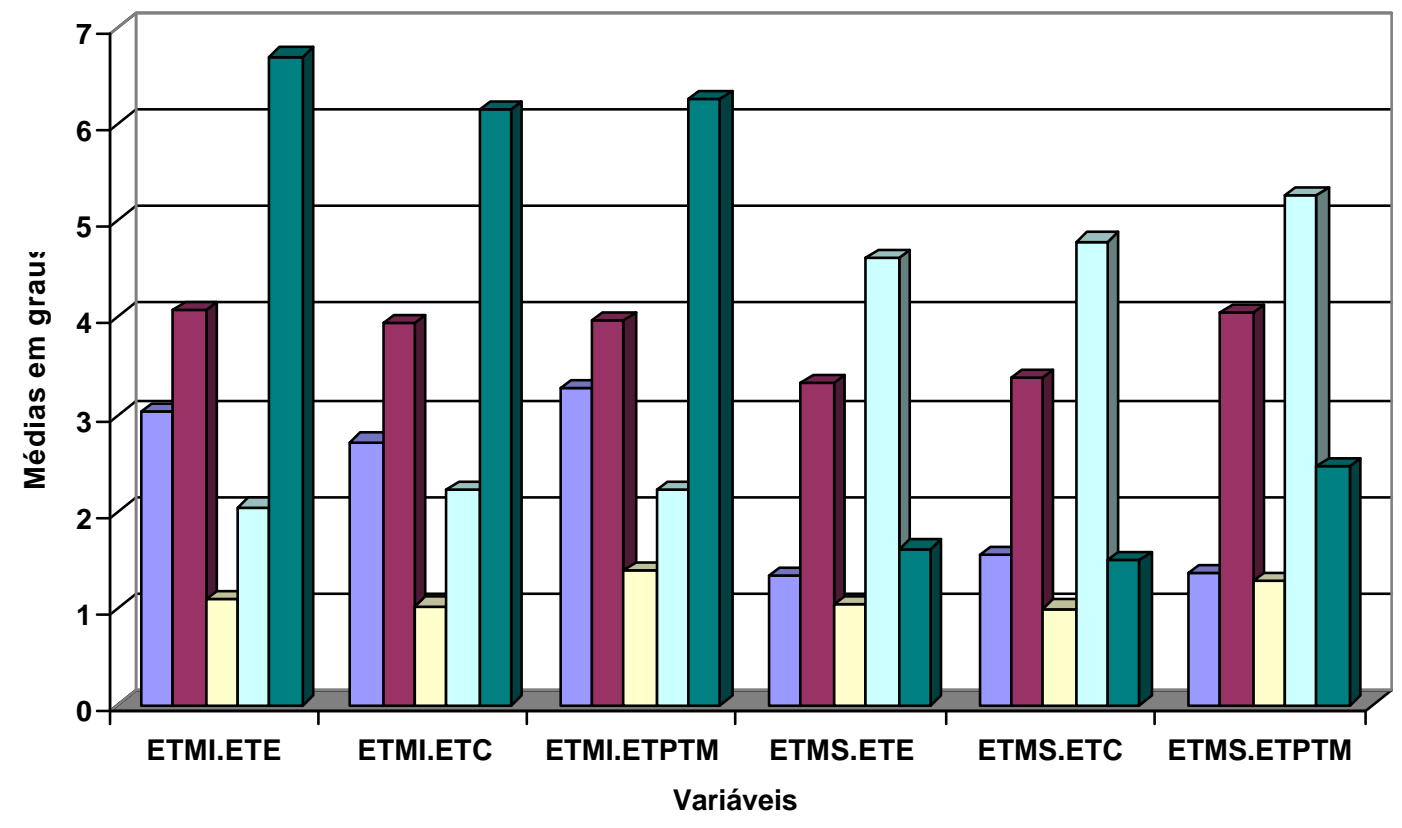

IGRUPO 1 IGRUPO 1 GGRUPO 2 ISUBGRUPO A $\square$ SUBGRUPO B

FIGURA 6.5 - Médias das medidas angulares que apresentaram diferenças estatisticamente significantes

\subsection{6 - Variáveis Adicionais}

As variáveis adicionais esqueléticas que constituem a medição do ponto condilar médio até a linha média mandibular e até o contorno médio da mandíbula (PCM-LMM, PCM-CMM) não se apresentaram significantemente diferentes nem antes e nem após o tratamento (tabelas 20, 27, 34 e 41 / figura 6.6). Desta forma, concluiu-se que não houve alteração esquelética mandibular, na Classe II, subdivisão com as mecânicas empregadas.

As posições laterais dos primeiros molares inferiores e superiores, em relação à borda mandibular (POSM e POSMS), também não apresentaram diferenças estatisticamente significantes entre os grupos tratado e de oclusão normal, 
demonstrando que as mecânicas utilizadas não provocaram efeitos colaterais transversais nestes dentes.

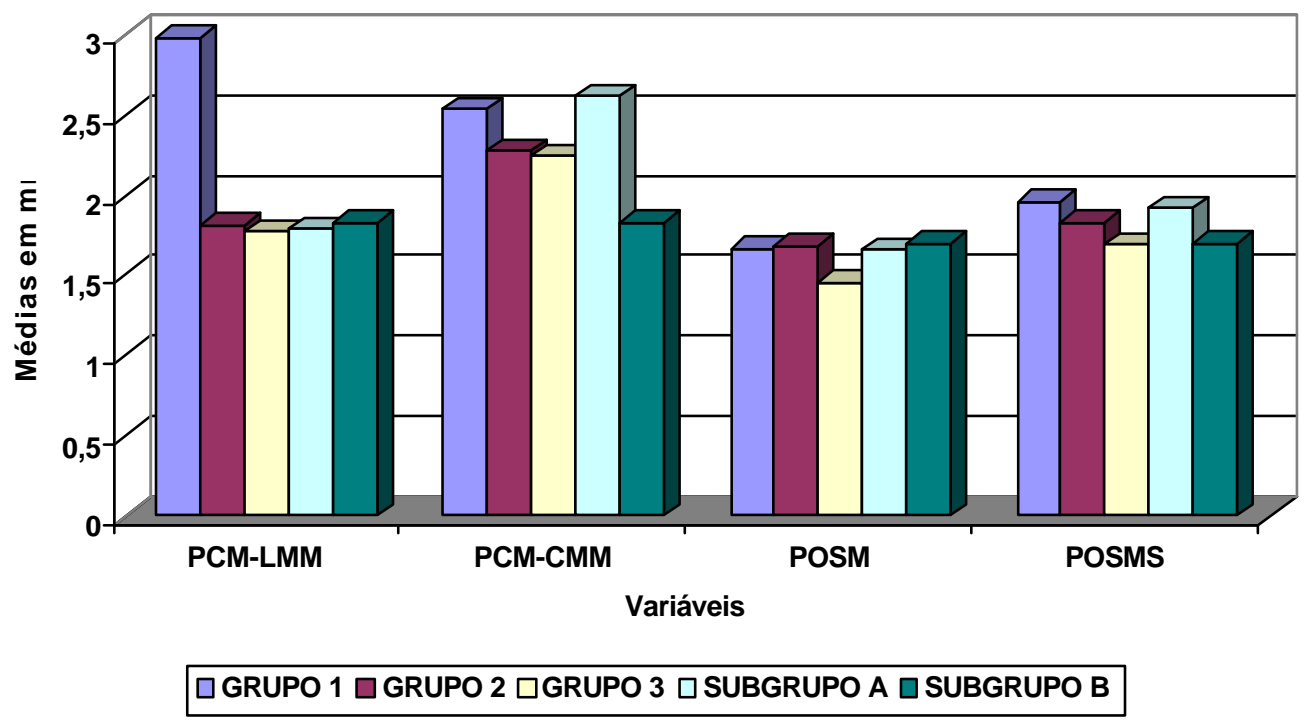

FIGURA 6.6 - Médias dos valores absolutos das variáveis adicionais

\section{6 - Resultados Obtidos nas Radiografias Póstero-Anteriores}

De uma forma geral (tabela 28), o tratamento com extrações assimétricas proporcionou uma melhora dos desvios das linhas médias superior e inferior, em relação ao plano sagital mediano, que os casos de Classe II, subdivisão apresentavam previamente ao tratamento (tabela 21). Entretanto, os casos tratados apenas com extração de um pré-molar superior (tabela 35 / figura 6.7) ainda persistiram apresentando um desvio da linha média superior em relação à linha-X, maior que o normal, na radiografia PA. Provavelmente, isto ocorreu devido ao fato de que mesmo nesses casos em que o fator causal principal da Classe II, subdivisão seja a posição mais para mesial do molar superior do lado da Classe II, ainda há certa participação assimétrica do molar inferior. Estando o molar inferior assimetricamente disposto, isto ocasiona também um certo desvio da linha média inferior. Quando a mecânica estabelece a coincidência das linhas médias dentárias, ao final do tratamento, pode ser que elas não estejam coincidentes exatamente com 
a linha-X. A linha média inferior não apresentou diferença estatisticamente significante em relação ao grupo de oclusão normal, provavelmente porque o valor da média e do desvio padrão, para esta variável, é maior do que o da linha média superior e isto pode ter interferido favoravelmente no cálculo. Por outro lado, os casos de extração de três pré-molares (tabela 42) não demonstraram diferenças estatisticamente significantes para essas variáveis porque nos casos de Classe II subdivisão ocasionados por uma posição mais para distal dos molares inferiores, a participação dos molares superiores é muito pequena e, portanto, não interfere na correção da linha média inferior.

Outro resultado bastante significativo foi que rão houve inclinação do plano oclusal com as mecânicas assimétricas para a correção destes casos, como relatado por muitos autores $21,24,25,41,155,156,157$, e nem alterações esqueléticas desfavoráveis no plano frontal. Entretanto, este resultado deve ser avaliado com cautela, pois reflete a resposta em um grupo, o que não significa que casos individuais não possam apresentar alguma inclinação indesejável.

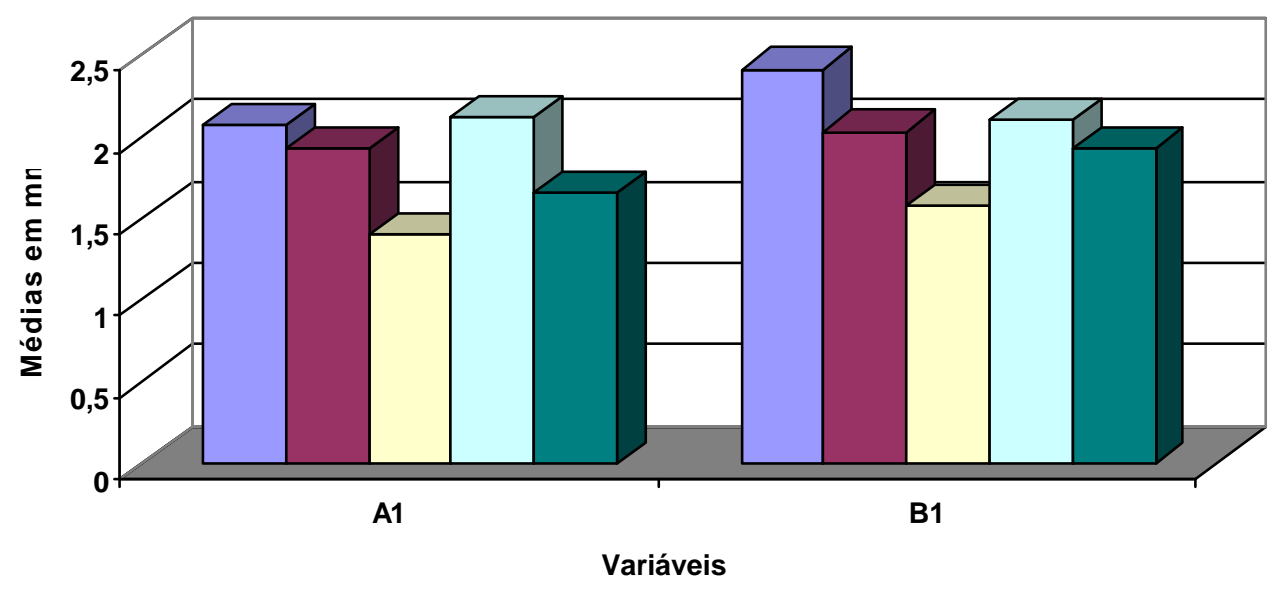

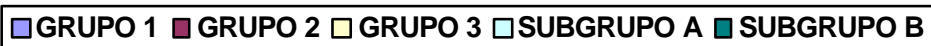

FIGURA 6.7 - Médias dos valores absolutos das variáveis (A1 - Desvio da linha média dentária superior em relação à linha X e B1 - Desvio da linha média dentária inferior em relação à linha $X)$ que apresentaram diferenças estatisticamente significantes, na Radiografia Póstero-Anterior 


\section{7 - Considerações clínicas sobre o tratamento da Classe II, subdivisão}

A má oclusão de Classe II, subdivisão apresenta uma grande variedade de terapêuticas, sendo crucial a determinação dos fatores que causam este problema, ou seja, se decorre de uma assimetria dentária, esquelética ou combinação de ambas estas características ${ }^{73,134}$. Para tanto, o plano de tratamento deve ser voltado para as características e severidade da má oclusão, a idade ${ }^{167}$ e cooperação do paciente $24,25,73,75,104,168,181$. Deste modo, as alterações dentoesqueléticas decorrentes do tratamento das más oclusões de Classe II dependem do tipo de planejamento executado. Quando a terapia é conservadora, recorre-se à ortopedia funcional $^{44,79,102,104,110,132,141,155}$, aos dispositivos intrabucais distalizadores ${ }^{18,35,50,155}$ e aos aparelhos extrabucais assimétricos ${ }^{181}$ que distalizam os molares mesializados, juntamente com a ortodontia fixa, evitando-se as extrações dentárias com uma mecânica assimétrica. Segundo BURSTONE ${ }^{25}$, a terapia com extrações assimétricas deve ser realizada, objetivando uma mecânica simétrica, e nos casos esqueléticos severos, deve-se recorrer à ortodontia em combinação com a cirurgia ortognática, envolvendo ou não extrações. Desta forma, serão comentadas algumas considerações em relação às alterações decorrentes da mecânica empregada na correção dos casos de Classe II, subdivisão, deste trabalho, além de outras formas de tratamento já abordadas na literatura para a solução deste problema.

Pacientes com assimetrias dentoalveolares apresentam algumas das mais desafiadoras mecânicas para o ortodontista. Uma assimetria subclínica ${ }^{34}$ tratada $^{2}$ com extração dentária assimétrica permite a simplificação das mecânicas intra e interarcos, reduzindo também a dependência de colaboração do paciente no uso dos elásticos, encurtando o tempo de tratamento ${ }^{73}$. Além disso, padrões de extrações atípicas podem favorecer o preparo ortodôntico pré-cirúrgico dos casos que envolvem cirurgia ortognática ${ }^{134}$.

Considera-se o posicionamento dentário simétrico um componente importante do sorriso atraente ${ }^{67,77}$, enquanto a assimetria compromete a estética dentária ${ }^{15}$. A coordenação das linhas médias dentárias assume grande importância no plano de tratamento ortodôntico e a complexidade de sua correção aumenta de acordo com a 
duração da terapia ${ }^{89}$. Convém salientar que as três Inhas médias do paciente: a facial, a maxilar e a mandibular devem ser avaliadas durante o diagnóstico para que um plano de tratamento adequado seja implementado ${ }^{77}$. A estética facial, a função, o relacionamento espacial maxilomandibular e a oclusão dentária podem ser influenciados pela angulação ou inclinação do plano oclusal ${ }^{14,21,78,146,152}$.

$\mathrm{Na}$ tentativa de se alcançar a coordenação das linhas médias com a combinação dos elásticos assimétricos de Classe II, de Classe III e diagonal anterior ${ }^{2,4,10,23,49,131}$, podem ocorrer efeitos indesejáveis, uma vez que uma harmonia esquelética já tenha sido obtida. Ainda mais, os vetores de força criados por estes elásticos produzem um momento de força na mandíbula, isto é, uma tendência à rotação que pode estar relacionada a uma alteração transitória na posição mandibular. Ao menos, uma estabilidade do relacionamento esquelético deve ser obtida antes da remoção do aparelho ortodôntico, pois uma recidiva pode ocorrer quando a mandíbula se retroposiciona para uma situação mais fisiológica. Para promover a descontinuidade da assimetria, os elásticos intermaxilares assimétricos de Classe II, Classe III e diagonal anterior devem ser utilizados, até atingir a sobrecorreção, antes da remoção do aparelho, auxiliando na confirmação da estabilidade da posição mandibular ${ }^{134}$.

Resultados do estudo de MILLER; BOODEN; JAMISON ${ }^{107}$, em 1979, indicaram que a linha média maxilar situa-se exatamente na metade do lábio superior, utilizando o filtro como referência, em aproximadamente $70 \%$ dos pacientes. Entretanto, a coincidência das linhas médias maxilar e mandibular ocorre, de um modo geral, em somente $25 \%$ da população.

Os desvios da linha média dentária superior em relação à linha média facial, nos casos de Classe II, subdivisão podem ser causados por múltiplos fatores ${ }^{134}$. Em pacientes em crescimento, muitos recursos podem ser utilizados para se alcançar um relacionamento de molar aceitável nos casos sem extração, incluindo ancoragem extrabucal assimétrica, elásticos de Classe II unilaterais ou um arco transpalatino ativado unilateralmente. Entretanto, nos pacientes adultos, vários fatores são 
desfavoráveis para a correção da Classe II, sem extração. Se um paciente adulto apresenta um arco inferior que não necessita de extrações, a remoção de um prémolar superior do lado da Classe II facilita a correção do canino para uma relação de Classe I, terminando o caso, com uma relação molar de Classe II deste lado, mas com as linhas médias dentárias coincidentes entre si e com o plano sagital mediano ${ }^{73,134}$. Segundo JANSON ${ }^{73}$, esta é uma outra combinação de má oclusão de Classe II, subdivisão, que ocorre menos freqüentemente, apresentando um desvio da linha média dentária superior em relação ao plano sagital mediano, no sentido contrário ao lado da Classe II e coincidência da linha média dentária inferior, em relação a este plano, em casos sem apinhamento superior e inferior. Nos casos de extração no arco superior, pode-se recorrer a um arco transpalatino passivo ou suavemente ativado para controle da ancoragem do molar superior, permitindo que o fechamento do espaço possa ser realizado por meio de uma mecânica de Classe I, com o mínimo de cooperação do paciente ${ }^{134}$.

\subsection{1 - Considerações clínicas quanto às abordagens de tratamento empregadas nos casos de Classe II, subdivisão deste trabalho}

A sistemática de extrações realizadas nos casos de Classe II, subdivisão desta amostra baseourse em premissas ressaltadas na literatura. Treze pacientes apresentavam a linha média dentária superior coincidente ou com um pequeno desvio em relação ao plano sagital mediano, enquanto a linha média dentária inferior apresentava-se desviada para o lado da Classe II, em relação ao plano sagital mediano. Como esta situação ocorre na maioria dos casos de Classe II unilateral, optou-se pela extração de dois pré-molares superiores e um pré-molar inferior do lado da Classe 1,24,32,73,89,134,168,173, já que o perfil dos pacientes permitia certa retração dos incisivos superiores e inferiores ${ }^{73,134}$. A extração de um pré-molar inferior no lado da Classe I, reposiciona o canino numa situação mais distal, relacionando-o corretamente com o seu antagonista, enquanto que a extração de dois pré-molares superiores permite a manutenção da coincidência da linha média dentária superior com a linha média facial. Este planejamento minimiza a utilização de elásticos intermaxilares e reduz o tempo de uso das ancoragens extra e intrabucal, para a finalização do tratamento, simplificando a biomecânica e corrigindo 
as assimetrias dentárias ${ }^{73,134}$. Desta forma, obtém-se uma oclusão final com o lado de Classe I, terminando em Classe I de molar e de canino, enquanto que no lado de Classe II, o molar termina em Classe II e o canino em Classe I, com as linhas médias dentárias superior e inferior coincidentes entre si e com o plano sagital mediano. A correção do desvio de linha média, nesta forma de tratamento, torna-se mais fácil, uma vez que pode ser obtida concomitantemente com o fechamento do espaço da extração do arco inferior ${ }^{73}$. Durante o tratamento, se o molar do lado da Classe II assumir uma relação topo a topo, a mecânica de fechamento de espaço deve ser de Classe I em todos os segmentos do arco, com o mínimo uso de elásticos intermaxilares. Entretanto, se este mesmo molar encontra-se numa relação de Classe II completa, medidas adicionais devem ser necessárias para limitar a perda de ancoragem do molar superior neste lado, por exemplo, colocandose um arco transpalatino para aumentar a ancoragem do molar ${ }^{134}$.

Se o plano de tratamento necessitar da extração de um quarto pré-molar, mais especificamente, um pré-molar inferior do lado da Classe II, todos os espaços da extração no lado da Classe II devem ser fechados pela retração completa dos dentes anteriores superiores e completa mesialização do segmento póstero-inferior para o espaço da extração $32,33,73,134,173$. Desta forma, torna-se preferível a extração de um segundo pré-molar inferior, do lado da Classe II para auxiliar na perda de ancoragem do molar inferior, estabelecendo uma ancoragem diferencial entre os caninos direito e esquerdo e assim, obter uma relação de Classe I destes dentes ${ }^{73}$. Apesar deste segundo esquema de extrações produzir resultados satisfatórios, requer-se uma maior utilização de elásticos intermaxilares para a obtenção da relação de Classe I, de molar deste lado ${ }^{73,134}$. Há uma dificuldade na correção do desvio de linha média, uma vez que para o fechamento do espaço da extração do pré-molar do lado da Classe II, a linha média tende a se deslocar ainda mais para este lado. Nestes casos, pode-se utilizar um arco retangular superior e um arco redondo inferior, com amarrações distais, com dobras de segunda ordem nos caninos inferiores, associados a um elástico de Classe II e um elástico diagonal anterior $^{49,73,89}$, para auxiliar na correção da linha média. Entretanto, esta mecânica 
exige muita colaboração do paciente no uso de aparelhos extrabucais ou elásticos intermaxilares, sendo de prognóstico mais desfavorável ${ }^{73}$.

O tratamento dos outros 17 pacientes analisados baseou-se na presença do desvio da linha média dentária superior em sentido contrário ao lado da Classe II, em relação ao plano sagital mediano e coincidência da linha média dentária inferior, em relação a este plano. Esta combinação de má oclusão de Classe II, subdivisão ocorreu em menor freqüência em estudo realizado anteriormente ${ }^{73}$. Entretanto, nesta amostra houve um maior número de casos com essa característica, provavelmente porque foram os casos que se encontravam melhor terminados na época do início deste estudo. O tratamento destes pacientes baseou-se nos trabalhos de JANSON $^{73}$ e WERTZ ${ }^{173}$ consistindo na extração de apenas um prémolar superior do lado da Classe II, terminando os casos com uma relação molar de Classe II deste lado, mas com as linhas médias dentárias coincidentes entre si e com o plano sagital mediano. Houve necessidade da utilização de ancoragem extrabucal assimétrica, com maior força do lado da Classe II, até a obtenção da relação de Classe I de canino e correção dos ligeiros apinhamentos ânterosuperiores presentes deste lado.

Este trabalho demonstrou que as alterações que ocorrem com estes dois diferentes protocolos de extrações assimétricas são essencialmente dentoalveolares. Essas alterações são preponderantemente favoráveis, sem apresentarem os efeitos colaterais indesejáveis já mencionados na literatura, pelo menos quando analisados no grupo estudado. Entretanto, com a finalidade de se obter resultados semelhantes é necessário que o planejamento seja realizado corretamente, com base nas características iniciais da Classe II, subdivisão apresentada. 


\subsection{2 - Sugestões para Futuras Pesquisas:}

1) Estudo individualizado dos dois diferentes grupos de Classe II, subdivisão quanto às suas características iniciais e após o tratamento ortodôntico, utilizando-se, conseqüentemente, um único protocolo de extração assimétrica.

2) Avaliação dos casos de Classe II, subdivisão pré e pós-tratamento, comparando as inclinações direita e esquerda dos planos oclusais posteriores por meio das radiografias oblíquas corrigidas. 


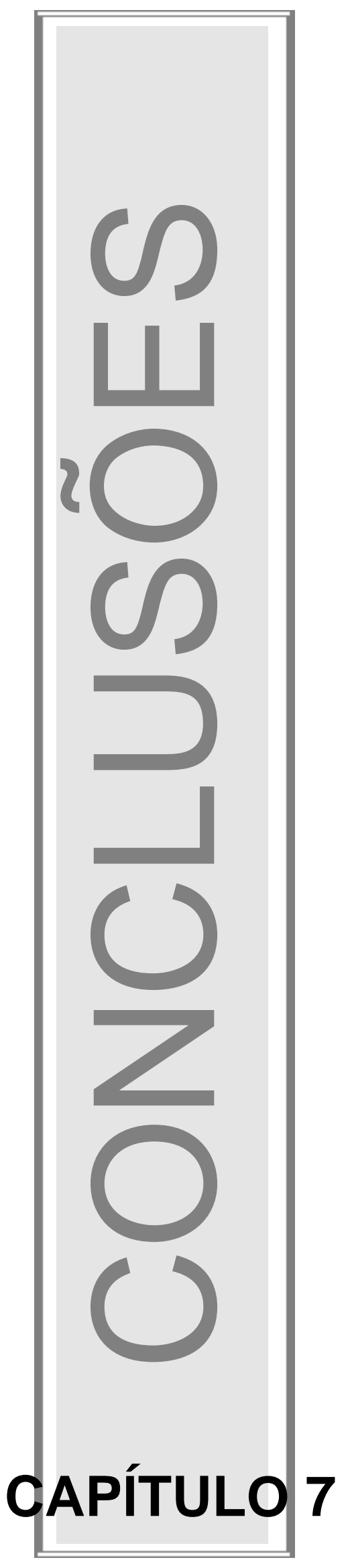




\section{7 - CONCLUSÕES}

om base nos resultados obtidos neste trabalho e de acordo com a
metodologia utilizada para a avaliação das alterações dentoesqueléticas decorrentes do tratamento da Classe II, subdivisão, com extrações assimétricas, em relação a um grupo controle de oclusão normal, julgout se lícito concluir que:

\section{- EM RELAÇÃO ÀS RADIOGRAFIAS SUBMENTONIANAS:}

1. As extrações assimétricas nas más oclusões de Classe II, subdivisão acentuaram as assimetrias ântero-posteriores entre os lados direito e esquerdo, dos primeiros molares superiores e inferiores.

2. Não houve alterações esqueléticas significantes que pudessem ser atribuídas às formas de tratamento investigadas.

3. Não houve efeitos colaterais transversais nas posições laterais dos primeiros molares inferiores e superiores, após o tratamento, com as mecânicas assimétricas empregadas.

\section{- EM RELAÇÃO ÀS RADIOGRAFIAS PÓSTERO-ANTERIORES:}

1. Obtém-se uma posição normal das linhas médias dentárias superior e inferior com o plano sagital mediano, quando a Classe II, subdivisão é tratada com extrações assimétricas.

2. Os protocolos de extrações assimétricas da Classe II, subdivisão não promovem alterações dentoesqueléticas desfavoráveis no plano frontal. 


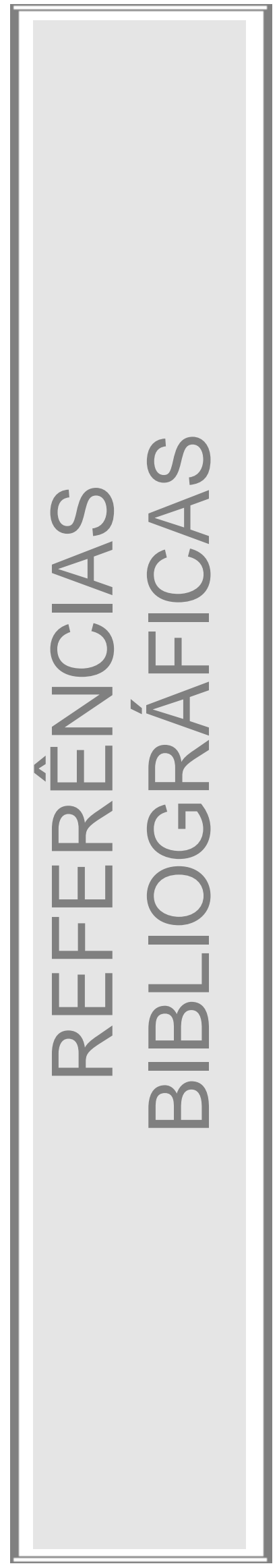




\section{REFERÊNCIAS BIBLIOGRÁFICAS*}

1 ALAVI, D. G.; BEGOLE, E. A.; SCHNEIDER, B. J. Facial and dental arch asymmetries in Class II subdivision malocclusion. Amer. J. Orthodont. Dentofac. Orthop., v.93, n.1, p.38-46, Jan. 1988.

2 ALEXANDER, R. G. The Alexander discipline. Glendora, CA, ORMCO, 1987.

3 ANGLE, E. H. Classification of malocclusion. Dental Cosmos, v.41, n.3, p.248-64, Mar. 1899.

4 ANGLE, E. H. Malocclusion of the teeth. 7.ed. Philadelphia, S. S. White, 1907apud JERROLD, L.; LOWENSTEIN, L. J. ${ }^{77}$ p.457.

5 ARNOLD, T. G.; ANDERSON, G. C.; LILYEMARK, W. F. Assessment of craniofacial asymmetry with S-V radiographs. Amer. J. Orthodont. Dentofac. Orthop., v.106, n.3, p.250-6, Sept. 1994.

6 AZAZ, B.; NITZAN, D. W.; BRIN, L. Condylar hyperplasia: remodeling of facial structures following condylectomia: report of two cases. Int. J. Orthodont. Orthog. Surg., v.6, n.1, p.47-55, Mar. 1991.

7 BAKER, W. L. The influence of the forces of occlusion on the development of the bones of the skull. Int. J. Orthodont. Oral Surg. Radiol., v.8, p.259, 1922.

8 BARBER, T. K.; PRUZANSKY, S.; KINDELSPERGER, R. An evaluation of the oblique cephalometric film. J. Dent. Child., v. 28, n.2, p.94-105, 1961.

9 BAUMRIND, S.; FRANTZ, R. The reliability of head film measurements. Amer. J. Orthodont., v.60, n.2, p.111-27, Aug. 1971.

\footnotetext{
* Normas recomendadas para uso no âmbito da Universidade de São Paulo, com base no documento "Referências Bibliográficas: exemplos", emanado do Conselho Supervisor do Sistema Integrado de Bibliotecas da USP, em reunião de 20 de setembro de 1990.
} 
10 BEGG, P. R.; KESLING, P. Begg orthodontic theory and technique. 3. ed. Philadelphia, W. B. Saunders, 1977.

11 BERGAMINI, A.; MELSEN, B. Case report: treatment of dental asymmetry. Angle Orthodont., v.65, n.4, p.247-52, July 1995.

12 BERGER, H. Problems and promises of basilar view cephalograms. Angle Orthodont., v.31, n.4, p.237-45, Oct. 1961.

13 BERGER, H. Progress with basilar view cephalograms. Trans. Europ. Orthodont. Soc., v.40, p.159-64, 1964.

14 BEYER, J. W.; LINDAUER, S. Evaluation of dental midline position. Seminars in Orthodontics, v.4, n.3, p.146-52, Sept. 1998.

15 BISHARA, S. E.; BURKEY, P. S.; KHAROUF, J. G. Dental and facial asymmetries: a review. Angle Orthodont., v.64, n.2, p.89-98, Mar. 1994.

16 BISHARA, S. E.; TREDER, J. E.; JAKOBSEN, J. R. Facial and dental changes in adulthood. Amer. J. Orthodont. Dentofac. Orthop., v.106, n.2, p.17586, Aug. 1994.

17 BJÖRK, A.; BJÖRK, L. Artificial deformation and craniofacial asymmetry in ancient peruvians. J. dent. Res., v.43, n.3, p.353-63, May/June 1964.

18 BLACKWOOD, H. O. Clinical management of the jasper jumper. J. clin. Orthodont., v.25, n.12, p.755-60, Dec.1991.

19 BRASH, J. C.; MCKEAG, H. T. A. The aetiology of irregularity and malocclusion of the teeth. Dental Board of U.K. London, 1956 apud SHAH, S. M.; JOSHI, M. R. ${ }^{151}$ p.142.

20 BRAUN, S. Achieving improved visualizations of the temporomandibular joint condyle and fossa in the sagittal cephalogram and a pilot study of their relationships in habitual occlusion. Amer. J. Orthodont. Dentofac. Orthop., v.109, n.6, p.635-8, June 1996. 
21 BRAUN, S.; LEGAN, H. Changes in the occlusion related to the cant of the occlusal plane. Amer. J. Orthodont. Dentofac. Orthop., v.111, n.2, p.1848, Feb. 1997.

22 BREAKSPEAR, E. K. Some aspects of the retraction of upper incisors by appliances. $38^{\text {th }}$ Congress, European Orthodontic Society. J. Europ. Orthodont. Soc., v.342, 1963 apud JERROLD, L.; LOWENSTEIN, L. J. ${ }^{77}$ p.453.

23 BUCHIN, I. D. JCO Interviews. J. clin. Orthodont., v.1, n.11, p.103-10, Nov. 1967.

24 BURSTONE, C. J. JCO Interviews: on the uses of the computer in orthodontic practice (Part 1). J. clin. Orthodont., v.13, n.7, p.442-53, July 1979.

25 BURSTONE, C. J. Diagnosis and treatment planning of patients with asymmetries. Seminars in Orthodontics, v.4, n.3, p.153-64, Sept. 1998.

26 CAMPBELL, J. The mylohyoid line in the assessment of facial asymmetry. Dent. Rec., v.52, n.9-10, p.204-8, Sept./Oct. 1950.

27 CARTWRIGHT, L. J.; HARVOLD, E. P. Improved radiographic results in cephalometry through the use of high kilovoltage. J. Canad. dent. Ass., v.20, n.5, p.261-3, May 1954.

28 CASSIDY, D. W. et al. A comparision of surgery and orthodontics in "borderline" adults with Class II, division 1 malocclusions. Amer. J. Orthodont. Dentofac. Orthop., v.104, n.5, p.455-70, Nov. 1993.

29 CETLIN, N. M.; TEN HOEVE, A. T. Non extraction treatment. J. clin. Orthodont., v.17, n.6, p.396-404, June 1983.

30 CHATE, R. A. C. The propellant unilateral magnetic appliance (PUMA): a new technique for hemifacial microssomia. Europ. J. Orthodont., v.17, p.263$71,1995$. 
31 CHEBIB, F. S.; CHAMMA, A. M. Indices of craniofacial asymmetry. Angle Orthodont., v.51, n.3, p.214-25, July 1981.

32 CHENEY, E. A. The influence of dentofacial asymmetries upon treatment procedures. Amer. J. Orthodont., v.38, n.2, p.934-45, July 1952.

33 CHENEY, E. A. Dentofacial asymmetries and their clinical significance. Amer. J. Orthodont., v.47, n.2, p.814-29, Feb. 1961.

34 COOK, J. T. Asymmetry of the craniofacial skeleton. Brit. J. Orthodont., v.7, n.1, p.33-8, Jan. 1980.

35 COPE, J. B. et al. Quantitative evaluation of craniofacial changes with jasper jumper therapy. Angle Orthodont., v.64, n.2, p.113-22, Mar. 1994.

36 CRUZ, K. S. et al. Efeitos dos aparelhos funcionais na correção da má oclusão de Classe II. Rev. Dental Press Ortodon. Ortop. Facial, v.5, n.2, p.1-10, jul./ago. 2000. /no prelo/

37 DAHLBERG, G. Statistical methods for medical and biological students. New York, Interscience, 1940.

38 DAWSON, P. E. Evaluation, diagnosis and treatment of occlusal problems. St. Louis, C. V. Mosby, 1974.

39 ENLOW, D. H. Facial growth. 3. ed. Philadelphia, W. B. Saunders, 1990.

40 ENLOW, D. H.; KURODA, T.; LEWIS, A. B. The morphological and morphogenetic basis for craniofacial form and pattern. Angle Orthodont., v.41, n.3, p.161-88, July 1971.

41 ERDOGAN, E.; ERDOGAN, E. Asymmetric application of the jasper jumper in the correction of midline discrepancies. J. clin. Orthodont., v.32, n.3, p.170-80, Mar. 1998. 
42 FERGUSON, J. W. Cephalometric interpretation and assessment of facial asymmetry secondary to congenital torticolis. Int. J. oral Maxillofac. Surg., v.22, p.7-10, 1993.

43 FERRARIO, V. F. et al. Craniofacial morphometry by photographic evaluations. Amer. J. Orthodont. Dentofac. Orthop., v.103, n.4, p.327-37, Apr. 1993.

44 FIORENTINO, G.; MELSEN, B. Asymmetric mandibular space closure. J. clin. Orthodont., v.30, n.9, p.519-23, Sept. 1996.

45 FISCHER, B. Asymmetries of the dentofacial complex. Angle Orthodont., v.24, n.4, p.179-97, Oct. 1954.

46 FORSBERG, C. T.; BURSTONE, C. J.; HANLEY, K. J. Diagnosis and treatment planning of skeletal asymmetry with the submentak-vertical radiograph. Amer. J. Orthodont., v.85, n.3, p.224-37, Mar. 1984.

47 GAVAN, J. A.; WASHBURN, S. L.; LEWIS, P. H. Photography: an anhropometric tool. Amer. J. phys. Anthrop., v.10, p.331-53, 1952.

48 GIAMBATTISTINI, C. Evaluation of accuracy of the $45^{\circ}$ oblique and corrected oblique in assessing mandibular asymmetry. Toronto, 1997.130p. Master's Thesis - Faculty of Dentistry, Univertsity of Toronto.

49 GiANELLY, A. A.; PAUL, I. A. A procedure for midline correction. Amer. J. Orthodont., v.58, n.3, p.264-7, Sept. 1970.

50 GIANELLY, A. A.; BEDNAR, J.; DIETZ, V. S. Japonese niti coils used to move molars distally. Amer. J. Orthodont. Dentofac. Orthop., v.99, n.6, p.54666, June 1991.

51 GILBERT, D. H. Radiograph method of basilar cephalometrics. (Abstr.) Amer. J. Orthodont., v.46, p.384-5, May 1960. /Abstract/ 
52 GRAVELY, J. F.; BENZIES, P. M. The clinical significance of tracing error in cephalometry. Brit. J. Orthodont., v.1, p.95-101, 1974.

53 GRAYSON, B. H.; MCCARTHY, J. G.; BOOKSTEIN, F. An analysis of craniofacial asymmetry cephalometric analysis. Amer. J. Orthodont. Dentofac. Orthop., v.84, n.3, p.217-24, Sept. 1983.

54 GRAYSON, B. H. et al. Basilar multiplane cephalometric analysis. Amer. J. Orthodont. Dentofac. Orthop., v.88, n.6, p.503-16, Dec. 1985.

55 GRUMMONS, D. C.; VAN DE COPPELLO, M. A. K. A Frontal asymmetry analysis. J. clin. Orthodont., v.21, n.7, p.448-65, July 1987.

56 HABERLE, F. E. A quantitative study of the malocclusion and correction in the posterior segment of the arches of 16 patients. Chicago, 1937. Master's Thesis - Northwestern University.

57 HARVOLD, E. P. The asymmetries of the upper facial skeleton and their morphological significance. Trans. Europ. Orthodont. Soc., p.63-9, 1951.

58

A roentgen study of the postnatal morphogenesis of the facial skeleton in cleft palate. Oslo, Department of Anthropology and Norwegian Dental School, Anatomical Institute, University of Oslo, 1954.

59 HATALA, M. P. et al. Effect of a surgically crested disk displacement on the mandibular symmetry in the growing rabbit. Oral Surg., v.82, n.6, p.625-33, Dec. 1996.

60 HATTON, M. E.; GRAINGER, R. M. Reliability of measurements from cephalograms at the Burlington Orthodontic Research Centre. J. dent. Res., v.37, n.5, p.853-9, Sept./Oct. 1958.

61 HECHTER, F. J. Symmetry of the form and dimension of the dental arches of orthodontically treated patients. Winnipeg, 1975. Master's Thesis - University of Manitoba. 
62 HENRIQUES, J. F. C. Estudo cefalométrico comparativo, de três tipos de ancoragem extrabucal, sobre as estruturas dentoesqueléticas em pacientes com Classe II, 1a divisão. Bauru, 1993. 181p. Tese (Livre Docência) - Faculdade de Odontologia de Bauru, Universidade de São Paulo.

63 HENRIQUES, J. F. C. et al. Tratamento da Classe II, $1^{\text {a }}$ divisão com o aparelho regulador funcional de Fränkel (FR). Apresentação de um caso clínico. Rev. Dental Press Ortodon. Ortop. Facial, v.3, n.1, p.23-31, jan./fev. 1998.

64 HERSHEY, H.; HOUGHTON, C. W.; BURSTONE, C. J. Unilateral face bows: a theoretical and laboratory analysis. Amer. J. Orthodont., v.79, n.3, p.229-49, Mar. 1981.

65 HERZBERG, B. L. Facial esthetics in relation to orthodontic treatment. Angle Orthodont., v.22, n.1, p.3-22, Jan. 1952.

66 HOUSTON, W. J. B. The analysis of errors in orthodontic measurements. Amer. J. Orthodont., v.83, n.5, p.382-90, May 1983.

67 HULSEY, C. M. An esthetic evaluation of lip-teeth relationships present in the smile. Amer. J. Orthodont. Dentofac. Orthop., v.57, n.2, p.132-43, Feb. 1970.

68 HUNTER, W. S. Lateral asymmetries of 93 maxillary arches. Acta odont. scand., v.11, p.95-9, 1953.

69 ISBERG, A. M.; ELIASSON, S. A cephalometric analysis of patients with coronoid process enlargement and locking. Amer. J. Orthodont. Dentofac. Orthop., v.97, n.1, p.35-40, Jan. 1990.

70 ISBERG, A. M. et al. Coronoid process elongation in rhesus monkeys (Macaca mulatta) after experimentally induced mandibular hypomobility: a cephalometric and histologic study. Oral Surg., v.70, p.704-10, 1990. 
71 JACKSON, A. F. Facts, fictions and fallacies in orthodontia. Amer. J. Orthodont., v.23, p.1073-95, 1937.

72 JACOBSON, A. et al. Mandibular prognatism. Amer. J. Orthodont., v.66, n.2, p.140-71, Aug. 1974.

73 JANSON, G. R. P. Estudo tridimensional das assimetrias dentárias e esqueléticas na má oclusão de Classe II, subdivisão. Bauru, 1998. 271p. Tese (Livre-Docência) - Faculdade de Odontologia de Bauru, Universidade de São Paulo.

74 JANSON, G. R. P.; METAXAS, A.; WOODSIDE, D. G. Variation in maxillary and mandibular molar and incisor vertical dimension in 12-year-old subjects with excess, normal and short lower anterior face height. Amer. J. Orthodont. Dentofac. Orthop., v.106, n.4, p.409-18, Oct. 1994.

75 JANSON, G. R. P. et al. A assimetria dentária e suas implicações no tratamento ortodôntico: apresentação de um caso clínico. Ortodontia, v.26, n.3, p.68-73, set./dez. 1995.

76 JANSON, G. R. P. et al. Cephalometric evaluation of the eruption guidance appliance in Class II, division 1 treatment. J. clin. Orthodont., v.31, n.5, p.299-306, May 1997.

77 JERROLD, L.; LOWENSTEIN, L. J. The midline: diagnosis and treatment. Amer. J. Orthodont. Dentofac. Orthop., v.97, n.6, p. 453-62, June 1990.

78 JOHNSTON, C. D.; BURDEN, D. J.; STEVENSON, M. R. The influence of dental to facial midline discrepancies on dental attractiveness ratings. Europ. J. Orthodont., v.21, n.5, p.517-22, Oct. 1999.

79 KAHL-NIEKE, B.; FISCHBACH, R. Effect of early orthopedic intervention on hemifacial microssomia patients: an approach to a cooperative evaluation of treatment results. Amer. J. Orthodont. Dentofac. Orthop., v.114, n.5, p.538-57, Nov. 1998. 
80 KANTOMAA, T. The relation between mandibular configuration and the shape of the glenoid fossa in the human. Europ. J. Orthodont., v.11, p.77-81, 1989.

81 KROGMAN, W. M.; SASSOUNI, V. Syllabus in roentgenographic cephalometry. Philadelphia Center for Research in Child Growth. Philadelphia, 1957 apud LETZER, G. M.; KRONMAN, J. H. ${ }^{87}$ p.205.

82 KRONMILLER, J. E. Development of asymmetries. Seminars in Orthodontics, v.4, n.3, p.134-7, Sept. 1998.

83 KULA, K.; ESMAILNEJAD, A.; HASS, A. Dental arch asymmetry in children with large overjets. Angle orthodont., v.68, n.1, p.45-62, Feb. 1998.

84 LAM, P. H.; SADOWSKY, C.; OMERZA, F. Mandibular asymmetry and condilar position in children with unilateral posterior crossbites. Amer. J. Orthodont. Dentofac. Orthop., v.115, n.5, p.569-76, May 1999.

85 LEGAN, H. L. Surgical correction of patients with asymmetries. Seminars in Orthodontics, v.4, n.3, p.189-98, Sept. 1998.

86 LEGRELL, P. E.; ISBERG, A. Mandibular length and midline asymmetry after experimentally induced temporomandibular joint disk displacement in rabbits. Amer. J. Orthodont. Dentofac. Orthop., v.115, n.3, p.247-53, Mar. 1999.

87 LETZER, G. M.; KRONMAN, J. H. A posterior cephalometric evaluation of craniofacial asymmetry. Angle Orthodont., v.37, n.3, p.205-11, July 1967.

88 LEW, K. K. K.; TAY, D. K. L. Submentovertex cephalometric norms in male Chinese subjects. Amer. J. Orthodont. Dentofac. Orthop., v.103, n.3, p.247-52, Mar. 1993.

89 LEWIS, D. The deviated midline. Amer. J. Orthodont., v.70, n.6, p.601-16, Dec. 1976. 
90 LIN, T. et al. Posteroanterior cephalometric assessment of different malocclusions in adults. Int. J. Adult. Orthodont. Orthognat. Surg., v.12, n.4, p.308-17, Dec. 1997.

91 LINDAUER, S. J. Introduction. Seminars in Orthodontics. v.4, n.3, p.133, Sept. 1998.

92 LINDER-ARONSON, S. Early interceptive treatment of asymmetry. Proc. Fin. dent. Soc., v.87, n.1, p.159-66, Jan. 1991.

93 LIVIERATOS, F. A.; JOHNSTON, L. E. A comparision of one-stage and twostage nonextraction alternatives in matched Class II samples. Amer. J. Orthodont. Dentofac. Orthop., v.108, n.2, p.118-31, Aug. 1995.

94 LUDWIG, W. Rechts-links-problem im Tierreich und beim menschen. Monograph. Physiol. Pfl. Tiere, v.27, 1932 apud LUNDSTRÖM, A. ${ }^{95}$ p. 84.

95 LUNDSTRÖM, A. Some asymmetries of the dental arches, jaws, and skull, and their etiological significance. Amer. J. Orthodont., v.47, n.2, p.81-106, Feb. 1961.

96 MARMARY, Y.; SILBERMAN, Y.; MIRSKY, Y. Use of foramina spinosa to determine skull midlines. Angle Orthodont., v.49, n.4, p.263-8, Apr. 1979.

97 MARTINS de ARAÚJO, T.; SCHIRMER, R. W.; ALMEIDA, M. A. Skeletal and dental arch asymmetries in individuals with normal dental occlusions. Int. J. Adult Orthodont. Orthognat. Surg., v.9, n.2, p.111-8, June 1994.

98 MARTINS de ARAÚJO, T.; SCHIRMER, R. W.; ALMEIDA, M. A. Skeletal and dental arch asymmetries in Class II, division 1, subdivision malocclusions. J. clin. pediat. Dent., v.18, n.3, p.181-5, June 1994.

99 MAURICE, T. J.; KULA, K. Dental arch asymmetry in the mixed dentition. Angle Orthodont., v.68, n.1, p.37-44, Feb. 1998. 
100 MCNAMARA JUNIOR, J. A. Components of Class II malocclusion in children 8-10 years of age. Angle Orthodont., v.51, n.3, p.177-202, July 1981.

101 MELNIK, A. K. A cephalometric study of mandibular asymmetry in a longitudinally followed sample of growing children. Amer. J. Orthodont. Dentofac. Orthop., v.101, n.4, p.355-66, Apr. 1992.

102 MELSEN, B. Asymmetric development of the cranio-facial skeleton: etiology, pathogenesis and treatment. In: INTERNATIONAL SYMPOSIUM ON FEEDING AND DENTOFACIAL DEVELOPMENT 2., Chicago, 1988. Proceedings. Chicago, 1988. p.37.

103 MELSEN, B.; FIORELLI, G. Biomechanics: computer-based mechanoteraphy. J. clin. Orthodont., v.28, n.3, p.136-41, Mar. 1994.

104 MELSEN, B.; BJERREGAARD, J.; BUNDGAARD, M. The effect of treatment with functional appliances on a pathologic growth pattern of the condyle. Amer. J. Orthodont. Dentofac. Orthop., v.90, n.6, p.503-12, Dec. 1986.

105 MERRILL, V. Atlas of roentgenographic positions. Saint Louis, C.V. Mosby, 1949.

106 METAXAS, A. A radiographic study for the assessment of mandibular asymmetry. Athens, 1993. PhD Thesis - University of Athens.

107 MILLER, E. L.; BOODEN, W. R.; JAMISON, H. C. A study of the relationship of the dental midline to the facial median line. J. prosth. Dent., v.41, p.65760, 1979.

108 MIZUNO, A. et al. Treatment of an asymmetric mandibular prognathism in an acromegalic patient. J. oral Maxillofac. Surg., v.46, n.4, p.314-20, Apr. 1988.

109 MONGINI, F. Remodelling of the temporomandibular condyle in the adult and its relationship to the conditions of the dental arches. Acta anat, v.82, p.292-300, 1972. 
110 MONGINI, F.; SCHMID, W. Treatment of mandibular asymmetries during growth: a longitudinal study. Europ. J. Orthodont., v.9, n.1, p.51-67, Feb. 1987.

111 MOORE, G. R.; HUGHES, B. O. Familial factors in diagnosis, treatment, and prognosis of dentofacial disturbancies. Amer. J. Orthodont., v.28, n.10, p.603-39, Oct. 1942.

112 MOSS, M. I.; SALENTIJN, I. Differences between the functional matrices in the anterior open bite and in deep overbite. Amer. J. Orthodont. Dentofac. Orthop., v.60, n.6, p.264-80, Sept. 1971.

113 MOYERS, R. E. et al. Differential diagnosis of Class II malocclusions (Part 1). Facial types associated with Class II malocclusions. Amer. J. Orthodont., v.78, n.5, p.477-94, Nov. 1980.

114 MULICK, J. F. An investigation of craniofacial asymmetry using the serial twin study method. Amer. J. Orthodont. Dentofac. Orthop., v.51, n.2, p.11229, Feb. 1965.

115 NAHOUM, H. I.; FIASCONARO, J.; DI SALVO, N. A. The verticosubmental roentgenogram in cephalometrics. J. Amer. dent. Ass., v.69, p.133-50, Aug. 1964.

116 O'BYRN, B. L. et al. An evaluation of mandibular asymmetry in adults with unilateral posterior crossbite. Amer. J. Orthodont. Dentofac. Orthop., v.107, n.4, p.394-400, Apr. 1995.

117 O'REILLY, B. L.; NANDA, S. K.; CLOSE, J. An evaluation of mandibular asymmetry in adults with unilateral posterior crossbite. Amer. J. Orthodont. Dentofac. Orthop., v.103, n.6, p.504-9, June 1993.

118 OGAARD, B.; KROGSTAD, O. Craniofacial structure and soft tissue profile in patients with severe hypodontia. Amer. J. Orthodont. Dentofac. Orthop., v.108, n.5, p.472-7, Nov. 1995. 
119 OKESON, J. P. Management of temporomandibular disorders and occlusion. 2.ed. Saint Louis, C. V. Mosby, 1989.

120 PANCHERZ, $\mathrm{H}$. The nature of Class II relapse after Herbst appliance treatment: a cephalometric long-term investigation. Amer. J. Orthodont., v.100, n.3, p.220-33, Sept. 1991.

121 PEARSON, K.; WOO, T. L. Further investigation of the morphometric characters of individual bones of the human skull. Biometrika, v.2, p.24265, 1935.

122 PECK, S.; PECK, L.; KATAJA, M. Skeletal asymmetry in esthetically pleasing faces. Angle Orthodont., v.61, n.1, p.43-8, Spring 1991.

123 PELTOLA, J. L.; KONUNEM, M.; NYSTROM, M. Radiographic characteristics in mandibular condyles of orthodontic patients before treatment. Europ. J. Orthodont., v.17, n.1, p.69-77, Feb. 1995.

124 PIRTTINIEMI, P. Normal and increased functional asymmetries in the craniofacial area. Acta odont. scand., v.56, n.6, p.342-5, Dec. 1998.

125 PIRTTINIEMI, P.; KANTOMAA, T. Relation of glenoid fossa morphology to mandibulofacial asymmetry, studied in dry human Lapp skulls. Acta odont. scand., v.50, n.4, p.235-43, Aug. 1992.

126 PIRTTINIEMI, P.; KANTOMAA, T.; RONNING, O. Relation of glenoid fossa to craniofacial morphology, studied on dry human skulls. Acta odont. scand., v.48, n.6, p.359-64, Nov. 1990.

127 PIRTTINIEMI, P. et al. Relationships of bicondylar position to oclusal asymmetry. Europ. J. Orthodont., v.13, n.6, p.441-5, Dec. 1991.

128 POLLARD, L. E.; MAMANDRAS, A. H. Male postpubertal facial growth in Class II malocclusions. Amer. J. Orthodont. Dentofac. Orthop., v.108, n.1, p.62-8, July 1995. 
129 PONYI, S.; SZABÓ, G.; NYILASI, J. Asymmetry of mandibular dimensions in european skulls. Proc. Fin. dent. Soc., v.87, n.3, p.321-7, July 1991.

130 POSEN, A. L. Vertical height of the body of the mandible and the occlusal level of the teeth in individuals with cleft and non-cleft palates. J. calif. dent. Ass., p.211-8, 1958.

131 PROFFIT, W. R. Contemporary Orthodontics. Saint Louis, C. V. Mosby, 1986.

132 PROFFIT, W. R.; VIG, K. W. L.; TURVEY, T. A. Early fracture of the mandibular condyles: Frequently and unsuspected cause of growth disturbances. Amer. J. Orthodont. Dentofac. Orthop., v.78, n.1, p.1-24, July 1980.

133 PULLINGER, A. G. et al. Relationship of mandibular condylar position to dental occlusion factors in an asymptomatic population. Amer. $\mathbf{J}$. Orthodont. Dentofac. Orthop., v.91, n.3, p.200-6, Mar. 1987.

134 REBELLATO, J. Asymmetric extractions used in the treatment of patients with asymmetries. Seminars in Orthodontics, v.4, n.3, p.180-8, Sept. 1998.

135 RICHARDSON, A. A comparision of traditional and computadorized method of cephalometric analysis. Europ. J. Orthodont., v.3, p.15-20, 1981.

136 RITUCCI, R.; BURSTONE, C. J. Use of the submental vertical radiograph in the assessment of asymmetry. Farmington, 1981. Certificate in Orthodontics - Department of Orthodontics, University of Connecticut apud ARNOLD, T. G.; LILYEMARK, W. F 5 .

137 ROSE, J. M. et al. Mandibular skeletal and dental asymmetry in Class II subdivision malocclusions. Amer. J. Orthodont. Dentofac. Orthop., v.105, n.5, p.489-95, May 1994. 
138 ROSEN, M. D.; BUTCHER, E. O.; SILVERMAN, S. I. Muscle and skull development changes in dogs with induced unilateral anodontia. Oral Surg., v.3, p.672-5, Nov. 1965.

139 ROTH, R. H. Functional occlusion for the orthodontist. Part 1. J. clin. Orthodont., v.15, n.1, p.32-51, Jan. 1981.

140 RUNE, B. et al. Roentgen stereometry with the aid of metallic implants in hemifacial microsomia. Amer. J. Orthodont. Dentofac. Orthop., v.84, n.8, p.231-47, Sept. 1983.

141 SARNAS, K. V. et al. Hemifacial microssomia treated with the Herbst appliance: report of a case analysed by means of roentgenstereometry and metallic implants. Amer. J. Orthodont. Dentofac. Orthop., v.82, n.1, p.6874 , July 1982.

142 SASSOUNI, V. Position of the maxillary permanent first molar in the cephalofacial complex: a study in three dimensions. Amer. J. Orthodont., v.43, n.7, p.447-510, July 1957.

143 SCAVONE JÚNIOR, H. O perfil facial tegumentar dos 13 aos 18 anos de idade: estudo cefalométrico longitudinal em jovens brasileiros leucodermas, com oclusão normal. Bauru, 1996. 217p. Tese (Doutorado) - Faculdade de Odontologia de Bauru, Universidade de São Paulo.

144 SCHEllhas, K. P.; POLLEI, S. R.; WILKES, C. H. Pediatric internal derangements of the temporomandibular joint: effect on facial development. Amer. J. Orthodont. Dentofac. Orthop., v.104, n.1, p.51-9, July 1993.

145 SCHMID, W.; MONGINI, F.; FELISIO, A. A computer-based assessment of structural and displacement asymmetries of the mandible. Amer. $\mathbf{J}$. Orthodont. Dentofac. Orthop., v.100, n.1, p.19-34, July 1991.

146 SCHUDY, F. F. Treatment of adult midline deviation by condilar repositioning. J. clin. Orthodont., v.30, n.6, p.343-7, June 1996. 
147 SCHUELLER, A. Die Schaedelbasis in Roentgenbild. Fortschr. Geb. Roentgenstr., v.11, 1905 apud JANSON, G. R. P. ${ }^{73}$ p.58.

148 SEVERT, T. R.; PROFFIT, W. R. The prevalence of facial asymmetry in the dentofacial deformities population at the University of North Carolina. Int. J. Adult. Orthodont. Orthognat. Surg., v.12, n.3, p.171-6, 1997.

149 - Postsurgical stability folowing correction of severe facial asymmetry. Int. J. Adult. Orthodont. Orthognat. Surg., v.12, n.4, p.25161, 1997.

150 SIMONS, M. E.; JOONDEPH, D. R. Change in overbite: a ten-year postretention study. Amer. J. Orthodont., v.64, n.4, p.349-67, Oct. 1973.

151 SHAH, S. M.; JOSHI, M. R. An assessment of asymmetry in the normal craniofacial complex. Angle Orthodont., v.48, n.2, p.141-7, Apr. 1978.

152 SHAW, W. C. et al. The influence of dentofacial appearance on the social attractiveness of young adults. Amer. J. Orthodont. Dentofac. Orthop., v.87, n.1, p.21-6, Jan. 1985.

153 SHEATS, R. D. et al. Prevalence of orthodontic asymmetries. Seminars in Orthodontics, v.4, n.3, p.138-45, Sept. 1998.

154 SHORE, I. L. A cephalometric study of facial symmetry. Pittsburgh, 1959. Master's Thesis - University of Pittsburgh.

155 SHROFF, B.; SIEGEL, S. M. Treatment of patients with asymmetries using asymmetric mechanics. Seminars in Orthodontics, v.4, n.3, p.165-79, Sept. 1998.

156 SHROFF, B.; LINDAUER, S. J.; BURSTONE, C. J. Class II subdivision treatment with tip-back moments. Europ. J. Orthodont., v.19, n.1, p.93101, Feb. 1997. 
157 SHROFF, B. et al. Segmented approach to simultaneous intrusion and space closure: biomechanics of the three-piece base arch appliance. Amer. J. Orthodont. Dentofac. Orthop., v.107, n.2, p.136-43, Feb. 1995.

158 SINCLAIR, P. M. The reader's corner. J. clin. Orthodont., v.27, n.4, p.221-3, Apr. 1993.

159 SJURSEN, R. C.; LEGAN, H. L.; WERTHER, J. R. Case report: assessment, documentation and treatment of a development facial asymmetry following early childhood injury. Angle Orthodont., v.69, n.1, p.89-94, Feb. 1999.

160 SKOLNICK, J. et al. Prepubertal trauma and mandibular asymmetry in orthognathic surgery and orthodontic patients. Amer. J. Orthodont. Dentofac. Orthop., v.105, n.1, p.73-7, Jan. 1994.

161 SLAVICEK, R. JCO Interviews: on clinical and instrumental functional analysis for diagnosis and treatment planning (Part 1). J. clin. Orthodont., v.22, n.6, p.358-70, June 1988.

162 STAGGERS, J. A. Vertical changes folowing first premolar extractions. Amer. J. Orthodont. Dentofac. Orthop., v.105, n.1, p.19-24, Jan. 1994.

163 STRANG, R.; THOMPSON, W. A textbook of orthodontia. Philadelphia. Lea \& Febiger, 1958 apud JERROLD, L.; LOWENSTEIN, L. J. ${ }^{77}$ p.457.

164 SUTTON, P. R. N. Lateral facial asymmetry - methods of assessment. Angle Orthodont., v.38, n.1, p.82-92, Jan. 1968.

165 SVED, A. An analysis of the most important diagnostic methods used in orthodontia. Angle Orthodont., v.1, p.139-60, 1931.

166 TALLENTS, R. H. et al. Angular and linear comparisions with unilateral mandibular asymmetry. J. craniomandibular dis. fac. oral pain, v.5, n.2, p.135-41, May 1991. 
167 TERRY, H. K. The labiolingual appliance. Amer. J. Orthodont., v.55, p.16887, 1969.

168 TODD, M. et al. Asymmetric extraction treatment of a Class II, division 1, subdivision left malocclusion with anterior and posterior crossbites. Amer. J. Orthodont. Dentofac. Orthop., v.115, n.4, p.410-17, Apr. 1999.

169 UNITED States Departament of Health Education and Welfare. An assessment of the occlusion of the teeth of youths 12-17 years. Rockville, Maryland, United States. National Center for Health Statistics, 1977.

170 VAN SICKELS, J. E.; LARSEN, A. J.; THRASH, W. J. A retrospective study of relapse in rigidity fixated sagital split osteotomies: contributing factors. Amer. J. Orthodont. Dentofac. Orthop., v.93, n.5, p.413-8, May 1988.

171 VARGERVIK, K. Mandibular malformations: growth characteristics and management in hemifacial microssomia and Nager syndrome. Acta odont. scand., v.56, n.6, p.331-8, Dec. 1998.

172 VIG, P. S.; HEWITT, A. B. Asymmetry of the human facial skeleton. Angle Orthodont., v.45, n.2, p.124-9, Apr. 1975.

173 WERTZ, R. A. Diagnosis and treatment planning of unilateral Class II malocclusion. Angle Orthodont., v.45, n.2, p.85-94, Apr. 1975.

174 WESTESSON, P. L. et al. Radiographic assessment of asymmetry of the mandible. Amer. J. Neuroradiol., v.15, p.991-9, 1994.

175 WHITE, J. C. A study of craniofacial asymmetry. Cleveland, 1982. Case Western University.

176 WILKINSON, L. et al. Systat for windows: statistics. 5. ed. Evanston II, 1992. p.750. 
177 WILLIAMSON, E. H. JCO interviews: on occlusion and TMJ dysfunction (Part 1). J. clin. Orthodont., v.15, n.5, p.333-50, May 1981.

178 WILLIAMSON, E. H. JCO interviews: on occlusion and TMJ dysfunction (Part 2). J. clin. Orthodont., v.15, n.6, p.393-410, June 1981.

179 WILLIAMSON, E. H.; SIMMONS, M. D. Mandibular asymmetry and its relation to pain dysfunction. Amer. J. Orthodont., v.76, n.6, p.612-17, Dec. 1979.

180 WILLIAMSON, E. H.; WILSON, C. W. Use of a submentatvertex analysis for producing quality temporomandibular joint laminagraphs. Amer. J. Orthodont. Dentofac. Orthop., v.70, n.2, p.200-7, Aug. 1976.

181 WOHL, T. S.; BAMONTE, E.; PEARSON, H. E. Nonextraction treatment of unilateral Class II, division 1 malocclusion with asymmmetric headgear. Amer. J. Orthodont. Dentofac. Orthop., v.113, n.5, p.483-7, May 1998.

182 WOO, T. L. On the asymmetry of the human skull. Biometrika, v.22, p.324-41, 1931.

183 WOODSIDE, D. G. The diagnosis and treatment of mandibular asymmetry. University of Toronto, Department of continuing education, 1990 apud GIAMBATISTTINI, C. ${ }^{48}$ p.46.

184 WOODSIDE, D. G. A serial study of mandibular growth - accelerations in a large population of canadian males and females aged three to twenty years. In: HOSL, E.; BALDALF, A. Mechanical and biological basis in orthodontic therapy. Heidelberg, Huthig, 1991.

185 YAMASHIRO, T.; OKADA, T.; TAKADA, K. Case report: facial asymmetry and early condylar fracture. Angle Orthodont., v.68, n.1, p.85-90, Feb. 1998. 


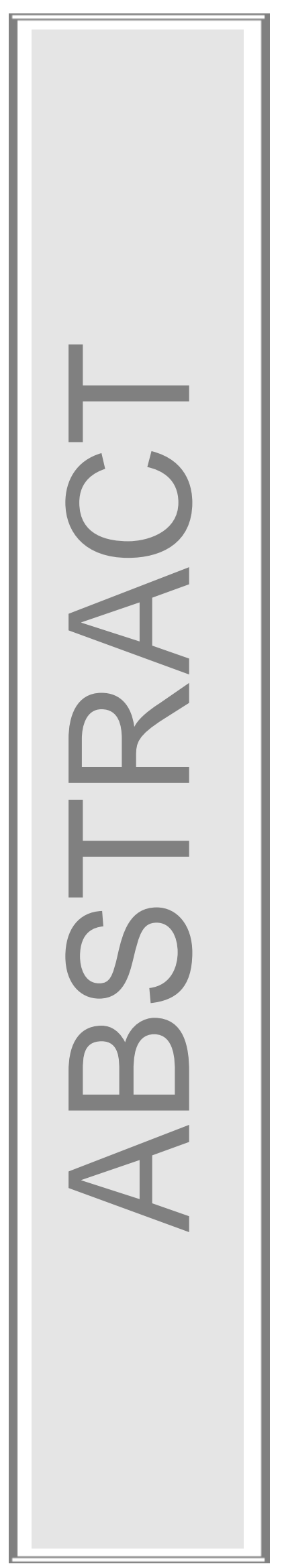




\section{ABSTRACT}

\section{"Evaluation of dentoskeletal treatment changes in Class II, subdivision}

\section{malocclusion in the submentovertex and posteroanterior radiographs"}

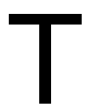

he objective of this work was to evaluate the dentoskeletal changes consequent to orthodontic treatment in subjects with Angle's Class II subdivision malocclusions, treated with asymmetric extractions, as compared to a normal occlusion control group. The sample consisted of three groups, with 30 subjects in each: group 1 consisted of untreated Class II, subdivision subjects; group 2 had Class II, subdivision subjects after treatment with asymmetric extractions and group 3 consisted of normal occlusion subjects. All possessed a full complement of permanent teeth including first molars, at the beginning of treatment. The average age of subjects was 15.76, 18.57 and 22.42 years in the untreated, in the treated Class II, subdivision groups and in the normal occlusion group, respectively. Measurements of relative difference in spatial position of dental and skeletal bilateral landmarks were obtained from the submentovertex and posteroanterior cephalometric radiographs. The t test for independent samples was used to compare groups 1 and 2 with group 3 at different times. Group 2 was considered to have experienced an improvement if the variables of group 1 that had a statistically significant difference with group 3 were not statistically different from the normal occlusion control sample. Results in the submentovertex radiograph demonstrated that asymmetric extractions in Class II, subdivision malocclusions will accentuate the differences in the anteroposterior positions of right and left, upper and lower first molars, as would be expected with this treatment protocol. There were no significant skeletal changes that could be attributed to the treatment approaches investigated nor transversal colateral effects with the asymmetric mechanics employed. It was also demonstrated that treatment of Class II, subdivision malocclusions with asymmetric extractions produced corrections of upper and lower dental midline deviations with the midsaggital line, without canting the occlusal plane as well as any other investigated horizontal plane, in the PA radiograph. Therefore, it was concluded that treatment of Class II, subdivision malocclusions with asymmetric extractions constitute a beneficial approach to this problem. 


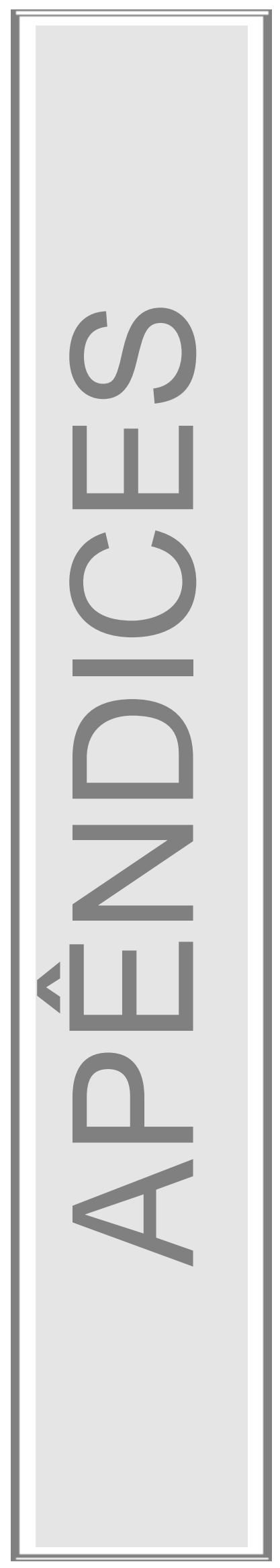




\section{APÊNDICES}

Tabela A - 1 - Características dos pacientes dos grupos de oclusão normal e de Classe II, subdivisão, tratado

\begin{tabular}{|c|c|c|c|c|c|}
\hline \multicolumn{6}{|c|}{ OCLUSÃO NORMAL } \\
\hline Paciente & DN & Data Rx & Idade & Direito & Esquerdo \\
\hline 1- A. C. J.P. & 27.02 .67 & 26.10 .95 & 28,67 & Relação normal & Relação normal \\
\hline 2- A. C. M. & 16.05 .81 & 18.06 .96 & 15,10 & Relação normal & Relação normal \\
\hline 3- A. E. A. & 09.04 .74 & 08.04 .96 & 22,01 & Relação normal & Relação normal \\
\hline 4- A. T. N. & 27.10 .80 & 31.08 .96 & 15,85 & Relação normal & Relação normal \\
\hline 5- A. C. R. & 30.10 .75 & 10.08 .96 & 20,79 & Relação normal & Relação normal \\
\hline 6- A. M. K. & 08.07 .76 & 10.08 .96 & 20,10 & Relação normal & Relação normal \\
\hline 7- C. A. C. & 25.05 .77 & 28.06 .96 & 19,10 & Relação normal & Relação normal \\
\hline 8- C.F. & 15.07 .68 & 25.04 .95 & 26,79 & Relação normal & Relação normal \\
\hline 9- C. J. C. & 20.08 .80 & 26.10 .95 & 15,19 & Relação normal & Relação normal \\
\hline 10- D. S. M. & 01.12 .79 & 13.07 .96 & 16,62 & Relação normal & Relação normal \\
\hline 11- D. A. A. & 08.04 .73 & 24.08 .96 & 23,39 & Relação normal & Relação normal \\
\hline 12- F. Y. & 25.08 .75 & 24.08 .96 & 21,01 & Relação normal & Relação normal \\
\hline 13- F. G. A. & 30.08 .69 & 30.03 .96 & 26,60 & Relação normal & Relação normal \\
\hline 14- F. P. A. Jr. & 13.11 .72 & 10.08 .96 & 23,75 & Relação normal & Relação normal \\
\hline 15- H.F.S. & 19.02 .80 & 21.11 .95 & 15,76 & Relação normal & Relação normal \\
\hline 16- J.R.P. & 27.07 .78 & 21.03 .96 & 17,66 & Relação normal & Relação normal \\
\hline 17- J. K. & 24.06 .75 & 13.04 .96 & 20,81 & Relação normal & Relação normal \\
\hline 18- J. LD. & 30.06 .76 & 20.04 .96 & 19,81 & Relação normal & Relação normal \\
\hline 19- L. M. C. & 15.04 .72 & 04.06 .96 & 24,15 & Relação normal & Relação normal \\
\hline 20- M. R. F. & 17.12 .75 & 16.03 .96 & 20,26 & Relação normal & Relação normal \\
\hline 21- M. C. R. M. & 14.04 .76 & 01.06 .96 & 20,14 & Relação normal & Relação normal \\
\hline 22- M. H. D. & 16.03 .55 & 28.03 .96 & 41,06 & Relação normal & Relação normal \\
\hline 23- M. F. & 12.08 .72 & 19.04 .96 & 23,70 & Relação normal & Relação normal \\
\hline 24- N. Z. V. & 13.12 .63 & 20.10 .95 & 31,87 & Relação normal & Relação normal \\
\hline 25- R. T. & 03.10 .71 & 20.10 .95 & 24,06 & Relação normal & Relação normal \\
\hline 26- R. P. & 02.05 .65 & 01.06 .96 & 31,10 & Relação normal & Relação normal \\
\hline 27- R. B. F. A. & 24.09 .71 & 24.08 .96 & 24,93 & Relação normal & Relação normal \\
\hline 28- S. H. & 19.01 .73 & 16.03 .96 & 23,16 & Relação normal & Relação normal \\
\hline 29- S. B. & 02.05 .77 & 28.06 .96 & 19,16 & Relação normal & Relação normal \\
\hline 30- V. A. R. F. & 28.01 .76 & 25.04 .96 & 20,25 & Relação normal & Relação normal \\
\hline \multirow{2}{*}{\multicolumn{6}{|c|}{ CLASSE II, SUBDIVISÃO, TRATADO }} \\
\hline & & & & & \\
\hline Paciente & DN & Data Rx & Idade & Direito & Esquerdo \\
\hline 1-A. O. B. & $14 / 08 / 83$ & 29/01/99 & 15,47 & CLASSE I & CLASSE ॥ \\
\hline 2-A. E. & 19/03/81 & 03/12/98 & 17,69 & CLASSE I & CLASSE ॥ \\
\hline 3-A. N. P. M. & $12 / 07 / 80$ & 20/01/99 & 18,53 & CLASSE I & CLASSE II \\
\hline 4-A. B. S. & $09 / 04 / 73$ & 05/06/99 & 17,61 & CLASSE ॥ & CLASSE I \\
\hline 5-A. P. M. C. & $29 / 04 / 81$ & 04/12/98 & 14,13 & CLASSE I & CLASSE II \\
\hline 6-A.P. S. R. & 19/10/84 & $04 / 12 / 98$ & 26,17 & CLASSE I & CLASSE ॥ \\
\hline 7-A. C. M. Jr. & $05 / 11 / 83$ & 04/12/98 & 15,09 & CLASSE I & CLASSE II \\
\hline 8-B.S .R. M. & $14 / 05 / 84$ & 08/02/99 & 14,74 & CLASSE I & CLASSE ॥ \\
\hline 9-C. R. S. B. & 03/09/78 & 21/01/99 & 20,39 & CLASSE ॥ & CLASSE I \\
\hline 10-C. J.S. & $02 / 12 / 78$ & 04/12/98 & 19,98 & CLASSE I & CLASSE ॥ \\
\hline 11-C. R. M. & $02 / 05 / 76$ & $25 / 01 / 99$ & 22,74 & CLASSE ॥ & CLASSE I \\
\hline 12-D. C. M. G. & $26 / 03 / 83$ & 26/02/99 & 15,93 & CLASSE I & CLASSE II \\
\hline 13-D. J. S. & $29 / 01 / 80$ & 08/02/99 & 19,04 & CLASSE I & CLASSE II \\
\hline 14-D. C. & $22 / 07 / 84$ & 12/04/99 & 14,73 & CLASSE I & CLASSE II \\
\hline 15-E. P. & 03/03/81 & 29/03/99 & 18,08 & CLASSE II & CLASSE I \\
\hline 16-E. F. S. & $03 / 07 / 83$ & $02 / 12 / 98$ & 15,40 & CLASSE ॥ & CLASSE I \\
\hline 17-F. G.P. & 28/12/76 & 10/05/99 & 22,37 & CLASSE I & CLASSE II \\
\hline 18-F. N. S. A. & $09 / 11 / 72$ & $12 / 05 / 99$ & 26,52 & CLASSE ॥ & CLASSE I \\
\hline 19-J. F. A. N. & $12 / 06 / 83$ & 09/02/99 & 15,67 & CLASSE II & CLASSE I \\
\hline 20-M. A. O. F. & $26 / 09 / 81$ & 27/01/99 & 17,34 & CLASSE II & CLASSE I \\
\hline 21-M. M. S. & 01/08/82 & 28/01/99 & 16,50 & CLASSE II & CLASSE I \\
\hline 22-М. С. М. & $03 / 04 / 80$ & $30 / 11 / 98$ & 18,67 & CLASSE II & CLASSE I \\
\hline 23-М. С. C. & $31 / 10 / 81$ & 07/12/98 & 17,11 & CLASSE II & CLASSE I \\
\hline 24-P. A. R. & $26 / 07 / 82$ & 22/03/99 & 16,66 & CLASSE II & CLASSE I \\
\hline 25-R. G. & $22 / 03 / 80$ & 28/01/99 & 18,86 & CLASSE II & CLASSE I \\
\hline 26-R. M. G. & $04 / 05 / 83$ & 21/01/99 & 15,72 & CLASSE ॥ & CLASSE I \\
\hline 27-R. M. P. & $25 / 05 / 72$ & 22/01/99 & 26,67 & CLASSE II & CLASSE I \\
\hline 28-R. C. M. & $07 / 01 / 79$ & 21/01/99 & 20,05 & CLASSE I & CLASSE ॥ \\
\hline 29-S. A. P. & $30 / 01 / 76$ & 03/12/98 & 22,85 & CLASSE I & CLASSE II \\
\hline 30-W. R. D. & $15 / 07 / 82$ & 22/01/99 & 16,53 & CLASSE I & CLASSE II \\
\hline Média: & & & 18,57 & & \\
\hline
\end{tabular}


As tabelas A - 2 a A - 15 referem-se aos valores reais individuais de cada variável, para cada paciente, dos grupos de oclusão normal e de Classe II, subdivisão, tratado

Tabela A - 2

\begin{tabular}{|c|c|c|c|c|c|c|c|}
\hline & & & & USAO NOF & $\mathbf{A L}$ & & \\
\hline Paciente & Número & Grupo & Sexo & GO-ETC & PPC-ETC & PDMI-ETC & PDMS-ETC \\
\hline 1-A. C. J.P. & 1 & 2 & $\mathrm{~F}$ & 0,2 & $-1,3$ & $-1,1$ & $-0,8$ \\
\hline 2- A. C. M. & 2 & 2 & $\mathrm{~F}$ & 1,5 & 0,3 & 2,5 & 2,9 \\
\hline 3-A. E. A. & 3 & 2 & $\mathrm{~F}$ & 0,8 & 0,4 & 1,5 & 0,9 \\
\hline 4- A. T. N. & 4 & 2 & $\mathrm{~F}$ & $-1,4$ & $-0,8$ & $-2,0$ & $-1,6$ \\
\hline 5-A. C. R. & 5 & 2 & $\mathrm{~F}$ & 0,1 & 1,0 & $-1,2$ & $-1,4$ \\
\hline 6- A. M. K. & 6 & 2 & $\mathrm{~F}$ & $-2,5$ & $-0,2$ & 0,2 & $-0,6$ \\
\hline 7- C. A. C. & 7 & 2 & $\mathrm{~F}$ & 0,4 & $-3,5$ & $-0,4$ & 0,3 \\
\hline 8- C. F. & 8 & 2 & $\mathrm{M}$ & 0,0 & $-1,6$ & 1,8 & 0,9 \\
\hline 9- C. J. C. & 9 & 2 & $\mathrm{~F}$ & $-0,3$ & $-2,0$ & $-1,2$ & $-1,8$ \\
\hline 10- D. S. M. & 10 & 2 & $M$ & $-3,6$ & $-1,5$ & 0,9 & 0,1 \\
\hline 11- D. A. A. & 11 & 2 & $\mathrm{~F}$ & 0,0 & 0,7 & $-0,7$ & $-0,3$ \\
\hline 12- F.Y. & 12 & 2 & M & 0,0 & $-2,7$ & $-1,8$ & $-1,9$ \\
\hline 13- F. G. A. & 13 & 2 & $\mathrm{~F}$ & 0,1 & 1,2 & 0,0 & 0,7 \\
\hline 14- F.P. A. Jr. & 14 & 2 & $\mathrm{M}$ & $-1,2$ & 0,1 & $-0,6$ & 0,0 \\
\hline 15-H.F.S. & 15 & 2 & $\mathrm{~F}$ & 1,4 & 0,8 & 0,9 & 1,9 \\
\hline 16-J.R.P. & 16 & 2 & $\mathrm{M}$ & 2,7 & 2,5 & 1,6 & 1,1 \\
\hline 17- J.K. & 17 & 2 & $M$ & $-2,1$ & $-1,7$ & $-2,0$ & $-2,4$ \\
\hline 18- J. L D. & 18 & 2 & $\mathrm{~F}$ & 3,3 & $-2,4$ & $-0,4$ & $-0,6$ \\
\hline 19- L. M. C. & 19 & 2 & $\mathrm{~F}$ & 0,1 & $-1,5$ & 0,2 & $-0,3$ \\
\hline 20-M.R. F. & 20 & 2 & M & $-3,7$ & 0,3 & $-0,9$ & $-1,1$ \\
\hline 21- M. C. R. M. & 21 & 2 & $\mathrm{~F}$ & 0,0 & $-1,2$ & 0,5 & 0,2 \\
\hline 22- M. H. D. & 22 & 2 & $\mathrm{~F}$ & $-0,3$ & $-0,7$ & $-0,8$ & 0,7 \\
\hline 23- M. F. & 23 & 2 & $\mathrm{~F}$ & $-3,1$ & 1,6 & 0,2 & 0,1 \\
\hline 24- N. Z. V. & 24 & 2 & $M$ & $-0,5$ & 0,5 & 1,5 & 2,0 \\
\hline 25-R. T. & 25 & 2 & M & 1,9 & 1,0 & 0,4 & 0,8 \\
\hline 26-R.P. & 26 & 2 & M & 2,8 & 1,0 & 1,1 & 0,6 \\
\hline 27- R. B. F. A. & 27 & 2 & $\mathrm{~F}$ & $-0,1$ & 1,5 & $-0,5$ & $-0,4$ \\
\hline 28- S. H. & 28 & 2 & $\mathrm{~F}$ & $-0,8$ & $-0,7$ & 0,5 & 1,0 \\
\hline 29- S. B. & 29 & 2 & $\mathrm{~F}$ & 1,4 & 2,4 & 1,2 & 0,6 \\
\hline 30- V. A. R. F. & 30 & 2 & $\stackrel{F}{F}$ & $-0,2$ & $-2,5$ & 0,3 & $-1,0$ \\
\hline & & & CLASSE & UBDIVISÃ & TRATADO & & \\
\hline Paciente & Número & Grupo & Sexo & GO-ETC & PPC-ETC & PDMI-ETC & PDMS-ETC \\
\hline 1-A. O. B. & 31 & 1 & $M$ & $-1,3$ & 2,4 & 5,4 & -1 \\
\hline 2-A. E. & 32 & 1 & $\mathrm{~F}$ & 2,7 & 6,1 & 7,3 & $-1,6$ \\
\hline 3-A. N. P. M. & 33 & 1 & $\mathrm{~F}$ & $-0,5$ & 1,9 & 3,6 & $-1,7$ \\
\hline 4-A. B. S. & 34 & 1 & $F$ & $-0,6$ & 0,1 & 2 & $-4,2$ \\
\hline 5-A. P. M. C. & 35 & 1 & $\mathrm{~F}$ & 1,6 & $-0,6$ & 6,3 & $-1,1$ \\
\hline 6-A. P. S. R. & 36 & 1 & $\mathrm{~F}$ & 1,1 & 0,7 & 2,8 & -5 \\
\hline 7-A. C. M. Jr. & 37 & 1 & M & $-4,1$ & $-3,2$ & -2 & $-6,1$ \\
\hline 8-B. S .R. M. & 38 & 1 & M & 3,5 & $-0,9$ & 7,2 & 0,1 \\
\hline 9-C. R. S. B. & 39 & 1 & $\mathrm{M}$ & $-2,1$ & $-3,7$ & 6,2 & $-3,4$ \\
\hline 10-C. J. S. & 40 & 1 & $\mathrm{~F}$ & $-0,7$ & 2 & 8,5 & 0,1 \\
\hline 11-C. R. M. & 41 & 1 & $\mathrm{~F}$ & $-1,4$ & $-1,7$ & 7,2 & $-0,7$ \\
\hline 12-D. C. M. G. & 42 & 1 & $M$ & 1,4 & 3,9 & 6,4 & $-0,5$ \\
\hline 13-D. J. S. & 43 & 1 & $M$ & $-1,1$ & $-2,6$ & 2,9 & $-3,6$ \\
\hline 14-D. C. & 44 & 1 & $\mathrm{~F}$ & 4,1 & 4,1 & 7,8 & 2 \\
\hline 15-E. P. & 45 & 1 & $\mathrm{~F}$ & $-1,1$ & 0,7 & 5 & $-0,3$ \\
\hline 16-E. F.S. & 46 & 1 & $\mathrm{~F}$ & 0,6 & 3,6 & 4,7 & $-0,7$ \\
\hline 17-F. G. P. & 47 & 1 & $\mathrm{M}$ & 0,6 & 1,1 & -1 & $-4,5$ \\
\hline 18-F. N. S. A. & 48 & 1 & $\mathrm{~F}$ & $-2,3$ & 2,1 & $-0,8$ & $-8,2$ \\
\hline 19-J. F. A. N. & 49 & 1 & $M$ & 1,3 & $-1,8$ & 4,2 & $-3,3$ \\
\hline 20-M. A. O. F. & 50 & 1 & $M$ & 0,6 & 0,1 & 1,5 & $-5,6$ \\
\hline 21-M. M. S. & 51 & 1 & $\mathrm{~F}$ & $-1,8$ & $-0,1$ & $-1,1$ & -5 \\
\hline 22-M. C. M. & 52 & 1 & $\mathrm{~F}$ & $-0,1$ & 0,6 & 2,7 & $-1,9$ \\
\hline 23-M. С. C. & 53 & 1 & $\mathrm{~F}$ & $-0,5$ & $-1,8$ & $-0,3$ & $-4,3$ \\
\hline 24-P. A. R. & 54 & 1 & $\mathrm{~F}$ & 0,3 & 0,1 & 1,9 & $-3,4$ \\
\hline 25-R. G. & 55 & 1 & $\mathrm{M}$ & $-1,1$ & $-1,4$ & 0,4 & $-5,1$ \\
\hline 26-R. M. G. & 56 & 1 & $M$ & 0,8 & 1,1 & 0,4 & $-5,9$ \\
\hline 27-R. M. P. & 57 & 1 & $\mathrm{~F}$ & $-1,1$ & 1,4 & 3,9 & $-0,6$ \\
\hline 28-R. C. M. & 58 & 1 & $\mathrm{M}$ & 0,4 & 0 & 1,5 & $-3,7$ \\
\hline 29-S. A. P. & 59 & 1 & $\mathrm{~F}$ & $-0,2$ & $-0,5$ & -1 & $-6,8$ \\
\hline 30-W. R. D. & 60 & 1 & $M$ & 0,3 & 1,7 & 2,2 & $-3,2$ \\
\hline
\end{tabular}


Tabela A - 3

\begin{tabular}{|c|c|c|c|c|c|c|c|}
\hline & & & DCLUSÃO N & ORMAL & & & \\
\hline Nome paciente & GO-EIC & PPC-EIC & PDMI-EIC & PDMS-EIC & LMM-EIC & LMDI-EIC & LMDS-EIC \\
\hline 1-A. C. J.P. & 4,9 & 0,3 & 3,6 & 2,6 & 1,7 & 1,6 & 1,9 \\
\hline 2- A. C. M. & 3,7 & 0,3 & 0,7 & 2,0 & $-0,2$ & $-0,2$ & $-0,4$ \\
\hline 3- A. E. A. & 1,3 & 1,4 & $-1,9$ & $-0,8$ & $-0,4$ & $-0,5$ & 0,0 \\
\hline 4- A. T. N. & 2,0 & 6,1 & 8,4 & 7,8 & 4,4 & 5,5 & 4,4 \\
\hline 5- A. C. R. & 0,4 & 2,5 & 1,8 & 1,6 & 2,7 & 2,3 & 2,1 \\
\hline 6- A. M. K. & 2,8 & 2,0 & 3,2 & 3,9 & 1,1 & 1,5 & 2,3 \\
\hline 7- C. A. C. & 0,2 & $-4,5$ & $-1,0$ & $-0,3$ & $-0,4$ & $-0,2$ & 0,1 \\
\hline 8- C. F. & $-0,7$ & $-0,6$ & $-0,9$ & $-0,6$ & $-0,8$ & $-0,6$ & $-0,9$ \\
\hline 9- C. J. C. & $-1,0$ & 3,6 & 2,3 & 3,7 & 2,3 & 2,3 & 1,9 \\
\hline 10- D. S. M. & 1,3 & $-1,6$ & 0,6 & 1,3 & 0,6 & 0,5 & 0,9 \\
\hline 11- D. A. A. & $-0,3$ & $-1,0$ & 2,9 & 2,7 & 3,5 & 1,5 & 1,6 \\
\hline 12- F. Y. & 2,3 & 2,8 & 4,4 & 3,9 & 1,5 & 2,9 & 3,1 \\
\hline 13- F. G. A. & $-1,5$ & $-3,3$ & $-5,1$ & $-3,8$ & $-2,6$ & $-2,3$ & $-1,8$ \\
\hline 14- F. P. A. Jr. & 2,6 & 2,3 & 3,3 & 2,4 & 1,1 & 1,6 & 1,2 \\
\hline 15- H. F.S. & 0,7 & 3,9 & 2,2 & 2,2 & 2,1 & 1,6 & 1,0 \\
\hline 16- J.R.P. & 2,1 & $-6,1$ & $-4,4$ & $-4,1$ & $-2,5$ & $-2,6$ & $-2,8$ \\
\hline 17- J. K. & 0,6 & $-3,9$ & $-3,7$ & $-3,1$ & $-1,4$ & $-2,2$ & $-1,1$ \\
\hline 18- J. LD. & $-2,2$ & $-0,5$ & $-0,4$ & 0,2 & 1,7 & 1,6 & 0,6 \\
\hline 19- L. M. C. & $-0,8$ & $-2,3$ & $-2,3$ & $-3,0$ & $-1,9$ & $-0,5$ & $-2,3$ \\
\hline 20-M.R. F. & $-4,3$ & 0,0 & $-3,3$ & $-1,8$ & $-2,0$ & $-1,5$ & $-0,4$ \\
\hline 21- M. C. R. M. & $-1,8$ & $-2,2$ & $-1,7$ & $-2,1$ & $-1,3$ & $-1,2$ & $-1,2$ \\
\hline 22- M. H. D. & 0,7 & 1,9 & 1,5 & 1,5 & 0,1 & 1,0 & 0,0 \\
\hline 23- M. F. & 2,5 & $-0,4$ & 2,4 & 2,4 & 0,2 & 1,7 & 1,6 \\
\hline 24- N. Z. V. & 2,5 & 4,9 & 6,3 & 6,1 & 3,1 & 2,9 & 3,3 \\
\hline 25- R. T. & $-4,4$ & $-6,3$ & $-8,3$ & $-7,3$ & $-7,0$ & $-4,7$ & $-3,9$ \\
\hline 26- R. P. & $-3,0$ & $-2,9$ & $-3,3$ & $-2,5$ & $-4,1$ & $-2,9$ & $-1,8$ \\
\hline 27-R. B. F. A. & 2,9 & 1,1 & 1,7 & 1,5 & 0,7 & 0,6 & 0,9 \\
\hline 28- S. H. & 2,1 & $-1,6$ & $-2,3$ & $-1,5$ & $-1,4$ & 0,3 & $-1,1$ \\
\hline 29- S. B. & 1,6 & $-2,4$ & $-0,6$ & $-1,1$ & $-0,8$ & $-0,8$ & $-0,3$ \\
\hline 30- V. A.R. F. & $-1,4$ & $-4,7$ & $-3,8$ & $-3,0$ & $-3,0$ & $-2,1$ & $-1,8$ \\
\hline & & CLASS & II, SUBDIVI & ÃO, TRATA & & & \\
\hline Nome paciente & GO-EIC & PPC-EIC & PDMI-EIC & PDMS-EIC & LMM-EIC & LMDI-EIC & LMDS-EIC \\
\hline 1-A. О. В. & 1,2 & $-0,6$ & $-4,2$ & $-0,5$ & $-4,4$ & $-5,9$ & $-5,8$ \\
\hline 2-A. E. & 5,2 & $-2,8$ & 4,6 & 4,2 & $-1,9$ & $-2,7$ & $-2,7$ \\
\hline 3-A. N. P. M. & 3,7 & $-0,2$ & $-0,5$ & 1,7 & $-2,3$ & $-2,3$ & $-2,6$ \\
\hline 4-A. B. S. & 1,2 & 4 & 9,9 & 6,9 & 0,2 & 1,9 & 1,6 \\
\hline 5-A. Р. M. C. & 3,2 & $-4,3$ & $-1,3$ & 1 & $-0,1$ & 0 & $-0,1$ \\
\hline 6-A. P. S. R. & 1,4 & -1 & -4 & $-3,5$ & $-1,1$ & $-2,7$ & $-2,7$ \\
\hline 7-A. C. M. Jr. & 1,2 & 1,6 & 3,6 & 6,3 & 3,5 & 3,9 & 3,2 \\
\hline 8-B. S .R. M. & $-4,5$ & 0,6 & 3,2 & 0,1 & $-0,4$ & $-0,2$ & $-0,5$ \\
\hline 9-C. R. S. B. & 0,4 & 2,9 & $-2,4$ & $-1,6$ & 0 & 0,4 & 0,3 \\
\hline 10-C. J. S. & 4,2 & 2,1 & 1,7 & 0,5 & 0,9 & 0,9 & 0,6 \\
\hline 11-C. R. M. & -3 & $-0,2$ & $-6,4$ & $-2,4$ & $-2,3$ & $-0,6$ & $-0,3$ \\
\hline 12-D. C. M. G. & 3,9 & 3,9 & 2,6 & 6,1 & 1,2 & 3,6 & 3,3 \\
\hline 13-D. J. S. & 0,6 & 1 & $-2,9$ & $-0,3$ & $-0,1$ & 3,2 & 3,4 \\
\hline 14-D. C. & $-0,5$ & $-2,7$ & $-8,7$ & $-4,1$ & -4 & -4 & $-3,6$ \\
\hline 15-E. P. & $-0,1$ & 0,8 & $-1,7$ & 0,1 & 0,1 & 0,4 & 0,6 \\
\hline 16-E. F.S. & $-0,3$ & $-2,6$ & $-7,9$ & $-5,2$ & -3 & $-0,6$ & $-1,2$ \\
\hline 17-F. G. P. & $-4,7$ & $-3,5$ & $-2,4$ & 3,1 & $-0,7$ & $-1,1$ & $-0,9$ \\
\hline 18-F. N. S. A. & 6,1 & 3,4 & 1,8 & 3 & 0,4 & 0,5 & 0,6 \\
\hline 19-J. F. A. N. & -1 & 1,5 & 0,1 & 4,3 & 4,2 & 4,7 & 4,5 \\
\hline 20-M. A. O. F. & 0 & $-0,8$ & $-0,3$ & 0,7 & 1,7 & $-1,1$ & $-0,5$ \\
\hline 21-M. M. S. & $-5,4$ & $-0,2$ & $-6,1$ & $-4,6$ & $-2,6$ & $-2,4$ & $-2,6$ \\
\hline 22-M. C. M. & $-3,7$ & 2,9 & $-6,6$ & $-4,8$ & $-5,7$ & $-1,2$ & $-1,5$ \\
\hline 23-M. C. C. & $-1,5$ & 3,6 & $-0,5$ & 4,5 & 0,3 & 0,3 & 0 \\
\hline 24-P. A. R. & $-1,9$ & 0,4 & $-4,8$ & $-3,2$ & $-2,9$ & -3 & -3 \\
\hline 25-R. G. & $-2,1$ & $-0,7$ & $-2,2$ & 0 & $-1,4$ & $-1,4$ & $-1,6$ \\
\hline 26-R. M. G. & $-6,4$ & -5 & $-2,6$ & 1 & $-1,3$ & $-1,6$ & $-1,6$ \\
\hline 27-R. M. P. & $-0,6$ & 1,9 & $-1,9$ & 2 & 0,3 & 3,1 & 2,1 \\
\hline 28-R. C. M. & 0,8 & 1,9 & 2,4 & 5,1 & 0,6 & 1,1 & 0,4 \\
\hline 29-S. A. P. & 1,5 & 3 & 2,5 & 3,3 & 1,1 & 1,1 & 0,6 \\
\hline 30-W. R. D. & $-3,3$ & 0,4 & $-6,7$ & -2 & -4 & -4 & $-3,1$ \\
\hline
\end{tabular}


Tabela A - 4

\begin{tabular}{|c|c|c|c|c|c|c|c|}
\hline & & & U & VURIVIA & & & \\
\hline Nome paciente & PCM-ETE & GO-ETE & PPC-ETE & PDMI-ETE & PDMS-ETE & ACP-ETE & FCM-ETE \\
\hline 1-A. C.J.P. & $-1,6$ & 1,6 & 0,2 & $-0,3$ & 0,1 & 1,5 & 2,3 \\
\hline 2-A. C. M. & $-1,2$ & 2,6 & 1,3 & 3,2 & 3,6 & 0,7 & 0,4 \\
\hline 3-A. E. A. & 1,6 & $-0,8$ & $-1,0$ & 0,8 & 0,1 & 0,0 & $-0,3$ \\
\hline 4-A.T.N. & $-2,8$ & 1.4 & 1,5 & $-0,6$ & -0.2 & $-0,3$ & 6.1 \\
\hline 5- A. C. R. & $-2,9$ & 2,9 & 3,7 & 0,3 & 0,1 & 0,1 & 2,6 \\
\hline 6- A. M. K. & $-1,8$ & $-0,7$ & 1,6 & 1,1 & 0,4 & $-0,1$ & 1,8 \\
\hline 7-C. A. C. & $-0,7$ & 1,1 & $-2,9$ & $-0,1$ & 0,7 & $-0,5$ & 1,8 \\
\hline 8- C. F. & $-0,6$ & 0,6 & $-1,0$ & 2,2 & 1,3 & 1,4 & 0,4 \\
\hline 9- C. J. C. & $-1,3$ & 1,0 & $-0,7$ & $-0,5$ & $-1,1$ & $-1,0$ & $-0,2$ \\
\hline 10- D. S. M. & $-3,6$ & $-0,1$ & 1,8 & 2,7 & 2,1 & $-1,5$ & 3,5 \\
\hline 11- D. A. A. & $-0,7$ & 0,7 & 1,4 & $-0,3$ & 0,1 & 0,3 & 2,8 \\
\hline 12- F. Y. & $-0,7$ & 0,6 & $-2,2$ & $-1,5$ & $-1,6$ & $-0,2$ & 0,3 \\
\hline 13- F. G. A. & $-2,0$ & 2,1 & 2,8 & 0,9 & 1,7 & $-0,8$ & $-2,2$ \\
\hline 14- F. P. A. Jr. & $-1,1$ & $-0,1$ & 1,1 & $-0,1$ & 0,6 & 3,1 & 0,3 \\
\hline 15-H.F.S. & $-0,9$ & 2,3 & 1,7 & 1,4 & 2,4 & 0,0 & 3,5 \\
\hline 16-J.R.P. & 2,3 & 0,4 & 0,3 & 0,4 & $-0,1$ & 0,8 & $-1,0$ \\
\hline 17- J.K. & $-3,0$ & 0,8 & 1,1 & $-0,5$ & $-0,9$ & 0,6 & $-2,1$ \\
\hline 18- J. LD. & $-2,2$ & 5,5 & -0.4 & 0.7 & 0.6 & -1.6 & 29 \\
\hline 19- L. M. C. & 0,2 & $-0,1$ & $-1,7$ & 0,1 & $-0,4$ & $-0,9$ & 0,5 \\
\hline 20-M. R. F. & $-5,6$ & 1,9 & 5,5 & 2,1 & 2,0 & $-1,5$ & 3,3 \\
\hline 21 - M. C. R. M. & 0,5 & $-0,4$ & $-1,6$ & 0,3 & $-0,1$ & 0,8 & 0,4 \\
\hline 22- M. H. D. & 0,0 & $-0,3$ & $-0,7$ & $-0,8$ & 0,7 & $-0,2$ & $-2,4$ \\
\hline 23- M. F. & 0,1 & $-3,2$ & 1,5 & 0,1 & 0,0 & 0,4 & $-0,7$ \\
\hline 24- N. Z. V. & 0,5 & $-1,1$ & 0,0 & 1,2 & 1,7 & $-1,3$ & 0,4 \\
\hline 25-R. T. & $-3,2$ & 5,0 & 3,9 & 1,9 & 2,4 & 0,3 & 2,2 \\
\hline 26- R.P. & $-0, \overline{7}$ & 3,5 & 1,7 & 1,4 & 1,0 & 0,8 & 0,8 \\
\hline 27-R. B. F. A. & 2,7 & $-2,7$ & $-1,0$ & $-1,8$ & $-1,8$ & $-1,9$ & $-1,0$ \\
\hline 28- S. H. & 0.0 & -0.8 & $-0,7$ & 0,5 & 1.0 & 14 & 2.5 \\
\hline 29- S. B. & $-2,0$ & 3,4 & 4,3 & 2,3 & 1,7 & 0,8 & 3,0 \\
\hline 30- V. A. R. F. & $-1,4$ & 1,2 & $-1,1$ & 1,1 & $-0,1$ & 1,0 & 0,9 \\
\hline & & CLAS & EE II, SÜBDIV & ÃO, TRATA & & & \\
\hline Nome paciente & PCM-ETE & GO-ETE & PPC-ETE & PDMI-ETE & PDMS-ETE & ACP-ETE & FCM-ETE \\
\hline 1-A. O. B. & 4,6 & $-5,9$ & $-1,5$ & 3,1 & $-3,4$ & 3,8 & -2 \\
\hline 2-A. E. & 3,4 & $-0,7$ & 3,1 & 5,6 & $-3,2$ & 0 & 5,1 \\
\hline 3-A. N. P. M. & $-1,6$ & 1,1 & 3,4 & 4,5 & $-0,8$ & $-1,9$ & 1,1 \\
\hline 4-A. B. S. & 0.5 & $-1,1$ & $-0,4$ & 1.7 & $-4,5$ & 0,3 & 2.3 \\
\hline 5-A. P. M. C. & $-2,3$ & 3,6 & 1,5 & 7,5 & 0,1 & $-6,7$ & 1,2 \\
\hline 6-A. P. S. R. & $-0,1$ & 1,3 & 0,8 & 2,9 & $-4,9$ & 5,6 & $-4,2$ \\
\hline 7-A. C. M. Jr. & $-6,5$ & 2,1 & 2,7 & 1,2 & $-2,9$ & $-9,4$ & 4,9 \\
\hline 8-B. S.R. M. & $-3,3$ & 6,7 & 2 & 8,7 & 1,6 & $-0,5$ & 5,6 \\
\hline 9-C. R. S. B. & $-1,8$ & $-0,3$ & $-2,1$ & 7,1 & $-2,5$ & $-1,5$ & 1,2 \\
\hline 10-C. J.S. & 1,2 & $-1,7$ & 0,9 & 7,9 & $-0,6$ & $-2,5$ & $-0,7$ \\
\hline 11-C. R. M. & $-0,6$ & $-0,8$ & $-1,1$ & 7,5 & $-0,4$ & 0,5 & $-3,1$ \\
\hline 12-D. C. M. G. & -2 & 3,4 & 5,7 & 7,4 & 0,5 & $-5,2$ & 2 \\
\hline 13-D. J. S. & $-3,6$ & 2,4 & 0,5 & 4,7 & $-1,9$ & $-8,1$ & 0,6 \\
\hline 14-D. C. & $-0,9$ & 5 & 4,9 & 8,3 & 2,5 & $-2,9$ & 0,7 \\
\hline 15-E. P. & $-3,5$ & 2,5 & 3,9 & 6,7 & 1,5 & $-1,7$ & 0,9 \\
\hline 16-E. F.S. & 2,2 & $-1,4$ & 1,5 & 3,6 & $-1,8$ & $-1,2$ & $-0,8$ \\
\hline 17-F. G. P. & 1,8 & -1 & $-0,4$ & $-1,9$ & $-5,3$ & 1,3 & $-0,6$ \\
\hline $18-F$. N. S. A. & $-1,5$ & $-0,9$ & 3,4 & $-0,1$ & $-7,5$ & $-3,5$ & 1,4 \\
\hline 19-J. F. A. N. & 1,9 & $-0,7$ & $-3,7$ & 3,3 & $-4,2$ & 4 & 3,4 \\
\hline 20-M. A. O. F. & 0 & 0,6 & 0,2 & 1,5 & $-5,6$ & 6,1 & 1,8 \\
\hline 21-M. M. S. & $-2,7$ & 0,8 & 2,2 & 0,2 & $-3,7$ & $-2,3$ & 1,7 \\
\hline 22-M. C. M. & $-1,7$ & 1,4 & 2,2 & 3,6 & $-1,1$ & $-3,2$ & 3,4 \\
\hline 23-M. C. C. & $-0,7$ & 0,2 & $-1,2$ & 0,1 & $-3,9$ & $-2,1$ & $-2,8$ \\
\hline 24-P. A. R. & $-0,7$ & 0,9 & 0,7 & 2,2 & $-3,1$ & $-3,7$ & 0,2 \\
\hline 25-R. G. & $-0,7$ & $-0,5$ & $-0,7$ & 0,8 & $-4,7$ & $-1,2$ & $-1,2$ \\
\hline 26-R. M. G. & 1 & $-0,2$ & 0,3 & 0 & $-6,4$ & 1,2 & $-0,8$ \\
\hline 27-R. M. P. & 0,4 & $-1,5$ & 1 & 3,7 & $-0,8$ & $-0,5$ & $-0,2$ \\
\hline 28-R. C. M. & 0,3 & 0 & $-0,4$ & 1,3 & $-3,9$ & $-1,7$ & $-2,1$ \\
\hline 29-S. A. P. & 1,1 & -1.3 & $-1,5$ & -1.5 & $-7,4$ & -3.5 & $-2,1$ \\
\hline 30-W. R. D. & $-2,8$ & 3 & 4,1 & 3,5 & $-1,9$ & $-4,1$ & 1,3 \\
\hline
\end{tabular}


Tabela A - 5

\begin{tabular}{|c|c|c|c|c|c|c|c|}
\hline Nome paciente & PCM-EIE & GO-EIE & $\begin{array}{l}\text { OCLUSÃO } \\
\text { PPC-EIE }\end{array}$ & $\begin{array}{l}\text { ORMAL } \\
\text { PDMI-EIE }\end{array}$ & PDMS-EIE & LMM-EIE & LMDI-EIE \\
\hline 1- A. C. J.P. & 0,3 & 5,1 & $-0,1$ & 2,9 & 1,9 & 1,0 & $\begin{array}{l}1,0 \\
1,0\end{array}$ \\
\hline 2-A. C. M. & 0,2 & 2,9 & $-2,0$ & $-2,2$ & $-0,8$ & $-2,4$ & $-2,4$ \\
\hline 3- A. E. A. & $-0,1$ & 1,8 & 3,4 & 1,2 & 2,2 & 2,1 & 2,0 \\
\hline 4- A. T. N. & 1,7 & 2,6 & 4,8 & 6,1 & 5,6 & 2,3 & 3,6 \\
\hline 5- A. C. R. & $-1,2$ & $-1,2$ & $-1,2$ & $-2,8$ & $-2,9$ & $-0,9$ & $-0,9$ \\
\hline 6- A. M. K. & 1,9 & 3,4 & 2,0 & 2,8 & 3,6 & 0,6 & 1,0 \\
\hline 7-C. A. C. & 0,6 & 0,2 & $-4,7$ & $-1,3$ & $-0,6$ & $-0,7$ & $-0,4$ \\
\hline 8- C. F. & 0,5 & $-0,1$ & $-0,1$ & $-0,5$ & $-0,2$ & $-0,7$ & $-0,5$ \\
\hline 9- C. J. C. & $-1,2$ & $-2,0$ & 1,6 & $-0,3$ & 1,1 & 0,5 & 0,4 \\
\hline 10-D.S.M. & 0,9 & 1,5 & $-4,9$ & $-4,5$ & $-3,5$ & $-3,4$ & $-3,6$ \\
\hline 11- D. A. A. & 1,0 & 0,1 & $-0,8$ & 3,0 & 2,8 & 3,4 & 1,5 \\
\hline 12- F. Y. & $-1,1$ & 1,1 & 1,5 & 3,1 & 2,6 & 0,9 & 2,3 \\
\hline 13- F. G. A. & 1,5 & $-0,2$ & $-3,0$ & $-5,3$ & $-3,9$ & $-3,1$ & $-2,9$ \\
\hline 14- F. P. A. Jr. & 1,2 & 2,2 & 1,2 & 1,9 & 0,9 & 0,0 & 0,5 \\
\hline 15-H.F.S. & $-0,6$ & $-1,1$ & 1,6 & $-0,4$ & $-0,3$ & 0,5 & 0,0 \\
\hline 16-J.R.P. & 0,3 & 2,0 & $-4,7$ & $-2,1$ & $-1,9$ & $-0,6$ & $-0,6$ \\
\hline 17-J.K. & $-2,3$ & $-1,3$ & $-7,6$ & $-8,3$ & $-7,6$ & $-4,5$ & $-5,3$ \\
\hline 18- J. L D. & 0,1 & $-2,5$ & $-2,2$ & $-3,0$ & $-2,3$ & $-0,5$ & $-0,4$ \\
\hline 19- L. M. C. & 1,7 & $-0,1$ & $-1,3$ & $-1,2$ & $-1,9$ & $-1,2$ & 0,2 \\
\hline 20-M.R. F. & $-0,3$ & $-4,6$ & $-3,4$ & $-8,3$ & $-6,6$ & $-5,8$ & $-5,4$ \\
\hline 21-M. C. R. M. & 1,5 & $-0,3$ & $-0,1$ & 0,8 & 0,4 & 0,2 & 0,3 \\
\hline 22- M. H. D. & $-2,0$ & $-1,8$ & $-1,1$ & $-1,6$ & $-1,7$ & $-1,7$ & $-0,8$ \\
\hline 23- M. F. & $-0,8$ & 1,9 & $-1,3$ & 1,3 & 1,3 & $-0,5$ & 1,0 \\
\hline 24- N. Z. V. & 0,0 & 2,5 & 5,7 & 7,5 & 7,3 & 4,1 & 3,8 \\
\hline 25-R. T. & 2,0 & $-2,4$ & $-6,3$ & $-8,8$ & $-7,8$ & $-8,0$ & $-5,7$ \\
\hline 26-R.P. & $-0,9$ & $-3,6$ & $-3,6$ & $-4,0$ & $-3,1$ & $-4,5$ & $-3,3$ \\
\hline 27-R. B. F. A. & 0,1 & 2,6 & 2,5 & 4,0 & 3,6 & 2,7 & 2,6 \\
\hline 28- S. H. & $-0,9$ & 1,1 & $-2,4$ & $-3,1$ & $-2,3$ & $-1,7$ & $-0,1$ \\
\hline 29- S. B. & 0,0 & 1,3 & $-3,7$ & $-2,7$ & $-3,1$ & $-2,6$ & $-2,5$ \\
\hline 30- V. A. R. F. & 1,7 & 0,1 & $-3,6$ & $-3,0$ & $-2,1$ & $-2,9$ & $-2,0$ \\
\hline & & CLASS & II, SUBDIV & ÃO, TRATA & & & \\
\hline $\begin{array}{l}\text { Nome paciente } \\
\text { 1-A. O. B. }\end{array}$ & $\begin{array}{c}\text { PCM-EIE } \\
-2\end{array}$ & $\begin{array}{c}\text { GO-EIE } \\
-1,4\end{array}$ & $\begin{array}{l}\text { PPC-EIE } \\
-0,8\end{array}$ & $\begin{array}{c}\text { PDMI-EIE } \\
-3,8\end{array}$ & PDMS-EIE & $\begin{array}{l}\text { LMM-EIE } \\
-3 ?\end{array}$ & $\begin{array}{l}\text { LMDI-EIE } \\
-4,5\end{array}$ \\
\hline 2-A. E. & $-1,3$ & 4 & $-1,5$ & 7 & 6,7 & 0,5 & -03 \\
\hline 3-A. N. P. M. & 0,9 & 3,5 & $-0,6$ & -1 & 1,2 & -2.6 & -26 \\
\hline 4-A. B. S. & 0,7 & 1,8 & 5.1 & 11,2 & 8.2 & 1,1 & 27 \\
\hline 5-A. P. M. C. & $-0,7$ & 1,9 & $-6,7$ & -4 & $\begin{array}{l}0,2 \\
-1,7\end{array}$ & $\begin{array}{l}1,1 \\
-1,9\end{array}$ & $\begin{array}{l}2,1 \\
-1,8\end{array}$ \\
\hline 6-A. P. S. R. & 1,1 & 2,7 & 1,2 & $-1,5$ & -1 & 0,5 & $-1,1$ \\
\hline 7-A. C. M. Jr. & -0.7 & 0.1 & $-4,3$ & $-3,6$ & $-1,1$ & -2 & -2 \\
\hline 8-B. S.R. M. & $-0,3$ & $-2,7$ & $-0,2$ & 1 & $-2,4$ & $-2,8$ & $-2,8$ \\
\hline 9-C. R. S. B. & 2,3 & 0,5 & 1,5 & $-4,5$ & $-3,8$ & $-1,8$ & $-1,4$ \\
\hline 10-C. J.S. & -0.9 & 3.6 & 2.5 & 2.7 & 1.6 & 2 & 1.9 \\
\hline 11-C. R.M. & $-0,7$ & -4 & $-1,5$ & $-7,7$ & $-3,8$ & -3 & $-1,3$ \\
\hline 12-D. C. M. G. & $-1,7$ & 0,9 & 0,1 & $-1,6$ & 1,8 & $-1,3$ & 1,1 \\
\hline 13-D. J. S. & 2,5 & 2,4 & 0,8 & -4 & $-1,5$ & $-1,5$ & 1,7 \\
\hline 14-D. C. & 0,7 & 0,6 & -2 & $-8,3$ & $-3,7$ & $-4,1$ & $-4,1$ \\
\hline 15-E. P. & 1,4 & $-0,1$ & $-1,6$ & $-5,4$ & $-3,6$ & $-2,9$ & $-2,6$ \\
\hline 16-E. F.S. & 1,1 & $-0,1$ & $-1,1$ & $-5,9$ & $-3,2$ & $-1,4$ & 1 \\
\hline 17-F. G. P. & $-1,8$ & $-5,5$ & $-2,9$ & $-0,8$ & 4,7 & 0,8 & 0,5 \\
\hline $18-F$. N. S. A. & 1,8 & 7,2 & 3,6 & 1,4 & 2,6 & $-0,3$ & $-0,2$ \\
\hline 19-J. F. A. N. & $-1,7$ & $-2,7$ & 0,7 & $-0,1$ & 4,2 & 4,5 & 5,2 \\
\hline 20-M. A. O. F. & 1,1 & 0,6 & $-0,5$ & $-0,2$ & 0,8 & 1,6 & $-1,2$ \\
\hline 21-M. M. S. & $-1,3$ & $-6,7$ & $-2,8$ & $-9,5$ & $-8,1$ & -5 & $-4,9$ \\
\hline 22-M. C. M. & 0 & $-4,4$ & 0,9 & -9 & $-7,2$ & $-7,3$ & $-2,9$ \\
\hline 23-M. C. C. & 2,2 & $-0,3$ & 4 & $-0,5$ & 4,4 & $-0,2$ & $-0,2$ \\
\hline 24-P. A. R. & 0,4 & $-1,6$ & $-0,1$ & $-5,5$ & $-3,8$ & $-3,6$ & $-3,6$ \\
\hline 25-R. G. & $-2,7$ & $-4,7$ & $-3,4$ & $-4,9$ & $-2,7$ & $-2,7$ & $-2,8$ \\
\hline 26-R. M. G. & 0,4 & $-6,8$ & $-4,6$ & -2 & 1,6 & $-0,7$ & $-0,9$ \\
\hline 27-R. M. P. & 3,7 & 2,7 & 5,5 & 1,9 & 5,8 & 2,3 & 5,1 \\
\hline 28-R. C. M. & $-0,4$ & $-0,1$ & 0,7 & 1,1 & 3,8 & $-0,2$ & 0,3 \\
\hline 29-S. A. P. & $-1,4$ & 0.2 & 2.6 & 2.3 & 3.2 & 1.3 & 1,4 \\
\hline 30-W. R. D. & 5,7 & 2 & 3,7 & $-4,1$ & 0,6 & $-3,6$ & $-3,7$ \\
\hline
\end{tabular}


Tabela A - 6

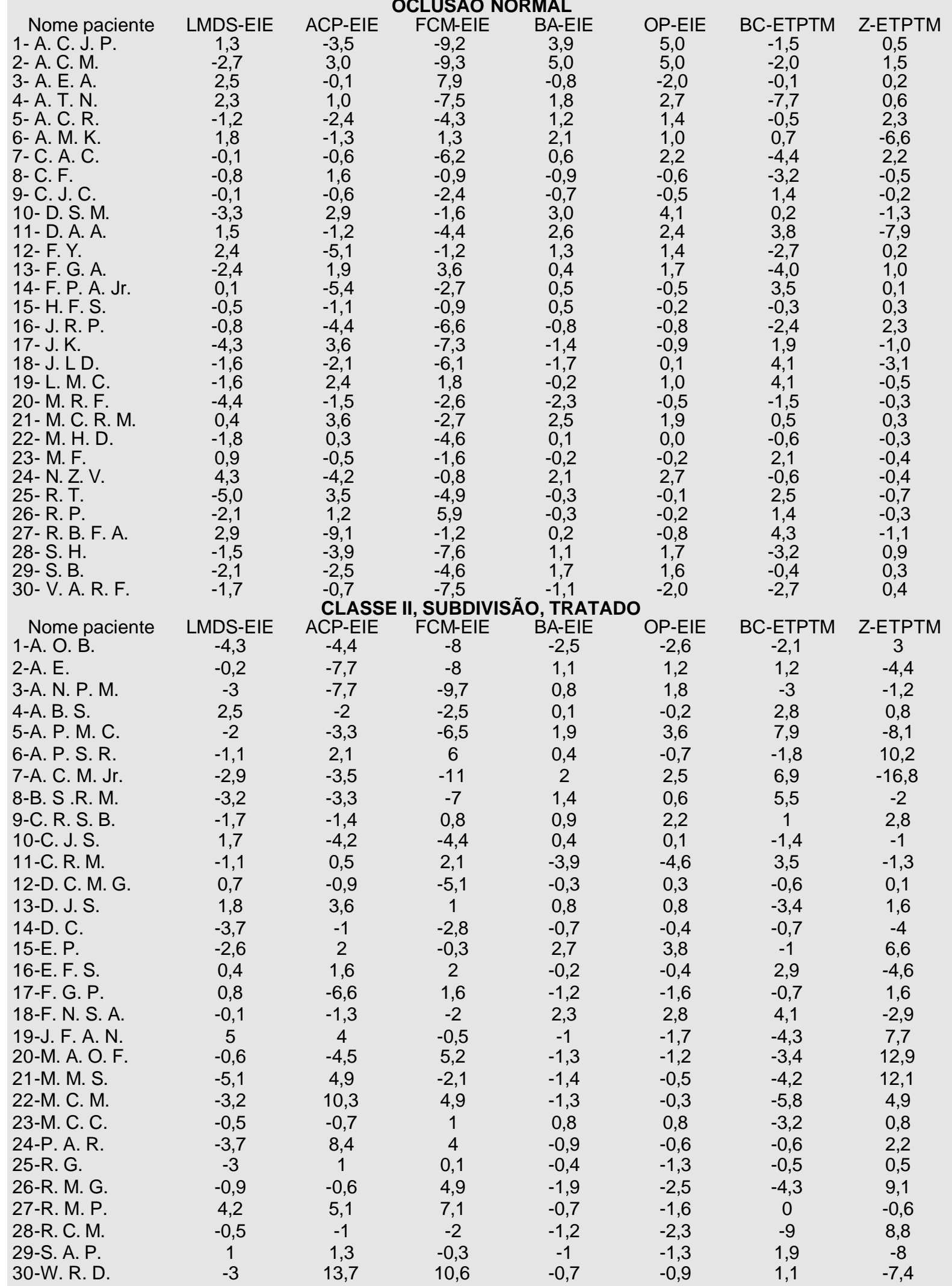


Tabela A - 7

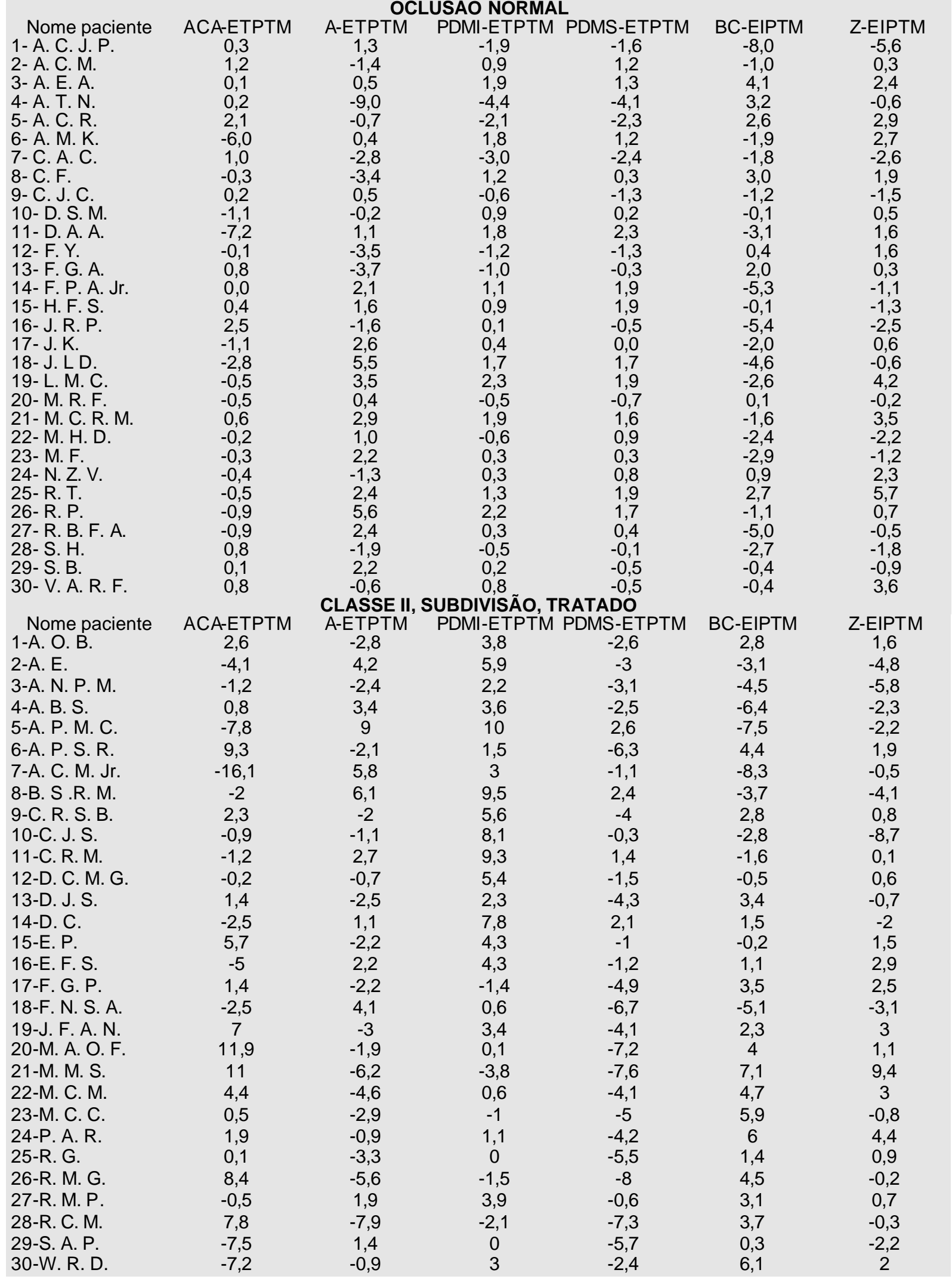


Tabela A - 8

\begin{tabular}{|c|c|c|c|c|c|c|}
\hline & & & & & & \\
\hline Nome paciente & ACA-EIPTM & A-EIPTM & VA-EIPTM & VP-EIPTM & PDMI-EIPTM & PDMS-EIPTM \\
\hline 1-A.C. J.P. & $-9,9$ & $-8,3$ & $-2,7$ & $-2,1$ & 0,8 & $-0,3$ \\
\hline 2- A. C. M. & $-2,3$ & $-3,3$ & $-0,6$ & $-0,3$ & 1,3 & 2,5 \\
\hline 3- A. E. A. & 7,0 & 3,1 & 1,2 & 0,5 & $-2,0$ & $-0,9$ \\
\hline 4- A. T. N. & $-3,9$ & 4,8 & 2,2 & 1,5 & 12,8 & 11,9 \\
\hline 5- A. C. R. & 1,3 & 2,1 & 0,3 & $-0,2$ & 3,0 & 2,7 \\
\hline 6- A. M. K. & $-4,7$ & $-1,0$ & 1,6 & 1,6 & 3,6 & 4,4 \\
\hline 7- C. A. C. & $-6,0$ & $-1,7$ & 1,2 & 0,2 & 3,5 & 3,8 \\
\hline 8-C. F. & 1,3 & 3,6 & $-0,3$ & $-0,1$ & 1,8 & 2,0 \\
\hline 9- C. J. C. & $-1,7$ & $-1,0$ & $-1,3$ & $-0,7$ & $-1,1$ & 0,3 \\
\hline 10- D. S. M. & $-1,2$ & 1,9 & 0,9 & 0,7 & 2,0 & 2,8 \\
\hline 11 - D. A. A. & $-3,7$ & 2,6 & $-1,5$ & $-1,1$ & 2,9 & 2,9 \\
\hline 12- F.Y. & $-5,6$ & 0,4 & 1,4 & 1,2 & 5,2 & 4,7 \\
\hline 13- F. G. A. & $-0,2$ & 1,9 & $-0,3$ & 0,0 & $-2,5$ & $-1,2$ \\
\hline 14- F. P. A. Jr. & $-4,1$ & $-3,8$ & $-2,2$ & $-1,3$ & 0,7 & $-0,2$ \\
\hline 15- H. F.S. & $-1,9$ & 0,1 & 0,1 & $-0,4$ & 1,3 & 1,2 \\
\hline 16- J.R.P. & $-6,2$ & $-4,5$ & $-0,9$ & $-0,1$ & $-1,5$ & $-1,3$ \\
\hline 17- J. K. & 1,3 & $-2,6$ & $-1,6$ & $-0,1$ & $-2,8$ & $-2,1$ \\
\hline 18- J. L D. & $-2,2$ & $-6,2$ & $-1,4$ & $-0,3$ & $-2,3$ & $-1,4$ \\
\hline 19- L. M. C. & 2,1 & $-2,8$ & $-2,1$ & $-0,6$ & $-1,7$ & $-2,2$ \\
\hline 20-M. R. F. & 2,3 & 0,8 & 1,0 & 0,0 & $-1,8$ & $-0,3$ \\
\hline 21- M. C. R. M. & 6,7 & $-0,9$ & 0,2 & 0,6 & $-0,2$ & $-0,5$ \\
\hline 22- M. H. D. & $-2,4$ & $-3,7$ & $-1,8$ & $-0,4$ & $-1,4$ & $-1,5$ \\
\hline 23- M. F. & $-3,0$ & $-3,3$ & $-1,5$ & 0,0 & 0,3 & 0,3 \\
\hline 24- N. Z. V. & $-2,3$ & 3,0 & 0,6 & 1,7 & 9,7 & 9,4 \\
\hline $25-$ R.T. & 7,7 & 2,9 & 0,3 & 1,1 & $-2,5$ & $-1,4$ \\
\hline 26- R.P. & 4,0 & $-3,8$ & 0,3 & 0,6 & $-3,5$ & $-2,6$ \\
\hline 27- R. B. F. A. & $-5,6$ & $-4,7$ & $-0,3$ & $-0,4$ & $-0,1$ & $-0,2$ \\
\hline 28- S. H. & $-9,4$ & $-5,0$ & -1.8 & $-1,0$ & $-0,7$ & 0,0 \\
\hline 29- S. B. & $-4,1$ & $-2,2$ & $-0,5$ & 0,2 & 1,8 & 1,2 \\
\hline 30- V. A. R. F. & $-1,3$ & 0,9 & $-0,3$ & 0,4 & 1,0 & 1,7 \\
\hline Nome paciente & ACA-EIPTM & $\begin{array}{l}\text { CLASSE II } \\
\text { A-EIPTM }\end{array}$ & $\begin{array}{l}\text { UBDIVISĀO, } \\
\text { VA-EIPTM }\end{array}$ & $\begin{array}{l}\text { TRATADO } \\
\text { VP-EIPTM }\end{array}$ & PDMI-EIPTM & \\
\hline 1-A. O. B. & A & 0,8 & 1,1 & $\begin{array}{c}1 \\
V P-C I T I\end{array}$ & $\begin{array}{c}-1 \\
-1\end{array}$ & $\begin{array}{l}2,7 \\
2,7\end{array}$ \\
\hline 2-A. E. & $-7,5$ & $-4,6$ & 1,5 & 0,4 & 8,4 & 8,1 \\
\hline 3-A. N. P. M. & $-10,9$ & $-4,8$ & 1,9 & 0,6 & 2,2 & 4,5 \\
\hline 4-A. B. S. & $-6,9$ & $-6,1$ & 0 & $-1,2$ & 3,4 & 0,2 \\
\hline 5-A. P. M. C. & $-3,6$ & $-9,2$ & -5 & 0,4 & $-1,7$ & 0,4 \\
\hline 6-A. P. S. R. & 5,8 & 3,6 & 2,2 & 2 & 1 & 1,5 \\
\hline 7-A. C. M. Jr. & $-1,7$ & $-6,4$ & $-1,3$ & $-0,1$ & $-0,2$ & 2,2 \\
\hline 8-B. S .R. M. & $-2,2$ & $-5,6$ & $-1,1$ & $-1,2$ & 3 & $-0,4$ \\
\hline 9-C. R. S. B. & 1,4 & 2,7 & 0,9 & 0,9 & $-1,1$ & $-0,3$ \\
\hline 10-C. J. S. & $-7,7$ & $-2,6$ & $-1,4$ & $-0,9$ & 1,6 & 0,5 \\
\hline 11-C. R. M. & 3,7 & $-1,4$ & 1,6 & 1,1 & $-9,4$ & $-5,7$ \\
\hline 12-D. C. M. G. & $-6,6$ & $-0,9$ & $-0,3$ & $-0,7$ & 1,1 & 4,7 \\
\hline 13-D. J. S. & 0,2 & 3,3 & 2,3 & 0 & $-2,7$ & $-0,1$ \\
\hline 14-D. C. & $-1,5$ & $-2,9$ & 0,3 & $-0,7$ & $-7,4$ & $-2,7$ \\
\hline 15-E. P. & $-1,9$ & 1,8 & $-0,2$ & 0 & $-0,1$ & 1,7 \\
\hline 16-E. F.S. & 2,2 & $-0,7$ & 1 & 1,4 & $-3,8$ & $-1,1$ \\
\hline 17-F. G. P. & 5,2 & 4,6 & 1,1 & 0,9 & $-2,3$ & 3,3 \\
\hline $18-F$. N. S. A. & $-7,3$ & $-4,5$ & 1,4 & 1,4 & 0,2 & 1,5 \\
\hline 19-J. F. A. N. & 8,9 & $-2,1$ & 1,6 & $-0,1$ & 0,1 & 4,3 \\
\hline 20-M. A. O. F. & 1.9 & 3.7 & 1.8 & 0,8 & 2.8 & 3.9 \\
\hline 21-M. M. S. & 14.5 & 9.8 & 4,4 & 3.1 & 1.5 & 3.1 \\
\hline 22-M. C. M. & 8,4 & 7,3 & 0,9 & 0 & $-4,6$ & $-2,8$ \\
\hline 23-M. C. C. & 3 & 5,9 & 2,5 & 0,4 & 1,8 & 6,8 \\
\hline 24-P. A. R. & 11,4 & 5 & 0,7 & 0,7 & -3 & $-1,3$ \\
\hline 25-R. G. & 4,7 & 3 & 1,2 & 1,3 & -2 & 0,2 \\
\hline 26-R. M. G. & 4,6 & 8,1 & 3 & 0,7 & $-2,1$ & 1,6 \\
\hline 27-R. M. P. & 4,5 & 1,6 & 1,3 & 0,1 & $-3,3$ & 0,6 \\
\hline 28-R. C. M. & $-2,1$ & 3,7 & 2,7 & 1,5 & 4,3 & 7,1 \\
\hline 29-S. A. P. & -3 & $-1,2$ & 0,6 & 0,4 & 0,6 & 1,3 \\
\hline 30-W. R. D. & 8,2 & 4,7 & 0,2 & $-0,6$ & $-7,8$ & $-3,1$ \\
\hline
\end{tabular}


Tabela A - 9

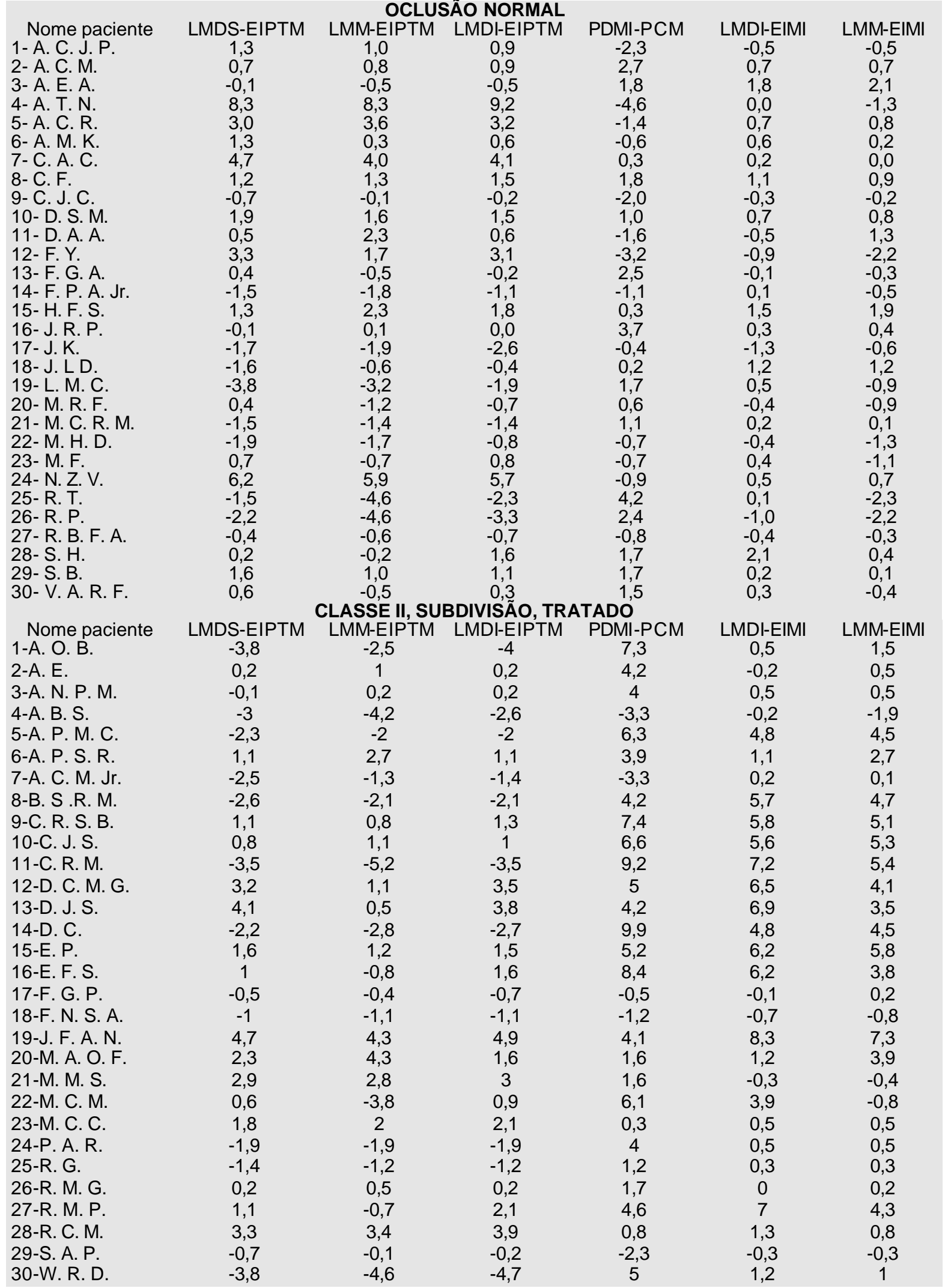


Tabela A - 10

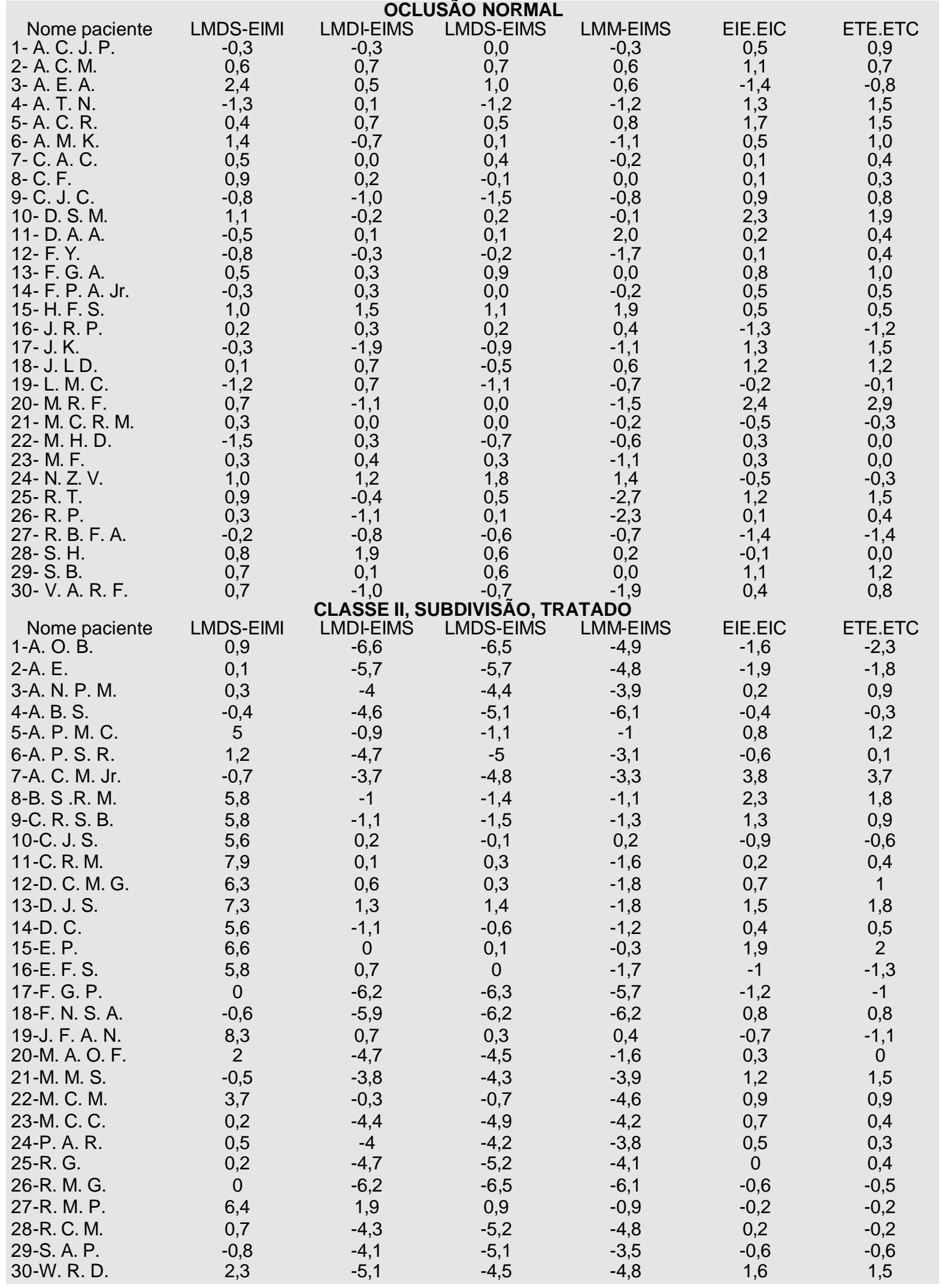


Tabela A - 11

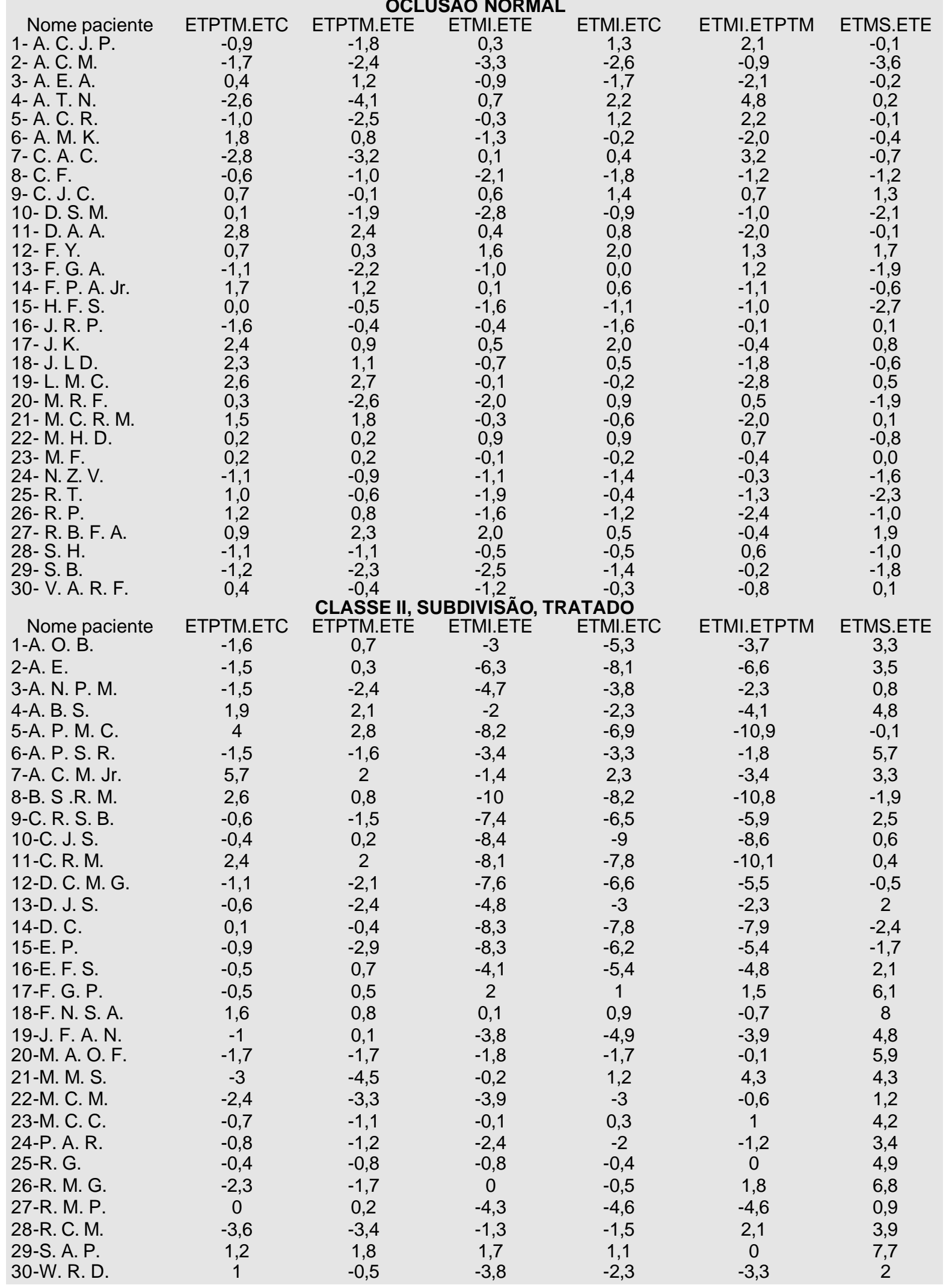


Tabela A - 12

\begin{tabular}{|c|c|c|c|c|c|c|c|}
\hline & & OCLI & ORM & & & & \\
\hline Nome paciente & ETMS.ETC & ETMS-ETPTM & PCM-LMM & РCM-CMM & POSM & POSMS & ÂPLANOZ \\
\hline 1- A. C. J.P. & 0,8 & 1,7 & $-1,3$ & 1,6 & 3,7 & 3,9 & 89,0 \\
\hline 2- A. C. M. & $-3,0$ & $-1,2$ & 1,3 & 0,6 & 0,2 & 1,0 & 92,2 \\
\hline 3-A. E. A. & $-1,0$ & $-1,4$ & $-0,3$ & 3,8 & $-2,4$ & $-2,7$ & 88,8 \\
\hline 4-A.T.N. & 1,7 & 4,4 & $-3,4$ & $-5,3$ & 3,7 & 4,4 & 91,6 \\
\hline 5- A. C. R. & 1,4 & 2,4 & $-1,7$ & $-2,0$ & $-0,4$ & $-0,2$ & 89,0 \\
\hline 6- A. M. K. & 0,6 & $-1,2$ & $-0,6$ & $-1,2$ & 0,1 & 0,8 & 91,6 \\
\hline 7-C. A. C. & $-0,3$ & 2,5 & 0,9 & 0,6 & $-0,1$ & $-1,4$ & 89,4 \\
\hline 8-C. F. & $-0,9$ & $-0,2$ & 0,4 & 3,5 & 1,8 & 1,3 & 90,1 \\
\hline 9- C.J.C. & 2,1 & 1,4 & $-2,1$ & $-1,9$ & $-2,4$ & $-2,2$ & 88,5 \\
\hline 10-D.S.M. & $-0,1$ & $-0,2$ & 0,2 & $-2,7$ & 0,0 & 0,5 & 91,6 \\
\hline 11- D. A. A. & 0,3 & $-2,4$ & $-3,0$ & 1,2 & 2,7 & 3,1 & 89,9 \\
\hline 12- F. Y. & 2,0 & 1,4 & $-1,0$ & $-1,5$ & $-0,7$ & 0,0 & 90,1 \\
\hline 13- F. G. A. & $-0,8$ & 0,3 & 2,9 & 3,1 & $-1,4$ & $-2,7$ & 89,2 \\
\hline 14- F.P. A. Jr. & 0,0 & $-1,8$ & 0,0 & 0,9 & 1,1 & 1,9 & 89,0 \\
\hline 15-H.F.S. & $-2,2$ & $-2,1$ & $-1,6$ & 4,3 & 1,3 & 1,1 & 88,2 \\
\hline 16-J.R.P. & $-1,1$ & 0,4 & 3,1 & 3,8 & 1,9 & 2,9 & 90,1 \\
\hline 17-J.K. & 2,4 & 0,0 & 1,2 & $-2,0$ & $-1,0$ & $-1,3$ & 90,3 \\
\hline 18-J.LD. & 0.6 & $-1,7$ & -0.8 & 2.6 & 1,5 & -0.1 & 90.8 \\
\hline 19- L. M. C. & 0,4 & $-2,2$ & 2,5 & 2,7 & $-1,0$ & $-2,0$ & 90,2 \\
\hline 20-M. R. F. & 1,0 & 0,7 & 2,4 & 4,6 & $-2,3$ & $-2,6$ & 92,0 \\
\hline 21 - M. C. R.M. & $-0,2$ & $-1,7$ & 1,2 & $-0,6$ & $-0,4$ & $-0,2$ & 88,0 \\
\hline 22- M. H. D. & $-0,8$ & $-0,9$ & 1,0 & $-0,8$ & $-1,9$ & $-1,5$ & 88,6 \\
\hline 23-M. F. & $-0,1$ & $-0,3$ & 0,2 & $-0,2$ & 2,3 & 1,9 & 89,9 \\
\hline 24- N. Z. V. & $-1,9$ & $-0,7$ & $-2,8$ & 0,3 & $-0,4$ & $-0,7$ & 87,8 \\
\hline 25-R.T. & $-0,8$ & $-1,8$ & 7,4 & 5,2 & $-2,6$ & $-3,0$ & 90,3 \\
\hline 26-R.P. & $-0,6$ & $-1,8$ & 4,4 & 3,3 & $-0,6$ & $-0,7$ & 90,7 \\
\hline 27-R. B. F. A. & 0,4 & $-0,4$ & $-0,1$ & $-1,0$ & 0,2 & 0,5 & 89,9 \\
\hline 28- S. H. & $-1,0$ & 0,1 & 1,7 & 1,1 & 1,3 & 1,1 & 88,5 \\
\hline 29- S. B. & $-0,6$ & 0,5 & 1,5 & 3,4 & 3,0 & 2,5 & 92,3 \\
\hline 30- V. A. R. F. & 0,9 & 0,5 & 2,2 & 1,8 & $-1,6$ & $-2,7$ & 89,6 \\
\hline & & CLASSE II, S & JBDIVISÃO, & TRATADO & & & \\
\hline Nome paciente & ETMS.ETC & ETMS.ETPTM & PCM-LMM & PCM-CMM & POSM & POSMS & ÂPLANOZ \\
\hline 1-A. O. B. & 0,9 & 2,6 & 5,5 & 5,8 & $-2,3$ & $-0,7$ & 91,1 \\
\hline 2-A. E. & 1,7 & 3,2 & 1,6 & 3,1 & $-1,9$ & 3,3 & 89,9 \\
\hline 3-A. N. P. M. & 1,8 & 3,2 & 3 & 3,5 & 0,8 & 1,5 & 90,1 \\
\hline 4-A. B. S. & 4,5 & 2.6 & -0.1 & 2.3 & -3.6 & 1.3 & 88 \\
\hline 5-A. P. M. C. & 1,1 & $-2,9$ & 0 & $-0,3$ & $-1,3$ & 0,9 & 88,9 \\
\hline 6-A. P. S. R. & 5,8 & 7,3 & 0,6 & 2,4 & $-1,2$ & 2 & 88,4 \\
\hline 7-A. C. M. Jr. & 7 & 1.3 & $-3,6$ & 0.8 & 1.5 & $-0,6$ & 89.8 \\
\hline 8-B. S.R. M. & $-0,1$ & -2.7 & 0.2 & -1 & -1.9 & -0.4 & 88,5 \\
\hline $9-C . R$ S. B & 34 & 4 & 1 & 0.2 & -1 & 29 & 91.8 \\
\hline 10-C. J.S. & $-0,1$ & 0,3 & $-1,2$ & -0.9 & $-1,4$ & 2.7 & 92,5 \\
\hline 11-C. R.M. & 0,8 & $-1,6$ & 2,2 & 2,7 & $-4,5$ & -2 & 91,1 \\
\hline 12-D. C. M. G. & 0,5 & 1,6 & $-0,9$ & $-2,7$ & 0,5 & 2,1 & 90,7 \\
\hline 13-D. J. S. & 3,8 & 4,4 & 0,4 & 1,2 & $-0,7$ & 1,2 & 89,4 \\
\hline 14-D. C. & $-1,9$ & -2 & 2,9 & $-0,9$ & $-0,7$ & 1,7 & 91 \\
\hline 15-E. P. & 0,4 & 1,2 & $-0,5$ & $-4,1$ & $-1,5$ & 1 & 89,9 \\
\hline 16-E. F.S. & 0,9 & 1,4 & 3,9 & 2,4 & $-1,9$ & 1,4 & 89,9 \\
\hline 17-F. G. P. & 5,2 & 5,6 & $-0,1$ & 1,3 & 0 & 0,3 & 88,8 \\
\hline $18-F$. N. S. A. & 8,8 & 7,2 & $-0,1$ & $-2,4$ & 5,5 & 7,4 & 90,1 \\
\hline 19-J. F. A. N. & 3,8 & 4,7 & $-3,5$ & $-0,7$ & $-0,8$ & 3,2 & 89,1 \\
\hline 20-M. A. O. F. & 5,9 & 7,6 & $-1,7$ & $-1,6$ & 2,5 & 6,7 & 92 \\
\hline 21-M. M. S. & 5,7 & 8,8 & 2,4 & 4,6 & $-0,3$ & 1,3 & 89,9 \\
\hline 22-M. C. M. & 2,1 & 4,4 & 7 & 4,4 & $-2,8$ & $-0,9$ & 89 \\
\hline 23-M. C. C. & 4,6 & 5,3 & 0 & 2,2 & $-0,8$ & $-0,5$ & 91,7 \\
\hline 24-P. A. R. & 3,7 & 4,5 & 3,3 & 1,9 & $-1,5$ & 1 & 90,6 \\
\hline 25-R. G. & 5,3 & 5,7 & 1,4 & 1,3 & $-0,9$ & 1,2 & 91 \\
\hline 26-R. M. G. & 6,3 & 8,6 & 1,1 & 3,5 & $-2,7$ & -2 & 90,2 \\
\hline 27-R. M. P. & 0,7 & 0,7 & 0,1 & 2,4 & $-3,2$ & $-1,7$ & 86,4 \\
\hline 28-R. C. M. & 3,7 & 7,3 & 0,1 & 0,4 & 0,6 & 2,5 & 89,5 \\
\hline 29-S. A. P. & 7.1 & 5.9 & -1.7 & $-2,4$ & -1 & 0,1 & 91.6 \\
\hline 30-W. R. D. & 3,5 & 2,6 & 4,2 & 5,1 & $-1,2$ & $-0,4$ & 90,5 \\
\hline
\end{tabular}


Tabela A - 13

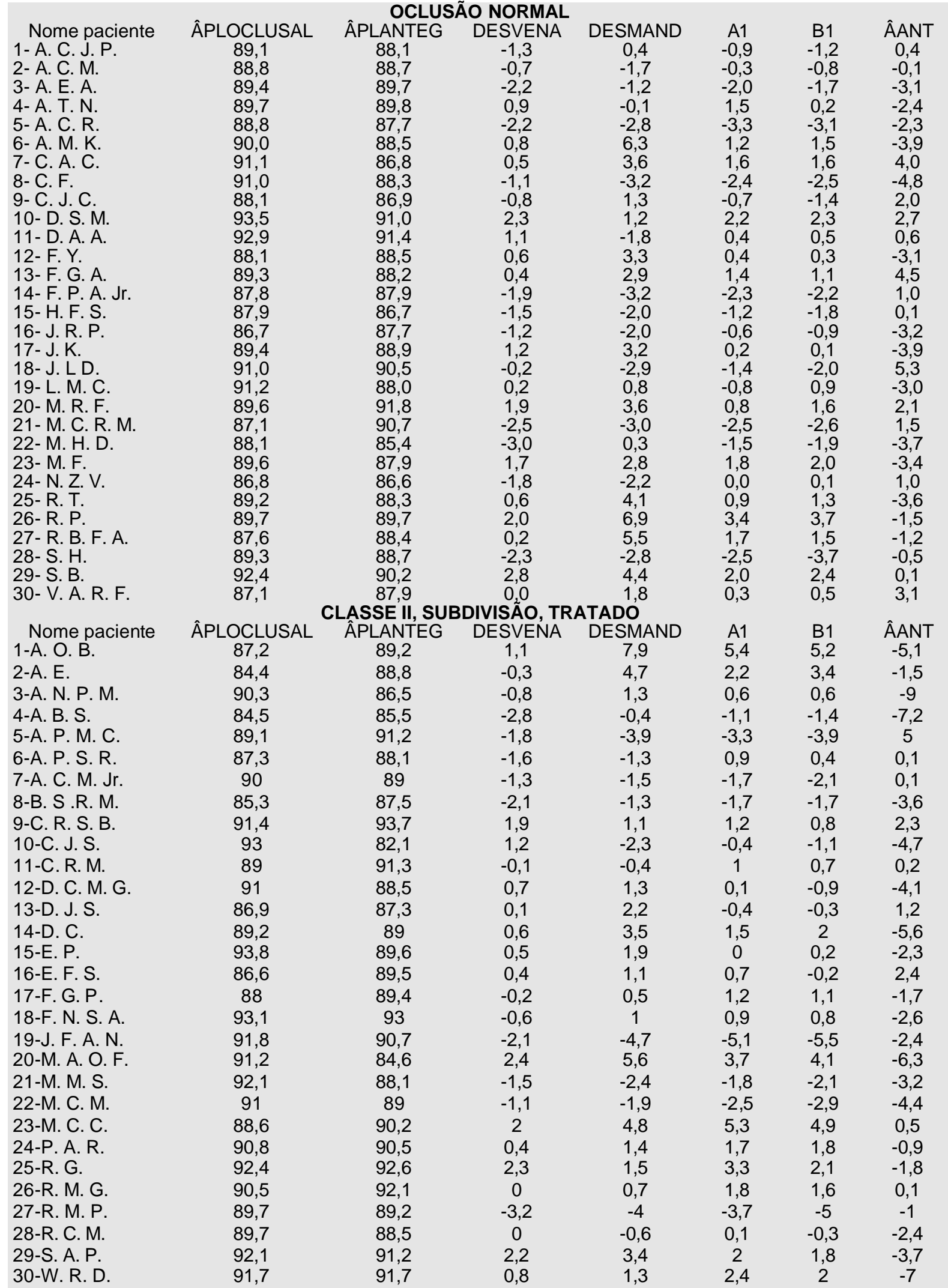


Tabela A - 14

\begin{tabular}{|c|c|c|c|c|c|c|}
\hline & & & ÃO NORM & & & \\
\hline Nome paciente & DISTZ & DISTCO & DISTZA & DISTNC & DISTJ & DISTAG \\
\hline 1- A. C. J.P. & 0,9 & 2,2 & 2,0 & 0,4 & 1,9 & $-0,4$ \\
\hline 2- A. C. M. & $-0,4$ & 2,4 & 2,1 & 1,7 & 1,9 & 2,3 \\
\hline 3-A. E. A. & 1,9 & $-3,4$ & $-1,4$ & 3,6 & 2,2 & 2,8 \\
\hline 4- A. T. N. & $-1,6$ & $-7,1$ & $-6,8$ & $-3,6$ & $-3,0$ & $-2,6$ \\
\hline 5-A. C. R. & 3,7 & 5,0 & 4,2 & 3,9 & 4,3 & 6,6 \\
\hline 6- A. M. K. & $-1,4$ & 6,1 & 3,4 & 1,6 & 1,2 & $-1,2$ \\
\hline 7-C. A. C. & $-2,7$ & $-2,1$ & $-1,5$ & $-3,0$ & $-3,2$ & $-11,6$ \\
\hline 8- C. F. & 1,7 & 0,5 & 0,5 & 2,6 & 3,1 & 5,5 \\
\hline 9- C. J. C. & $-0,5$ & $-2,5$ & $-2,7$ & $-0,6$ & $-0,4$ & $-5,7$ \\
\hline $10-$ D. S. M. & -2.9 & 0,3 & $-1,4$ & $-3,0$ & $-3,1$ & $-3,7$ \\
\hline 11- D. A. A. & $-3,0$ & $-0,3$ & $-0,7$ & 0,5 & $-0,2$ & 1,2 \\
\hline 12- F.Y. & 0,7 & $-3,9$ & $-2,1$ & 1,1 & $-0,2$ & $-5,1$ \\
\hline 13- F. G. A. & 0,3 & 7,7 & $-0,1$ & 0,8 & $-1,9$ & $-3,6$ \\
\hline 14- F. P. A. Jr. & 2,9 & 5,4 & 4,9 & 3,6 & 4,3 & 4,2 \\
\hline 15-H.F.S. & 3,1 & 1,5 & 2,2 & 3,6 & 2,8 & 0,5 \\
\hline 16-J.R.P. & $-0,8$ & 7,4 & 6,8 & 4,1 & 3,2 & 7,0 \\
\hline 17-J.K. & $-0,8$ & 2,3 & 7,1 & 2,2 & 1,9 & $-0,6$ \\
\hline 18- J. LD. & $-3,5$ & $-0,8$ & $-2,8$ & $-0,1$ & 0.1 & $-1,2$ \\
\hline 19- L. M. C. & 1,0 & 1,6 & 0,3 & 1,2 & 1,7 & 0,3 \\
\hline 20-M.R. F. & $-5,1$ & $-3,5$ & $-3,7$ & $-2,7$ & $-2,8$ & $-6,5$ \\
\hline 21- M. C. R. M. & 1,5 & 1,5 & 4,0 & 4,6 & 5,1 & 5,4 \\
\hline 22- M. H. D. & 1,7 & $-2,7$ & $-0,5$ & 3,1 & 1,2 & $-1,6$ \\
\hline 23- M. F. & 0,3 & $-2,4$ & 1,4 & $-1,2$ & $-2,1$ & $-4,6$ \\
\hline 24- N. Z. V. & 0,4 & 1,1 & 2,5 & 5,2 & 2,3 & 0,1 \\
\hline 25-R. T. & 2,0 & $-0,3$ & 2,3 & $0, \overline{6}$ & $-0,6$ & $-3,8$ \\
\hline 26- R.P. & $-3,4$ & $-9,3$ & $-5,0$ & $-3,7$ & $-6,0$ & $-12,4$ \\
\hline 27-R. B. F. A. & 0,0 & $-5,1$ & $-5,5$ & $-1,9$ & $-2,7$ & $-8,5$ \\
\hline 28- S. H. & 1,7 & 3,5 & 2,9 & 5,1 & 5,9 & 5,4 \\
\hline 29- S. B. & $-2,1$ & $-2,8$ & $-3,6$ & $-5,3$ & $-4,8$ & -7.6 \\
\hline 30- V. A. R. F. & 1,1 & 1.4 & 1,4 & 0,9 & 0,2 & $-5,5$ \\
\hline & & CLASSE II, & DIVISÃO, & TADO & & \\
\hline Nome paciente & DISTZ & DISTCO & DISTZA & DISTNC & DISTJ & DISTAG \\
\hline 1-A. O. B. & $-0,2$ & 3,9 & 0,4 & 0 & $-0,3$ & $-2,4$ \\
\hline 2-A. E. & 0,1 & 3,2 & 2,5 & 2,2 & 1 & $-2,5$ \\
\hline 3-A. N. P. M. & $-2,4$ & 3,7 & 2,5 & 4,3 & 3,5 & 4,5 \\
\hline 4-A. B. S. & 2,3 & 4,2 & 7,6 & 6,3 & 8 & 5,7 \\
\hline 5-A. P. M. C. & 0,5 & 8,3 & 7,5 & 4,5 & 4,5 & 6,5 \\
\hline 6-A. P. S. R. & $-0,3$ & $-0,1$ & 2,5 & 1,4 & 3 & 0,5 \\
\hline 7-A. C. M. Jr. & 2,4 & $-1,1$ & 2,8 & 2,7 & 2,9 & 0,7 \\
\hline 8-B. S.R. M. & 4,8 & 8,8 & 10,3 & 5,5 & 6 & 7,9 \\
\hline 9-C. R. S. B. & 0,3 & 0,7 & 0,4 & $-0,8$ & $-1,4$ & $-0,1$ \\
\hline 10-C. J. S. & $-1,3$ & $-0,8$ & 0,7 & $-1,7$ & $-0,5$ & -4 \\
\hline 11-C. R. M. & $-5,3$ & 7 & 3,9 & 2,2 & 1,2 & 4,9 \\
\hline 12-D. C. M. G. & $-0,2$ & $-0,9$ & 0,7 & 2 & 2,2 & $-0,8$ \\
\hline 13-D. J. S. & $-3,1$ & 1,8 & $-1,1$ & 1 & $-3,1$ & $-4,6$ \\
\hline 14-D. C. & 1,6 & 4,4 & 1,2 & 4,3 & 1,6 & 2,1 \\
\hline 15-E. P. & $-0,5$ & 5,9 & 0,1 & $-0,1$ & 2,7 & 2,5 \\
\hline 16-E. F.S. & 0,3 & $-0,8$ & $-0,8$ & -1 & $-0,8$ & $-3,7$ \\
\hline 17-F. G. P. & 3,9 & $-0,6$ & $-2,2$ & 2,8 & 4,8 & 0,7 \\
\hline 18-F. N. S. A. & $-3,6$ & $-7,1$ & $-6,2$ & $-3,3$ & $-3,9$ & 0,2 \\
\hline 19-J. F. A. N. & $-0,5$ & 1,4 & 2,5 & 1,7 & 2,9 & 9,1 \\
\hline 20-M. A. O. F. & $-1,8$ & $-0,8$ & $-5,4$ & $-3,8$ & $-3,6$ & $-9,1$ \\
\hline 21-M. M. S. & 1,7 & $-3,3$ & $-1,3$ & 0,6 & 1 & 1,2 \\
\hline 22-M. C. M. & 1 & 1 & 4,2 & 1,7 & 3,7 & 5,4 \\
\hline 23-M. C. C. & $-4,3$ & $-5,6$ & $-9,5$ & $-7,2$ & $-6,2$ & $-9,9$ \\
\hline 24-P. A. R. & 1,3 & 0,9 & 1,5 & $-1,4$ & $-0,4$ & 0,6 \\
\hline 25-R. G. & $-4,3$ & $-8,7$ & $-3,1$ & $-1,1$ & $-2,2$ & $-4,2$ \\
\hline 26-R. M. G. & $-2,7$ & 0,3 & 0,5 & 0,4 & 0,7 & 1,6 \\
\hline 27-R. M. P. & 4,2 & 1.1 & 3.3 & 3,3 & 4,4 & 7 \\
\hline 28-R. C. M. & 1,9 & 1,7 & 1,1 & 4 & 3,8 & 1,7 \\
\hline 29-S. A. P & -3.4 & -4.3 & -28 & -3.7 & -14 & $-3,2$ \\
\hline $30-W . R . D$. & $-1,1$ & -5.8 & -0.8 & $-1,4$ & 0.1 & 1.6 \\
\hline
\end{tabular}


Tabela A - 15

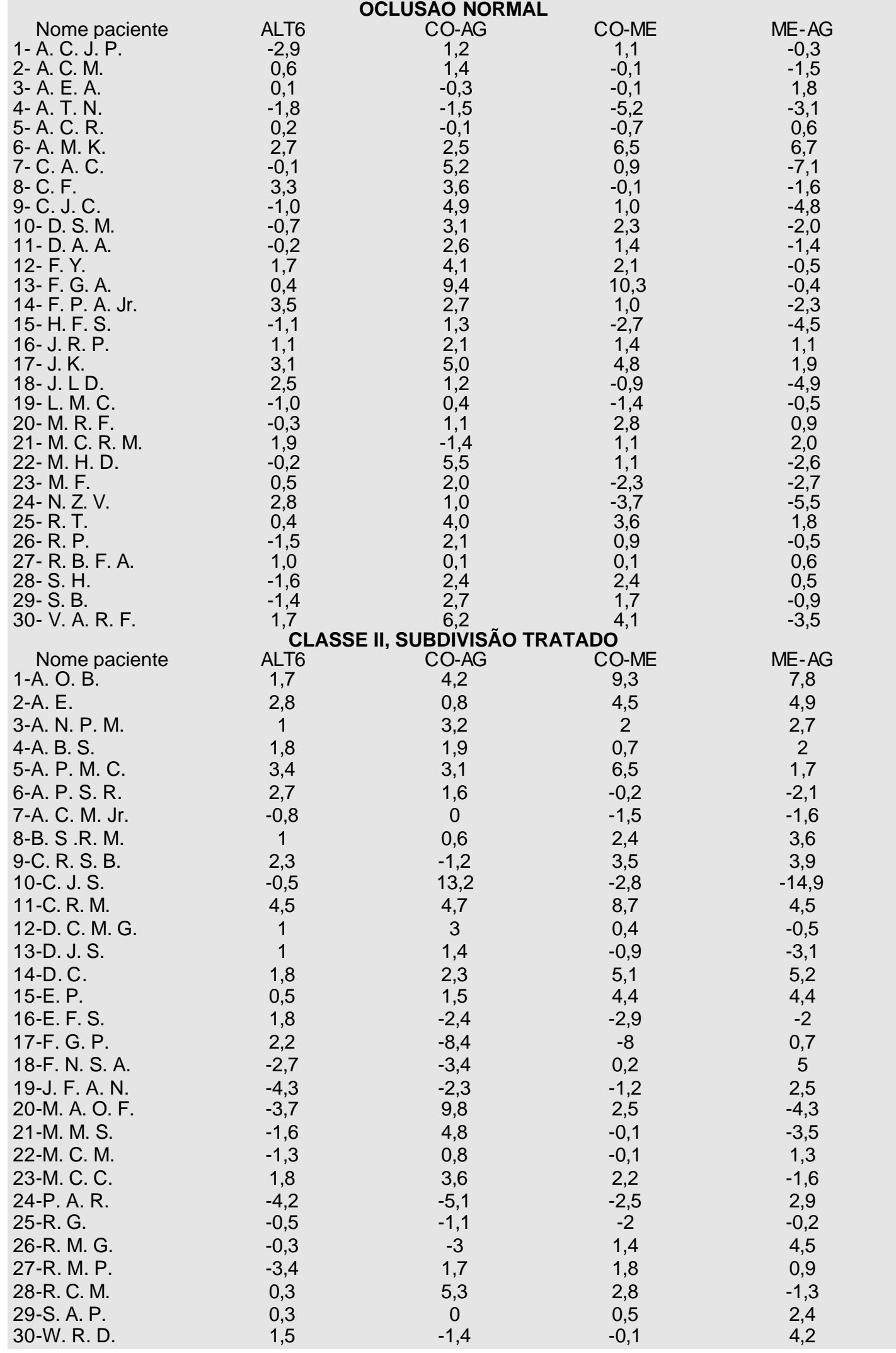


As tabelas de A - 16 a A - 19 consistem nos valores reais obtidos no $2^{\circ}$ traçado, dos 10 pacientes selecionados aleatoriamente, para a avaliação dos erros casuais e sistemáticos

Tabela A - 16 - Resultados do $2^{\circ}$ traçado para o erro intra-examinador

\begin{tabular}{|c|c|c|c|c|c|c|}
\hline & & LASSE II, & 3DIVISÃO, & ATADO & & \\
\hline Nome paciente & Sexo & Idade & GO-ETC & PPC-ETC & PDMI-ETC & PDMS-ETC \\
\hline 1-A.P. M. C. & $\mathrm{F}$ & 17,61 & $-0,5$ & $-0,2$ & 1,7 & $-4,5$ \\
\hline 2-A. P. S. R. & $\mathrm{F}$ & 14,13 & 2,2 & $-0,8$ & 6,2 & $-0,7$ \\
\hline 3-D. C. M. G. & $M$ & 15,93 & 0,2 & 1,9 & 5,8 & $-1,5$ \\
\hline 4-D. J. S. & $\mathrm{M}$ & 19,04 & 0,1 & $-2,4$ & 3,2 & $-4,7$ \\
\hline 5-E. P. & $\mathrm{F}$ & 18,08 & 0,3 & 1,9 & 6,5 & $-1,2$ \\
\hline 6-E. F.S. & $\mathrm{F}$ & 15,4 & $-1,8$ & $-0,6$ & 5,1 & $-0,6$ \\
\hline 7-J. A. N. & $M$ & 15,67 & 1,8 & $-0,7$ & 4,6 & $-2,9$ \\
\hline 8-M. A. O. & $M$ & 17,34 & 2 & $-0,2$ & 1 & $-5,9$ \\
\hline 9-M. M. S. & $\mathrm{F}$ & 16,5 & $-0,5$ & $-0,4$ & $-1,2$ & $-5,7$ \\
\hline 10-M. C. C. & $\mathrm{F}$ & 17,11 & $-0,6$ & $-2,6$ & 1 & $-5,5$ \\
\hline Nome paciente & GO-EIC & PPC-EIC & PDMI-EIC & PDMS-EIC & LMM-EIC & LMDI-EIC \\
\hline 1-A. P. M. C. & $-0,2$ & 3,7 & 5,9 & 7,5 & 1,6 & 1,9 \\
\hline 2-A. P. S. R. & 3,7 & $-3,7$ & $-2,5$ & $-0,2$ & $-0,8$ & 0,3 \\
\hline 3-D. C. M. G. & 1,9 & 4,4 & 4,6 & 8,8 & 2,6 & 5,1 \\
\hline 4-D. J. S. & 2 & 3,7 & $-2,4$ & 0,7 & 2,3 & 4 \\
\hline 5-E. P. & 0,3 & 0,3 & $-2,2$ & 0 & 0,7 & 0,7 \\
\hline 6-E. F. S. & 1,3 & 1 & -3 & $-2,7$ & 0,3 & 1,3 \\
\hline 7-J. A. N. & $-0,8$ & 3,4 & 1,5 & 4,7 & 5,2 & 5,1 \\
\hline 8-M. A. O. & 1,3 & 1,8 & 2,2 & 2,6 & 1,8 & 0,3 \\
\hline 9-M. M. S. & $-6,3$ & 1,1 & $-6,1$ & -5 & $-3,1$ & $-2,7$ \\
\hline 10-M. C. C. & 1,8 & 7,2 & 3,1 & 5,3 & 2 & 1,8 \\
\hline Nome paciente & LMDS-EIC & PCM-ETE & GO-ETE & PPC-ETE & PDMI-ETE & PDMS-ETE \\
\hline 1-A. P. M. C. & 1,1 & 0,9 & $-1,4$ & -1 & 1,3 & $-4,9$ \\
\hline 2-A. P. S. R. & 0,2 & $-1,9$ & 3,7 & 0,9 & 7,1 & 0,2 \\
\hline 3-D. C. M. G. & 4,4 & $-3,9$ & 4 & 5,4 & 7,7 & 0,5 \\
\hline 4-D. J. S. & 4 & $-1,8$ & 1,8 & $-0,8$ & 4 & $-3,8$ \\
\hline 5-E. P. & 0,7 & $-2,7$ & 3 & 4,3 & 7,8 & 0,2 \\
\hline 6-E. F. S. & 0,4 & -1 & $-0,9$ & 0,4 & 5,6 & $-0,1$ \\
\hline 7-J. A. N. & 5 & 1 & 0,7 & $-1,7$ & 4,1 & $-3,4$ \\
\hline 8-M. A. O. & 1 & 0,2 & 1,8 & $-0,4$ & 0,9 & -6 \\
\hline 9-M. M. S. & $-3,1$ & $-2,8$ & 2,3 & 2 & 0,1 & $-4,4$ \\
\hline 10-M. C. C. & 1,7 & $-2,3$ & 1,6 & $-0,6$ & 2,2 & $-4,3$ \\
\hline Nome paciente & ACP-ETE & FCM-ETE & PCM-EIE & GO-EIE & PPC-EIE & PDMI-EIE \\
\hline 1-A. P. M. C. & $-2,1$ & 0,7 & 1,6 & 1,4 & 5,9 & 8,3 \\
\hline 2-A. P. S. R. & $-6,4$ & 1,4 & $-1,3$ & 1,9 & $-6,3$ & $-5,3$ \\
\hline 3-D. C. M. G. & $-5,2$ & 1,9 & $-1,4$ & $-0,6$ & $-0,6$ & $-1,7$ \\
\hline 4-D. J. S. & $-7,9$ & 0,2 & 1,7 & 2,8 & 3,3 & $-3,3$ \\
\hline 5-E. P. & $-2,5$ & 0 & $-0,9$ & -1 & $-3,5$ & $-7,3$ \\
\hline 6-E. F. S. & -3 & $-1,7$ & $-1,1$ & 0,8 & 0,7 & $-3,1$ \\
\hline 7-J. A. N. & 1,8 & 3,7 & $-1,5$ & $-1,7$ & 2,5 & 0,6 \\
\hline 8-M. A. O. & 7,8 & $-1,5$ & $-1,4$ & $-0,5$ & $-0,8$ & $-0,7$ \\
\hline 9-M. M. S. & $-3,9$ & 1,8 & $-2,6$ & $-7,4$ & $-2,6$ & $-11,2$ \\
\hline 10-M. C. C. & $-3,2$ & $-1,7$ & 0,4 & 0,2 & 4,2 & $-0,5$ \\
\hline
\end{tabular}


Tabela A - 17 - Resultados do $2^{\circ}$ traçado para o erro intra-examinador

\begin{tabular}{|c|c|c|c|c|c|c|}
\hline & & CLASSE II, SL & JBDIVISÃO, T & RATADO & & \\
\hline Nome paciente & PDMS-EIE & LMM-EIE & LMDI-EIE & LMDS-EIE & ACP-EIE & FCM-EIE \\
\hline 1-A. P. M. C. & 9,9 & 3,1 & 3,3 & 2,6 & -2 & 0,4 \\
\hline 2-A. P. S. R. & -3 & $-2,6$ & $-1,5$ & $-1,6$ & $-2,4$ & -10 \\
\hline 3-D. C. M. G. & 2,5 & $-1,8$ & 0,7 & $-0,1$ & $-0,9$ & $-2,6$ \\
\hline 4-D. J. S. & $-0,2$ & 1,3 & 3 & 3 & 3,5 & $-0,2$ \\
\hline 5-E. P. & $-5,2$ & $-3,1$ & $-3,1$ & $-3,2$ & 1,1 & $-5,5$ \\
\hline 6-E. F. S. & $-2,8$ & 0,3 & 1,3 & 0,5 & $-0,3$ & 4,5 \\
\hline 7-J. A. N. & 3,8 & 4,8 & 4,7 & 4,6 & 5,4 & 4,2 \\
\hline 8-M. A. O. & $-0,3$ & $-0,1$ & $-1,5$ & $-0,9$ & $-3,6$ & $-5,2$ \\
\hline 9-M. M. S. & $-10,1$ & -7 & $-6,6$ & $-7,1$ & 6,5 & -2 \\
\hline 10-M. C. C. & 1,7 & $-0,5$ & $-0,7$ & -1 & $-0,5$ & 4,9 \\
\hline Nome paciente & Ba-EIE & Op-EIE & BC-ETPTM & Z-ETPTM & ACA-ETPTM & A-ETPTM \\
\hline 1-A. P. M. C. & 1,5 & 0,2 & 1,5 & $-3,7$ & $-3,3$ & 1,7 \\
\hline 2-A. P. S. R. & 1,7 & 3,2 & 4,8 & $-9,9$ & $-9,3$ & 5,9 \\
\hline 3-D. C. M. G. & $-0,6$ & 1,2 & 1,8 & $-5,3$ & $-4,8$ & 1,1 \\
\hline 4-D. J. S. & 0,8 & 1,4 & $-1,9$ & $-1,8$ & $-1,8$ & $-0,8$ \\
\hline 5-E. P. & 0,8 & 0,6 & 0,8 & 0,1 & $-0,2$ & $-1,1$ \\
\hline $\begin{array}{l}\text { 6-E. F. S. } \\
7 \text {-J. A. N. }\end{array}$ & $\begin{array}{l}-1,6 \\
-0,3\end{array}$ & $\begin{array}{l}-0,9 \\
-1,9\end{array}$ & $\begin{array}{l}1,3 \\
1,1\end{array}$ & $\begin{array}{c}-2 \\
-4,7\end{array}$ & $\begin{array}{c}-1 \\
-4,2\end{array}$ & $\begin{array}{l}0,6 \\
3,7\end{array}$ \\
\hline 8-M. A. O. & -2 & $-1,7$ & $-0,4$ & 8,3 & 7,6 & 0,2 \\
\hline 9-M. M. S. & $-1,3$ & $-0,9$ & 1,2 & $-0,3$ & $-0,2$ & $-0,6$ \\
\hline 10-M. C. C. & 0,5 & 0,5 & $-2,1$ & 0,1 & $-0,3$ & $-1,7$ \\
\hline Nome paciente & PDMI-ETPTM & PDMS-ETPTM & BC-EIPTM & Z-EIPTM & ACA-EIPTM & A-EIPTM \\
\hline 1-A. P. M. C. & 2,9 & $-3,3$ & $-3,5$ & -3 & $-7,4$ & $-3,4$ \\
\hline 2-A. P. S. R. & 8,5 & 1,5 & $-3,9$ & 0,5 & $-5,5$ & $-6,3$ \\
\hline 3-D. C. M. G. & 7,4 & 0,2 & $-2,4$ & 0 & $-6,8$ & $-2,2$ \\
\hline 4-D. J. S. & 2,9 & $-4,9$ & 1,7 & $-2,9$ & -2 & 0,1 \\
\hline 5-E. P. & 6,8 & $-0,9$ & $-1,4$ & 0,5 & $-2,7$ & $-1,4$ \\
\hline 6-E. F.S. & 5,5 & $-0,1$ & $-0,3$ & 0,6 & 1,9 & $-0,4$ \\
\hline 7-J. A. N. & 6,1 & $-1,4$ & 1 & 1,5 & 4,9 & $-5,4$ \\
\hline 8-M. A. O. & 0,9 & -6 & 1,3 & 1,3 & 2,2 & 1,1 \\
\hline 9-M. M. S. & $-1,5$ & -6 & 3,4 & 1,2 & 8,6 & 4,8 \\
\hline 10-M. C. C. & 1,2 & $-5,3$ & 5,6 & 2,4 & 5,2 & 6,1 \\
\hline Nome paciente & VA-EIPTM & VP-EIPTM & PDMI-EIPTM & PDMS-EIPTM & LMDS-EIPTM & LMM-EIPTM \\
\hline 1-A. P. M. C. & 0,8 & $-0,1$ & 2,3 & 3,8 & $-1,6$ & -1 \\
\hline 2-A. P. S. R. & $-3,6$ & 0,4 & $-1,7$ & 0,5 & $-0,6$ & $-1,5$ \\
\hline 3-D. C. M. G. & $-0,6$ & $-0,5$ & $-0,2$ & 4 & 0,9 & $-0,8$ \\
\hline 4-D. J. S. & 1,2 & $-0,4$ & $-6,5$ & $-3,4$ & 1,9 & 0,3 \\
\hline 5-E. P. & $-1,4$ & $-0,5$ & $-2,6$ & $-0,4$ & 0,1 & 0,1 \\
\hline 6-E. F. S. & 0,6 & 1 & $-1,7$ & $-1,4$ & 0,8 & 0,6 \\
\hline 7-J. A. N. & 0,1 & $-0,6$ & $-2,9$ & 0,2 & 1,9 & 2,2 \\
\hline 8-М. А. О. & 0,1 & 0 & 0,8 & 1,2 & 0,1 & 0,8 \\
\hline 9-M. M. S. & 2,7 & 1 & $-2,8$ & $-1,7$ & -1 & -1 \\
\hline 10-M. C. C. & 1,9 & 0,4 & 0,9 & 3,1 & $-0,1$ & 0,4 \\
\hline
\end{tabular}


Tabela A - 18 - Resultados do $2^{\circ}$ traçado para o erro intra-examinador

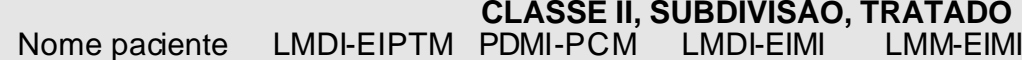

$\begin{array}{ll}\text { 1-A. P. M. C. } & -0,8 \\ \text { 2-A. P. S. R. } & -0,4 \\ \text { 3-D. C. M. G. } & 1,7 \\ \text { 4-D. J. S. } & 1,9 \\ \text { 5-E. P. } & 0,2 \\ \text { 6-E. F. S. } & 1,6 \\ \text { 7-J. A. N. } & 2, \\ \text { 8-M. A. O. } & -0,6 \\ \text { 9-M. M. S. } & -0,6 \\ \text { 10-M. C. C. } & 0,1\end{array}$

$\begin{array}{cc}-0,8 & -1,3 \\ -0,4 & 6,9 \\ 1,7 & 3,5 \\ 1,9 & 4,5 \\ 0,2 & 6,9 \\ 1,6 & 5,1 \\ 2,1 & 4,1 \\ -0,6 & 0,3 \\ -0,6 & 1,1 \\ 0,1 & 0,4\end{array}$

0,4
5,7
7
7
6,8
5,5
7
1
$-0,8$
0,8

LMDS-EIMI

LMDI-EIMS

5,7

3,5

4,5

6,9

4,1

0,3

0,4

0,2

4,6

4,4

5,3

6,6

4,6

7

2,3

$-1,2$

0,9

$-0,2$

5,9

6,6

7,2

7

5
7,3

7,3

1,9
$-1,3$

0,7

$-4,6$
0,1

$-0,9$

0,2

$-0,8$

2,1

0,3

$-5,7$

$-4,4$

Nome paciente

LMDS-EIMS

LMM-EIMS

$-4,8$

2-A. P. S. R.

3-D. C. M. G.

4-D. J. S.

5-E. P.

6-E. F. S.

7-J. A. N.

8-M. A. O.

9-M. M. S.

$-5,7$

0
$-1,8$

$-1,8$
0

$-0,8$

1,2

$-0,1$

$-5,5$

$-5,2$

$-5,5$

-1
$-3,4$

$-3,4$

$-1,3$

EIE.EIC

$-0,4$
0,6

2
0,9

$-0,8$

0,9

ETE.ETC

ETPTM.ETC

1,3

$-0,5$
1

2

0,9

1,9
$-0,2$

1,1

0,6

$-3,9$

$-4,6$

0

0,6

2,3

$-4,5$

2,3

2,4

1,7

$-0,3$

0,3

0,5

1,7

$-0,1$

$-0,3$

0,2

ETPTM.ETE

$-0,6$

$-0,1$

1,5

Nome paciente

1-A. P. M. C.

ETMI.ETE

ETMI.ETC

ETMI.ETPTM ETMS.ETE

ETMS.ETC

ETMS.ETPTM

$-7,6$

-2
$-6,6$

$-3,2$

$-9$

5,3

$-0,2$

$-6$

$-7,7$

$-3,3$

4-D. J. S.

$-4,2$

$-9,6$

6-E. F. S.

7-J. A. N.

8-M. A. O.

9-M. M. S.

10-M. C. C.

$-8$

$-5,6$

$-5,3$

$-4,7$

$-3,1$
$-8,3$

$-0,5$

3,9

$-0,2$

0,1

3,9

$-7$

$-1,2$

1,4

$-1,1$
1,7

$-0,1$

$-1,1$

6

5,1
4,6

4,8

0,8

1,5

4,8

1,3

0,6

3,3

5,9

6,6

5,8

1,8

1,4

$-0,3$

$-1,2$

$-1,2$

$-0,1$

2,3

0

$-1,8$

$-1$

$\begin{array}{lcccccc}\text { Nome paciente } & \text { PCM-LMM } & \text { PCM-CMM } & \text { POSMI } & \text { POSMS } & \text { ÂPLANOZ } & \text { ÂPLOCLUSAL } \\ \text { 1-A. P. M. C. } & -1,4 & -2,3 & -1,4 & -2,5 & 87,2 & 85,8 \\ \text { 2-A. P. S. R. } & 1,1 & 1,8 & -1,2 & 0,5 & 86,1 & 87,8 \\ \text { 3-D. C. M. G. } & -2,2 & -3,6 & 2,9 & -0,8 & 91,8 & 90 \\ \text { 4-D. J. S. } & -1,7 & 2,2 & -1,3 & 2,1 & 90,7 & 88,4 \\ \text { 5-E. P. } & -0,5 & -0,3 & 1,4 & 3,1 & 89,5 & 89,2 \\ \text { 6-E. F. S. } & -1,5 & -1,1 & -1,5 & 1,1 & 88 & 86,9 \\ \text { 7-J. A. N. } & -3,9 & -0,1 & 0,1 & 2,2 & 89,5 & 90,4 \\ \text { 8-M. A. O. } & -1,2 & -3,4 & 3,1 & 3,4 & 91,3 & 91,6 \\ \text { 9-M. M. S. } & 2,6 & 7,1 & -0,3 & 0,9 & 88,8 & 91,1 \\ \text { 10-M. C. C. } & -1,1 & -0,3 & -3,6 & -2,6 & 90,9 & 87,7\end{array}$


Tabela A - 19 - Resultados do $2^{\circ}$ traçado para o erro intra-examinador

\begin{tabular}{|c|c|c|c|c|c|c|}
\hline Nome paciente & ÂPLANTEG & $\begin{array}{c}\text { CLASSE II, S } \\
\text { DESVENA }\end{array}$ & $\begin{array}{l}\text { 3DIVISÃO, } \\
\text { DESMAND }\end{array}$ & $\begin{array}{r}\text { TADO } \\
\text { A1 }\end{array}$ & B1 & ÂANT \\
\hline 1-A. P. M. C. & 86,6 & $-3,6$ & $-2,5$ & -2 & $-2,7$ & $-4,8$ \\
\hline 2-A. P. S. R. & 90,8 & $-4,6$ & $-9,3$ & -6 & $-6,1$ & 5,3 \\
\hline 3-D. C. M. G. & 89,6 & 1,3 & 2,5 & 1,7 & 0,4 & $-5,2$ \\
\hline 4-D. J. S. & 89 & 0,9 & 4,2 & $-0,1$ & 0,1 & $-0,7$ \\
\hline 5-E. P. & 90,4 & 0 & $-0,9$ & $-0,8$ & $-0,8$ & $-2,2$ \\
\hline 6-E. F. S. & 90,6 & $-2,3$ & $-3,8$ & $-3,3$ & $-4,4$ & 4,5 \\
\hline 7-J. A. N. & 91,4 & $-1,4$ & $-4,4$ & $-3,4$ & $-4,6$ & $-1,1$ \\
\hline 8-М. А. О. & 87,8 & 2 & 3,4 & 2,9 & 2,6 & $-2,8$ \\
\hline 9-M. M. S. & 88,3 & $-1,2$ & $-1,1$ & -1 & -2 & $-4,2$ \\
\hline 10-M. С. С. & 89,1 & 0,5 & 2,5 & 2,6 & 2,4 & 0,6 \\
\hline Nome paciente & DISTZ & DISTCO & DISTZA & DISTNC & DISTJ & DISTAG \\
\hline 1-A. P. M. C. & 5 & 6,5 & 5,9 & 8 & 10,6 & 8,6 \\
\hline 2-A. P. S. R. & 1,8 & 10 & 7,5 & 7,2 & 8,6 & 13,9 \\
\hline 3-D. C. M. G. & $-0,6$ & $-1,7$ & $-0,3$ & 0,3 & 0,7 & $-0,8$ \\
\hline 4-D. J. S. & 0,8 & 0,7 & 0 & $-1,3$ & $-3,2$ & $-4,2$ \\
\hline 5-E. P. & 2,7 & 6,2 & 2,1 & 1,2 & 4 & 6,1 \\
\hline 6-E. F. S. & 1,6 & 2,4 & 2,1 & 2,4 & 4,6 & 4,3 \\
\hline 7-J. A. N. & 2,9 & 0,7 & 1,7 & 1,5 & 2,1 & 7,7 \\
\hline 8-М. А. О. & $-2,5$ & $-0,5$ & $-4,5$ & $-4,1$ & $-2,5$ & $-5,4$ \\
\hline 9-M. M. S. & 2 & $-3,7$ & -1 & 0,3 & $-0,3$ & 0,7 \\
\hline 10-M. C. C. & 0,5 & $-1,6$ & -7 & $-2,3$ & $-1,7$ & $-5,3$ \\
\hline Nome paciente & ALTA6 & CO-AG & CO-ME & ME-AG & & \\
\hline 1-A. P. M. C. & 3 & 2,5 & 2,6 & 2,5 & & \\
\hline 2-A. P. S. R. & 5,7 & 0 & 3,1 & 1 & & \\
\hline 3-D. C. M. G. & 2,6 & 1,7 & 0,9 & 2 & & \\
\hline 4-D. J. S. & $-0,9$ & $-3,2$ & -2 & 1,5 & & \\
\hline 5-E. P. & 5,4 & 0,6 & 3,1 & 3,8 & & \\
\hline 6-E. F. S. & 1 & $-3,4$ & $-1,9$ & $-0,7$ & & \\
\hline 7-J. A. N. & $-2,2$ & $-4,3$ & $-2,8$ & 2,1 & & \\
\hline 8-М. А. О. & $-1,6$ & 5,9 & 2,5 & -2 & & \\
\hline 9-M. M. S. & $-3,6$ & 3,2 & $-0,5$ & $-1,8$ & & \\
\hline 10-M. C. C. & 0 & 4,7 & 3,5 & $-1,3$ & & \\
\hline
\end{tabular}


Tabela A - 20 - Características dos pacientes do grupo com Classe II, subdivisão não tratado

\begin{tabular}{|c|c|c|c|c|c|}
\hline \multicolumn{6}{|c|}{ CLASSE II, SUBDIVISÃO NÃO TRATADO } \\
\hline Paciente & D.N. & Data $R x$ & Idade & Direito & Esquerdo \\
\hline 1- A. B. & 14.08 .83 & 13.04 .96 & 12,67 & Classe I & Classe II \\
\hline 2- A. E. & 19.03 .81 & 12.12 .95 & 14,74 & Classe I & Classe II \\
\hline 3- A. N. P. M. & 12.07 .80 & 13.04 .96 & 15,76 & Classe I & Classe II \\
\hline 4- A. L. G. S. & 29.04 .84 & 12.06 .96 & 12,12 & Classe II & Classe I \\
\hline 5- A.P. F.R. & 06.08 .73 & 13.04 .96 & 22,70 & Classe I & Classe II \\
\hline 6- A. G. & 19.05 .76 & 10.08 .96 & 20,24 & Classe II & Classe I \\
\hline 7- A. C. M. Jr. & 05.11 .83 & 06.04 .96 & 12,42 & Classe I & Classe II \\
\hline 8- B. P. L. & 12.05 .83 & 02.06 .95 & 12,06 & Classe I & Classe II \\
\hline 9- C. Q. & 10.10 .83 & 02.04 .96 & 12,48 & Classe I & Classe II \\
\hline 10- C. B.S. & 25.07 .80 & 30.03 .96 & 15,69 & Classe I & Classe II \\
\hline 11- C. A. A. & 09.06 .76 & 07.10 .95 & 19,33 & Classe II & Classe I \\
\hline 12- D. F. R. S. & 05.05 .79 & 14.02 .96 & 16,79 & Classe I & Classe II \\
\hline 13- D. M. B. & 04.09 .76 & 15.02 .96 & 19,46 & Classe II & Classe I \\
\hline 14- D. M R. & 27.04 .64 & 26.03 .96 & 31,93 & Classe I & Classe II \\
\hline 15- E. Y. Y. & 06.02 .83 & 06.04 .96 & 13,17 & Classe I & Classe II \\
\hline 16- E.P. & 03.03 .81 & 04.04 .96 & 15,09 & Classe II & Classe I \\
\hline 17- F.S.S. & 11.05 .83 & 06.04 .96 & 12,91 & Classe I & Classe II \\
\hline 18- I. A. & 22.09 .81 & 19.06 .95 & 13,74 & Classe II & Classe I \\
\hline 19- L. C. C. S. & 20.10 .83 & 09.02 .96 & 12,31 & Classe II & Classe I \\
\hline 20- M. A. O. F. & 26.09 .81 & 08.02 .96 & 14,37 & Classe II & Classe I \\
\hline 21 - M. L. P. & 21.11 .76 & 20.06 .95 & 18,58 & Classe II & Classe I \\
\hline 22- M. M. S. & 01.08 .82 & 06.04 .96 & 13,69 & Classe II & Classe I \\
\hline 23- N. C. R. & 20.06 .83 & 06.04 .96 & 12,80 & Classe II & Classe I \\
\hline 24- P. S. D. & 02.02 .81 & 30.03 .96 & 15,16 & Classe II & Classe I \\
\hline 25- R. M. G. & 04.05 .83 & 06.04 .96 & 12,93 & Classe II & Classe I \\
\hline 26- R. C. M. & 07.01 .79 & 08.02 .96 & 17,09 & Classe I & Classe II \\
\hline 27- R. D. P. & 07.08 .81 & 19.06.95 & 13,87 & Classe I & Classe II \\
\hline 28- S. F. A. & 07.05 .84 & 30.03 .96 & 11,90 & Classe II & Classe I \\
\hline 29- S. A. P. & 30.01 .76 & 08.06 .96 & 20,36 & Classe I & Classe II \\
\hline 30- W. R. C. & 19.12 .78 & 02.06 .95 & 16,46 & Classe I & Classe II \\
\hline Média: & & & 15,76 & & \\
\hline
\end{tabular}

As tabelas A - 21 a A - 36 consistem dos valores reais individuais de cada variável, para cada paciente, do grupo de Classe II, subdivisão não tratado

Tabela A - 21

\begin{tabular}{|c|c|c|c|c|c|c|c|}
\hline \multirow{2}{*}{ Paciente } & \multicolumn{6}{|c|}{ CLASSE II, SUBDIVISÃO NÃO TRATADO } & \multirow[b]{2}{*}{ PDMS-ETC } \\
\hline & Número & Grupo & Sexo & GO-ETC & PPC-ETC & PDMI-ETC & \\
\hline 1-A.B. & 31 & 2 & M & 2,8 & $-1,2$ & 5,0 & 1,5 \\
\hline 2- A. E. & 32 & 2 & $\mathrm{~F}$ & $-0,7$ & 3,6 & 4,9 & $-0,3$ \\
\hline 3- A. N.P.M. & 33 & 2 & $\mathrm{~F}$ & $-2,3$ & 4,5 & 2,0 & $-0,8$ \\
\hline 4- A. L. G. S. & 34 & 2 & $\mathrm{~F}$ & 2,5 & 2,2 & 4,1 & 2,4 \\
\hline 5- A.P. F. R. & 35 & 2 & $\mathrm{~F}$ & 0,6 & 0,5 & 2,1 & $-1,2$ \\
\hline 6- A. G. & 36 & 2 & M & 2,3 & 2,4 & 5,1 & 2,2 \\
\hline 7- A. C. M. Jr. & 37 & 2 & $\mathrm{M}$ & 0,1 & $-1,6$ & 2,8 & $-2,8$ \\
\hline 8- B. P. L. & 38 & 2 & $\mathrm{~F}$ & 2,2 & $-2,2$ & 0,1 & $-1,3$ \\
\hline 9- C. Q. & 39 & 2 & $\mathrm{~F}$ & 2,8 & 1,1 & 2,6 & $-1,2$ \\
\hline 10- C. B. S. & 40 & 2 & $\mathrm{M}$ & 0,9 & 2,1 & 4,4 & 0,8 \\
\hline 11- C. A. A. & 41 & 2 & M & 0,2 & $-2,4$ & 1,9 & $-0,8$ \\
\hline 12- D. F. R. S. & 42 & 2 & $\mathrm{M}$ & $-1,4$ & $-1,9$ & 3,5 & $-1,1$ \\
\hline 13- D. M. B. & 43 & 2 & $\mathrm{~F}$ & $-1,1$ & $-3,3$ & 0,2 & $-2,2$ \\
\hline 14- D. M R. & 44 & 2 & $\mathrm{~F}$ & 0,6 & 1,6 & 1,5 & $-1,4$ \\
\hline 15- E. Y. Y. & 45 & 2 & $\mathrm{M}$ & 1,2 & $-0,6$ & 1,4 & $-0,6$ \\
\hline 16- E.P. & 46 & 2 & $\mathrm{~F}$ & 1,5 & 1,3 & 1,9 & 0,3 \\
\hline 17- F. S. S. & 47 & 2 & M & 1,9 & 0,1 & 1,5 & $-1,2$ \\
\hline 18- I. A. & 48 & 2 & $\mathrm{M}$ & 0,1 & 2,7 & 3,7 & $-0,1$ \\
\hline 19- L. C. C. S. & 49 & 2 & M & 1,4 & $-0,2$ & 3,5 & $-2,2$ \\
\hline 20- M. A. O. F. & 50 & 2 & $\mathrm{M}$ & 0,3 & 0,7 & 3,1 & $-1,7$ \\
\hline 21- M. L.P. & 51 & 2 & M & $-0,7$ & $-0,1$ & 3,5 & $-0,9$ \\
\hline 22- M. M. S. & 52 & 2 & $\mathrm{~F}$ & 0,9 & 1,7 & 0,1 & $-2,9$ \\
\hline 23- N. C. R. & 53 & 2 & $\mathrm{~F}$ & $-3,8$ & $-2,3$ & $-0,4$ & $-3,7$ \\
\hline 24- P. S. D. & 54 & 2 & $\mathrm{~F}$ & $-1,1$ & $-1,1$ & 2,7 & $-3,2$ \\
\hline 25- R. M. G. & 55 & 2 & $\mathrm{M}$ & $-0,3$ & $-1,1$ & 1,1 & $-1,6$ \\
\hline 26- R. C. M. & 56 & 2 & M & 0,1 & $-1,3$ & 1,7 & $-1,9$ \\
\hline 27- R. D. P. & 57 & 2 & M & $-1,6$ & $-1,7$ & 5,3 & $-1,8$ \\
\hline 28- S. F. A. & 58 & 2 & $\mathrm{~F}$ & 1,2 & 0,3 & 3,7 & $-2,0$ \\
\hline 29- S. A.P. & 59 & 2 & $\mathrm{~F}$ & 0,5 & $-0,3$ & 1,0 & 0,0 \\
\hline 30- W. R. C. & 60 & 2 & $\mathrm{M}$ & 2,8 & 1,0 & 3,9 & 0,5 \\
\hline
\end{tabular}


Tabela A - 22

\begin{tabular}{|c|c|c|c|c|c|c|c|}
\hline \multicolumn{8}{|c|}{ CLASSE II, SUBDIVISÃO NÃO TRATADO } \\
\hline Paciente & GO-EIC & PPC-EIC & PDMIEIC & PDMS-EIC & LMM-EIC & LMDI-EIC & LMDS-EIC \\
\hline 1-A. B. & $-1,3$ & 6,1 & 0,2 & 2,0 & $-2,7$ & $-2,6$ & $-0,4$ \\
\hline 2- A. E. & 3,8 & 0,5 & 1,2 & 5,1 & $-0,3$ & $-0,9$ & 1,2 \\
\hline 3- A. N.P. M. & 0,1 & $-3,9$ & $-7,0$ & $-3,8$ & $-8,5$ & $-6,4$ & $-2,7$ \\
\hline 4- A. L. G. S. & 7,2 & $-0,5$ & 2,2 & 2,9 & 0,2 & $-2,1$ & 0,3 \\
\hline 5- A.P. F. R. & $-1,1$ & 1,7 & $-2,1$ & $-2,0$ & $-2,4$ & $-1,6$ & 0,0 \\
\hline 6- A. G. & 0,2 & 0,5 & $-6,1$ & $-5,8$ & $-6,5$ & $-5,3$ & $-4,5$ \\
\hline 7- A. C. M. Jr. & $-1,7$ & $-0,4$ & $-0,4$ & 1,5 & $-0,9$ & $-0,4$ & 0,6 \\
\hline 8- B. P. L. & $-1,5$ & $-1,1$ & $-4,0$ & $-0,6$ & $-2,0$ & $-1,9$ & 0,3 \\
\hline 9- C. Q. & $-3,8$ & $-1,6$ & 1,7 & 3,5 & 0,2 & 0,8 & 0,5 \\
\hline 10- C. B. S. & 1,8 & $-2,4$ & 1,3 & 2,9 & 1,7 & 1,5 & 3,5 \\
\hline 11- C. A. A. & 0,9 & 2,8 & 1,5 & 3,7 & 2,0 & $-0,3$ & 2,6 \\
\hline 12- D. F. R. S. & 1,7 & $-1,0$ & $-2,5$ & 2,9 & 0,0 & $-1,7$ & 0,1 \\
\hline 13- D. M. B. & 6,4 & 0,7 & $-1,3$ & 0,1 & $-2,0$ & $-0,7$ & 1,1 \\
\hline 14- D. M R & $-2,9$ & $-1,2$ & $-5,7$ & $-3,7$ & $-5,8$ & $-4,3$ & $-1,0$ \\
\hline 15- E. Y. Y. & $-2,7$ & 2,2 & $-2,8$ & 0,6 & $-3,5$ & $-0,1$ & 2,2 \\
\hline 16- E.P. & 1,5 & $-0,4$ & $-2,9$ & $-1,0$ & $-2,9$ & $-2,5$ & $-0,2$ \\
\hline 17- F.S.S. & 1,5 & 4,1 & 6,0 & 5,7 & 3,7 & 2,7 & 4,3 \\
\hline 18-I. A. & 6,4 & 4,4 & 6,2 & 6,3 & 2,6 & 1,7 & 2,5 \\
\hline 19- L. C. C. S. & 2,9 & 6,4 & 8,9 & 9,5 & 6,6 & 3,9 & 6,6 \\
\hline 20- M. A. O. F. & 0,3 & 0,9 & 6,1 & 4,3 & 2,5 & 1,2 & 3,1 \\
\hline 21- M. L.P. & $-1,8$ & $-4,5$ & $-5,2$ & $-4,7$ & $-2,8$ & $-4,0$ & $-1,5$ \\
\hline 22- M. M. S. & $-0,5$ & $-0,2$ & $-3,7$ & $-4,6$ & $-2,9$ & $-2,4$ & $-1,4$ \\
\hline 23- N. C. R. & 0,2 & 0,7 & 0,0 & 0,9 & 2,2 & 1,1 & 3,9 \\
\hline 24- P. S. D. & $-0,3$ & $-1,1$ & 1,1 & 0,5 & 0,7 & $-0,8$ & 1,8 \\
\hline 25- R. M. G. & $-6,2$ & $-4,1$ & $-3,4$ & $-0,1$ & 0,0 & $-1,1$ & 0,2 \\
\hline 26- R. C. M. & $-1,6$ & 0,5 & $-3,5$ & 1,2 & $-2,1$ & $-1,0$ & 0,7 \\
\hline 27- R. D. P. & $-2,5$ & $-0,6$ & $-6,8$ & $-3,6$ & 0,0 & $-4,7$ & $-0,3$ \\
\hline 28- S. F. A. & 3,2 & 0,5 & 0,7 & 3,3 & $-0,9$ & $-0,7$ & 2,7 \\
\hline 29- S. A.P. & 2,9 & 3,1 & 2,0 & 3,6 & 0,4 & 0,4 & 2,2 \\
\hline 30- W. R. C. & $-9,0$ & $-3,6$ & $-12,6$ & $-9,0$ & $-11,6$ & $-7,4$ & $-5,7$ \\
\hline
\end{tabular}

Tabela A - 23

\begin{tabular}{|c|c|c|c|c|c|c|c|}
\hline \multicolumn{8}{|c|}{ CLASSE II, SUBDIVISÃO NÃO TRATADO } \\
\hline Paciente & PCM-ETE & GO-ETE & PPC-ETE & PDMI-ETE & PDMS-ETE & ACP-ETE & FCM-ETE \\
\hline 1- A. B. & 2,6 & 0,4 & $-3,4$ & 3,6 & 0,1 & $-0,7$ & $-1,0$ \\
\hline 2- A. E. & $-0,5$ & $-0,3$ & 4,0 & 5,1 & 0,0 & $-0,5$ & 5,9 \\
\hline 3- A. N. P. M. & $-1,8$ & $-0,5$ & 6,0 & 3,0 & 0,2 & $-1,2$ & 0,2 \\
\hline 4- A. L. G. S. & $-1,1$ & 3,6 & 3,2 & 4,7 & 3,0 & 0,1 & 2,8 \\
\hline 5- A.P.F.R. & $-0,8$ & 1,4 & 1,2 & 2,5 & $-0,8$ & $-2,6$ & 2,5 \\
\hline 6- A. G. & 1,3 & 1,1 & 1,2 & 4,4 & 1,5 & 0,4 & $-3,6$ \\
\hline 7- A. C. M. Jr. & $-6,1$ & 6,0 & 4,0 & 6,0 & 0,4 & $-1,8$ & 4,8 \\
\hline 8- B. P. L. & 0,2 & 2,0 & $-2,4$ & 0,0 & $-1,4$ & $-0,6$ & 2,2 \\
\hline 9- C. Q. & 0,2 & 2,6 & 0,9 & 2,5 & $-1,3$ & $-0,4$ & $-1,1$ \\
\hline 10- C.B. S. & 0,4 & 0,6 & 1,7 & 4,2 & 0,6 & $-0,1$ & 5,1 \\
\hline 11- C. A. A. & $-0,7$ & 0,9 & $-1,7$ & 2,3 & $-0,4$ & 2,6 & 0,7 \\
\hline 12- D. F. R. S. & $-2,5$ & 1,2 & 0,4 & 4,8 & 0,2 & 7,2 & 3,1 \\
\hline 13- D. M. B. & 0,2 & $-1,3$ & $-3,5$ & 0,1 & $-2,3$ & 0,7 & $-2,7$ \\
\hline 14- D. M R. & 2,2 & $-1,4$ & $-0,3$ & 0,5 & $-2,4$ & $-0,7$ & $-3,8$ \\
\hline 15- E. Y. Y. & $-2,1$ & 3,3 & 1,5 & 2,4 & 0,5 & 1,0 & 6,9 \\
\hline 16- E.P. & $-2,7$ & 4,0 & 3,7 & 3,2 & 1,6 & 0,9 & 0,2 \\
\hline 17- F. S. S. & $-0,6$ & 2,6 & 0,7 & 1,9 & $-0,8$ & $-1,3$ & 0,7 \\
\hline 18- I. A. & 2,0 & $-1,9$ & 1,1 & 2,8 & $-1,1$ & $-0,5$ & $-1,9$ \\
\hline 19- L. C. C. S. & $-1,7$ & 3,1 & 1,3 & 4,3 & $-1,4$ & $-2,9$ & 2,3 \\
\hline 20- M. A. O. F. & $-0,9$ & 1,2 & 1,6 & 3,5 & $-1,2$ & 0,3 & $-2,9$ \\
\hline 21 - M. L. P. & $-2,3$ & 1,6 & 2,1 & 4,7 & 0,3 & 0,5 & $-1,7$ \\
\hline 22- M. M. S. & $-1,3$ & 2,1 & 2,8 & 0,7 & $-2,3$ & 0,5 & $-2,3$ \\
\hline 23- N. C. R. & $-4,3$ & 0,3 & 1,8 & 1,7 & $-1,6$ & 0,5 & $-0,9$ \\
\hline 24- P. S. D. & 0,5 & $-1,6$ & $-1,6$ & 2,5 & $-3,5$ & 0,8 & $-3,3$ \\
\hline 25- R. M. G. & 0,6 & $-0,9$ & $-1,6$ & 0,8 & $-1,8$ & 12,0 & $-2,4$ \\
\hline 26- R. C. M. & $-0,3$ & 0,4 & $-1,0$ & 1,9 & $-1,8$ & 0,7 & $-3,3$ \\
\hline 27- R. D. P. & 3,5 & $-5,0$ & $-4,9$ & 3,3 & $-3,8$ & 1,4 & $-6,1$ \\
\hline 28- S. F. A. & $-1,7$ & 2,8 & 1,9 & 4,6 & $-1,1$ & $-0,2$ & $-2,0$ \\
\hline 29- S. A.P. & $-1,1$ & 1,5 & 0,7 & 1,5 & 0,6 & $-0,8$ & 0,2 \\
\hline 30- W. R. C. & 1,4 & 1,4 & $-0,4$ & 3,2 & $-0,3$ & $-0,6$ & $-0,8$ \\
\hline
\end{tabular}


Tabela A - 24

\begin{tabular}{|c|c|c|c|c|c|c|c|}
\hline & & CLASS & UBDIVISÃ & IÃO TRATAD & & & \\
\hline Paciente & PCM-EIE & $\begin{array}{c}\text { GO-EIE } \\
-23\end{array}$ & PPC-EIE & PDMI-EIE & PDMS-EIE & LMM-EIE & LMDI-EIE \\
\hline $\begin{array}{l}\text { 1- A. B. } \\
\text { 2- A. E. }\end{array}$ & $\begin{array}{l}-1,5 \\
-0,8\end{array}$ & $\begin{array}{r}-2,3 \\
2,8\end{array}$ & $\begin{array}{r}6,4 \\
-1,0\end{array}$ & $\begin{array}{r}1,1 \\
-0,5\end{array}$ & $\begin{array}{l}2,9 \\
3,4\end{array}$ & $\begin{array}{l}-1,3 \\
-1,4\end{array}$ & $\begin{array}{l}-1,3 \\
-2,0\end{array}$ \\
\hline 3- A. N. P. M. & $-0,2$ & $-1,2$ & $-6,1$ & $-9,7$ & $-6,5$ & $-10,5$ & $-8,3$ \\
\hline 4- A. L. G. S. & $-2,0$ & 4,1 & $-4,0$ & $-1,5$ & $-0,8$ & $-1,9$ & $-4,1$ \\
\hline 5- A. P. F. R. & $-0,5$ & $-1,6$ & 0,9 & $-3,0$ & $-2,9$ & $-2,9$ & $-2,1$ \\
\hline 6- A. G. & $-0,3$ & $-1,5$ & 0,1 & $-5,8$ & $-5,5$ & $-5,7$ & $-4,5$ \\
\hline 7- A. C. M. Jr. & $-1,9$ & $-3,9$ & $-6,5$ & $-8,0$ & $-6,2$ & $-6,7$ & $-6,3$ \\
\hline 8- B. P. L. & $-0,3$ & $-2,7$ & $-2,3$ & $-5,2$ & $-1,8$ & $-2,6$ & $-2,5$ \\
\hline 9- C. Q. & 0,3 & $-3,8$ & $-1,5$ & 2,0 & 3,8 & 0,5 & 1,0 \\
\hline 10- C. B. S. & 4,5 & 5,7 & 1,3 & 4,8 & 6,4 & 3,4 & 3,1 \\
\hline 11- C. A. A. & 2,9 & 3,5 & 5,1 & 3,4 & 5,6 & 2,8 & 0,4 \\
\hline 12- D. F. R. S. & $-0,2$ & 1,6 & $-2,7$ & $-5,1$ & 0,3 & $-2,1$ & $-3,7$ \\
\hline 13- D. M. B. & $-1,8$ & 4,8 & $-0,6$ & $-2,5$ & $-1,1$ & $-2,4$ & $-1,1$ \\
\hline 14- D. M R. & 1,6 & $-1,5$ & 1,0 & $-3,1$ & $-1,1$ & $-4,0$ & $-2,5$ \\
\hline 15- E. Y. Y. & 1,2 & $-1,2$ & 2,6 & $-2,6$ & 0,7 & $-4,0$ & $-0,4$ \\
\hline 16- E.P. & 0,8 & 1,0 & $-2,4$ & $-5,6$ & $-3,7$ & $-5,1$ & $-4,7$ \\
\hline 17- F.S.S. & $-0,5$ & 0,6 & 2,8 & 4,5 & 4,2 & 2,7 & 1,8 \\
\hline 18- I. A. & $-3,8$ & 3,1 & 2,5 & 4,8 & 5,0 & 2,6 & 1,7 \\
\hline 19- L. C. C. S. & $-2,0$ & 0,4 & 2,9 & 4,8 & 5,4 & 4,0 & 1,2 \\
\hline 20- M. A. O. F. & 2,1 & 2,0 & 1,5 & 6,5 & 4,7 & 2,3 & 0,9 \\
\hline 21 - M. L. P. & $-2,5$ & $-4,3$ & $-8,2$ & $-9,4$ & $-8,9$ & $-5,4$ & $-6,6$ \\
\hline 22- M. M. S. & 1,0 & $-0,7$ & $-1,2$ & $-5,2$ & $-6,1$ & $-4,1$ & $-3,6$ \\
\hline 23- N. C. R. & 3,5 & 3,3 & 1,6 & $-0,3$ & 0,6 & 0,8 & $-0,5$ \\
\hline 24- P. S. D. & 0,2 & $-0,5$ & $-1,0$ & 1,2 & 0,6 & 0,9 & $-0,7$ \\
\hline 25- R. M. G. & 1,8 & $-4,7$ & $-1,8$ & $-0,7$ & 2,6 & 1,7 & 0,7 \\
\hline 26- R. C. M. & $-1,1$ & $-2,6$ & $-0,7$ & $-4,8$ & $-0,2$ & $-2,9$ & $-1,8$ \\
\hline 27- R. D. P. & 1,6 & $-0,3$ & 4,4 & $-0,6$ & 2,7 & 4,5 & $-0,1$ \\
\hline 28- S. F. A. & 1,6 & 4,3 & 0,8 & 0,6 & 3,2 & $-1,3$ & $-1,2$ \\
\hline 29- S. A.P. & $-1,0$ & 1,1 & 1,1 & $-0,1$ & 1,5 & $-0,8$ & $-0,8$ \\
\hline 30- W. R. C. & 0,2 & $-10,1$ & $-2,6$ & $-11,5$ & $-7,9$ & $-10,5$ & $-6,1$ \\
\hline
\end{tabular}

Tabela A - 25

\begin{tabular}{|c|c|c|c|c|c|c|c|}
\hline & & CLASSE & JBDIVISÃC & O TRATAL & & & \\
\hline Paciente & LMDS-EIE & ACP-EIE & FCM-EIE & BA-EIE & OP-EIE & BC-ETPTM & Z-ETPTM \\
\hline 1- A. B. & 1,1 & $-2,8$ & 4,9 & $-2,0$ & $-2,6$ & $-3,4$ & 0,5 \\
\hline 2- A. E. & 0,0 & $-4,4$ & $-0,5$ & 0,7 & 0,6 & 0,5 & 3,4 \\
\hline 3- A. N. P. M. & $-4,7$ & $-2,6$ & $-7,0$ & $-0,1$ & $-0,9$ & $-0,4$ & $-6,3$ \\
\hline 4- A. L. G. S. & $-1,8$ & 2,6 & $-0,5$ & 2,9 & 3,4 & 2,8 & 1,7 \\
\hline 5- A. P. F. R. & $-0,6$ & 5,6 & 0,2 & $-0,9$ & $-1,2$ & $-0,2$ & 0,9 \\
\hline 6- A. G. & $-3,7$ & 0,8 & 0,6 & $-7,0$ & $-6,3$ & $-0,7$ & 0,7 \\
\hline 7- A. C. M. Jr. & $-5,5$ & 2,6 & $-6,0$ & $-1,9$ & $-1,0$ & 3,5 & $-0,6$ \\
\hline 8- B. P. L. & $-0,3$ & 0,9 & $-3,5$ & $-2,4$ & $-3,2$ & $-6,8$ & $-1,5$ \\
\hline 9- C. Q. & 0,8 & $-4,2$ & $-3,2$ & $-2,7$ & $-2,5$ & $-1,9$ & $-1,1$ \\
\hline 10- C. B. S. & 5,0 & $-2,3$ & 10,8 & 3,2 & 3,8 & 2,9 & $-1,0$ \\
\hline 11- C. A. A. & 3,4 & $-2,1$ & 1,0 & 3,2 & 2,9 & 5,9 & $-2,5$ \\
\hline 12- D. F. R.S. & $-2,1$ & $-2,6$ & $-2,4$ & 1,1 & 0,5 & 0,4 & 0,8 \\
\hline 13- D. M. B. & 0,7 & $-6,8$ & 4,9 & $-2,6$ & $-4,3$ & $-5,1$ & 5,0 \\
\hline 14- D. M R. & 0,8 & $-0,6$ & 4,2 & $-1,2$ & $-2,1$ & $-4,7$ & 8,8 \\
\hline 15- E. Y. Y. & 1,7 & 2,6 & 3,8 & $-0,8$ & $-0,7$ & 3,1 & $-1,4$ \\
\hline 16- E.P. & $-2,7$ & 3,6 & 3,0 & $-0,1$ & $-0,4$ & 1,3 & 0,6 \\
\hline 17- F. S. S. & 3,3 & $-2,6$ & 6,4 & $-1,7$ & $-1,0$ & $-1,2$ & 0,0 \\
\hline 18- I. A. & 2,7 & $-6,4$ & 0,1 & 1,5 & 0,6 & 0,0 & 0,6 \\
\hline 19- L. C. C. S. & 3,8 & $-4,5$ & $-0,7$ & 3,0 & 3,0 & 5,5 & $-0,8$ \\
\hline 20- M. A. O. F. & 2,7 & $-6,4$ & 1,1 & $-0,5$ & $-0,8$ & $-0,3$ & $-6,9$ \\
\hline 21 - M. L. P. & $-4,2$ & 1,6 & $-0,1$ & $-1,1$ & $-0,4$ & $-3,2$ & 0,8 \\
\hline 22- M. M. S. & $-2,6$ & 5,0 & 10,0 & $-0,4$ & 0,5 & 2,1 & 1,4 \\
\hline 23- N. C. R. & 2,2 & $-1,1$ & 2,8 & 0,6 & 0,3 & 1,5 & 10,2 \\
\hline 24- P. S. D. & 1,9 & $-1,5$ & 3,7 & $-0,5$ & $-2,3$ & 3,1 & $-0,9$ \\
\hline 25- R. M. G. & 2,0 & 2,6 & 12,1 & $-2,6$ & $-5,6$ & 0,9 & 0,7 \\
\hline 26- R. C. M. & $-0,1$ & 1,1 & 1,2 & $-6,5$ & $-7,0$ & $-3,3$ & 0,1 \\
\hline 27- R. D. P. & 4,5 & $-4,3$ & 8,3 & $-0,5$ & $-3,4$ & 3,7 & 0,7 \\
\hline 28- S. F. A. & 2,1 & $-3,1$ & $-0,8$ & 0,2 & $-0,6$ & 0,5 & 1,6 \\
\hline 29- S. A. P. & 1,0 & $-1,1$ & $-2,5$ & 1,1 & 1,7 & $-1,0$ & $-0,2$ \\
\hline 30- W. R. C. & $-4,2$ & 4,8 & 2,6 & $-2,4$ & $-3,9$ & $-4,3$ & 8,2 \\
\hline
\end{tabular}


Tabela A - 26

\begin{tabular}{|c|c|c|c|c|c|c|}
\hline \multicolumn{7}{|c|}{ CLASSE II, SUBDIVISÃO NÃO TRATADO } \\
\hline Paciente & ACA-ETPTM & A-ETPTM & PDMI-ETPTM & PDMS-ETPTM & BC-EIPTM & Z-EIPTM \\
\hline 1-A. B. & 1,0 & 0,0 & 3,7 & 0,2 & 2,7 & $-1,2$ \\
\hline 2- A. E. & 3,1 & 0,2 & 4,4 & $-0,8$ & 1,4 & 4,0 \\
\hline 3- A. N.P.M. & $-5,6$ & 3,9 & 2,3 & $-0,4$ & $-4,5$ & $-2,7$ \\
\hline 4- A. L. G. S. & 1,5 & 0,7 & 4,0 & 2,3 & $-1,4$ & $-3,3$ \\
\hline 5- A.P.F.R. & 1,1 & 0,1 & 1,7 & $-1,6$ & 3,7 & 1,3 \\
\hline 6- A. G. & 0,8 & $-0,2$ & 4,0 & 1,1 & 0,6 & 0,5 \\
\hline 7- A. C. M. Jr. & $-0,5$ & 7,2 & 5,8 & 0,3 & 2,6 & 11,8 \\
\hline 8- B. P. L. & $-1,2$ & $-3,9$ & $-0,5$ & $-1,9$ & 3,3 & 4,2 \\
\hline 9- C. Q. & $-1,3$ & $-3,4$ & 2,1 & $-1,7$ & 2,1 & $-2,0$ \\
\hline 10- C.B.S. & $-0,8$ & 2,6 & 6,1 & 2,5 & $-0,4$ & $-0,4$ \\
\hline 11- C. A. A. & $-2,3$ & 5,0 & 4,0 & 1,4 & $-1,3$ & 0,4 \\
\hline 12- D. F. R.S. & 0,9 & 0,8 & 5,2 & 0,5 & $-1,4$ & $-0,3$ \\
\hline 13- D. M. B. & 4,4 & $-2,7$ & $-1,4$ & $-3,8$ & 2,2 & $-4,3$ \\
\hline 14- D. M R. & 8,4 & $-3,7$ & $-0,7$ & $-3,6$ & 4,7 & 0,1 \\
\hline 15- E. Y.Y. & $-1,0$ & 2,4 & 2,9 & 1,0 & $-0,7$ & $-0,7$ \\
\hline 16- E.P. & 0,6 & 0,4 & 1,9 & 0,3 & 2,9 & $-0,1$ \\
\hline 17- F.S.S. & 0,3 & $-0,9$ & 2,0 & $-0,7$ & 2,0 & 1,1 \\
\hline 18- I. A. & 0,6 & 0,0 & 3,8 & $-0,1$ & $-4,4$ & $-0,9$ \\
\hline 19- L. C. C. S. & $-0,6$ & 5,9 & 5,9 & 0,3 & $-2,3$ & $-3,5$ \\
\hline 20- M. A. O. F. & $-6,6$ & $-0,6$ & 3,7 & $-1,1$ & 0,7 & $-0,5$ \\
\hline 21- M. L.P. & 0,8 & $-3,8$ & 1,9 & $-2,6$ & 2,3 & 0,4 \\
\hline 22- M. M. S. & 1,3 & 4,1 & 1,0 & $-2,0$ & 2,2 & 4,4 \\
\hline 23- N. C. R. & 9,5 & 1,8 & 1,7 & $-1,6$ & 1,1 & 2,9 \\
\hline 24- P. S. D. & $-0,5$ & 1,2 & 4,5 & $-1,4$ & 0,7 & 3,8 \\
\hline 25- R. M. G. & 0,4 & 0,6 & 2,0 & $-0,5$ & 4,6 & 5,7 \\
\hline 26- R. C. M. & 0,4 & $-3,8$ & 1,0 & $-2,6$ & 3,0 & $-0,9$ \\
\hline 27- R. D. P. & 0,8 & 4,1 & 8,5 & 1,4 & 0,6 & 3,5 \\
\hline 28- S. F. A. & 1,4 & 1,1 & 4,5 & $-1,2$ & $-1,6$ & $-2,2$ \\
\hline 29- S. A.P. & $-0,5$ & $-0,9$ & 0,8 & $-0,2$ & $-1,8$ & 0,2 \\
\hline 30- W. R. C. & 7,5 & 0,7 & 2,7 & $-0,8$ & 5,2 & 14,0 \\
\hline
\end{tabular}

Tabela A - 27

\begin{tabular}{|c|c|c|c|c|c|c|}
\hline \multicolumn{7}{|c|}{ CLASSE II, SUBDIVISÃO NÃO TRATADO } \\
\hline Paciente & ACA-EIPTM & A-EIPTM & VA-EIPTM & VP-EIPTM & PDMIEIPTM & PDMS-EIPTM \\
\hline 1 - A. B. & $-1,7$ & $-1,3$ & 0,1 & $-0,8$ & $-0,8$ & 0,9 \\
\hline 2- A. E. & $-2,5$ & $-0,1$ & 2,5 & 0,7 & 3,8 & 7,7 \\
\hline 3- A. N.P.M. & $-5,7$ & $-7,3$ & $-0,1$ & $-0,1$ & $-7,3$ & $-4,1$ \\
\hline 4- A. L. G. S. & $-0,7$ & $-1,2$ & 0,5 & 1,0 & 0,2 & 0,9 \\
\hline 5- A.P. F. R. & 8,1 & 2,9 & 0,0 & $-0,1$ & $-1,6$ & $-1,4$ \\
\hline 6- A. G. & 6,0 & 3,4 & $-2,1$ & $-1,1$ & $-5,8$ & $-5,5$ \\
\hline 7- A. C. M. Jr. & 11,7 & 1,3 & 1,3 & 2,1 & 2,0 & 3,9 \\
\hline 8- B. P. L. & 3,1 & 3,4 & 1,2 & $-0,1$ & $-0,9$ & 2,5 \\
\hline 9- C. Q. & $-1,6$ & 1,1 & 0,5 & 0,0 & 1,5 & 3,3 \\
\hline 10- C. B. S. & $-3,7$ & $-1,3$ & $-0,9$ & $-0,1$ & 2,2 & 3,8 \\
\hline 11- C. A. A. & $-5,6$ & $-1,5$ & 2,2 & 1,6 & 3,0 & 5,2 \\
\hline 12- D. F. R. S. & $-5,7$ & $-3,8$ & $-0,3$ & 1,4 & $-4,5$ & 0,9 \\
\hline 13- D. M. B. & $-1,4$ & 0,8 & 0,8 & $-0,1$ & $-3,3$ & $-2,0$ \\
\hline 14- D. M R. & 0,2 & 5,0 & 2,4 & $-1,2$ & $-3,9$ & $-1,9$ \\
\hline 15- E. Y. Y. & 4,3 & 1,3 & 1,5 & $-0,3$ & $-5,2$ & $-1,9$ \\
\hline 16- E.P. & 1,1 & 0,1 & $-0,9$ & $-0,1$ & $-2,9$ & $-1,0$ \\
\hline 17- F. S. S. & 1,0 & 1,9 & 1,0 & 0,8 & 4,1 & 3,8 \\
\hline 18- I. A. & $-9,6$ & $-4,3$ & $-0,4$ & $-0,5$ & 0,2 & 0,3 \\
\hline 19- L. C. C. S. & $-2,6$ & $-2,5$ & $-0,5$ & $-0,6$ & 0,8 & 1,2 \\
\hline 20- M. A. O. F. & $-4,8$ & 1,4 & 0,5 & 0,0 & 6,9 & 5,1 \\
\hline 21 - M. L.P. & $-3,0$ & 2,0 & $-0,2$ & 0,0 & $-2,7$ & $-2,2$ \\
\hline 22- M. M. S. & 9,8 & 2,0 & 1,2 & 1,0 & $-1,7$ & $-2,6$ \\
\hline 23- N. C. R. & 4,6 & 1,1 & 0,7 & 0,0 & $-0,6$ & 0,3 \\
\hline 24- P. S. D. & 2,3 & 1,2 & 0,5 & 0,9 & 2,5 & 1,8 \\
\hline 25- R. M. G. & 8,4 & 5,8 & 0,6 & 0,8 & $-5,7$ & $-2,4$ \\
\hline 26- R. C. M. & 2,7 & 2,1 & 1,6 & 1,8 & $-4,1$ & 0,5 \\
\hline 27- R. D. P. & 10,5 & 1,3 & $-0,1$ & 0,6 & $-6,4$ & $-3,4$ \\
\hline 28- S. F. A. & $-4,7$ & $-1,5$ & $-0,8$ & $-0,9$ & $-2,2$ & 0,4 \\
\hline 29- S. A. P. & $-3,3$ & $-2,0$ & 0,5 & 0,1 & 1,1 & 2,7 \\
\hline 30- W. R. C. & 19,0 & 6,1 & 0,8 & 1,6 & $-7,2$ & $-3,7$ \\
\hline
\end{tabular}


Tabela A - 28

\begin{tabular}{|c|c|c|c|c|c|c|}
\hline \multirow[b]{2}{*}{ Paciente } & \multicolumn{5}{|c|}{ CLASSE II, SUBDIVISÃO NÃO TRATADO } & \multirow[b]{2}{*}{ LMDI-EIMI } \\
\hline & LMDS-EIPTM & LMM-EIPTM & LMDI-EIPTM & PDMI-PCM & PDMS-PCM & \\
\hline 1- A. B. & $-0,1$ & $-2,5$ & $-2,5$ & 4,6 & 0,7 & 0,9 \\
\hline 2- A. E. & 2,9 & 1,4 & 0,8 & 4,1 & $-2,1$ & 2,0 \\
\hline 3- A. N. P. M. & $-3,2$ & $-9,0$ & $-6,9$ & 4,8 & 1,2 & $-1,5$ \\
\hline 4- A. L. G. S. & $-0,4$ & $-0,5$ & $-2,8$ & 3,6 & 1,7 & $-0,2$ \\
\hline 5- A.P.F.R. & 0,3 & $-2,1$ & $-1,3$ & 3,2 & 0,1 & 0,8 \\
\hline 6- A. G. & $-3,6$ & $-5,7$ & $-4,5$ & 7,6 & 4,8 & 1,5 \\
\hline 7- A. C. M. Jr. & $-0,9$ & $-2,1$ & $-1,6$ & 2,7 & $-3,2$ & 1,4 \\
\hline 8- B. P. L. & 2,4 & $-0,1$ & 0,2 & 2,6 & $-0,2$ & 0,0 \\
\hline 9- C. Q. & 1,2 & 0,8 & 1,4 & 2,0 & $-2,2$ & 1,5 \\
\hline 10- C.B.S. & 2,7 & 1,4 & 1,0 & 3,9 & 0,0 & 3,4 \\
\hline 11- C. A. A. & 2,8 & 2,2 & $-0,1$ & 1,5 & $-1,8$ & 0,5 \\
\hline 12- D. F.R. S. & $-2,1$ & $-2,1$ & $-3,7$ & 4,3 & $-2,1$ & 1,7 \\
\hline 13- D. M. B. & 1,5 & $-1,9$ & $-0,6$ & 0,8 & $-2,0$ & 0,2 \\
\hline 14- D. M R. & 1,9 & $-3,1$ & $-1,7$ & 4,8 & 1,3 & $-0,2$ \\
\hline 15- E. Y.Y. & 0,4 & $-5,3$ & $-1,8$ & 2,4 & $-1,0$ & 2,7 \\
\hline 16- E.P. & 0,0 & $-2,7$ & $-2,2$ & 3,2 & 0,9 & 0,7 \\
\hline 17- F.S.S. & 3,1 & 2,5 & 1,6 & $-0,9$ & $-3,1$ & 0,2 \\
\hline 18- I. A. & $-0,8$ & $-0,6$ & $-1,5$ & $-0,1$ & $-3,4$ & 1,4 \\
\hline 19- L. C. C. S. & 0,4 & 0,9 & $-1,9$ & $-0,5$ & $-5,8$ & 2,0 \\
\hline 20- M. A. O. F. & 3,1 & 2,6 & 1,2 & $-0,1$ & $-3,1$ & 1,2 \\
\hline 21- M. L.P. & 0,9 & $-0,8$ & $-1,8$ & 5,5 & 1,2 & 0,9 \\
\hline 22- M. M. S. & $-1,5$ & $-2,9$ & $-2,4$ & 2,5 & 0,2 & $-0,2$ \\
\hline 23- N. C. R. & 2,3 & 0,8 & $-0,5$ & $-0,5$ & $-3,8$ & 1,1 \\
\hline 24- P. S. D. & 1,2 & 0,4 & $-1,3$ & 2,3 & $-2,9$ & 0,7 \\
\hline 25- R. M. G. & $-1,4$ & $-1,6$ & $-2,6$ & 2,9 & $-1,1$ & 1,2 \\
\hline 26- R. C. M. & 1,0 & $-1,7$ & $-0,8$ & 2,8 & $-2,3$ & 2,2 \\
\hline 27- R. D. P. & $-2,7$ & $-1,8$ & $-6,5$ & 7,2 & $-0,6$ & 2,3 \\
\hline 28- S. F. A. & 0,6 & $-2,8$ & $-2,7$ & 3,3 & $-2,9$ & 1,3 \\
\hline 29- S. A. P. & 2,2 & 0,3 & 0,4 & 0,4 & $-1,1$ & 0,3 \\
\hline 30- W. R. C. & $-4,9$ & $-9,9$ & $-6,2$ & 10,7 & 5,5 & 1,4 \\
\hline
\end{tabular}

Tabela A - 29

\begin{tabular}{|c|c|c|c|c|c|c|}
\hline & & CLASSE II, SL & IVISÃO NÃO & ATADO & & \\
\hline Paciente & LMM-EIMI & LMDS-EIMI & LMDI-EIMS & LMDS-EIMS & LMM-EIMS & EIE.EIC \\
\hline 1- A. B. & 0,8 & 3,8 & $-3,1$ & $-0,7$ & $-3,1$ & $-1,2$ \\
\hline 2- A. E. & 2,4 & 4,6 & $-3,5$ & $-1,5$ & $-2,9$ & 0,4 \\
\hline 3- A. N. P. M. & $-3,2$ & 2,4 & $-4,8$ & $-1,2$ & $-6,9$ & 0,9 \\
\hline 4- A. L. G. S. & 2,6 & 2,7 & $-1,6$ & 1,1 & 1,0 & 0,4 \\
\hline 5- A. P. F. R. & 0,0 & 2,5 & $-0,4$ & 1,1 & $-1,2$ & 0,2 \\
\hline 6- A. G. & 0,8 & 2,6 & $-0,7$ & 0,3 & $-1,7$ & $-1,0$ \\
\hline 7- A. C. M. Jr. & 0,7 & 2,6 & $-3,1$ & $-2,3$ & $-3,5$ & 3,4 \\
\hline 8- B. P. L. & $-0,1$ & 2,2 & $-2,4$ & $-0,4$ & $-2,4$ & 0,0 \\
\hline 9- C. Q. & 0,9 & 1,5 & $-2,0$ & $-2,5$ & $-2,5$ & $-0,2$ \\
\hline 10- C. B. S. & 3,4 & 6,0 & 0,4 & 2,5 & 0,6 & 0,2 \\
\hline 11- C. A. A. & 3,1 & 3,7 & $-2,4$ & 0,5 & $-0,1$ & 0,4 \\
\hline 12- D. F.R.S. & 3,8 & 3,8 & $-4,1$ & $-2,4$ & $-2,4$ & 1,2 \\
\hline 13- D. M. B. & $-1,0$ & 2,1 & $-1,8$ & $-0,2$ & $-3,0$ & $-0,2$ \\
\hline 14- D. M R. & $-1,6$ & 3,3 & $-3,4$ & $-0,4$ & $-5,1$ & $-0,8$ \\
\hline 15- E. Y. Y. & $-0,4$ & 5,1 & $-0,7$ & 1,5 & $-4,2$ & 0,7 \\
\hline 16- E.P. & 0,1 & 3,2 & $-1,3$ & 0,9 & $-1,9$ & 1,3 \\
\hline 17- F. S. S. & 1,2 & 1,8 & $-1,0$ & 0,5 & $-0,1$ & 0,3 \\
\hline 18- I. A. & 2,3 & 3,1 & $-1,6$ & $-0,7$ & $-0,7$ & $-1,1$ \\
\hline 19- L. C. C. S. & 4,6 & 5,2 & $-3,0$ & $-0,5$ & $-0,2$ & 0,9 \\
\hline 20- M. A. O. F. & 2,3 & 3,4 & $-2,4$ & $-0,7$ & $-0,9$ & 0,7 \\
\hline 21 - M. L.P. & 1,7 & 4,0 & $-2,3$ & 0,1 & $-1,1$ & 0,8 \\
\hline 22- M. M. S. & $-0,7$ & 0,8 & $-1,8$ & $-0,9$ & $-2,2$ & 0,7 \\
\hline 23- N. C. R. & 2,2 & 4,0 & $-2,1$ & 0,5 & $-0,7$ & 2,1 \\
\hline 24- P. S. D. & 2,0 & 3,5 & $-3,3$ & $-1,0$ & $-1,6$ & $-0,2$ \\
\hline 25- R. M. G. & 2,2 & 2,5 & $-2,5$ & $-1,4$ & $-1,4$ & $-0,7$ \\
\hline 26- R. C. M. & 1,5 & 4,1 & $-2,9$ & $-1,4$ & $-4,3$ & 0,2 \\
\hline 27- R. D. P. & 6,7 & 7,4 & $-3,9$ & 0,2 & 0,8 & $-2,1$ \\
\hline 28- S. F. A. & 1,1 & 5,3 & $-3,1$ & 0,1 & $-3,3$ & 0,7 \\
\hline 29- S. A.P. & 0,2 & 2,2 & $-1,0$ & 0,9 & $-1,0$ & 0,2 \\
\hline 30- W. R. C. & $-3,7$ & 3,7 & $-2,7$ & $-1,0$ & $-7,0$ & $-1,2$ \\
\hline
\end{tabular}


Tabela A - 30

\begin{tabular}{|c|c|c|c|c|c|c|}
\hline & & ASSE II, & ISÃO NẤ & TADO & & \\
\hline Paciente & ETE.ETC & $\begin{array}{c}\text { ETPTM. } \\
\text { ETC }\end{array}$ & $\begin{array}{c}\text { ETPTM. } \\
\text { ETE }\end{array}$ & ETMI.ETE & ETMI.ETC & $\begin{array}{l}\text { ETMI. } \\
\text { ETPTM }\end{array}$ \\
\hline 1- A. B. & $-1,3$ & $-1,2$ & 0,1 & $-3,5$ & $-4,8$ & $-3,6$ \\
\hline 2- A. E. & 0,3 & $-0,5$ & $-0,7$ & $-5,5$ & $-5,2$ & $-4,7$ \\
\hline 3- A. N. P. M. & 1,0 & 0,4 & $-0,6$ & $-3,0$ & $-2,0$ & $-2,3$ \\
\hline 4- A. L. G. S. & 0,6 & $-0,1$ & $-0,7$ & $-5,1$ & $-4,5$ & $-4,4$ \\
\hline 5- A.P. F. R. & 0,4 & $-0,5$ & $-0,9$ & $-2,8$ & $-2,4$ & $-1,9$ \\
\hline 6- A. G. & $-0,7$ & $-1,2$ & $-0,5$ & $-4,6$ & $-5,3$ & $-4,1$ \\
\hline 7- A. C. M. Jr. & 3,6 & 3,5 & $-0,1$ & $-6,8$ & $-3,2$ & $-6,6$ \\
\hline 8- B. P. L. & $-0,1$ & $-0,6$ & $-0,5$ & 0,0 & $-0,1$ & 0,5 \\
\hline 9- C. Q. & $-0,1$ & $-0,5$ & $-0,4$ & $-2,7$ & $-2,8$ & $-2,3$ \\
\hline 10- C. B. S. & $-0,2$ & 1,5 & 1,7 & $-3,9$ & $-4,1$ & $-5,6$ \\
\hline 11- C. A. A. & 0,4 & 2,2 & 1,8 & $-2,4$ & $-2,0$ & $-4,2$ \\
\hline 12- D. F. R. S. & 1,3 & 1,6 & 0,3 & $-4,6$ & $-3,3$ & $-5,0$ \\
\hline 13- D. M. B. & $-0,1$ & $-1,7$ & $-1,6$ & $-0,1$ & $-0,2$ & 1,5 \\
\hline 14- D. M R. & $-1,1$ & $-2,5$ & $-1,3$ & $-0,6$ & $-1,7$ & 0,8 \\
\hline 15- E. Y. Y. & 1,0 & 1,5 & 0,4 & $-2,4$ & $-1,4$ & $-2,8$ \\
\hline 16- E.P. & 1,5 & 0,0 & $-1,5$ & $-3,9$ & $-2,4$ & $-2,3$ \\
\hline 17- F. S. S. & 0,3 & 0,5 & 0,1 & $-1,9$ & $-1,6$ & $-2,0$ \\
\hline 18-I. A. & $-1,0$ & 0,1 & 1,1 & $-3,0$ & $-4,0$ & $-4,1$ \\
\hline 19- L. C. C. S. & 0,9 & 2,7 & 1,8 & $-4,7$ & $-3,7$ & $-6,4$ \\
\hline 20- M. A. O. F. & 0,5 & 0,6 & 0,1 & $-3,8$ & $-3,3$ & $-3,9$ \\
\hline 21- M. L. P. & 1,2 & $-1,6$ & $-2,8$ & $-4,6$ & $-3,4$ & $-1,9$ \\
\hline 22- M. M. S. & 0,7 & 1,0 & 0,3 & $-0,8$ & $-0,1$ & $-1,1$ \\
\hline 23- N. C. R. & 2,4 & 2,4 & $-0,1$ & $-2,0$ & 0,5 & $-1,9$ \\
\hline 24- P. S. D. & $-0,3$ & 1,9 & 2,1 & $-2,6$ & $-2,8$ & $-4,7$ \\
\hline 25- R. M. G. & $-0,3$ & 1,2 & 1,5 & $-0,9$ & $-1,2$ & $-2,4$ \\
\hline 26- R. C. M. & 0,2 & $-0,7$ & $-0,8$ & $-1,8$ & $-1,7$ & $-1,0$ \\
\hline 27- R. D. P. & $-1,9$ & 3,1 & 5,0 & $-3,1$ & $-5,0$ & $-8,1$ \\
\hline 28- S. F. A. & 0,9 & 0,7 & $-0,2$ & $-4,7$ & $-3,8$ & $-4,5$ \\
\hline 29- S. A. P. & 0,6 & $-0,2$ & $-0,8$ & $-1,7$ & $-1,1$ & $-0,9$ \\
\hline 30- W. R. C. & $-0,8$ & $-1,3$ & $-0,5$ & $-3,5$ & $-4,2$ & $-3,0$ \\
\hline
\end{tabular}

Tabela A - 31

\begin{tabular}{|c|c|c|c|c|c|c|c|}
\hline & & LASSE II, SU & IISÃO NÃ & ATADO & & & \\
\hline Paciente & ETMS.ETE & ETMS.ETC & $\begin{array}{l}\text { ETMS. } \\
\text { ETPTM }\end{array}$ & $\begin{array}{l}\text { PCM- } \\
\text { LMM }\end{array}$ & РCM-CMM & POSM & POSMS \\
\hline 1- A. B. & $-0,1$ & $-1,4$ & $-0,2$ & 3,3 & $-0,7$ & $-1,2$ & 0,1 \\
\hline 2- A. E. & 0,0 & 0,3 & 0,8 & 0,9 & $-3,2$ & $-1,5$ & $-1,4$ \\
\hline 3- A. N. P. M. & $-0,2$ & 0,8 & 0,5 & 8,4 & 1,1 & $-0,7$ & $-1,6$ \\
\hline 4- A. L. G. S. & $-3,2$ & $-2,5$ & $-2,4$ & 0,7 & 0,3 & $-0,4$ & 1,4 \\
\hline 5- A. P. F. R. & 0,9 & 1,3 & 1,8 & 3,0 & 3,4 & $-0,3$ & 0,4 \\
\hline 6- A. G. & $-1,6$ & $-2,3$ & $-1,1$ & 6,5 & 0,2 & $-3,8$ & $-1,6$ \\
\hline 7- A. C. M. Jr. & $-0,4$ & 3,1 & $-0,3$ & 1,0 & 4,8 & $-3,6$ & $-3,0$ \\
\hline 8- B. P. L. & 1,4 & 1,3 & 1,9 & 3,4 & 4,2 & $-0,6$ & 1,1 \\
\hline 9- C. Q. & 1,5 & 1,3 & 1,8 & 0,3 & 3,6 & $-2,2$ & 0,9 \\
\hline 10- C. B. S. & -0.6 & -0.8 & $-2,3$ & -1.0 & $-0,9$ & 1,2 & 0,9 \\
\hline 11- C. A. A. & 0,4 & 0,8 & $-1,4$ & $-1,4$ & $-1,3$ & 2,4 & 2,9 \\
\hline 12- D. F.R.S. & $-0,2$ & 1,1 & $-0,5$ & 0,3 & 4,0 & 2.7 & 2,3 \\
\hline 13- D. M. B. & 2,4 & 2,3 & 4,0 & 2,1 & 3,7 & $-0,6$ & $-1,2$ \\
\hline 14- D. M R. & 2.7 & 1.5 & 4.0 & 7,2 & 3,4 & $-3,3$ & -1.8 \\
\hline 15- E. Y.Y. & $-0,4$ & 0,6 & $-0,9$ & 3,4 & 0,7 & $-4,1$ & $-4,4$ \\
\hline 16- E.P. & $-1,9$ & $-0,4$ & $-0,3$ & 3,0 & 0,6 & $-1,7$ & $-1,5$ \\
\hline 17- F.S.S. & 0,8 & 1,1 & 0,7 & $-3,1$ & $-0,3$ & $-0,3$ & 0,5 \\
\hline 18- I. A. & 1,1 & 0,1 & 0,1 & $-3,0$ & $-1,8$ & 0,7 & 1,2 \\
\hline 19- L. C. C. S. & 1,5 & 2,4 & $-0,3$ & $-6,2$ & $-0,1$ & 3,4 & 5,8 \\
\hline 20- M. A. O. F. & 1,2 & 1,7 & 1,1 & $-2,2$ & 1,1 & $-0,6$ & 2,4 \\
\hline 21 - M. L. P. & $-0,3$ & 0,9 & 2,5 & 3,4 & 2,5 & $-1,0$ & 0,7 \\
\hline 22- M. M. S. & 2,5 & 3,2 & 2,2 & 4,0 & 6,0 & 0,2 & 0,9 \\
\hline 23- N. C. R. & 1,8 & 4,2 & 1,8 & $-2,4$ & $-0,8$ & $-1,9$ & 0,3 \\
\hline 24- P. S. D. & 3,5 & 3,2 & 1,4 & $-0,2$ & 2,2 & $-1,2$ & 1,5 \\
\hline 25- R. M. G. & 2,1 & 1,8 & 0,6 & 0,3 & 7,9 & $-3,0$ & $-5,5$ \\
\hline 26- R. C. M. & 1,8 & 1,9 & 2,6 & 1,8 & 1,8 & 0,2 & $-2,3$ \\
\hline $27-$ R. D. P. & 3,6 & 1,7 & $-1,3$ & $-0,5$ & 2,2 & $-4,4$ & $-2,4$ \\
\hline 28- S. F. A. & 1,1 & 2,0 & 1,3 & 1,2 & 0,1 & $-1,3$ & $-2,6$ \\
\hline 29- S. A.P. & $-0,6$ & 0,0 & 0,2 & 0,0 & 0,9 & 0,7 & 0,9 \\
\hline 30- W. R. C. & 0,3 & $-0,5$ & 0,8 & 15,3 & 12,1 & 1,1 & 5,3 \\
\hline
\end{tabular}


Tabela A - 32

\begin{tabular}{|c|c|c|c|c|c|c|c|}
\hline & & CLASSE II, SUB & SÃO NÃO T & & & & \\
\hline Paciente & ÂPLANOZ & ÂPLOCLUSAL & ÂPLANTEG & DESVENA & DESMAND & A1 & B1 \\
\hline 1- A. B. & 89,5 & 90,2 & 90,4 & 1,2 & 3,2 & 0,8 & 3,4 \\
\hline 2- A.E. & 86,6 & 86,1 & 87,4 & $-3,8$ & 1,9 & $-2,3$ & 0,3 \\
\hline 3- A. N. P. M. & 91,9 & 88,9 & 87,9 & 1,5 & 8,4 & 1,6 & 5,4 \\
\hline 4- A. L. G. S. & 89,3 & 89,5 & 81,5 & $-1,4$ & $-2,9$ & $-2,2$ & 0,3 \\
\hline 5- A. P. F. R. & 92,2 & 92,8 & 93,7 & 2,4 & 1,6 & 0,2 & 2,4 \\
\hline 6- A. G. & 90,8 & 93,4 & 88,1 & 1,5 & 6,4 & 2,9 & 3,9 \\
\hline 7- A. C. M. Jr. & 88,0 & 91,2 & 87,2 & $-1,4$ & 0,0 & $-2,4$ & $-0,8$ \\
\hline 8- B. P. L. & 86,9 & 86,5 & 84,9 & $-4,1$ & $-2,6$ & $-4,0$ & $-1,8$ \\
\hline 9- C. Q. & 88,5 & 88,9 & 88,9 & $-1,2$ & 0,4 & $-0,2$ & $-0,6$ \\
\hline 10- C. B. S. & 84,9 & 87,4 & 84,8 & $-6,4$ & $-4,2$ & $-6,2$ & $-4,4$ \\
\hline 11- C. A. A. & 90,7 & 92,7 & 90,6 & $-0,6$ & $-1,5$ & $-2,4$ & $-0,2$ \\
\hline 12- D. F. R.S. & 92,1 & 90,4 & 92,2 & 2,0 & 1,1 & 2,0 & 4,4 \\
\hline 13- D. M. B. & 93,1 & 92,3 & 91,3 & 3,1 & 6,2 & 4,3 & 5,4 \\
\hline 14- D. M R. & 88,6 & 87,8 & 84,2 & $-1,2$ & 2,6 & $-0,8$ & 2,4 \\
\hline 15- E. Y. Y. & 86,7 & 85,7 & 88,4 & $-4,5$ & 0,6 & $-3,7$ & $-1,6$ \\
\hline 16- E.P. & 91,1 & 89,2 & 90,3 & 1,7 & 3,7 & 1,0 & 2,9 \\
\hline 17- F.S.S. & 92,5 & 88,5 & 91,1 & 2,7 & 7,7 & 3,1 & 4,8 \\
\hline 18- I. A. & 89,5 & 88,0 & 86,9 & 0,1 & 4,6 & 2,5 & 2,9 \\
\hline 19- L. C. C. S. & 87,7 & 90,7 & 88,6 & $-2,4$ & $-2,6$ & $-4,2$ & $-2,1$ \\
\hline 20- M. A. O. F. & 89,5 & 87,7 & 86,0 & $-1,6$ & 0,8 & $-1,6$ & 0,6 \\
\hline 21- M. L.P. & 89,9 & 90,5 & 88,4 & 0,6 & 6,2 & 2,1 & 4,7 \\
\hline 22- M. M. S. & 90,1 & 90,1 & 88,1 & 0,0 & $-0,5$ & $-1,2$ & $-0,2$ \\
\hline 23- N. C. R. & 88,6 & 92,5 & 89,6 & $-1,0$ & 1,6 & $-1,5$ & 1,3 \\
\hline 24- P. S. D. & 90,2 & 93,8 & 89,4 & $-0,4$ & $-2,2$ & $-2,9$ & 0,0 \\
\hline 25- R. M. G. & 89,4 & 91,0 & 89,8 & $-0,1$ & 0,4 & 0,7 & 0,8 \\
\hline 26- R. C. M. & 91,5 & 91,3 & 88,9 & 0,6 & 1,6 & 0,8 & 1,5 \\
\hline 27- R. D. P. & 91,5 & 90,2 & 89,5 & 1,4 & 4,5 & 1,4 & 6,1 \\
\hline 28- S. F. A. & 90,1 & 88,4 & 88,2 & $-0,3$ & 3,9 & $-0,7$ & 2,6 \\
\hline 29- S. A.P. & 90,7 & 90,7 & 88,7 & 1,9 & 4,7 & 1,5 & 2,4 \\
\hline 30- W. R. C. & 88,7 & 88,8 & 89,1 & $-0,1$ & 4,5 & 0,9 & 2,2 \\
\hline
\end{tabular}

Tabela A - 33

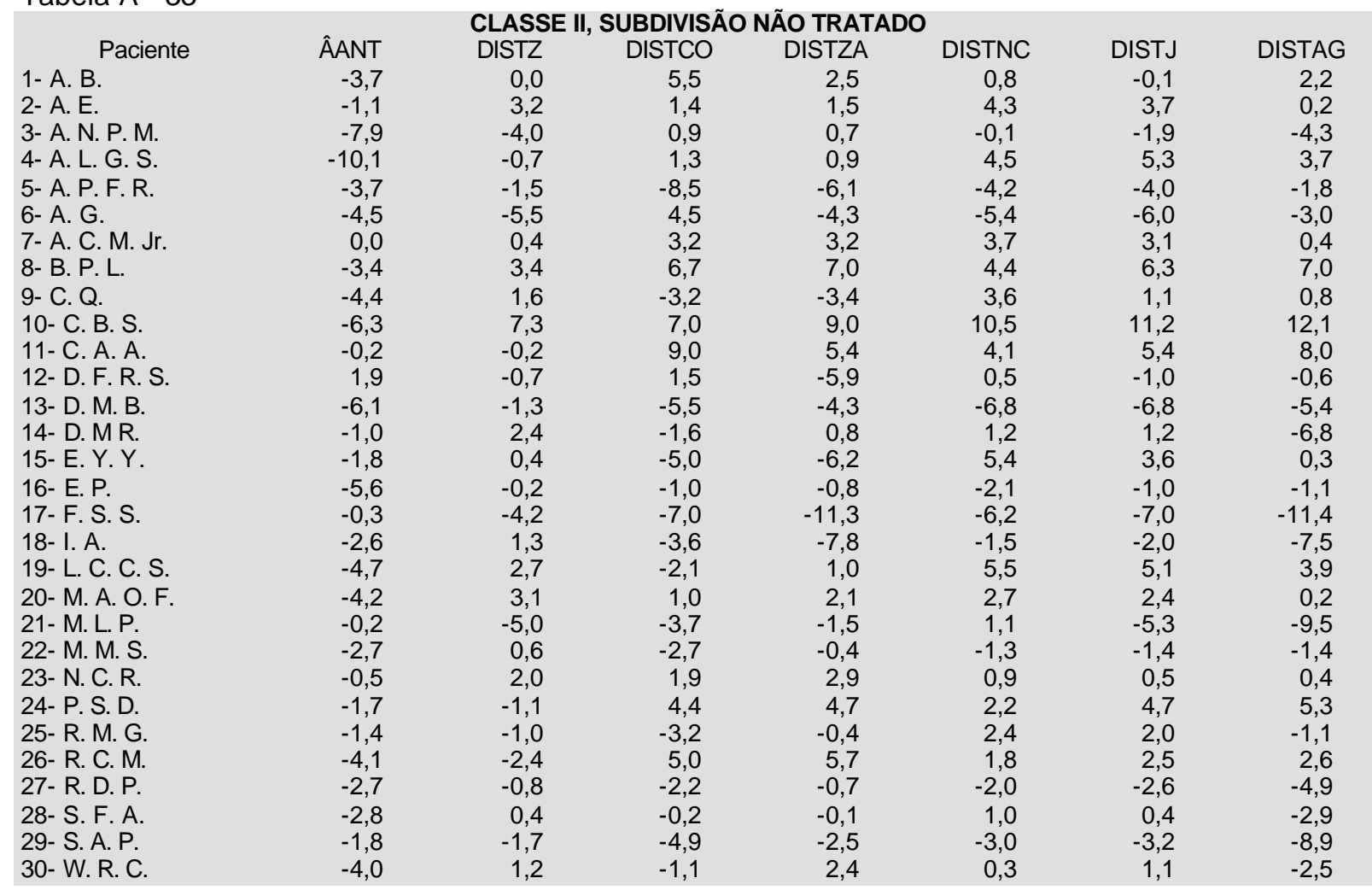


Tabela A - 34

\begin{tabular}{lc}
\multicolumn{1}{l}{ Paciente } & ALT6 \\
1- A. B. & $-1,8$ \\
2- A. E. & $-1,5$ \\
3- A. N. P. M. & 0,4 \\
4- A. L. G. S. & $-1,0$ \\
5- A. P. F. R. & $-0,9$ \\
6- A. G. & $-4,1$ \\
7- A. C. M. Jr. & $-1,1$ \\
8- B. P. L. & $-1,6$ \\
9- C. Q. & $-3,5$ \\
10- C. B. S. & $-0,2$ \\
11- C. A. A. & $-1,6$ \\
12- D. F. R. S. & 1,9 \\
13- D. M. B. & $-0,4$ \\
14- D. M R. & 2,0 \\
15- E. Y. Y. & $-1,0$ \\
16- E. P. & 0,6 \\
17- F. S. S. & 1,4 \\
18- I. A. & $-0,5$ \\
19- L. C. C. S. & $-5,7$ \\
20- M. A. O. F. & $-1,8$ \\
21- M. L.P. & $-3,1$ \\
22- M. M. S. & $-1,9$ \\
23- N. C. R. & $-6,8$ \\
24- P. S. D. & $-0,6$ \\
25- R. M. G. & $-2,0$ \\
26- R. C. M. & $-0,4$ \\
27- R. D. P. & $-0,4$ \\
28- S. F. A. & $-1,0$ \\
29- S. A.P. & $-1,0$ \\
30- W. R. C. & $-1,4$ \\
- &
\end{tabular}

CLASSE II, SUBDIVISÃO NÃO TRATADO

$\begin{array}{ccc}\text { CO-AG } & \text { CO-ME } & \text { ME-AG } \\ 4,9 & 8,9 & 6,1 \\ 2,2 & 4,8 & 3,7 \\ 4,3 & 6,2 & 5,5 \\ 12,8 & -1,2 & -9,8 \\ -2,5 & -1,8 & 2,4 \\ 4,7 & 6,1 & 4,5 \\ 4,2 & 2,8 & -1,2 \\ 1,1 & -0,7 & -0,4 \\ -1,6 & -2,2 & 1,3 \\ 0,9 & 0,1 & 2,5 \\ -3,9 & 0,7 & 5,2 \\ -5,6 & -2,5 & 2,0 \\ -1,2 & 0,3 & 3,8 \\ 7,6 & 0,6 & -6,5 \\ -1,7 & 0,2 & 3,1 \\ 0,7 & 1,6 & 3,5 \\ -1,2 & 0,5 & 2,0 \\ 4,8 & 1,8 & -1,9 \\ 6,1 & 3,6 & -0,3 \\ 1,1 & -1,6 & -0,8 \\ 0,6 & 0,5 & 0,0 \\ 5,0 & 0,2 & -3,6 \\ -0,1 & 2,7 & 3,3 \\ 2,1 & 1,6 & 0,5 \\ -1,7 & -2,5 & -0,4 \\ 3,3 & 3,9 & 2,9 \\ 5,3 & 5,2 & 1,5 \\ 2,1 & 3,1 & 2,7 \\ 1,4 & -1,0 & -1,8 \\ 4,8 & 6,4 & 3,9\end{array}$

